\author{
UNIVERSIDADE DE SÃO PAULO \\ FACULDADE DE ZOOTECNIA E ENGENHARIA DE ALIMENTOS
}

MONALISA MEDRADO BOMFIM

Efeitos do estresse oxidativo durante a produção in vitro de embriões bovinos sobre o miR-199a e genes alvo ERBB2 e ERBB3 
MONALISA MEDRADO BOMFIM

Efeitos do estresse oxidativo durante a produção in vitro de embriões bovinos sobre o miR-199a e genes alvo ERBB2 e ERBB3

Versão Corrigida

Dissertação apresentada à Faculdade de Zootecnia e Engenharia de Alimentos da Universidade de São Paulo, como parte dos requisitos para obtenção do título de Mestre em Ciência do Programa de pós-graduação de Biociência Animal.

Área de Concentração: Ciências da Medicina Veterinária

Orientador: Prof. Dr. Felipe Perecin 
Ficha catalográfica elaborada pelo Serviço de Biblioteca e Informação, FZEA/USP, com os dados fornecidos pelo(a) autor(a)

Bomfim, Monalisa Medrado Efeitos do estresse oxidativo durante a produção in vitro de embriões bovinos sobre o miR-199a e genes alvo ERBB2 e ERBB3 / Monalisa Medrado Bomfim ; orientador Felipe Perecin. -- Pirassununga, 2017. $160 \mathrm{f}$.

Dissertação (Mestrado - Programa de Pós-Graduação em Biociência Animal) -- Faculdade de Zootecnia e Engenharia de Alimentos, Universidade de São Paulo.

1. BIOLOGIA DO DESENVOLVIMENTO. 2. EMBRIOLOGIA MOLECULAR. 3. miRNAs . 4. EPIGENÉTICA • 5. ESTRESSE OXIDATIVO. I. Perecin, Felipe, orient. II. Título. 


\section{Efeitos do estresse oxidativo durante a produção in vitro de embriões bovinos sobre o miR-199a e genes alvo ERBB2 e ERBB3}

Dissertação apresentada à Faculdade de Zootecnia e Engenharia de Alimentos da Universidade de São Paulo, como parte dos requisitos para obtenção do título de Mestre em Ciência do Programa de pós-graduação de Biociência Animal.

Área de Concentração: Ciências da Medicina Veterinária

Data de aprovação: $\underline{07} / \underline{04} / \underline{2017}$

Banca Examinadora:

Prof. Dr. Felipe Perecin - Presidente da Banca Examinadora

Faculdade de Zootecnia e Engenharia de Alimentos - USP

Prof. Dr.a Claúdia Lima Verde Leal

Faculdade de Zootecnia e Engenharia de Alimentos - USP

Prof. Dr.a Marcella Pecora Milazzotto

Universidade Federal do ABC

Prof. Dr. Marcelo Fabio Gouveia Nogueira

Faculdade de Ciências e Letras de Assis - UNESP 


\section{AGRADECIMENTOS}

Agradeço ao Prof. Dr. Felipe Perecin pela orientação, confiança e paciência que permitiram a realização desse trabalho. Ao Dr. Juliano Coelho da Silveira pela co-orientação não oficial que contribuiu muito para a pesquisa. Aos colegas de laboratório Gabriela Mamede, Juliano Sangalli e Maite Del Collado pela ajuda diária nas atividades do laboratório. Às alunas de iniciação científica Letícia Rebello, Rosane Mazzarella e Bruna Pavan que sempre estavam à disposição para ajudar. À Patrícia Kubo Fontes, ao Prof. Marcelo Nogueira e ao Laboratório de Fitomedicamentos Farmacologia e Biotecnologia (FitoFarmaTec) pela realização dos ensaios de expressão gênica utilizando o Biomark HD.

Gostaria de agradecer também à Fundação de Amparo à Pesquisa do Estado de São Paulo (FAPESP) pelo suporte financeiro da bolsa de mestrado (processo 2014/21042-6) e pelo acesso ao equipamento multiusuário Nanosight NS300 (processo 2015/21829-9); ao Matadouro Frigorífico Olhos D'água pela doação dos ovários; à CRV Lagoa pela doação das paletas de sêmen necessárias ao desenvolvimento deste trabalho; e aos Laboratório de Oncologia Comparada e Translacional (LOCT - da FZEA/USP) e Laboratório Multiusuário Microscopia Confocal (LMMC - da FMRP/USP) pelo uso respectivamente dos microscópios de epifluorescência (FAPESP 2014/02493-7) e confocal. 


\section{RESUMO}

A produção in vitro de embriões expõe o concepto a condições diferentes do ambiente intra-tubárico-uterino. A alta tensão de oxigênio durante o cultivo in vitro induz estresse oxidativo mediante aumento dos níveis das espécies reativas de oxigênio. A condição de estresse oxidativo altera a expressão de RNAm e miRNAs, podendo comprometer vias de interação materno-embrionária. Recentemente, os exossomos têm sido descritos como um mecanismo complementar de transporte de RNAm e miRNAs, que beneficiam a comunicação bidirecional materno-embrionária. Portanto, além do estudo dos próprios embriões, a análise dos exossomos isolados do meio de cultivo da PIVE também é relevante. Comumente são utilizados dois modelos de cultivo na PIVE, a alta tensão (20\%) e a baixa tensão (5\%) de oxigênio. A hipótese deste estudo é que a alta tensão de oxigênio no cultivo embrionário gera uma condição de estresse oxidativo que causa alterações de expressão de RNAm e miRNAs presentes nos embriões e nos exossomos. Além disso, o estresse oxidativo exerceria efeito sobre o padrão de secreção destes exossomos. Para testar essa hipótese este estudo produziu embriões bovinos in vitro cultivados em diferentes tensões de oxigênio. Os embriões foram coletados no dia 7 e os meios de cultivo, para isolamento os exossomos, foram coletados nos dias 3 e 7 do cultivo. Os blastocistos cultivados em alta tensão de oxigênio apresentaram um aumentou dos níveis de EROs através de análise de fluorescência. Este resultado validou o modelo de estresse oxidativo para embriões. Os resultados iniciais indicaram que apesar do miR-199a-5p, descrito como possível regulador dos genes alvos ERBB2 e ERBB3, ter apresentado maior expressão nos embriões cultivados em alta tensão, os transcritos ERBB2 e ERBB3 e a proteína ERBB2 não apresentaram diferença significativa entre os grupos. Uma vez que não se estabeleceu uma relação de regulação entre o miR-199a-5p e o gene alvo ERBB2 para os embriões bovinos, este estudo se voltou para a análise de outros 96 RNAm e 378 miRNAs, destes 40 RNAm e 8 miRNAs apresentaram alterações significativas entre os embriões cultivados em alta e baixa tensão de oxigênio. Entre as principais funções alteradas estão associadas à resposta ao estresse oxidativo, proliferação e diferenciação celular, remodelação epigenética, apoptose, metabolismo e reconhecimento materno-fetal. Por fim, com o objetivo de compreender um panorama maior dos efeitos do estresse oxidativo, este estudo se propôs a analisar o padrão de expressão e os miRNAs do conteúdo dos exossomos do meio de cultivo. O estresse 
oxidativo alterou tanto a concentração dos exossomos quanto a expressão dos mRNAs, em ambos os dias do desenvolvimento embrionário (D3 e D7). Dentre os miRNAs, destaca-se o miR-210 que foi considerado por este trabalho como biomarcador não invasivo da condição de normoxia no cultivo in vitro de embriões bovinos. Em conclusão, esse estudo não elucidou como o estresse oxidativo altera a interação materno-embrionária em embriões produzidos in vitro em diferentes condições de tensão de oxigênio, mas gerou conhecimentos adicionais sobre do desenvolvimento embrionário bovino e os efeitos da alta tensão de oxigênio.

Palavras chave: miRNAs, EROs, metilação, desenvolvimento embrionário. 


\section{ABSTRACT}

The in vitro embryo production exposes the concept to conditions different from the intra-tubal-uterine environment. The high oxygen tension during in vitro production induces the oxidative stress by increasing the concentration of reactive oxygen species. The oxidative stress condition changes the mRNA and miRNAs expression, it can compromise pathways of maternal-embryonic interaction. Recently, the exosomes have been described as a complementary mechanism of mRNA and miRNAs transport, which improve the bidirectional maternal-embryonic communication. Therefore, the studies of the embryos and exosomes isolated from the IVP culture medium are relevant. Two cultivation models are usually used in IVP, the high tension (20\%) and the low tension (5\%) of oxygen. The hypothesis of this study is that the high oxygen tension in the embryonic culture generates an oxidative stress condition that causes changes in the mRNA and miRNAs expression. In addition, this oxidative stress is able to modulate the secretion pattern of the exosomes isolated from IVP embryos. To test this hypothesis, this study produced in vitro bovine embryos developed at different oxygen tensions. The embryos were sampled on day 7 and the culture media, for exosomes isolation, were collected on days 3 and 7 of the embryo development. Blastocysts cultured in high oxygen tension showed increased levels of ROS through fluorescence analysis. This result validated the oxidative stress model for embryos. In order to understand the effect of oxidative stress on the pathways of maternal-embryonic interaction, this study aimed to analyze the ERBB signaling pathway. Despite the fact that miR-199a-5p, described as a possible regulator of the ERBB2 and ERBB3 target genes, showed higher expression in embryos cultured under high tension, the ERBB2 and ERBB3 transcripts and the ERBB2 protein showed no significant difference between high and low oxygen tension groups. Since a regulatory relationship between miR-199a-5p and the ERBB2 target gene was not established for bovine embryos, this study turned to the analysis of other 96 mRNAs and 378 miRNAs, out of 40 mRNAs and 8 miRNAs showed significant changes among the groups. The main altered functions are the response to oxidative stress, cell proliferation and differentiation, epigenetic remodeling, apoptosis, metabolism and maternal-fetal recognition. Finally, in order to understand the bigger picture of oxidative stress effect we analyze the secretion pattern and the miRNA content of the exosomes from culture medium of IVP embryos. Oxidative stress change both, the exosome concentration 
and the miRNA expression (at D3 and D7). Among the miRNAs, we highlight the miR-210 that was considered by this work as a non-invasive biomarker of the normoxia condition in the in vitro culture of bovine embryos. In conclusion, this study did not elucidate how oxidative stress changes the maternal-embryonic interaction in IVP embryos, but it generated additional knowledge about bovine embryonic development and the high oxygen tension effects.

Keywords: miRNAs, ROS, methylation, embryo development. 


\section{LISTA DE FIGURAS}

Figura 1. Esquema ilustrativo da reprogramação embrionária que ocorre durante o desenvolvimento embrionário inicial. A reprogramação embrionária envolve, principalmente, dois eventos: reprogramação epigenética, através das ondas de desmetilação e metilação "de novo"; e a transição materno-embrionária, com a depleção gradual dos transcritos e proteínas maternos, concomitante com a crescente produção de transcritos do embrião (ativação do genoma embrionário). A ativação completa do genoma do embrião, em bovinos, ocorre entre os estágios de 8 e 16 células, próximo ao dia 4 do desenvolvimento embrionário.

Figura 2. Esquema ilustrativo do metabolismo de cisteína no complexo cumulus oócito, durante a suplementação do meio de maturação do oócito com cisteína e cisteamina. $\mathrm{COC}=$ Complexo cumulus oócito; GSH = Glutationa.

Figura 3. Esquema da transmissão de sinal da via ERBB.

Figura 4. Delineamento do Experimento I. Os embriões foram cultivados em diferentes tensões de $\mathrm{O}_{2}$ (alta $20 \% \mathrm{O}_{2}$ e baixa $5 \% \mathrm{O}_{2}$ ), posteriormente foram desenvolvidos dois grupos adicionais cultivado em alta tensão de oxigênio na presença e ausência de suplementado com antioxidantes. As coletas dos blastocistos foram realizadas no dia 7 do desenvolvimento. As análises foram realizadas com pools de embriões otimizados para cada técnica, com no mínimo três repetições biológicas.

Figura 5. Delineamento do experimento do Experimento II. Os embriões foram cultivados em diferentes tensões de $\mathrm{O}_{2}$ (alta - $20 \% \mathrm{O}_{2}$; e baixa - $5 \% \mathrm{O}_{2}$ ), posteriormente foram desenvolvidos dois grupos adicionais cultivado em alta tensão de oxigênio na presença e ausência de suplementado com antioxidantes. As coletas dos blastocistos foram realizadas no dia 7 do desenvolvimento. As análises foram realizadas com pools de embriões otimizados para cada técnica, com no mínimo três repetições biológicas.

Figura 6. Delineamento do Experimento III. Os embriões produzidos em Alta $\mathrm{O}_{2}$ e Baixo $\mathrm{O}_{2}$ no Experimento I tiveram os meios de cultivo coletados no D3, durante o procedimento de feeding, e em D7. As amostras foram agrupadas em pools de 3 repetições para isolamento e análise dos exossomos e seu conteúdo de miRNAs. As análises estatísticas foram realizadas com 3 repetições para cada grupo

Figura 7. Os gráficos de pontos representam as curvas de eficiência dos primers para os genes candidatos ERBB2 (azul) e ERBB3 (verde), e genes endógenos PPIA (cinza) e RPL15 (verde). A equação da reta e o valor do coeficiente de determinação da regressão linear $\left(R^{2}\right)$ 
são apresentados para os respectivos genes. Nos gráficos, o eixo $\mathrm{X}$ representa o log das diluições utilizadas e o eixo y representa os valores de $C t$ encontrados nas reações de Real Time RT-PCR.

Figura 8. Resultado do sequenciamento para os transcritos ERBB2 e ERBB3. As sequências foram analisadas através do software Prime BLAST e apresentaram 100\% de homologia com os transcritos de interesse.

Figura 9. Níveis intracelulares de EROs (em unidades arbitrárias de fluorescência) em blastocistos bovinos produzidos em alta e baixa tensão de oxigênio (A). As barras do gráfico representam o erro padrão da média. Letras diferentes $(a, b)$ indicam diferença estatística significante $(p \leq 0,05)$. Fotomicrografias de epifluorescência de blastocistos produzidos em alta (B) e baixa (C) tensões de oxigênio e corados com CellROX Green (40x). 59

Figura 10. Expressão relativa das isoformas do miR-199a para blastocistos cultivados em alta ou em baixa tensão de oxigênio. As barras representam as médias e as barras de erros representam o erro padrão da média. Letras diferentes $(a, b)$ acima das barras indicam diferença significativa $(p \leq 0,05)$. 60

Figura 11. Expressão relativa dos transcritos ERBB2 e ERBB3 para os blastocistos cultivados em alta ou em baixa tensão de oxigênio. As barras representam as médias e as barras de erros representam o erro padrão da média. Letras diferentes $(a, b)$ acima das barras indicam diferença significativa $(p \leq 0,05)$.

Figura 12. Análises da proteína ERBB2. (A) Expressão relativa e (B) imagem representativa do padrão de bandas encontradas na análise de Western Blotting para a proteína ERBB2 (185 kDa) em blastocistos bovinos cultivados em alta ou em baixa tensão de oxigênio. A expressão da proteína ERBB2 foi normalizada pela expressão da proteína beta-actina (43 kDa). As barras representam as médias e as barras de erros representam o erro padrão da média. Letras diferentes $(a, b)$ acima das barras indicam diferença significativa $(p \leq 0,05)$.

Figura 13. Imunolocalização das proteínas ERBB2 (A, B e C) e ERBB3 (D, E e F) em blastocistos bovinos. As fotomicrografias de confocal representam a marcação do DNA (A e D), a localização dos receptores ERBB2 (B) e ERBB3 (E) e a combinação das duas imagens (C e F). Ambos os receptores estão predominantemente localizados no trofoblasto, o que pode ser confirmado pela ausência de marcação da massa celular interna, na qual não há células do trofoblasblasto, conforme indicado pelas cabeças de seta nas fotomicrografia B e E (40x). .62

Figura 14. Níveis intracelulares de EROs (em unidades arbitrárias de fluorescência) em blastocistos bovinos produzidos em alta tensão de oxigênio na ausência e presença de 
tratamento com antioxidantes (A). As barras do gráfico representam as médias e as barras de erros representam o erro padrão da média. Letras diferentes ( $a, b)$ acima das barras indicam diferença significativa $(p \leq 0,05)$. Fotomicrografias de epifluorescência de blastocistos produzidos em alta tensão de oxigênio na ausência de tratamento (B) e na presença de suplementação com cisteína e cisteamina (C) e corados com CellROX Green (40x).

Figura 15. Expressão relativa das isoformas do miR-199a. Os gráficos A e B apresentam a comparação da expressão relativa das isoformas do miR-199a entre os grupos de blastocistos cultivados em alta tensão de oxigênio na ausência e presença de suplementação do meio de cultivo com antioxidantes (cisteína e cisteamina). As barras representam as médias e as barras de erros representam o erro padrão da média.....

Figura 16. O resultado do Western Blotting, em unidades arbitrárias, demonstrou que a proteína ERBB2 não apresenta diferença de expressão entre os grupos de embriões cultivados em alta tensão na ausência ou presença de antioxidantes ou na baixa tensão de oxigênio. As barras representam as médias e as barras de erros representam o erro padrão da média. Letras diferentes $(a, b)$ acima das barras indicam diferença significativa $(p \leq 0,05)$.

Figura 17. Os níveis de metilação global do DNA (em unidades arbitrárias de fluorescência) em blastocistos bovinos produzidos em alta ou baixa tensão de oxigênio (A). As barras representam as médias e as barras de erros representam o erro padrão da média. Letras diferentes $(a, b)$ acima das barras indicam diferença significativa $(p \leq 0,05)$. Fotomicrografias de confocal de blastocistos produzidos em alta (B) e baixa (C) tensões de oxigênio e imunomarcados para $5-\mathrm{mC}(40 \mathrm{x})$. .66

Figura 18. Mapa das funções biológicas e expressão relativa dos 40 transcritos diferentemente expressos entre os cultivos de alta e baixa tensão de oxigênio para blastocistos bovinos produzidos in vitro. As barras do gráfico representam as médias e as barras de erros representam o erro padrão da média. Letras diferentes $(a, b)$ acima das barras indicam diferença significativa $(p \leq 0,05)$.

Figura 19. Diagrama de Venn indicando o número de miRNAs expressos em cada um dos pools de 10 blastocistos analisados. Representação gráfica da dispersão do valor de Delta Ct entre os pools analisados e o valor do coeficiente de determinação da regressão linear $\left(R^{2}\right)$, indicando alta repetibilidade dos resultados de amplificação de miRNAs entre amostras (repetições) do mesmo grupo. A-P1 = alta tensão - pool 1; A-P2 = alta tensão - pool 2; A-P3 = alta tensão - pool 3; B-P1 = baixa tensão - pool 1; B-P2 = baixa tensão - pool 2; B-P3 = baixa tensão - pool 3. 
Figura 20. Diagrama de Venn indicando a expressão de 352 miRNA em blastocistos bovinos produzidos in vitro. As caixas de texto apresentam as listas dos miRNAs considerados exclusivos para alta e baixa tensões de oxigênio.

Figura 21. Heatmap indicando a expressão dos 8 miRNAs diferentemente expressos $(p \leq 0,05)$ entre os blastocistos desenvolvidos em alta e baixa tensão de oxigênio, para 3 repetições biológicas.

Figura 22. Principais vias enriquecidas pelos miRNAs mais (A) e menos (B) abundantes na alta tensão de oxigênio em relação a baixa tensão de oxigênio. Os valores do eixo $Y$ da esquerda representam o número de genes enriquecidos pelos miRNAs para as respectivas vias, enquanto o eixo $Y$ da direita representa o valor de enriquecimento do score para cada via. O valor de enriquecimento de score é o $-\log _{10}$ do valor de $p$, que é um valor extraído do algoritmo do software DIANA TOOLS com base na proporção de simulações de alvos para os miRNAs.

Figura 23. Expressão relativa dos miRNAs. Os gráficos $A, B, C, D E, F, G$ e $H$ a expressão relativa dos mesmos miRNAs entre os grupos de blastocistos cultivados em alta tensão de oxigênio na ausência e presença de suplementação do meio de cultivo com antioxidantes (cisteína e cisteamina). As barras representam as médias e as barras de erros representam o erro padrão da média. Letras diferentes $(a, b)$ acima das barras indicam diferença significativa $(p \leq 0,05)$

Figura 24. Média das modas e desvio padrão dos tamanhos dos exossomos ( $\mathrm{nm}$ ) observados no meio de cultivo durante os dias 3 e 7 do desenvolvimento de embriões bovinos produzidos in vitro em condições de alta e baixa tensão de oxigênio para 3 repetições biológicas. As barras representam as médias e as barras de erros representam o erro padrão da média. Letras diferentes $(a, b)$ acima das barras indicam diferença significativa $(p \leq 0,05)$.

Figura 25. Média e desvio padrão das concentrações de exossomos (partículas $/ \mathrm{mL}$ ) observada no meio de cultivo durante os dias 3 e 7 do desenvolvimento de embriões bovinos produzidos in vitro em condições de alta e baixa tensão de oxigênio para 3 repetições biológicas. As barras representam as médias e as barras de erros representam o erro padrão da média. Letras diferentes $(a, b)$ acima das barras indicam diferença significativa $(p \leq 0,05)$.

Figura 26. Diagrama de Venn indicando o número de miRNAs expressos em cada um dos pools de meio de cultivo retiradas junto com o feeding no dia 3 do cultivo. As análises foram realizadas para 3 repetições biológicas. Cada repetição biológica consistiu em um pool de meio de cultivo de 3 rotinas. Representação gráfica da dispersão do valor de Delta Ct entre 
os pools analisados e o valor do coeficiente de determinação da regressão linear $\left(R^{2}\right)$, indicando alta repetibilidade dos resultados de amplificação de miRNAs entre amostras (repetições) do mesmo grupo. A-P1 = alta tensão - pool 1; A-P2 = alta tensão - pool 2; A-P3 = alta tensão - pool 3; B-P1 = baixa tensão - pool 1; B-P2 = baixa tensão - pool 2; B-P3 = baixa tensão - pool 3. 75

Figura 27. Diagrama de Venn indicando a presença de 281 miRNA no conteúdo dos exossomos isolados do meio do cultivo de embriões bovinos produzidos in vitro no dia 3 do desenvolvimento. As caixas de texto apresentam as listas dos miRNAs considerados exclusivos para alta e baixa tensões de oxigênio. .75

Figura 28. Heatmap indicando 15 miRNAs diferentemente expressos $(p \leq 0,05)$ no conteúdo de exossomos isolados do meio de cultivo de produção in vitro de embriões desenvolvidos em alta ou baixa tensão de oxigênio no dia 3 do cultivo, para 3 repetições biológicas.

Figura 29. Principais vias enriquecidas pelos miRNAs mais (A) e menos (B) expressos na alta tensão de oxigênio em relação a baixa tensão de oxigênio para exossomos isolados do meio de cultivo no dia 3 em três repetições biológicas. Os valores do eixo $Y$ da esquerda representam o número de genes enriquecidos pelos miRNAs para as respectivas vias, enquanto o eixo $Y$ da direita representa o valor de enriquecimento do score para cada via. $O$ valor de enriquecimento de score é o - $\log _{10}$ do valor de $p$, que é um valor extraído do algoritmo do software DIANA TOOLS com base na proporção de simulações de alvos para os miRNAs.

Figura 30. Diagrama de Venn indicando o número de miRNAs expressos em cada um dos pools de meio de cultivo retiradas no dia 7 do cultivo. As análises foram pools realizadas para três repetições biológicas. Cada repetição biológica consistiu em um pool de meio de cultivo de três rotinas. Representação gráfica da dispersão do valor de Delta Ct entre os pools analisados e o valor do coeficiente de determinação da regressão linear $\left(R^{2}\right)$, indicando alta repetibilidade dos resultados de amplificação de miRNAs entre amostras (repetições) do mesmo grupo. $\mathrm{A}-\mathrm{P} 1$ = alta tensão - pool $1 ; \mathrm{A}-\mathrm{P} 2$ = alta tensão - pool $2 ; \mathrm{A}-\mathrm{P} 3$ = alta tensão pool 3; B-P1 = baixa tensão - pool 1; B-P2 = baixa tensão - pool 2; B-P3 = baixa tensão - pool 3.

Figura 31. Diagrama de Venn indicando a presença de 325 miRNA no conteúdo dos exossomos isolados do meio do cultivo de embriões bovinos produzidos in vitro no dia 7 do desenvolvimento. As caixas de texto apresentam as listas dos miRNAs considerados exclusivos para alta e baixa tensões de oxigênio. 
Figura 32. Heatmap indicando 18 miRNAs diferentemente presentes $(p \leq 0,05)$ no conteúdo de exossomos isolados do meio de cultivo de produção in vitro de embriões desenvolvidos entre alta e baixa tensão de oxigênio no dia 7 do cultivo, para três repetições biológicas. ... 80

Figura 33. Principais vias enriquecidas pelos miRNAs elevados (A) e diminuídos (B) em exossomos isolados do meio de cultivo no dia 7 na alta tensão de oxigênio em relação a baixa tensão de oxigênio para três repetições biológicas. Os valores do eixo $Y$ da esquerda representam o número de genes enriquecidos pelos miRNAs para as respectivas vias, enquanto o eixo $\mathrm{Y}$ da direita representa o valor de enriquecimento do score para cada via. $\mathrm{O}$ valor de enriquecimento de score é o - $\log _{10}$ do valor de $p$, que é um valor extraído do algoritmo do software DIANA TOOLS com base na proporção de simulações de alvos para os miRNAs.

Figura 34. Esquema ilustrativo das reações catalisadas pelas enzimas SOD1, CAT e TXN (em destaque) como resposta ao estresse oxidativo induzido pelo excesso de EROs, durante o metabolismo celular. .90

Figura 35. Esquema ilustrativo da via de sinalização FOXO, no qual foi destacada a função de resposta ao estresse oxidativo. 


\section{LISTA DE TABELAS}

Tabela 1. Médias e desvio padrão (DP) das taxas de clivagem e blastocistos de embriões bovinos produzidos em alta (20\%) e baixa (5\%) tensão de oxigênio. .58

Tabela 2. Médias e desvio padrão (DP) das taxas de clivagem e blastocistos de embriões bovinos produzidos em alta tensão de oxigênio (20\%) na ausência e na presença da suplementação com antioxidantes cisteína e cisteamina $(C+C)$

Tabela suplementar S.1. Sequência dos primers forward específicos para o perfil de 378 miRNAs e 3 endógenos (*) presentes na placa de amplificação.

Tabela suplementar S.2. Ensaios de microfluído dos 93 transcritos e 3 endógenos $\left({ }^{*}\right)$ avaliados para 8 repetições biológicas de embriões cultivados em alta ou baixa tensão de $\mathrm{O}_{2}$

Tabela suplementar S.3. Lista completa da expressão relativa dos 378 miRNAs para 3 repetições biológicas em blastocistos bovinos cultivados em alta e baixa tensões de oxigênio... 115

Tabela suplementar S.4. Expressão relativa dos 93 RNAm avaliados para 8 repetições biológicas para embriões cultivados em alta e baixa tensão de oxigênio. .124

Tabela suplementar S.5. Expressão relativa dos 8 miRNAs avaliados para 4 repetições biológicas de blastocistos bovinos produzidos por fertilização in vitro e cultivados em alta tensão de oxigênio na ausência e presença de suplementação do meio de cultivo com antioxidantes (cisteína e cisteamina). 127

Tabela suplementar S.6. Lista completa da expressão relativa dos miRNAs do conteúdo dos exossomos isolados do meio de cultivo nos dias 3 e 7 do cultivo de embriões produzidos por fertilização in vitro e expostos a diferentes condições atmosféricas, alta e baixa tensão de oxigênio para 3 repetições biológicas...... 


\section{LISTA DE ABREVIATURAS}

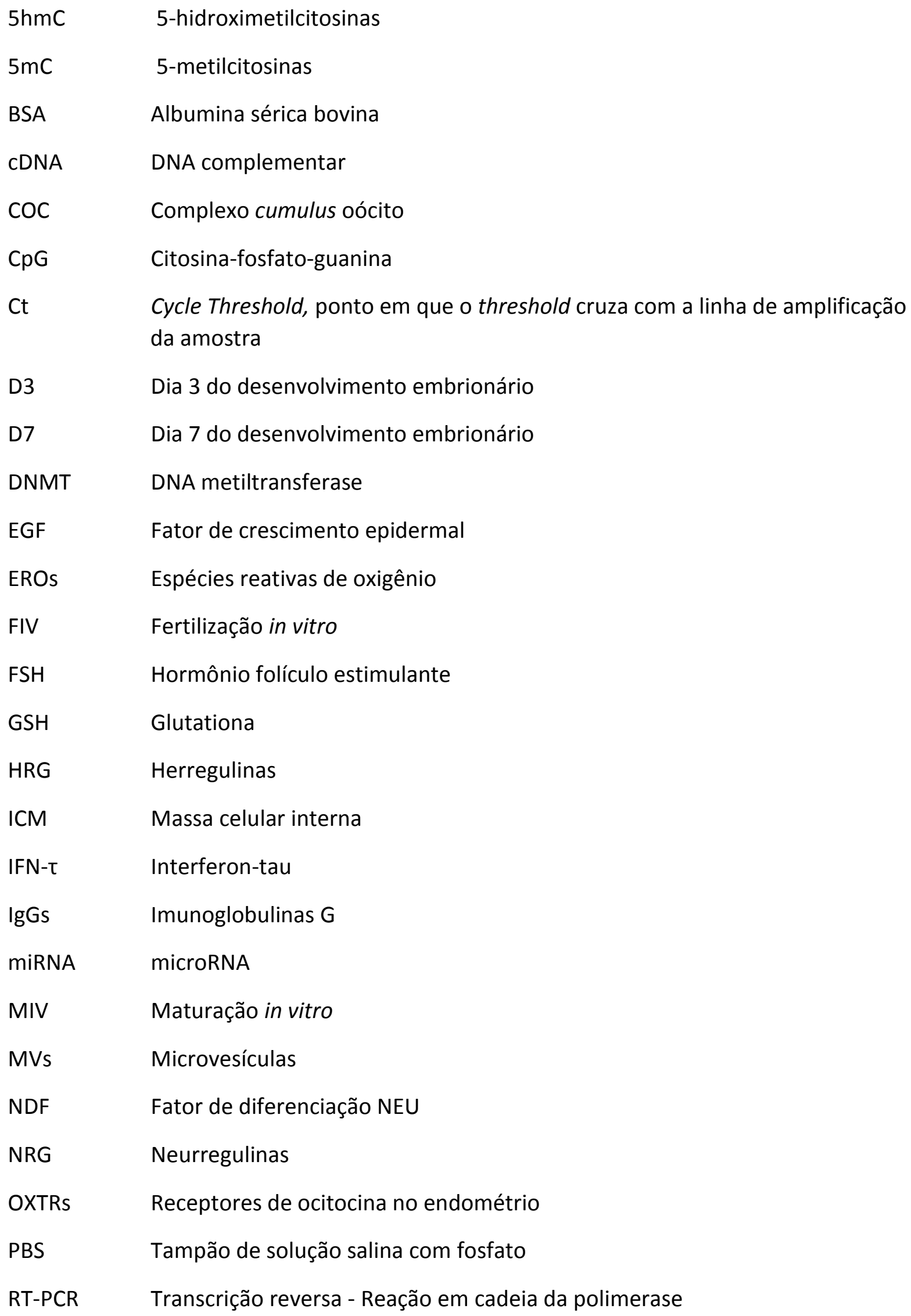




$\begin{array}{ll}\text { PIV } & \text { Produção in vitro } \\ \text { PIVE } & \text { Produção in vitro de embriões } \\ \text { PVDF } & \text { Fluoreto de polivinilideno } \\ \text { RE } & \text { Retículo Endoplasmático } \\ \text { RIPA } & \text { Tampão de ensaio de radioimunoprecipitação } \\ \text { RISC } & \text { Complexo de silenciamento induzido por RNA } \\ \text { RNAm } & \text { RNA mensageiro } \\ \text { SDS } & \text { Dodecil sulfato de sódio } \\ \text { SFB } & \text { Soro fetal Bovino } \\ \text { SOFaa } & \text { Fluido sintético do oviduto com aminoácidos } \\ \text { TCM199 } & \text { Meio de cultura de tecido } \\ \text { TB } & \text { Trofoblasto } \\ \text { TE } & \text { Trofectoderme } \\ \text { TL } & \text { Tyrode-lactato }\end{array}$


SUMÁRIO

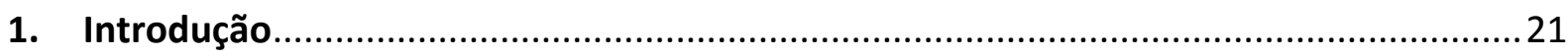

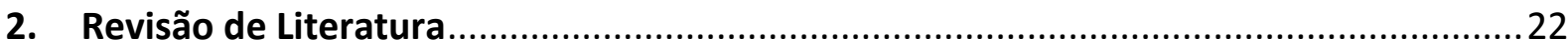

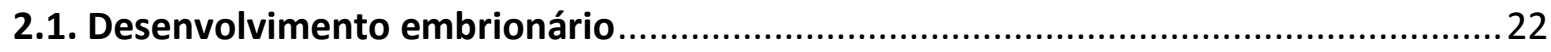

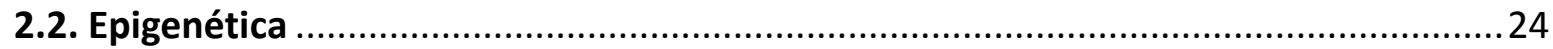

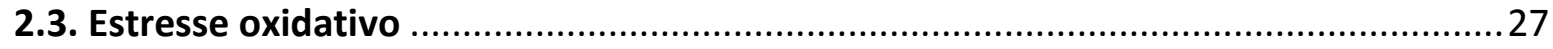

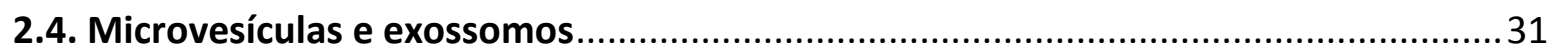

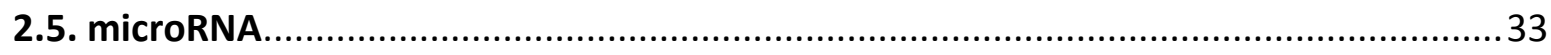

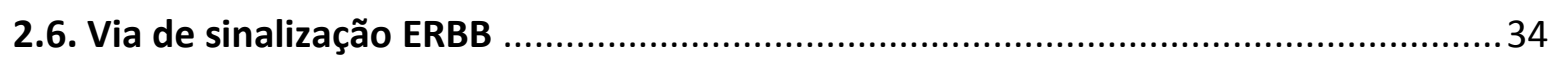

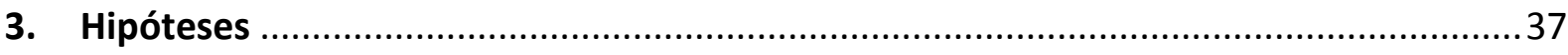

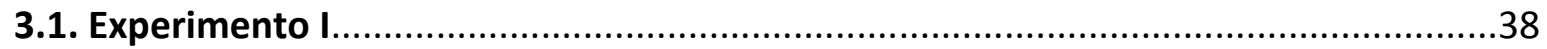

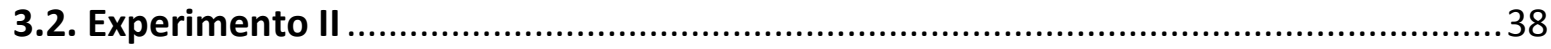

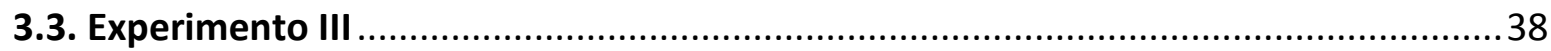

4. Objetivos e Delineamento Experimental................................................................. 39

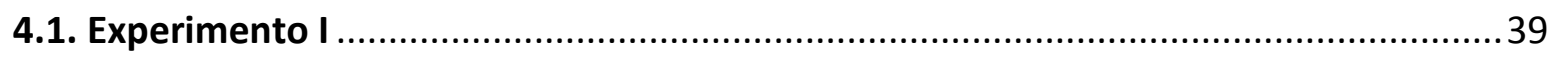

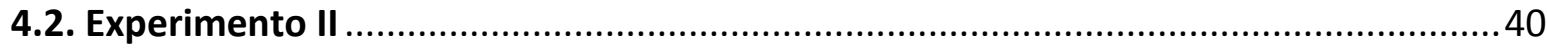

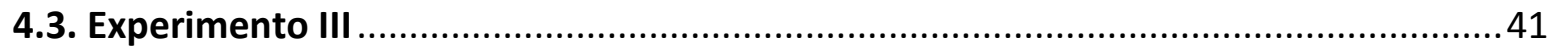

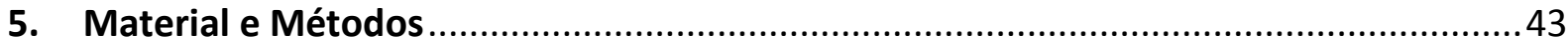

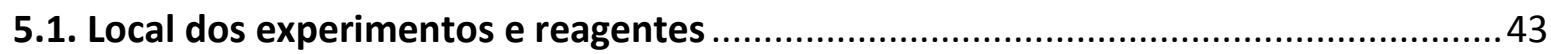

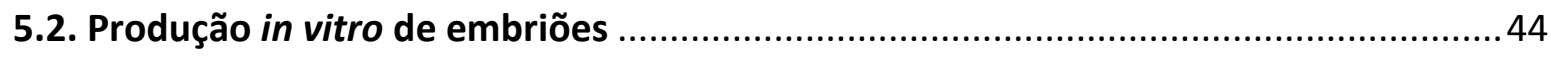

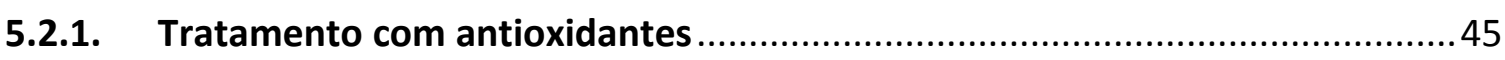

5.2.2. Taxa de clivagem e de blastocistos …............................................................ 45

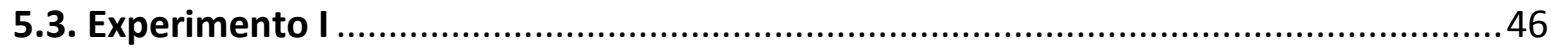

5.3.1. Análise do conteúdo intracelular de EROs para avaliação do estresse

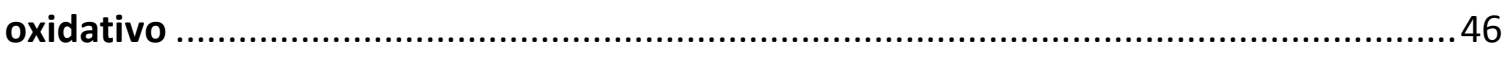

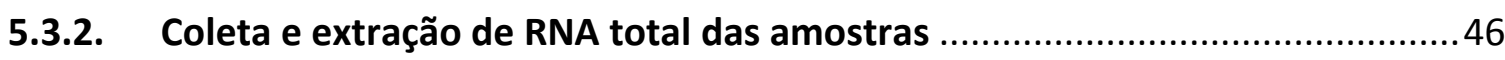

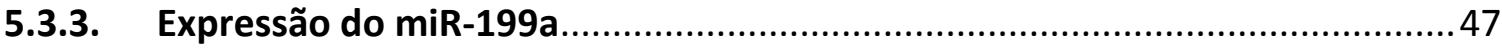

5.3.4. Análise dos RNAm de ERBB2 e ERBB3.................................................... 47

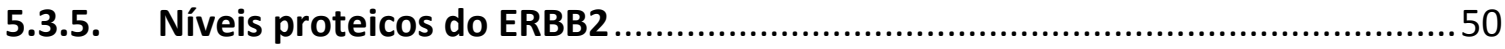

5.3.6. Imunocitoquímica ERBB2 e ERBB3 em blastocistos bovinos ..........................51

5.3.7. Suplementação do meio de cultivo com antioxidantes .................................52

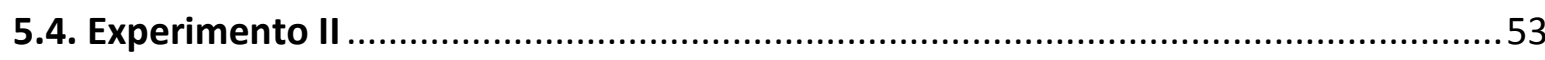




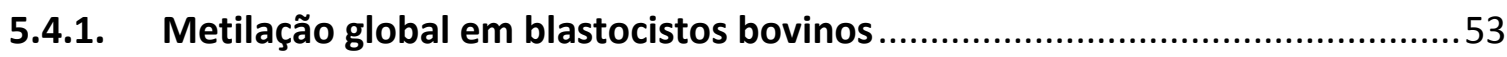

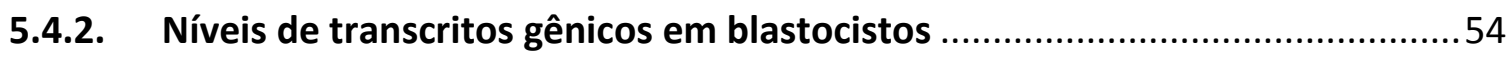

5.4.3. Expressão do perfil de miRNAs para blastocistos bovinos .............................54

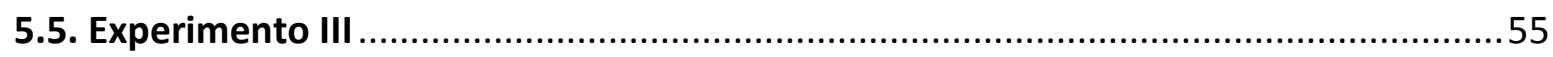

5.5.1. Padrão de secreção dos exossomos presentes no meio de cultivo de embriões

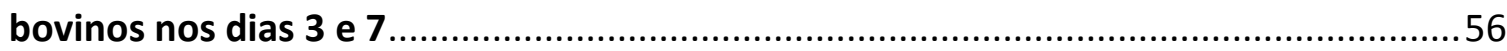

5.5.2. Perfil de microRnAs dos exossomos presentes no meio de cultivo de

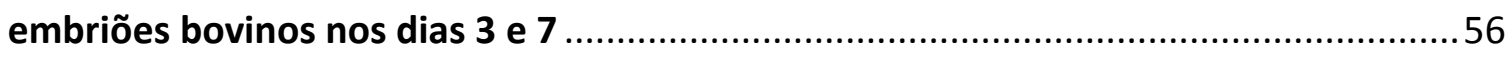

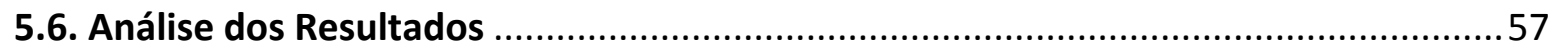

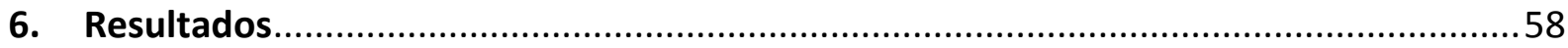

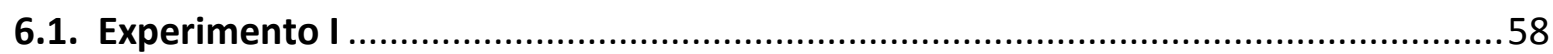

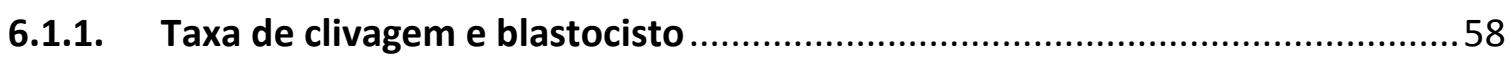

6.1.2. Conteúdo intracelular de EROs para avaliação do estresse oxidativo .............58

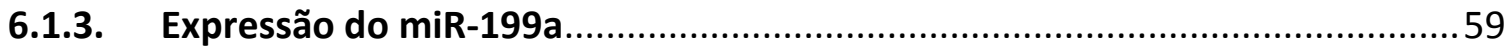

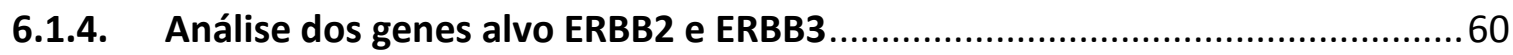

6.1.5. Suplementação do meio de cultivo com antioxidantes ..................................62

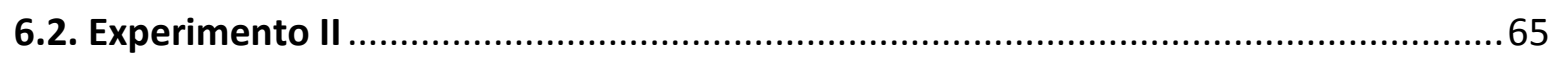

6.2.1. Perfil de metilação global dos blastocistos...................................................65

6.2.2. Níveis de expressão de RNAm nos blastocistos ............................................66

6.2.3. Perfil de microRNAs nos blastocistos............................................................67

6.2.4. Efeito da suplementação do meio de cultivo com antioxidantes na expressão

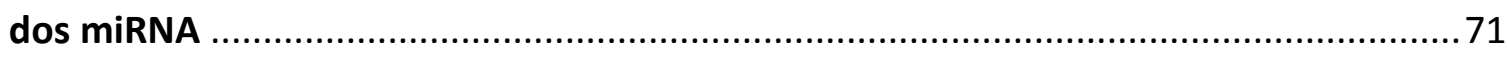

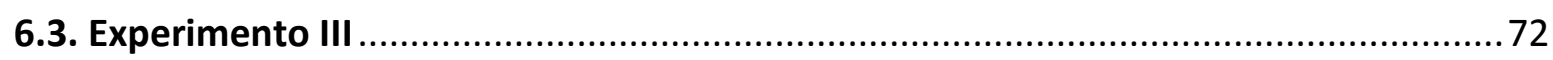

6.3.1. Padrão de secreção dos exossomos presentes no meio de cultivo in vitro de

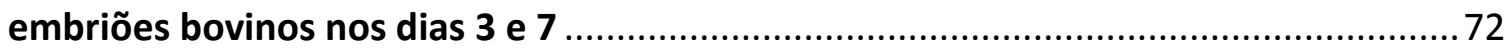

6.3.2. Perfil de microRnAs dos exossomos presentes no meio de cultivo de

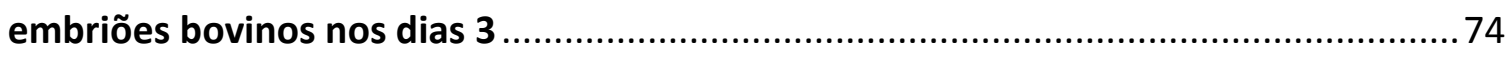

6.3.3. Perfil de microRnAs dos exossomos presentes no meio de cultivo de

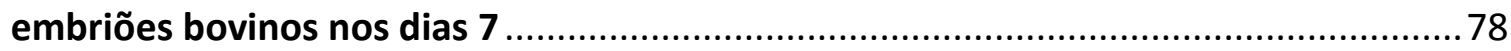

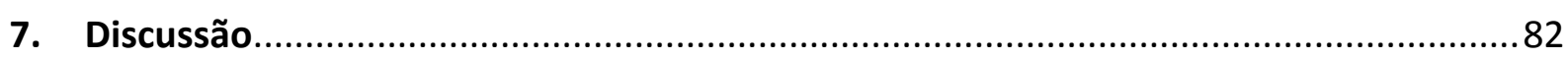

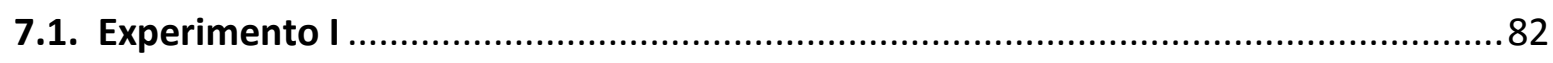

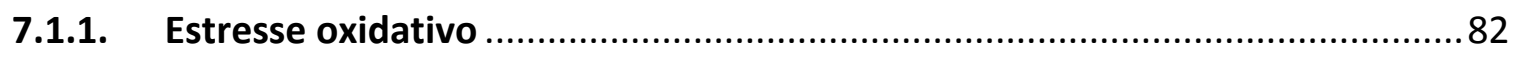

7.1.2. Provável regulação do miR-199a sobre a via ERBB ..................................... 83

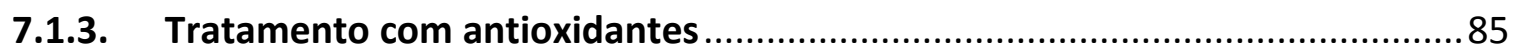

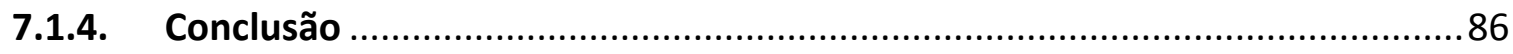




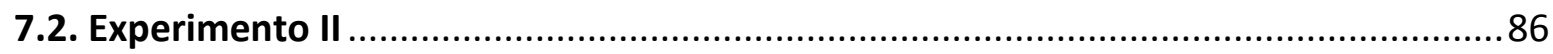

7.2.1. Efeitos do estresse oxidativo no embrião: RNAm relacionados com

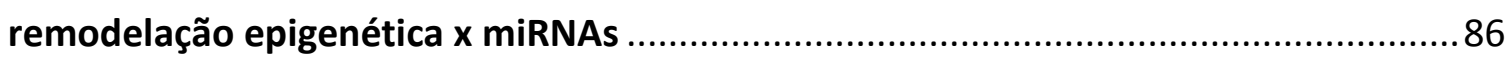

7.2.2. Efeito do estresse oxidativo no embrião: RNAm relacionados com estresse

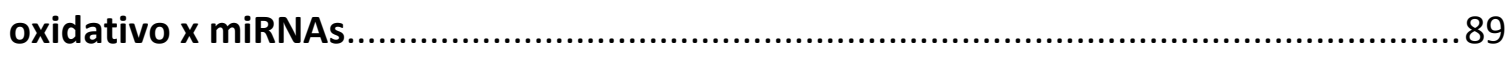

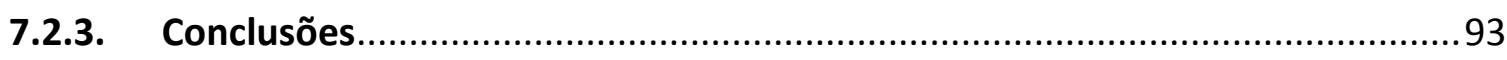

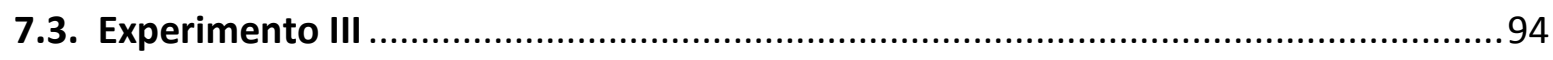

7.3.1. Padrão de secreção dos exossomos presentes no meio de cultivo de embriões

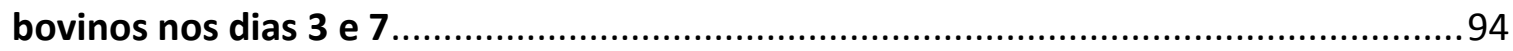

7.3.2. Vias enriquecidas pelos miRNAs presentes no conteúdo dos exossomos do

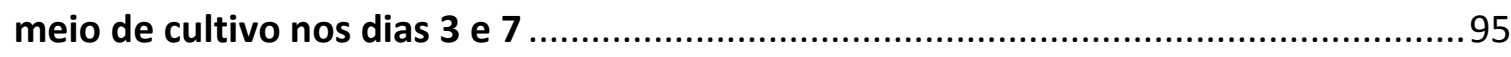

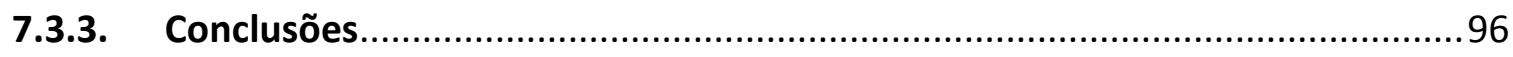

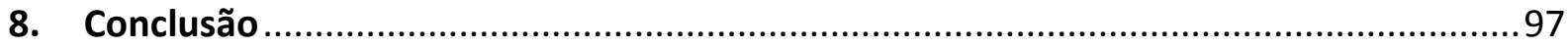

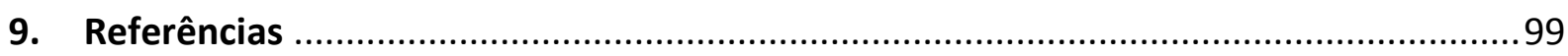

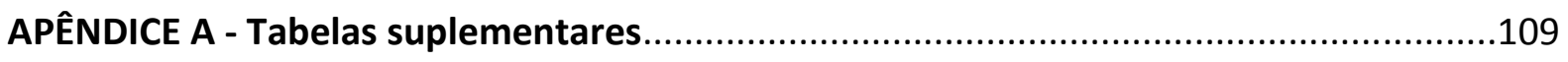

APÊNDICE B - Artigo submetido na Reproductive Sciences............................................138 


\section{Introdução}

Um dos fatores que afetam diretamente a rentabilidade e a eficiência da produção de bovinos é a reprodução. Com o propósito de elevar a eficiência reprodutiva bovina e a velocidade do ganho genético existe uma ampla variedade de biotecnologias reprodutivas que auxiliam na maximização da exploração dos rebanhos, tais como: os protocolos hormonais de manipulação do ciclo estral e a produção in vitro de embriões (PIVE). A PIVE é, atualmente, uma das tecnologias reprodutivas mais empregadas na pecuária nacional, e tem sido intensamente utilizada com o objetivo de aumentar o número de descendentes de animais considerados geneticamente superiores. Contudo, apesar da sua ampla exploração, ainda há necessidade de elucidar os efeitos dos sistemas in vitro sobre o comportamento celular e molecular durante o desenvolvimento embrionário, visando aprimorar os sistemas de produção e o subsequente desenvolvimento do embrião.

Entre os maiores obstáculos na produção de embriões in vitro estão a baixa competência para o desenvolvimento embrionário e danos celulares relacionados com um ambiente de cultivo contendo diversos fatores estressantes, com destaque para o estresse oxidativo. A sobrecarga oxidativa da atmosfera do meio de cultivo dos embriões leva à queda na taxa de formação de blastocistos e ao elevado número de células em apoptose (HE et al., 2012; YOON et al., 2014). Estudos realizados por Yoon et al. (2014) demonstraram experimentalmente que embriões cultivados em atmosfera com tensão de oxigênio próxima a 5\% apresentaram taxas significativamente maiores de formação de blastocistos e sobrevivência celular.

Comumente são utilizados dois modelos de tensão de oxigênio atmosférico para o cultivo in vitro de embriões: a alta tensão $\left(20 \%\right.$ de $\left.\mathrm{O}_{2}\right)$ e a baixa tensão $\left(5 \%\right.$ de $\left.\mathrm{O}_{2}\right)$. Alguns estudos consideram que o modelo de baixa tensão de oxigênio favorece o desenvolvimento embrionário, uma vez que as taxas de blastócitos e prenhez são relativamente mais elevadas (DUMOULIN et al., 1999; PONTES, 2009; AMIN et al., 2014). Além disso, outros estudos demonstram que a alta tensão de oxigênio durante o cultivo in vitro é um fator estressante que favorece modificações epigenéticas, como a metilação do DNA, promovendo alterações significativas na expressão de reguladores gênicos pós-transcricionais. A partir destas observações, o objetivo da presente pesquisa foi determinar o efeitos da alta tensão de oxigênio sobre os níveis de espécies reativas de oxigênio (EROs) para validação do modelo 
de estresse oxidativo em embriões bovinos. Em seguida avaliar o efeito da alta tensão de oxigênio sobre a o padrão de metilação global e expressão de 378 miRNAs, 96 RNAm e proteína ERBB2 presentes nos embriões para determinar as principais vias e funções afetadas pela condição de estresse. Por fim, definir as alterações geradas pelo estresse oxidativo no padrão de secreção de miRNAs em exossomos presentes no meio de cultivo nos dias 3 e 7 do desenvolvimento embrionário. O objetivo geral deste trabalho é, portanto, investigar os efeitos do estresse oxidativo no embrião e nos exossomos do meio de cultivo da PIVE.

\section{Revisão de Literatura}

\subsection{Desenvolvimento embrionário}

O desenvolvimento embrionário torna-se possível devido a uma prévia aquisição de competência pelo oócito, marcada pelo crescimento do folículo ovariano e maturação do oócito. A maturação oocitária envolve diversos eventos como: modificações estruturais e funcionais no oócito e nas células do cumulus, tais como a formação do estoque de transcritos maternos, condensação do DNA e expulsão do primeiro corpúsculo polar no oócito e multiplicação e expansão das células do cumulus (EPPIG, 2001). O estoque de transcritos maternos fornece suporte para o embrião na fase inicial da embriogênese. Além da produção de RNAs e proteínas pelo próprio oócito, existe um aporte de transcritos oriundos das células do cumulus. Essa entrega de moléculas possibilita a diminuição da transcrição ativa pelo oócito, permitindo a condensação do seu DNA, que é fundamental para o progresso da maturação e extrusão do primeiro corpúsculo polar (LI; ZHENG; DEAN, 2010; SIRARD, 2012).

A atividade celular do embrião durante o desenvolvimento é predominantemente controlada pelos transcritos e proteínas de origem materna, até estes estoques serem gradualmente degradados e substituídos por transcritos de origem do genoma embrionário, período denominado transição materno-zigótica. Este estoque de produtos funcionais do oócito é essencial para reprogramação epigenética do embrião, na qual mecanismos de alteração da estrutura de cromatina alteram o padrão de expressão do genoma e, consequentemente, auxiliam na ativação da transcrição do genoma do embrião. A ativação 
do genoma embrionário é o evento mais importante da transição materno-zigótica e, em bovinos, ocorre entre os estágios de 8 para 16 células, aproximadamente no dia 4 do desenvolvimento embrionário (BARNES; FIRST, 1991; GRAF et al., 2014).

No dia 6 do desenvolvimento o embrião bovino inicia a produção de interferon-tau

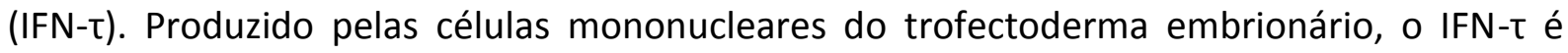
responsável por sinalizar o reconhecimento materno e bloquear os receptores de estradiol, consequentemente inibindo, também, os receptores de ocitocina no endométrio (OXTRs) e a

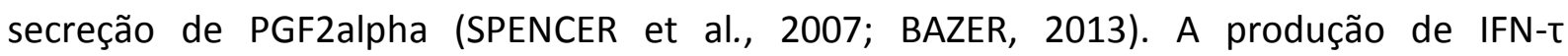
permanece até, aproximadamente, o dia 24 do desenvolvimento. O IFN- $\tau$ sinaliza, nos ruminantes, o início do período de implantação embrionária, estimulando a receptividade uterina e o crescimento placentário (MCGEADY et al., 2006).

A fase de implantação embrionária ocorre após o alongamento embrionário completo, quando o embrião compreende inteiramente os dois cornos uterinos, seguida pela aposição, fixação e adesão do trofoblasto embrionário ao epitélio luminal uterino. Contudo, o período para estabelecimento do contato adesivo entre os tecidos materno-embrionário é restrito, entre os dias 17 e 18 do desenvolvimento, e denominado de janela de implantação (BROWN et al., 2004; MCGEADY et al., 2006; SPENCER et al., 2007). A adesão é um processo complexo, envolvendo a formação de heterodímeros por receptores transmembrana, que ao interagir com os receptores maternos, desencadeiam o crescimento, a proliferação e a sobrevivência celular. Em bovinos, a adesão resulta apenas na justaposição das membranas materno-embrionárias, sem desenvolvimento de processos invasivos como observado em primatas e humanos (BAZER et al., 2010).

Em condições in vivo ideiais o desenvolvimento embrionário inicial ocorre durante a migração do embrião pelo oviduto, sob tensão de oxigênio próxima de 5 a 7\% (FISCHER; BAVISTER, 1993; HARVEY, 2007). Na PIVE o ambiente fisiológico do oviduto é substituído pelo ambiente in vitro, com atmosfera (20 ou $5 \%$ de $\left.\mathrm{O}_{2}\right)$, temperatura $\left(\approx 38^{\circ} \mathrm{C}\right)$ e meio de cultivo pré-definidos, que mimetizam as características do oviduto.

O embrião permanece no ambiente in vitro até o dia 7 do desenvolvimento, tempo suficiente para provocar alterações nos transcritos das células embrionárias (AMIN et al., 2014). Estas modificações ocorrem por meio de alterações de expressão de diversas integrinas e metaloproteases, e refletem em um comportamento celular anormal de migração e adesão (CARSON et al., 2000; SPENCER et al., 2007). Contudo, os mecanismos 
associados a estas alterações, relacionadas ao ambiente de cultivo in vitro ainda não foram elucidados

\subsection{Epigenética}

A epigenética é o estudo dos processos que caracterizam o fenótipo e não depende estritamente da sequência de DNA, ou seja, alteram o fenótipo sem alterar o genótipo. Os eventos epigenéticos estão vinculados com alterações de DNA ou de proteínas histonas. As proteínas histonas estruturam-se em agregados de oito unidades, sendo subdivididas em H2A, H2B, H3 e H4 (KORNBERG, 1974). Cada octâmero de histonas acomoda quase duas voltas de DNA (1,7 volta) (BRADDOCK; BALDWIN; BRADBURY, 1981). O agregamento do DNA e o agrupamento dos octâmeros de histonas, permite que o DNA esteja mais ou menos exposto à maquinaria de transcrição, desta forma alterando os perfis de expressão gênica. As modificações epigenéticas são dinâmicas e sensíveis às alterações ambientais (KORNBERG; LORCH, 1999). Além disso, estudos recentes sugerem que as sequências de DNA também participam da determinação da estabilidade do nucleossomo desta forma alterando a sua conformação (HENIKOFF, 2008).

Diferentes modificações epigenéticas são responsáveis por definir quais genes serão transcritos e quais serão silenciados, de modo que a transcrição e tradução de um conjunto especifico de genes definam a função da célula. O núcleo do zigoto mamífero é formado pelos pró-núcleos materno e paterno, que serão sujeitos à reprogramação do padrão epigenético pré-definido nos gametas durante o desenvolvimento embrionário dos progenitores. A onda de reprogramação é responsável por reprogramar genes que não possuem marcas parentais. Os genes imprinted, por exemplo, não participam do processo de reprogramação (MANN; BARTOLOMEI, 2002; OKADA; YAMAGUCHI, 2017). As alterações do processo de reprogramação epigenética durante o desenvolvimento embrionário in vitro ainda não estão completamente compreendidas.

A metilação do DNA é uma alteração epigenética importante para o estabelecimento e manutenção dos padrões de expressão gênica tecido específico e na manutenção da atividade da cromatina. A metilação do DNA é caracterizada pela adição de um radical metil na posição 5 do anel pirimídico que forma a molécula de citosina, transformando-a em uma 5-metilcitosina (BIRD, 2002). Em geral, a metilação tende a ocorrer no contexto de 
dinucleotídeos CpG, em regiões com baixas taxas de mutação e promotoras de genes, denominadas Ilhas CpGs (DEATON; BIRD, 2011). A hipermetilação das ilhas CpGs leva ao aumento da compactação no DNA em torno do octâmero de proteínas histonas, dificultando o acesso da maquinaria de transcrição. Além disso, a metilação pontual do DNA recruta complexos proteicos de ligação, metil-CpG, que auxiliam no agrupamento e compactação dos nucleossomos. O processo de metilação, portanto, está associado à inativação transcricional (HENIKOFF, 2008; MIORANZA, 2014).

Em mamíferos, os padrões e os caminhos para o estabelecimento da metilação do DNA são amplos. Em geral, a manutenção da metilação, após a divisão celular, é realizada pela enzima DNA metiltransferase 1 (DNMT1), que recompõe a metilação das citocinas de acordo com o padrão que permanece nas cópias hemimetiladas, conservando as informações epigenéticas entre as gerações celulares (HIRASAWA et al., 2008). Entretanto, as modificações de metilação são dinâmicas, e novos padrões podem ser estabelecidos pela enzima DNA metiltransferase 3 (DNMT3A e DNMT3B). Estas modificações são fundamentais para a reprogramação do genoma após a fecundação, garantindo o adequado desenvolvimento do embrião (OKANO et al., 1999; UYSAL; AKKOYUNLU; OZTURK, 2015). Todas as isoformas das DNMTs podem ser detectadas no desenvolvimento inicial do embrião, contudo a DNMT3A é a isoforma predominantemente expressa (WATANABE et al., 2002). A reprogramação é marcada por eventos epigenéticos, envolvendo uma onda de desmetilação dos genomas de origem materna e paterna, seguida por uma onda de metilação "de novo" do genoma do embrião, que ocorrem durante o desenvolvimento embrionário inicial (MAYER et al., 2000; MANN; BARTOLOMEI, 2002). Esse processo permite a modificação dos padrões de metilação herdados dos pais (exceto para os genes imprinted) e determina o padrão de metilação próprio do embrião, contribuindo para a ativação do genoma embrionário (REIK; DEAN; WALTER , 2001; MIORANZA, 2014) (Figura 1).

A desmetilação dos genomas de origem materna e paterna não ocorre de maneira simétrica. O genoma materno sofre uma desmetilação passiva, na qual o padrão de metilação é gradativamente perdido de acordo com o aumento das clivagens embrionária (SANTOS et al., 2002). A desmetilação passiva ocorre devido aos baixos níveis de DNMT1 durante as mitoses, até o estágio de 4 células do embrião (REIK; DEAN; WALTER, 2001). 0 genoma paterno, por sua vez, passa por uma desmetilação ativa, que é mais rápida em relação à passiva. A família de enzimas TET (TET1, TET2 e TET3) promovem a desmetilção 
ativa no zigoto, através da oxidação das 5-metilcitosinas $(5 \mathrm{mC})$ em 5 -hidroximetilcitosinas $(5 \mathrm{hmC})$ seguida por um mecanismo de reparo e excisão de bases do DNA (GEHRING; REIK; HENIKOFF, 2009; IQBAL et al., 2011). A substituição contínua de $5 \mathrm{mC}$ por $5 \mathrm{hmC}$ e a excisão do radical metil da citosina geram um processo ativo de desmetilação do genoma paterno. Contudo, as enzimas TETs não atingem o genoma materno, cujas metilações estão protegidas pelo fator maternal Stella. Entre as enzimas TET, a TET3 é especificamente expressa no zigoto, enquanto as TET1 e TET2 são, respectivamente, ausentes e pouco expressas no zigoto. A TET3 é, portanto, a principal responsável pela desmetilação do prónúcleo paterno (GU et al., 2011; WOSSIDLO et al., 2011).

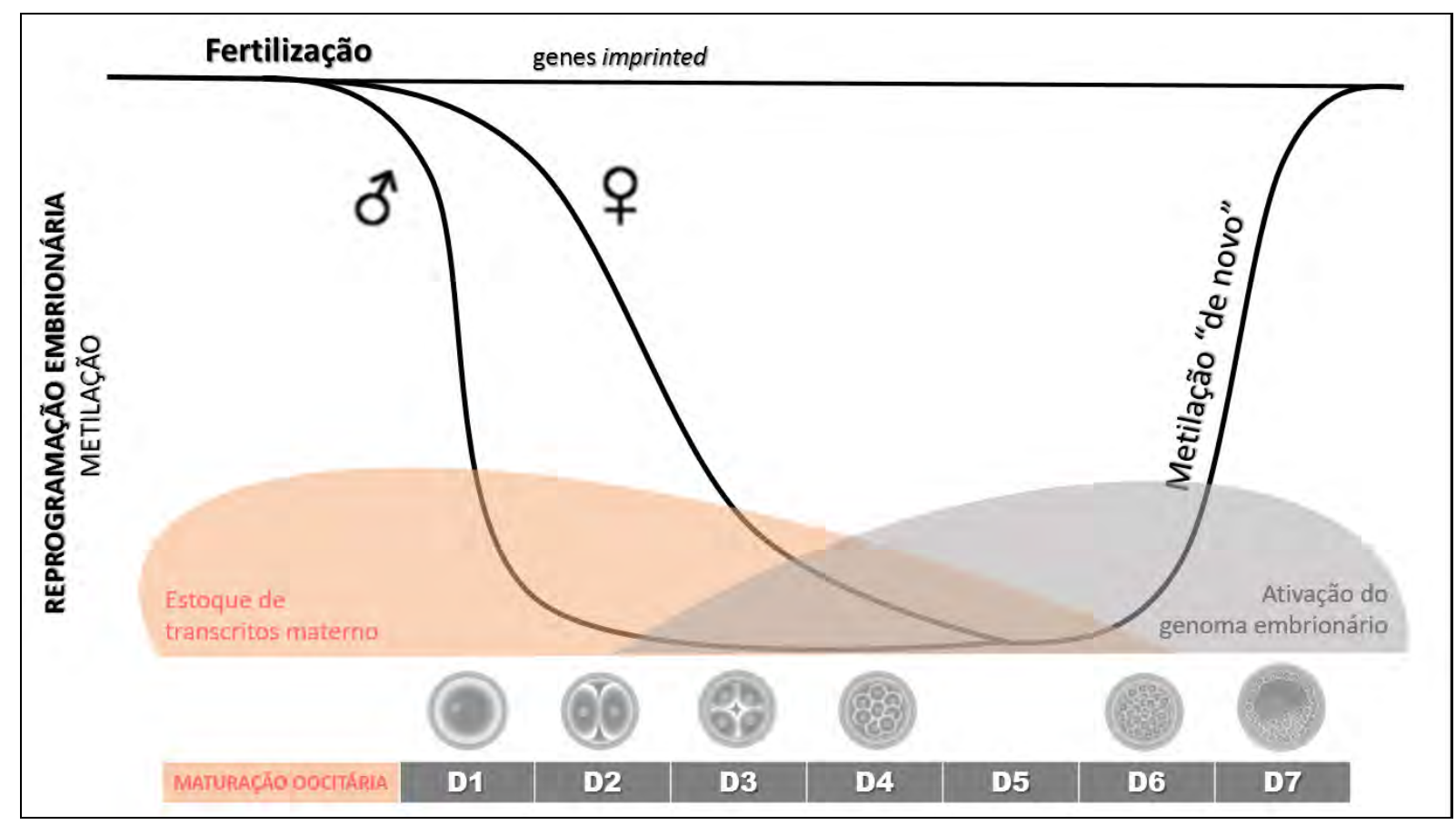

Figura 1. Esquema ilustrativo da reprogramação embrionária que ocorre durante o desenvolvimento embrionário inicial. A reprogramação embrionária envolve, principalmente, dois eventos: reprogramação epigenética, através das ondas de desmetilação e metilação "de novo"; e a transição materno-embrionária, com a depleção gradual dos transcritos e proteínas maternos, concomitante com a crescente produção de transcritos do embrião (ativação do genoma embrionário). A ativação completa do genoma do embrião, em bovinos, ocorre entre os estágios de 8 e 16 células, próximo ao dia 4 do desenvolvimento embrionário.

Durante o estado desmetilado, as células embrionárias estabelecem um estado de pluripotência. $\mathrm{O}$ estresse oxidativo no ambiente de cultivo in vitro favorece o recrutamento das enzimas DNA metiltransferase 1 (DNMT1), aumentando o potencial de manutenção dos 
padrões hipermetilados e dificultando a onda de desmetilação durante o desenvolvimento embrionário. Entretanto, os efeitos epigenéticos da elevada presença de EROs durante o desenvolvimento embrionário são pouco explorados na espécie bovina (IORIO et al., 2007; HE et al., 2012; MIORANZA, 2014). Portanto, parte deste estudo tem como objetivo determinar os efeitos do estresse oxidativo sobre o padrão de metilação global do DNA dos blastocistos e na expressão de transcritos ligados a funções de regulação epigenética.

\subsection{Estresse oxidativo}

Apesar do significante avanço das técnicas de produção de embriões in vitro, sabe-se que o desenvolvimento embrionário de mamíferos é afetado negativamente pela composição do meio, pH e tensão de oxigênio, que compõem o ambiente artificial (MENEZO et al., 2016). Estas condições afetam o metabolismo das células embrionárias, levando a efeitos nos processos de síntese de DNA e proteínas, transporte de aminoácidos e estresse oxidativo (AMIN et al., 2014).

O estresse oxidativo é definido como um distúrbio no estado de equilíbrio no sistema pró-oxidante e antioxidante das células, representados pela produção e eliminação de espécies reativas de oxigênio (EROs). As EROs, conhecidas também como radicais livres, são produtos do metabolismo aeróbico celular, na qual uma molécula de $\mathrm{O}_{2}$ é reduzida em duas moléculas de água, através da incorporação de 4 elétrons. Contudo, quando essa redução ocorre de forma incompleta, ou seja, agregando menos de 4 elétrons, há a formação das EROs: superperóxidos $\left(\mathrm{O}_{2}{ }^{-}\right)$, peróxidos de hidrogênio $\left(\mathrm{H}_{2} \mathrm{O}_{2}\right)$ e radicais de hidroxila $\left(\mathrm{OH}^{-}\right)$ (MENEZO et al., 2016). Estes metabólitos, parcialmente reduzidos, são instáveis e altamente reativos, características que condicionam um comportamento de interação com moléculas de lipídios, carboidratos e ácidos nucleicos, visando adquirir elétrons e reestabelecer a estabilidade das moléculas. Como consequência, as moléculas que concedem os elétrons sofrem oxidação, gerando danos celulares, como peroxidação lipídica, alterações na membrana e no DNA mitocondrial, danos no retículo endoplasmático, desnaturação proteica e alterações no fuso meiótico, que favorecem a produção de mais EROs (CROCOMO et al., 2012; AMIN et al., 2014). Apesar do excesso de EROs ser nocivo às células, estas moléculas são necessárias como sinalizadoras em reações do ciclo celular. Portanto, a redução 
excessiva de EROs pode levar à parada do desenvolvimento embrionário devido ao comprometimento de funções biológicas (HARVEY, 2007; ROCHA-FRIGONI, 2016).

Os níveis de EROs produzidos durante os estágios do desenvolvimento embrionário são inconstantes. Nasr-Esfahani e Johnson Nar e colaboradores (1991) relataram um aumento na produção de EROs (excesso de $\mathrm{H}_{2} \mathrm{O}_{2}$ ) logo após a ativação dos oócitos de camundongo, e o relacionaram com o bloqueio do desenvolvimento no estágio de 2 células. Posteriormente, Morales et al. (1999) demonstraram que os zigotos bovinos são mais sensíveis aos efeitos deletérios de fragmentação de DNA e indução da lise celular causado pelo excesso de $\mathrm{H}_{2} \mathrm{O}_{2}$ em comparação com embriões com maior número de blastômeros (916 células). Os estágios iniciais de zigoto e duas células podem ser considerados, portanto, pontos críticos no desenvolvimento do embrião, sendo mais suscetíveis à perda embrionária ligada ao estresse oxidativo.

$\mathrm{O}$ principal mecanismo relacionado com a produção de EROs, principalmente $\mathrm{H}_{2} \mathrm{O}_{2} \mathrm{e}$ $\mathrm{O}_{2}^{-}$no embrião, é o de oxidase da xantina, no qual a purina, oriunda do processamento de glicose pela via pentose fosfato, é transformada em hipoxantina, tóxica para embrião, que é degradada em xantina e EROs (NASR-ESFAHANI; JOHNSON, 1991). Após a ativação do genoma embrionário há a ativação da transferase hipoxantina fosforibosil (HPRT), responsável pelo resgate da purina, o que auxilia na limitação da produção das EROs (DOWNS; DOW, 1991; GUERIN; EL MOUATASSIM; MENEZO, 2001). Além disso, o equilíbrio oxidativo pode ser influenciado pelas condições ambientais, como aumento da concentração de glicose ou oxigênio, que elevam a atividade metabólica e resultam em aumento das EROs (GUERIN; EL MOUATASSIM; MENEZO, 2001).

Os antioxidantes endógenos atuam neutralizando as EROs, a fim de manter uma atividade equilibrada destes metabólitos. Estudos realizados por Amin et al. (2014) demonstraram que os genes ligados à função antioxidante não possuem expressão significativa até o estágio de 4 células do desenvolvimento embrionário, tanto no desenvolvimento em alta quanto em baixa tensão de $\mathrm{O}_{2}$, de maneira que a resposta do embrião ao estresse oxidativo ocorre de modo significativo apenas após a ativação do genoma embrionário. Durante o desenvolvimento anterior à ativação do genoma embrionário, parte dos antioxidantes que combatem o estresse oxidativo pertencem ao estoque materno de transcritos e proteínas produzidos durante a oogênese (CROCOMO et al., 2012; AMIN et al., 2014). 
A glutationa (GSH) é um tripeptídeo tiol que compõe o estoque materno de antioxidantes não enzimáticos do embrião. O GSH remove o excesso de EROs através da redução dos peróxidos e hidroperóxidos em produtos inativos, e detoxificação de proteínas tioladas. Além de combater o estresse oxidativo, o GSH possui funções nos processos de síntese de DNA e proteína, transporte de aminoácidos e descondensação do pronúcleo paterno após a fertilização (DE MATOS et al., 1996; GASPARRINI et al., 2006; AMIN et al., 2014). Portanto, o GSH produzido durante a maturação fornece um forte indício da competência do oócito para viabilizar o posterior desenvolvimento embrionário (ROCHAFRIGONI et al., 2014).

A síntese de GSH ocorre por meio do ciclo $\gamma$-glutamil-cisteína que é dependente da quantidade de cisteína disponível. A cisteína é um composto de tiol de baixo peso molecular que, no citoplasma do oócito, atua como precursor para a síntese de GSH. Como o estímulo da síntese de GSH auxilia na manutenção do estado de redução-oxidação, estas moléculas são usadas rotineiramente como suplemento do meio de maturação de oócitos e de cultivo embrionário. A molécula da cisteína, entretanto, é instável em ambiente extracelular, sofrendo rápida oxidação em cistina e, consequentemente, atuando apenas nas primeiras horas da maturação. Todavia, quando associada a outra molécula de tiol, como a cisteamina, a cistina é reduzida novamente em cisteína, retomando a produção de GSH (DE MATOS et al., 1995). Além disso, a cisteamina também atua como agente redutor do radical hidroxila $\left(\mathrm{OH}^{-}\right)$e como quelante de alguns íons metálicos, auxiliando na redução dos danos do estresse oxidativo (GUERIN; EL MOUATASSIM; MENEZO, 2001; GASPARRINI et al., 2003). As células do cumulus bovinas também são capazes de converter a cistina em cisteína pelo mecanismo de permuta aniônica e a cisteína convertida é entregue ao oócito para a produção de GSH através das junções comunicantes (DE MATOS; FURNUS; MOSES, 1997) (Figura 2). 


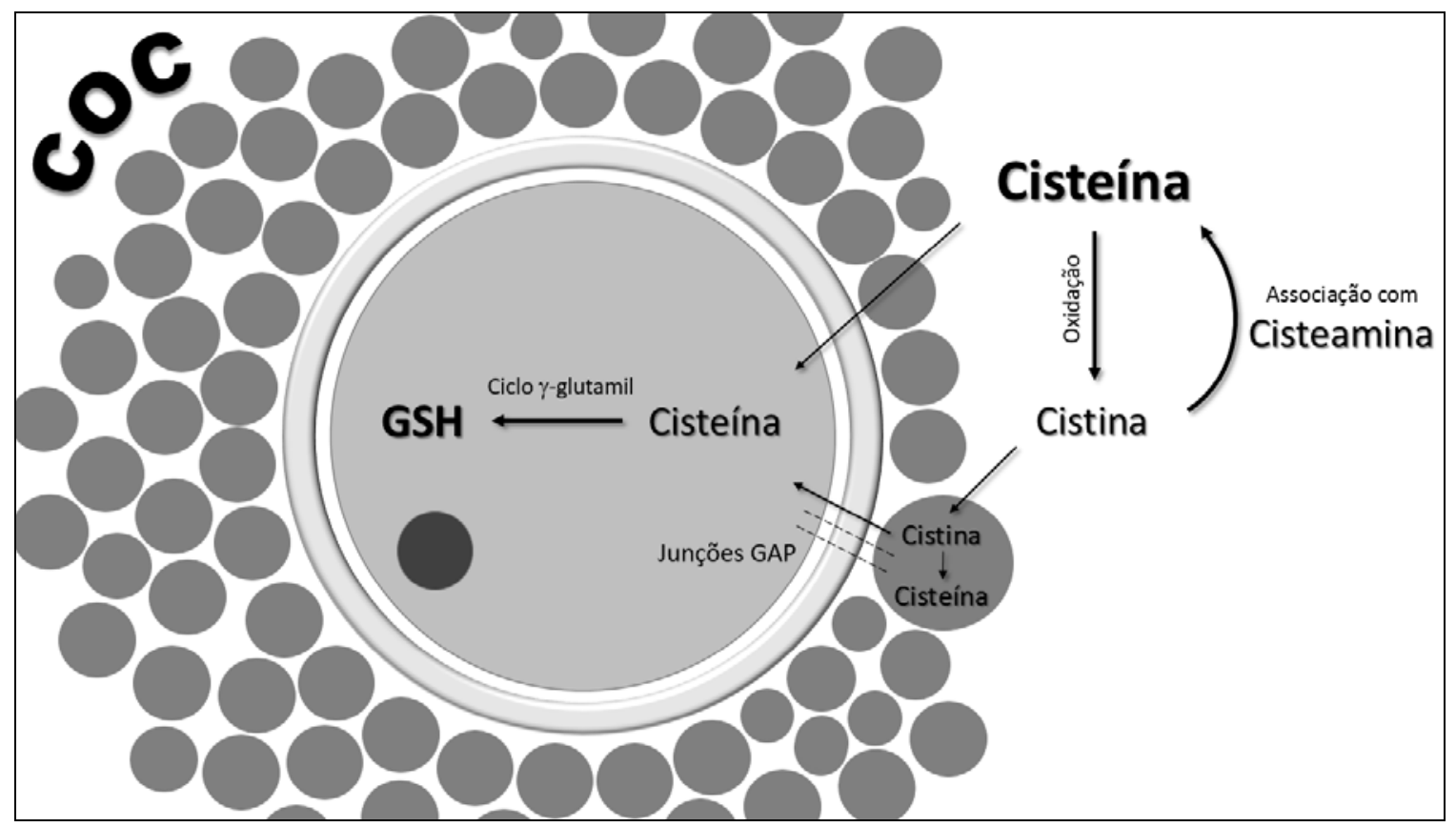

Figura 2. Esquema ilustrativo do metabolismo de cisteína no complexo cumulus oócito, durante a suplementação do meio de maturação do oócito com cisteína e cisteamina. $\mathrm{COC}=$ Complexo cumulus oócito; GSH = Glutationa.

A produção de EROs é aumentada em condições de cultivo in vitro devido a fatores ambientais como a alta tensão de oxigênio $\left(\mathrm{O}_{2}\right)$, cátions metálicos na água ou em reagentes utilizados, exposição à luz, presença de espermatozoides e danos celulares prévios de manipulação (CROCOMO et al., 2012). Além disso, a ausência do sistema de defesa antioxidante do útero leva à potencialização dos danos causados pelas EROs, consequentemente reduzindo a viabilidade embrionária e aumentado as perdas decorrentes do estresse oxidativo (GASPARRINI et al., 2006) . Na condição de alta tensão de oxigênio há um agravamento do estresse oxidativo devido a uma elevada concentração de EROs gerada pelo metabolismo celular e pela deficiência dos mecanismos antioxidantes. Nesse contexto, a suplementação do meio de maturação in vitro com cisteamina e cisteína fornece subsídios para a síntese de uma quantidade adequada de GSH, o que auxilia na redução das lesões celulares pelos EROs e contribuem para um desenvolvimento embrionário saudável (GASPARRINI et al., 2003; ROCHA-FRIGONI, 2016). Parte do objetivo deste estudo é determinar se a alta tensão de oxigênio é capaz de gerar alteração nos níveis de EROs e se essas alterações, assim como as alterações na expressão de miRNAs e RNAm, podem ser revertidas com a suplementação com antioxidantes dos meios de cultivo da maturação e de parte do desenvolvimento embrionário. 


\subsection{Microvesículas e exossomos}

O diálogo bidirecional materno-embrionário sincronizado determina o sucesso dos eventos reprodutivos e progressão da gestação (SPENCER et al., 2007). Entre os mecanismos que promovem essa comunicação, as microvesículas e os exossomos têm sido propostos como importantes mediadores de informações entre o embrião e o oviduto e entre o embrião e o útero, em condições fisiológicas, e entre embriões durante a produção in vitro (NG et al., 2013; SAADELDIN et al., 2014).

Microvesículas (MVs) e exossomos são nanopartículas compostas por uma bicamada fosfolipídica, com capacidade de transporte de moléculas bioativas entre as células próximas ou distantes através do ambiente extracelular (RAPOSO; STOORVOGEL, 2013). As principais diferenças entre as MVs e os exossomos são com relação ao tamanho, sendo as MVs (100 - $1000 \mathrm{~nm})$ maiores que os exossomos (40 - $100 \mathrm{~nm})$, e mecanismo de produção (THÉRY; OSTROWSKI; SEGURA, 2009). Em geral, os exossomos se formam no interior do lúmen das vesículas dando origem a corpos multivesiculares (MVBs), enquanto as MVs são produzidas a partir da própria membrana plasmática da célula (BARKALINA et al., 2015).

Os exossomos podem conter em seu interior RNAs mensageiros, proteínas, microRNAs, fatores de crescimento e citocinas, que são encaminhados às células-alvo específicas, correspondentes aos receptores célula-específicos na superfície dos exossomos (VALADI et al., 2007; MITTELBRUNN et al., 2011). As proteínas e os microRNAs associados aos exossomos estão prevalentemente relacionadas com funções durante a fertilização, desenvolvimento embrionário inicial e implantação (WYDOOGHE et al., 2015). Enquanto, o conteúdo das MVs é composto por proteínas, RNAm e microRNAs, que têm sido associados a funções de manutenção e proliferação celular, apoptose, reparação tecidual, angiogênese e resposta imune (AL-DOSSARY; MARTIN-DELEON, 2015; MACHTINGER; LAURENT; BACCARELLI, 2015).

Estudos de Al-Dossary, Strehler e Martin-Deleon (2013) descreveram, pela primeira vez, a secreção de exossomos pelo oviduto de camundongos. Posteriormente, Almiñana (2015) caracterizou os exossomos liberados pelo oviduto bovino, indicando a presença da glicoproteína oviduto-específica (OVGP) e proteína A8 heat shock (HSPA8), fundamentais na promoção de um ambiente adequado para o suporte da fertilização e do desenvolvimento embrionário inicial. Além disso, Almiñana (2015) sugere que o embrião é capaz de atuar 
como mediador do seu próprio ambiente através dos exossomos. Contudo, a abrangência dessa comunicação ainda é pouco compreendida.

A presença de vesículas no endométrio foi descrita primeiro em camundongos por Griffiths et al. (2008), que determinou a presença de proteínas SPAM1 (molécula de adesão ao espermatozoide 1) em seu conteúdo. As proteínas SPAM1 são adquiridas pelo espermatozoide no trato reprodutivo da fêmea durante a capacitação in vivo, colaborando para a fertilização. O estudo recente de Greening et al. (2016) relacionou o conteúdo proteico das vesículas do ambiente uterino com mudanças fundamentais para a implantação: migração celular, remodelamento da matriz extracelular e aprimoramento da capacidade adesiva do trofoblasto (principalmente através da via de sinalização adesão focal quinase - FAK).

Os exossomos têm sido relacionados com alterações no epitélio endometrial humano mediadas por mecanismos de regulação pós-transcricionais, microRNAs, que atuam, através da comunicação materno-embrionária, favorecendo o potencial de implantação uterino (APLIN, 2006; NG et al., 2013). No estudo de Ng et al. (2013), por exemplo, os autores correlacionaram os miRNAs dos exossomos isolados do fluido uterino com as funções biológicas de interação entre fibronectinas e integrinas, que regulam as junções adesivas nos sítios de implantação, e ativação de múltiplas citocinas conhecidas por atuarem na implantação.

A comunicação mediada por microvesículas e exossomos entre as células no microambiente da produção in vitro foi relatada primeiramente por SAADELDIN et al. (2014), em embriões partenogenéticos de suínos com co-cultivo e desenvolvidos em baixa tensão de oxigênio. A análise do conteúdo dos exossomos revelou a presença de transcritos relacionados com pluripotência, como OCT4 (Transportador de carnitina orgânico 4), SOX2 (SRY região determinante do sexo Y caixa 2), C-MYC (Mielocitomatose homólogo do oncogene viral v-myc) e NANOG, que beneficiam a capacidade de desenvolvimento do embrião (SAADELDIN et al., 2014; WYDOOGHE et al., 2015). Estes dados permitem sugerir que as células no microambiente de cultivo in vitro de embriões utilizam as vesículas como mecanismo para promover a qualidade do seu próprio ambiente, favorecendo seu desenvolvimento.

A secreção dos exossomos pode ser influenciada pelos hormônios estradiol e progesterona (GREENING et al., 2016) ou pelo estresse oxidativo (KING; MICHAEL; GLEADLE, 
2012; SALOMON et al., 2013). Contudo, não existe relatos de como o estresse oxidativo do ambiente de cultivo de embriões produzidos in vitro pode mediar o padrão de secreção dos exossomos. Portanto, parte deste estudo tem o objetivo de compreender como o estresse oxidativo altera os exossomos secretados no meio de cultivo durante a produção in vitro.

\section{5. microRNA}

O desenvolvimento embrionário está relacionado com diversos mecanismos de proliferação e diferenciação celular, que por sua vez são regulados por mecanismos epigenéticos, fatores de transcrição e por pequenos RNAs não codificadores (miRNAs). Os miRNAs vêm demonstrando grande importância na regulação de processos biológicos, sendo que, aproximadamente, $50 \%$ de todos os genes codificadores de proteínas conhecidos nos mamíferos sofrem regulação através de miRNAs (MCBRIDE et al., 2012).

Os miRNAs constituem uma das famílias dos pequenos RNAs, com comprimento aproximado entre 18 a 25 nucleotídeos. Comumente são relacionados à regulação gênica pós-transcricional, atuando por meio da degradação ou pela repressão da tradução dos RNAm em mamíferos (BARTEL, 2004). Em geral, a biogênese dos miRNAs é iniciada pela transcrição de genes independentes, regiões intergênicas ou de íntrons em pri-miRNA, principalmente, via RNA polimerase II. Ainda dentro do núcleo eles são processados pela endonuclease RNAase III (Drosha) em miRNAs precursores (pré-miRNA), assumindo a forma stem-loop. Após o processamento são transportados para o citoplasma, via mecanismo dependente de Exportina-5, onde uma segunda endonuclease RNAase III (Dicer) cliva o prémiRNA em miRNA maduro dupla fita (miRNA:miRNA), desta forma mais de um pré-miRNA pode dar origem a um mesmo miRNA maduro. Em geral, uma das fitas é transformada em miRNA maduro e a outra degradada, contudo, existem casos nos quais as duas fitas são transformadas em miRNA maduro (BARTEL, 2004, 2009; HA; KIM, 2014).

Os miRNAs maduros, por sua vez, são transportados pelo citoplasma por proteínas argonautas (complexo RISC), até regiões alvo específicas do mRNA, a fim de realizar as atividades de regulação (AMERES; MARTINEZ; SCHROEDER, 2007). A regulação póstranscricional ocorre após a interação, por complementariedade, do miRNA com a região 3' UTR do mRNA-alvo. Quando ocorre um pareamento perfeito das regiões ocorre a degradação do mRNA, entretanto, quando o pareamento é imperfeito ocorre a repressão da 
tradução do mRNA, o que reduz os níveis proteicos dos genes-alvo (GUO et al., 2010; IWAKAWA; TOMARI, 2013). O pareamento imperfeito aumenta a possibilidade de regulação do miRNA, ou seja, um miRNA pode exercer atividade regulatória em mais de um miRNAalvo, constituindo uma importante rede de regulação celular (RICARTE-FILHO; KIMURA, 2006)

Os miRNAs podem sofrer regulação através de processos epigenéticos ligados principalmente à metilação de ilhas CpG controladoras dos miRNAs. Durante o estresse oxidativo as EROs promovem o recrutamento da enzima DNA metiltransferase 1 (DNMT1), favorecendo a metilação e, consequentemente, dificultando a onda de desmetilação durante o desenvolvimento embrionário (IORIO et al., 2007; HE et al., 2012; MIORANZA, 2014). Estudo realizado por Lee et al. (2012) demonstrou que a inibição da metilação em embriões leva a alterações de expressão de miRNAs, diminuindo a expressão de 48 miRNAs e aumentando a expressão de 17 miRNAs na fase de blastocisto. O miR-199a foi encontrado alterado entre os embriões de PIVE e in vivo apresentando, principalmente, alteração nos padrões de metilação dos precursores (MIORANZA, 2014). No contexto das condições de cultivo in vitro, He e colaboradores (2012) demonstraram que a expressão do miR-199a é alterada pelo estresse oxidativo do ambiente artificial, através da metilação do DNA.

O miR-199a é transcrito das regiões intragênicas dos genes DNM3 (Dynamin 3) e DNM2 (Dynamin 2) (cromossomos 16 e 7), que transcrevem, respectivamente, miR199a-1 e miR199a-2. Estudo de Watanabe et al. (2008) sugeriu que a expressão dos miR199a-1 é dependente da expressão do gene DNM3, de modo que a inibição da transcrição do gene DNM3 leva à não transcrição do miR199a-1. Após as clivagens pelas enzimas Drosha e Dicer, ambas as fitas, que correspondem ao miRNA maturo, são mantidas, sendo denominadas de miR-199a-5p e miR-199a-3p. As duas formas maduras realizam a regulação dos genes alvo ERBB2 e ERBB3 (receptores do fator de crescimento epidérmico -2 e -3), contudo, o miR-199a-5p tem maior afinidade nessa regulação (HE et al., 2012).

\subsection{Via de sinalização ERBB}

Os receptores de tirosina quinase ERBB são glicoproteínas da família de receptores de fatores epidermais de crescimento, constituída por quatro membros: ERBB1, ERBB2, ERBB3 e ERBB4. Estes receptores mediam as atividades de proliferação e diferenciação 
celular em tecidos embrionários e adultos. Diversos estudos têm relacionado a perda de qualquer um dos membros ERBB com morte embrionária durante o desenvolvimento e com anomalias em órgãos neonatais e adultos, tais como cérebro, coração, pele, pulmão e trato gastrointestinal (CHO; LEAHY, 2002; NEGRO; BRAR, 2004; ISHIKAWA et al., 2011); enquanto que a superexpressão dos receptores ERBB tem sido associada ao crescimento desordenado e formação de tumores malignos (ONO; KUWANO, 2006). Os receptores do fator de crescimento epidérmico -2 e -3 (ERBB2 e ERBB3), também denominado de HER-2 e HER-3 em humanos e murinos, têm sido descritos como fatores críticos no crescimento e sobrevivência embrionária, apresentando um importante papel na transdução do sinal em vias que regulam diversas funções celulares como proliferação, diferenciação, migração, apoptose e angiogênese (WATANABE et al., 2008).

Os receptores da família ERBB possuem estrutura proteica semelhante, com três domínios principais: um domínio externo, constituído por duas regiões ricas em cisteína responsáveis pelas interações com ligantes; um domínio transmembrana; e um domínio interno chamado de citoplasmático, constituído por um domínio quinase flamqueado a uma cauda carboxi-terminal (C-terminal), que fosforilam mediante atividade de regulação e catálise dos resíduos de tirosina (ONO; KUWANO, 2006; STEFFENSEN et al., 2008).

Em geral, nos receptores ERBB, a ativação ocorre após a interação do domínio extracelular com ligantes como o fator de crescimento epidermal (EGF), neurregulinas (NRGs) e herregulinas (HRGs), pelo mecanismo de oligomerização. As NRGs são proteínas sinalizadoras de membrana da família EGF, representados por quatro isoformas: NRG-1, NRG-2, NRG-3 e NRG-4, e convencionalmente descritas como ligantes de predileção do heterodímero ERBB2/ERBB3 (BAECKSTROM; ALFORD; TAYLOR-PAPADIMITRIOU, 2000; NAGY et al., 2002). As isoformas das neuregulinas, assim como os ligantes que possuem alta afinidade com os receptores ERBB, possuem um domínio EGF-like que se liga nos dímeros de ERBB da membrana celular e desencadeia a ativação do domínio intracelular através da fosforilação dos resíduos de tirosina quinase, que passam a servir como sítios de ancoragem para proteínas citoplasmáticas distintas envolvidas na cascata de sinalização dos fatores de crescimento epidermal (ONO; KUWANO, 2006).

A especificidade e a potência dos sinais transmitidos pelos receptores ERBB dependem da composição de homo e heterodímeros da membrana celular. Os homodímeros de ERBB3 são incapazes de gerar atividade intrínseca de quinase e, apesar de 
ambos os receptores, heterodímero ERBB2/ERBB3 e homodímero ERBB2, apresentarem atividade de fosforilação dos resíduos de tirosina quinase, o homodímero ERBB2 não possui ligante específico e não gera sinal eficaz para os fatores de crescimento. O domínio citoplasmático do ERBB3 possui maior quantidade de sítios de ancoragem para a subunidades reguladoras do PI3K (Fosfatidilinositol 3-quinase), o que contribui para a resistência de transmissão dos sinais pelo heterodímero ERBB2/ERBB3 (PINKAS-KRAMARSKI et al., 1996; BAECKSTROM; ALFORD; TAYLOR-PAPADIMITRIOU, 2000).

A associação das proteínas em homo ou heterodímeros depende do equilíbrio entre monômeros e dímeros de ERBB2, no qual o heterodímero ERBB2/ERBB3 compete com o homodímero ERBB2, ou seja, um aumento do número de proteínas ERBB3 pode provocar o desarmamento dos homodímeros ERBB2, levando a construção preferencial de heterodímeros ERBB2/ERBB3 (YARDEN, SLIWKOWSKI, 2001). De acordo com Nagy et al. (2002) as áreas da membrana com alta homoassociação da proteína ERBB2 estão positivamente relacionadas com a densidade local de ERBB2 e inversamente relacionadas com a densidade local de ERBB3. O heterodímero ERBB2/ERBB3 tem sido relacionado ao crescimento tanto de tecidos normais como de tumores malignos (STEFFENSEN et al., 2008; WATANABE et al., 2008). A ativação do heterodímero ERBB2/ERBB3 promove o mecanismo inicial básico para a ativação da atividade de diversas vias relacionadas com a atividade mitótica, como a via de sinalização PI3K/AKT (Fosfatidilinositol 3-quinase/ Quinases serina/treonina). A via PI3K/AKT ativada promove a atividade dos fatores de transcrição no núcleo, promovendo a migração, diferenciação e ciclo celular (YARDEN; SLIWKOWSKI, 2001) (Figura 3).

Além de seus efeitos no crescimento, os receptores ERBB2 e ERBB3 têm sido implicados nos processos de interação materno-embrião e implantação embrionária em mamíferos. Durante o desenvolvimento embrionário, em condições fisiológicas, o tecido do endométrio expressa NRGs que desempenham um importante papel na diferenciação, proliferação e sobrevivência celular, aumento na síntese de proteínas e expressão gênica embrionária. Brown et al. (2004) demonstraram a presença de NRG-1, na isoforma NDF (fator de diferenciação NEU), no estroma subepitelial uterino na região em contato com embrião no momento da implantação e NRG-4 em todo epitélio glandular e luminal uterino. O NDF está presente na região endometrial próxima ao blastocisto no momento da fixação durante a janela de implantação, sugerindo uma contribuição deste ligante na interface 
materno-embrionária. A função do NRG-4 no endométrio também é desconhecida, contudo sua expressão coincide com a diferenciação e proliferação do epitélio endometrial durante a janela de implantação, sugerindo uma participação ativa na comunicação bidirecional embrião-útero preparando o endométrio para a implantação embrionária (KLONISCH et al., 2001; BROWN et al., 2004). Os estudos de Brown et al. (2004) sugerem que o ligante NDF possui maior potencial de ligação com o heterodímero ERBB2/ERBB3, sendo uma via de sinalização ativa durante a janela de implantação. Enquanto, o heterodímero ERBB1/ERBB2 pode se ligar ao NRG-4, levando ao aumento da atividade celular.

As taxas de gestação derivadas de embriões produzidos in vitro são inferiores àquelas obtidas com transferência de embriões produzidos in vivo (HASLER, 1998). Além disso, estudos realizados por Pontes (2009) e Bontekoe et al. (2012) demonstraram que embriões produzidos in vitro, com baixa tensão de oxigênio, resultam em melhores taxas de gestação em comparação com aqueles produzidos com alta tensão de oxigênio. Portanto, é possível formular a hipótese que o sistema de produção in vitro leva à alteração nos níveis de ERBB2 e ERBB3 em embriões bovinos, e que esse efeito é mediado através do miR-199a em resposta ao estresse oxidativo. Assim, parte do objetivo deste trabalho foi determinar o efeito do estresse oxidativo sobre a expressão do miR-199a, isoformas miR-199a-3p e miR199-5p, durante o desenvolvimento embrionário bovino e determinar se a alteração destes miRNAs regula a expressão dos genes alvo ERBB2 e ERBB3 e da proteína ERBB2.

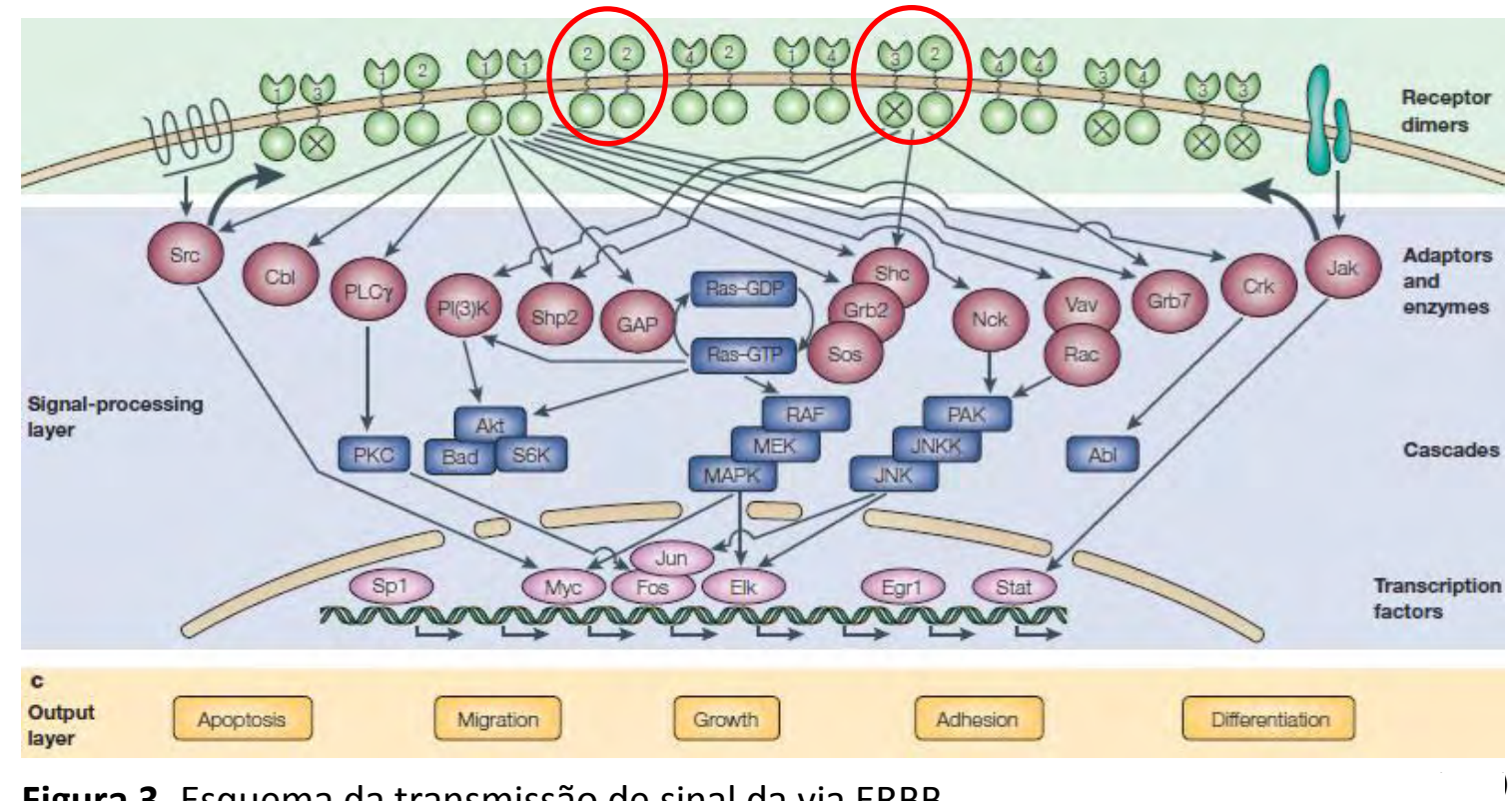

Figura 3. Esquema da transmissão de sinal da via ERBB. 


\section{Hipóteses}

\subsection{Experimento I}

A alta tensão de oxigênio é capaz de elevar os níveis de EROs, caracterizando uma condição de estresse oxidativo celular. Este estresse é responsável pela alteração da expressão do microRNA 199a e, consequentemente, dos genes alvo ERBB2 e ERBB3. Além disso, tais alterações podem ser revertidas pela suplementação de antioxidantes durante o cultivo in vitro.

\subsection{Experimento II}

O estresse oxidativo gerado pela alta tensão de oxigênio é capaz de alterar os níveis globais de metilação do DNA de blastocistos produzidos in vitro. Estas alterações são acompanhadas por mudanças nos padrões de expressão de miRNAs e de genes associados a resposta ao estresse oxidativo, proliferação e diferenciação celular, remodelação epigenética, apoptose, metabolismo e reconhecimento materno-fetal. A suplementação de antioxidantes no sistema de cultivo in vitro é capaz de prevenir as alterações dos miRNAs causadas pelo estresse oxidativo.

\subsection{Experimento III}

O estresse oxidativo induzido pela condição de alta tensão de oxigênio durante o desenvolvimento embrionário in vitro é capaz de alterar o padrão de secreção de exossomo e o seu conteúdo de miRNAs durante o cultivo in vitro. 


\section{Objetivos e Delineamento Experimental}

\subsection{Experimento I}

Objetivo geral: Validar que o modelo de cultivo em condições de alta tensão de oxigênio induz alterações nos níveis de EROs, promovendo o estresse oxidativo. Determinar o efeito do estresse oxidativo sobre a expressão das isoformas do miR-199a, transcritos dos genes alvo $E R B B 2$ e $E R B B 3$, e proteína ERBB2 em embriões bovinos produzidos por fertilização in vitro. Avaliar a eficácia da suplementação com antioxidantes para reverter as alterações de EROs, miRNAs e RNAm nos blastocistos produzidos in vitro.

\section{Objetivos específicos:}

- Determinar se a alta tensão de oxigênio (20\%) é capaz de aumentar os níveis de EROs gerando um estado de estresse oxidativo nos embriões bovinos produzidos in vitro, em comparação com embriões produzidos em baixa tensão de oxigênio (5\%);

- Comparar a expressão das isoformas do miR-199a (miR-199a-3p e miR-199a-5p), de seus genes alvo (ERBB2 e ERBB3) e proteína ERBB2 em blastocistos bovinos cultivados in vitro em alta ou baixa tensão de oxigênio;

- Determinar se as alterações no miR-199a, transcritos dos genes alvo (ERBB2 e ERBB3) e proteína ERBB2 geradas pelo estresse oxidativo podem ser revertidas pela suplementação com antioxidantes (cisteína e cisteamina) durante a maturação e parte do cultivo (D1 a D3) em blastocistos bovinos. 
Delineamento experimental:

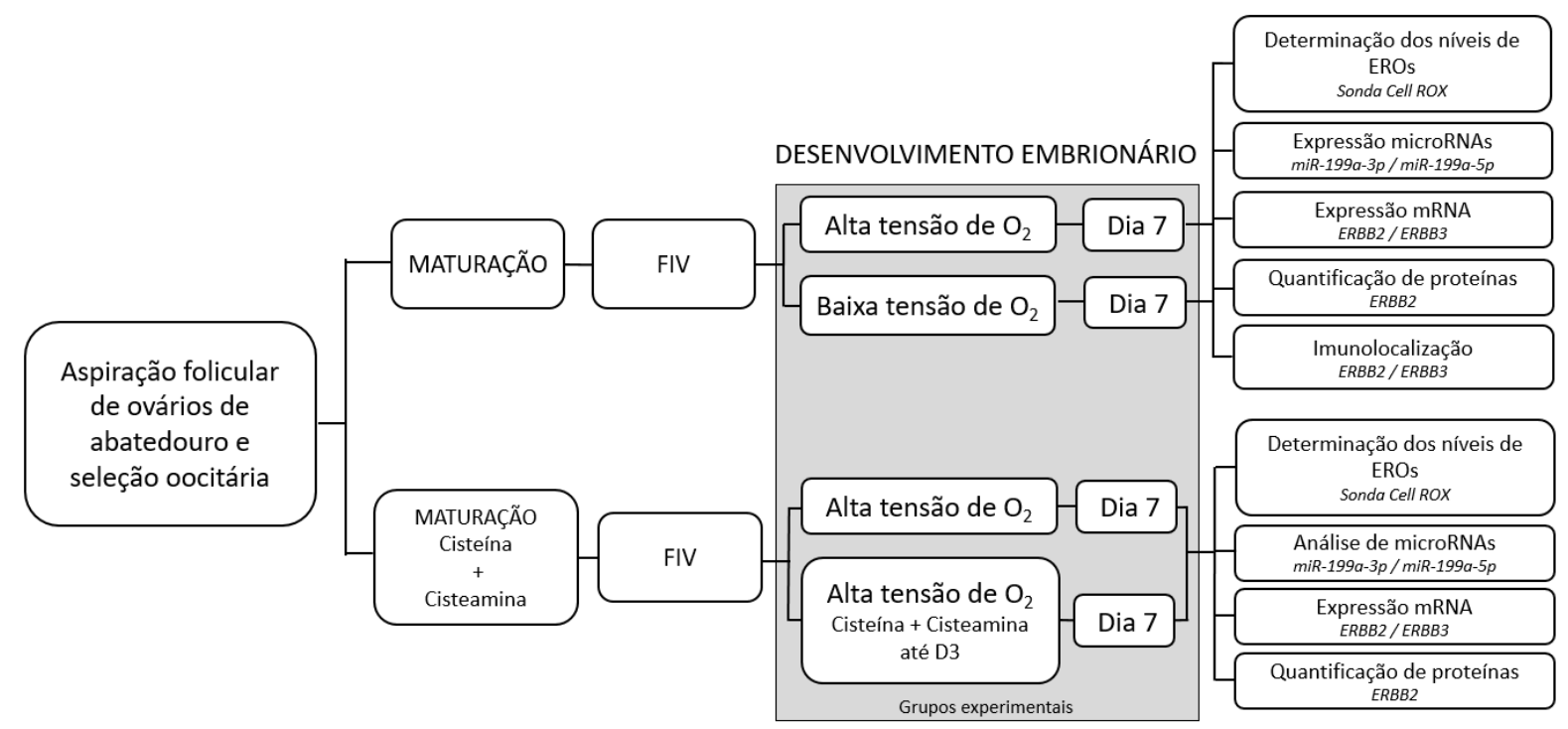

Figura 4. Delineamento do Experimento I. Os embriões foram cultivados em diferentes tensões de $\mathrm{O}_{2}$ (alta $20 \% \mathrm{O}_{2}$ e baixa $5 \% \mathrm{O}_{2}$ ), posteriormente foram desenvolvidos dois grupos adicionais cultivado em alta tensão de oxigênio na presença e ausência de suplementado com antioxidantes. As coletas dos blastocistos foram realizadas no dia 7 do desenvolvimento. As análises foram realizadas com pools de embriões otimizados para cada técnica, com no mínimo três repetições biológicas.

\subsection{Experimento II}

Objetivo geral: Determinar o efeito do estresse oxidativo gerado pela alta tensão de oxigênio nos níveis globais de metilação dos blastocistos bovinos. Avaliar as alterações de expressão de 96 RNAm e de 378 microRNAs causada pelo estresse oxidativo em embriões bovinos produzidos por fertilização in vitro. Investigar se as alterações observadas na expressão dos miRNAs podem ser revertidas pela suplementação do meio de cultivo com antioxidantes.

\section{Objetivos específicos:}

- Comparar os níveis de metilação global do DNA de blastocistos produzidos in vitro submetidos a condições de alta (20\%) ou baixa (5\%) tensão de oxigênio.

- Comparar a expressão dos RNAm de 96 genes em blastocistos produzidos in vitro com alta ou baixa tensão de oxigênio e determinar quais as principais funções biológicas afetadas pelo estresse oxidativo. 
- Determinar a expressão de 378 miRNAs e comparar as vias enriquecidas pelos miRNAs diferentemente expressos em blastocistos bovinos produzidos in vitro com alta ou baixa tensão de oxigênio.

- Comparar o cultivo de embriões em condições de alta tensão de oxigênio com a alta tensão suplementada com antioxidantes no meio de cultivo durante a MIV e parte do cultivo (D1 a D3), para determinar se a suplementação com antioxidante é capaz de reverter as alterações dos miRNAs associadas ao estresse oxidativo.

\section{Delineamento experimental:}

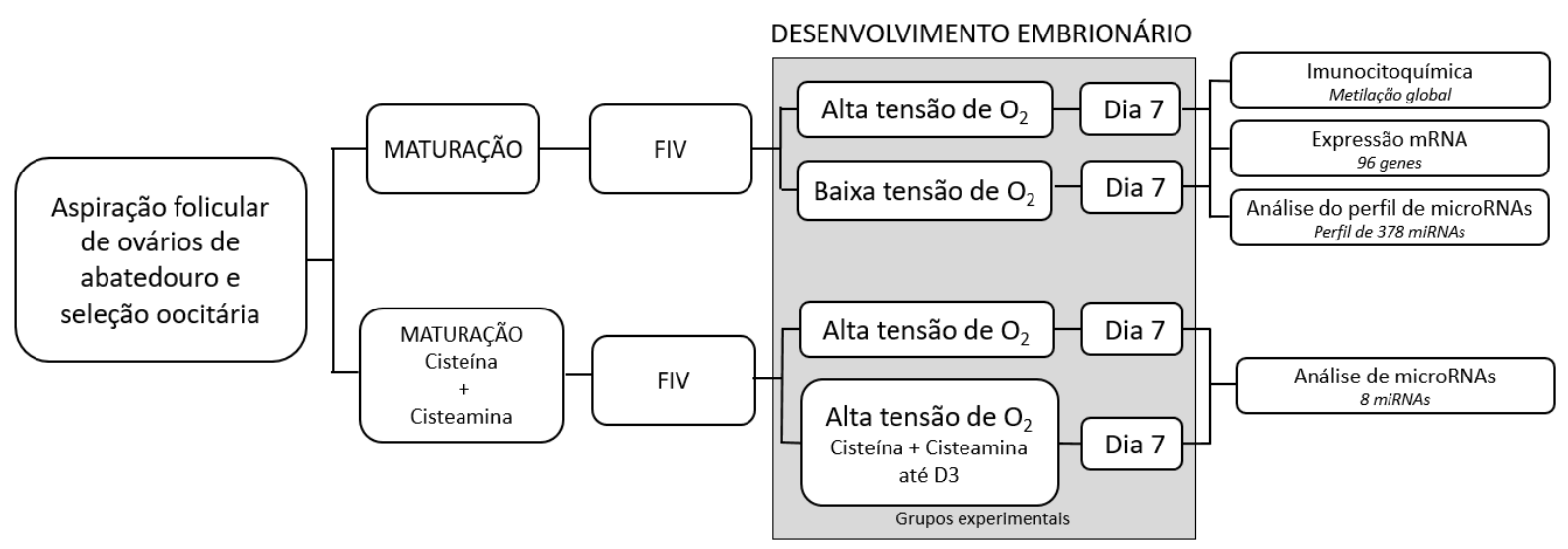

Figura 5. Delineamento do experimento do Experimento II. Os embriões foram cultivados em diferentes tensões de $\mathrm{O}_{2}$ (alta - $20 \% \mathrm{O}_{2}$; e baixa - $5 \% \mathrm{O}_{2}$ ), posteriormente foram desenvolvidos dois grupos adicionais cultivado em alta tensão de oxigênio na presença e ausência de suplementado com antioxidantes. As coletas dos blastocistos foram realizadas no dia 7 do desenvolvimento. As análises foram realizadas com pools de embriões otimizados para cada técnica, com no mínimo três repetições biológicas.

\subsection{Experimento III}

Objetivo geral: Determinar o efeito do estresse oxidativo sobre o padrão de secreção de exossomos e o perfil de microRnAs dos mesmos, presentes no meio de cultivo durante o cultivo in vitro de embriões bovinos nos dias 3 e 7 do desenvolvimento. 


\section{Objetivos específicos:}

- Comparar o tamanho e a concentração de exossomos no meio de cultivo de embriões bovinos produzidos in vitro com alta $\left(20 \% \mathrm{O}_{2}\right)$ ou baixa $\left(5 \% \mathrm{O}_{2}\right)$ tensão de oxigênio, nos dias 3 e 7 do desenvolvimento.

- Comparar a expressão dos miRNAs dos exossomos presentes no meio de cultivo de embriões bovinos cultivados em alta e baixa tensão de oxigênio.

- Determinar as principais vias enriquecidas pelos miRNAs diferentemente expressos nos exossomos do meio de cultivo de embriões bovinos em atmosferas de cultivo de alta e baixa tensão de oxigênio.

- Comparar a expressão dos miRNAs e as vias enriquecidas pelo conteúdo de miRNAs dos exossomos com a expressão dos miRNAs nos blastocistos produzidos em condições in vitro de alta e baixa tensão de oxigênio.

\section{Delineamento experimental:}

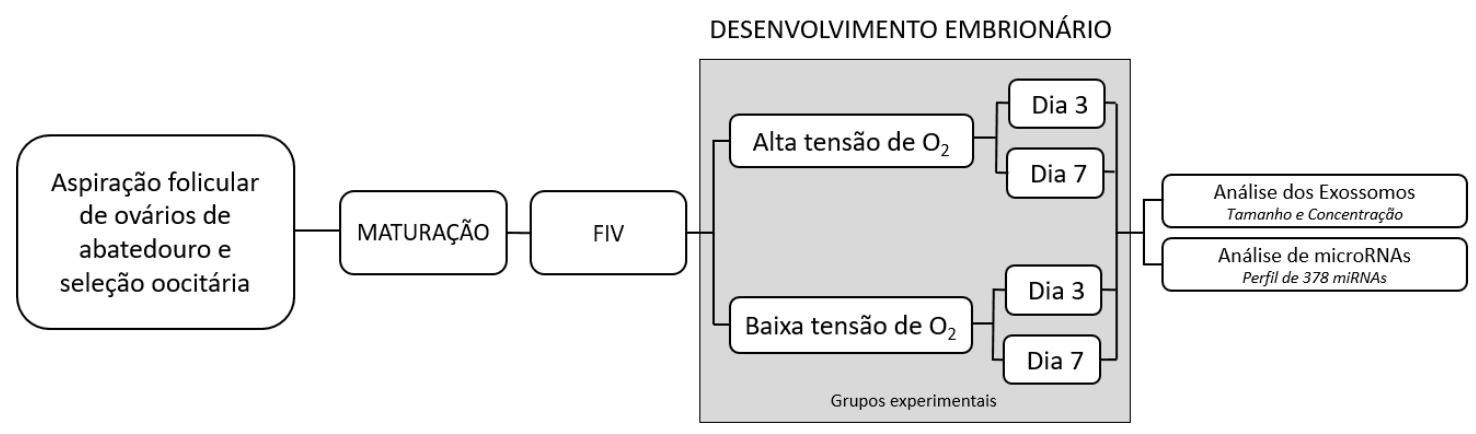

Figura 6. Delineamento do Experimento III. Os embriões produzidos em Alta $\mathrm{O}_{2}$ e Baixo $\mathrm{O}_{2}$ no Experimento I tiveram os meios de cultivo coletados no D3, durante o procedimento de feeding, e em D7. As amostras foram agrupadas em pools de 3 repetições para isolamento e análise dos exossomos e seu conteúdo de miRNAs. As análises estatísticas foram realizadas com 3 repetições para cada grupo. 


\section{Material e Métodos}

\subsection{Local dos experimentos e reagentes}

O estudo foi realizado durante os anos de 2015-2017 no Laboratório de Morfofisiologia Molecular e Desenvolvimento (LMMD) do Departamento de Medicina Veterinária, da Faculdade de Zootecnia e Engenharia de Alimentos (FZEA) da Universidade de São Paulo (USP) campus Fernando Costa, Pirassununga, São Paulo. O protocolo experimental foi aprovado pelo Comitê de Ética em Pesquisa (CEP-FZEA), sob o protocolo número 5763200215.

As análises de expressão gênica utilizando o HD Biomark (Fluidigm) foram feitas no Laboratório de Fitomedicamentos Farmacologia e Biotecnologia (FitoFarmaTec) do Departamento de Farmácia, do Instituto de Biociência de Botucatu da Universidade Estadual Paulista "Júlio de Mesquita Filho" (UNESP) campus Botucatu, São Paulo.

As análises de epifluorescência foram realizadas no Laboratório de Oncologia Comparada e Translacional (LOCT) do Departamento de Medicina Veterinária, da Faculdade de Zootecnia e Engenharia de Alimentos (FZEA) da Universidade de São Paulo (USP) campus Fernando Costa, Pirassununga, São Paulo.

As análises de confocal foram realizadas no Laboratório Multiusuário Microscopia Confocal (LMMC), da Faculdade de Medicina de Ribeirão preto (FMRP) da Universidade de São Paulo (USP) campus de Ribeirão Preto, São Paulo.

Os reagentes e meios para o cultivo foram adquiridos da Sigma-Aldrich (St. Louis, MO, EUA). Os reagentes para a deteç̧ão de EROs e PCR em tempo real foram adquiridos da Applied Biosystems (Foster City, CA, EUA) e da Fluidigm (South San Francisco, CA, EUA). Os reagentes para análise de microRNAs foram adquiridos da Qiagen (Venlo, Limburg, Holanda). Os reagentes para análises de Western Blotting foram adquiridos da Bio-Rad Laboratories (Hercules, CA, EUA). Os anticorpos foram adquiridos da LifeSpan BioSciences, Inc. (Seattle, WA, EUA), Applied Biosystems (Foster City, CA, EUA) e Santa Cruz Biotechnology (Santa Cruz, CA, EUA). 


\subsection{Produção in vitro de embriões}

Os ovários foram obtidos a partir de vacas mestiças abatidas com finalidade comercial na região de Pirassununga, São Paulo. O transporte dos ovários do frigorífico até o laboratório foi realizado em garrafas térmicas, com solução salina. Uma vez no laboratório, os ovários foram lavados e acondicionados em solução salina aquecida a $37^{\circ} \mathrm{C}$. Em seguida, os folículos ovarianos entre 3 e $6 \mathrm{~mm}$ de diâmetro foram aspirados, com auxílio de agulhas $18 \mathrm{G}$ acopladas a seringas de $10 \mathrm{~mL}$. O líquido folicular aspirado foi depositado em tubos cônicos de $50 \mathrm{~mL}$, que foram mantidos em repouso para sedimentação dos oócitos por 20 min. O sedimento foi visualizado em estereomicroscópio para seleção dos complexos cumulus oócitos (COCs), que posteriormente foram destinados à fertilização in vitro. Foram realizadas vinte e três coletas independentes distribuídas em um período de um ano.

Os COCs selecionados foram lavados em meio TCM199 suplementado com piruvato sódico $(22 \mu \mathrm{g} / \mathrm{mL})$, gentamicina $(50 \mu \mathrm{g} / \mathrm{mL})$ e $10 \%$ soro fetal bovino depletado de vesículas extracelulares por centrifugação. Os COCs de GI e Gll foram distribuídos no meio de maturação (MIV), composto de meio base TCM199 contendo: 26 mM de bicarbonato de sódio, $22 \mu \mathrm{g} / \mathrm{mL}$ de piruvato sódico, $50 \mu \mathrm{g} / \mathrm{mL}$ de gentamicina, $10 \%$ de soro fetal bovino depletado de vesículas, $0,5 \mu \mathrm{g} / \mu \mathrm{L}$ de hormônio folículo estimulante (FSH) (Folltropin ${ }^{\circledR}$, Bioniche Animal Health, Belleville, ON, Canadá) e $5 \mathrm{U} / \mathrm{mL}$ de gonadotrofina coriônica humana (HCG, Vetecor ${ }^{\circledR} 5000$ U.I. Intervet, São Paulo, SP, Brasil). Pools de 20 a 25 COCs foram transferidos para gotas de $100 \mu \mathrm{L}$ do meio MIV, cobertas com óleo mineral estéril (Dow Corning Co., Midland, MI, EUA). As placas foram identificas e mantidas em incubadora a $38,5^{\circ} \mathrm{C}$ e $5 \%$ de $\mathrm{CO}_{2}$ em ar e alta umidade por 22 horas, finalizando o processo de maturação oocitária.

Os oócitos supostamente maturados (dia zero) foram lavados três vezes em meio de fertilização e transferidos para gotas do mesmo meio cobertas por óleo mineral estéril. 0 meio de fertilização foi composto de solução TL-stock acrescida de $50 \mu \mathrm{g} / \mathrm{mL}$ de gentamicina, $22 \mu \mathrm{g} / \mathrm{mL}$ de piruvato sódico, $40 \mu \mathrm{L} / \mathrm{mL}$ PHE (2 mM D-penicilamina, $1 \mathrm{mM}$ hipotaurina e $245 \mu \mathrm{M}$ epinefrina), $5 \mathrm{U} / \mathrm{mL}$ de heparina e $6 \mathrm{mg} / \mathrm{mL}$ BSA. O sêmen para a PIVE foi descongelado $\left(37^{\circ} \mathrm{C} / 30 \mathrm{~s}\right)$ e depositado em um gradiente de Percoll $45 \%$ e $90 \%$. $\mathrm{O}$ conteúdo foi centrifugado a $4500 \mathrm{rpm}$ por $7 \mathrm{~min}$, o sedimento suspenso foi removido para a adição de $500 \mu \mathrm{L}$ de meio de fecundação, seguindo uma nova centrifugação de 2500 rpm 
por 5 min. A concentração do espermatozoide foi ajustada para a concentração 5 mil espermatozoides por oócito, e depositado nas gotas de fertilização, nas quais os oócitos aguardavam. Os gametas foram coincubados em gotas de fertilização por 20 horas.

Após a fertilização, os prováveis zigotos foram sutilmente desnudados mantendo uma monocamada de células do cumulus para constituir o pseudococultivo durante o desenvolvimento. Posteriormente, os supostos zigotos foram distribuídos de modo equivalente em placas contendo gotas de meio SOFaaci suplementado com $50 \mu \mathrm{g} / \mathrm{mL}$ de gentamicina, $22 \mu \mathrm{g} / \mathrm{mL}$ de piruvato sódico, $5 \mathrm{mg} / \mathrm{mL}$ de BSA, e 2,5\% SFB depletado de microvesículas e exossomos. As placas foram incubadas em atmosfera controlada de $5 \%$ de $\mathrm{CO}_{2}$ em ar $\left(20 \% \mathrm{O}_{2}\right)$ e em $5 \%$ de $\mathrm{CO}_{2}+5 \% \mathrm{O}_{2}+90 \% \mathrm{~N}_{2}$. As coletas do meio de cultivo para isolamento dos exossomos foram realizadas no dia 3 do desenvolvimento, durante a realização do feeding, e no dia 7 do cultivo. Os embriões para análise foram coletados no dia 7 do cultivo, no estágio de blastocisto do desenvolvimento.

\subsubsection{Tratamento com antioxidantes}

Um grupo adicional foi tratado com antioxidantes. Os oócitos selecionados foram maturados com meio de maturação, descrito anteriormente, suplementado com 0,6 mM de cisteína (\#C7352) associado a $100 \mu$ M de cisteamina (\#C8397) (Sigma-Aldrich, St. Louis, MO, EUA) (grupo $\mathrm{C}+\mathrm{C}$ ) e incubados a $38,5^{\circ} \mathrm{C}$ e $5 \%$ de $\mathrm{CO}_{2}$ em ar por 22 horas (ROCHA-FRIGONI, 2016). O tratamento foi retirado durante a fertilização in vitro e reestabelecido no dia 1 do desenvolvimento até o dia 3, conforme descrito por Rocha-Frigoni et al. (2014). No dia 3 os embriões foram transferidos para uma placa nova com meio SOFaaci sem antioxidantes. Todo o desenvolvimento deste grupo foi realizado a $38,5^{\circ} \mathrm{C}$ e $5 \%$ de $\mathrm{CO}_{2}$ em ar. Os embriões foram coletados no estágio de blastocisto, no dia 7.

\subsubsection{Taxa de clivagem e de blastocistos}

As taxas de desenvolvimento embrionário foram avaliadas quanto a clivagem e desenvolvimento até o estágio de blastocisto. A análise da taxa de clivagem foi observada visualmente, com o auxílio de um estereomicroscópio, no momento do feeding e à primeira 
coleta de meio de cultivo no dia 3. A taxa de blastocisto também foi avaliada com o auxílio de um estereomicroscópio, concomitantemente à coleta do dia 7 do cultivo.

\subsection{Experimento I}

\subsubsection{Análise do conteúdo intracelular de EROs para avaliação do estresse oxidativo}

A fim de determinar a formação de EROs durante o estresse oxidativo no embrião cultivado in vitro, grupos de 10 blastocistos de quatro rotinas experimentais diferentes foram comparados. A análise foi realizada mediante a técnicas fluorimétricas em microscopia de epifluorescência utilizando a sonda Cell ROX Green (Molecular Probes). Os embriões foram corados com $1 \mathrm{mmol} / \mathrm{L}$ do Cell ROX Green, por 30 minutos, em uma temperatura de $37^{\circ} \mathrm{C}$ e, logo após, fixados em $4 \%$ paraformaldeído por 20 min. Os blastocistos foram lavados e colocados em lâminas para as análises de epifluorescência. As amostras foram analisadas na objetiva $40 \mathrm{X}$ e comprimento de onda de $488 \mathrm{~nm}$. As imagens foram analisadas a partir da quantificação da intensidade de florescência dos blastocistos, em escala de cinza, utilizando o programa ImageJ (NIH; http://rsb.info.nih.gov/ij/).

\subsubsection{Coleta e extração de RNA total das amostras}

Os blastocistos foram agrupados em pools de 10 embriões em $5 \mu \mathrm{L}$ de PBS, suplementado com $0,1 \%$ de polivinilpirrolidona (PVP), e imediatamente congeladas em nitrogênio líquido. As amostras de embriões foram submetidas ao tratamento com $700 \mu \mathrm{L}$ de QIAzol Lysis Reagent (Qiagen, Venlo, Limburg, Holanda) e $140 \mu \mathrm{L}$ de clorofórmio para separação das fases aquosa (RNAs) e orgânica (proteínas) por uma fina camada de DNA. A fase aquosa foi cuidadosamente coletada e purificada utilizando o miRNeasy ${ }^{\circledR}$ micro kit (50) (Qiagen, Venlo, Limburg, Holanda). As amostras extraídas foram quantificadas via espectrofotometria, com NanoDrop $2000^{\circledR}$ (Applied Biosystems, Foster City, CA, EUA). 


\subsubsection{Expressão do miR-199a}

As análises da expressão das isoformas do miR-199a (miR-199a-3p e miR-199a-5p) foram realizadas utilizando amostras de pool de 10 blastocistos para 7 repetições biológicas. A transcrição reversa do RNA em cDNA foi realizada com kit miScriptll RT (Qiagen, Venlo, Limburg, Holanda) utilizando o tampão HiFlex do kit e contendo $100 \mathrm{ng}$ do RNA total extraído. Os cDNAs tratados com tampão HiFlex permitiram a detecção tanto dos miRNAs maduros quando dos precursores. As reações de PCR em tempo real foram preparadas para um volume total de $6 \mu \mathrm{L}$ contendo $3 \mu \mathrm{L}$ de SYBR Green PCR Master Mix (\#1020722), 0,6 $\mu \mathrm{L}$ primer reverso Universal, $0,02 \mu \mathrm{L}$ de cDNA, 1,38 $\mu \mathrm{L}$ de água e $1 \mu \mathrm{L}$ de primer forward específico (Tabela S.1, Qiagen, Venlo, Limburg, Holanda). A análise prosseguiu utilizando o sistema QuantStudio6 Flex (Applied Biosystems, Foster City, CA, EUA). As condições dos ciclos de PCR foram: $95^{\circ} \mathrm{C}$ durante 15 min e 45 ciclos de $94^{\circ} \mathrm{C}$ durante $15 \mathrm{~s}, 55^{\circ} \mathrm{C}$ durante $30 \mathrm{~s}$ e $70^{\circ} \mathrm{C}$ durante $30 \mathrm{~s}$, seguido por uma análise da curva de dissociação para confirmar a amplificação de um ou dois produtos de cDNA uma vez que podem haver miRNAs precursores e maduros em uma mesma análise. A expressão dos miRNAs foi normalizada com a média geométrica do valor de $\mathrm{Ct}$ dos endógenos RNU43 snoRNA e Hm/MS/Ru U1 SnRNA.

A análise das vias enriquecidas pelos miRNAs foi realizada utilizando a base de dados mirBase (http://www.mirbase.org), para analisar a homologia da sequência entre o miRNA bovino e o miRNA humano, e o software DIANA TOOLS (http://diana.imis.athenainnovation.gr/) (Vlachos et al., 2015), que utiliza os miRNAs humanos para a investigação das possíveis vias enriquecidas. A validação da interação do miRNA com a 3'UTR equivalente dos genes alvo foi investigada com o software TargetScan (http://www.targetscan.org/) (Agarwal et al., 2015), utilizando a base de dados humana e bovina, e com eleição das interações com alto grau de conservação entre as espécies.

\subsubsection{Análise dos RNAm de ERBB2 e ERBB3}

Para o RT-PCR dos RNAm dos genes alvo, ERBB2 e ERBB3, a transcrição reversa foi realizada com High-Capacity cDNA Reverse Transcription Kit (Applied Biosystems Forster, City, CA, EUA) utilizando 100 ng do RNA total extraído dos blastocistos e purificado pelo 
miRNeasy ${ }^{\circledR}$ mini kit (50). As análises de RNAm ERBB2 e ERBB3 foram realizadas com 8 repetições biológicas, cada reação de $10 \mu \mathrm{L}$ do RT-PCR foi preparada com $5 \mu \mathrm{L}$ de SYBR ${ }^{\circledR}$ Green PCR Master Mix (\#4367659, Applied Biosystems, FosterCity, CA, EUA), 1,5 $\mu$ L de solução de primers forward e reverse, na concentração de 0,5 $\mu \mathrm{M}, 1 \mu \mathrm{L}$ de cDNA (10 ng de CDNA) e 2,5 $\mu \mathrm{L}$ de água. O PCR em tempo real foi realizado utilizando o sistema QuantStudio6 Flex (Applied Biosystems, FosterCity, CA, EUA), em microtubos para PCR MicroAmp ${ }^{\circledR}$ Fast Reaction Tubes (Applied Biosystems, FosterCity, CA, EUA). As condições dos ciclos de PCR foram: $95^{\circ} \mathrm{C}$ durante 15 min e 40 ciclos de $95^{\circ} \mathrm{C}$ por $15 \mathrm{~s}$ e $60^{\circ} \mathrm{C}$ por $1 \mathrm{~min}$, seguido por uma análise da curva de dissociação para confirmar a amplificação única de produtos de cDNA. A expressão dos RNAm foi normalizada com a média geométrica do valor de Ct dos endógenos PPIA e RPL15.

\subsubsection{Primers para RNAm dos genes alvo ERBB2 e ERBB3}

Os pares de primers para os RNAm dos genes alvo ERBB2 e ERBB3 foram desenhados com base nas sequencias disponíveis no banco de dados do genoma bovino publicado no Enseblr.org ${ }^{\circledR}$ (www.ensembl.org). Priorizou-se que cada sequência de primer compreendesse simultaneamente as regiões de dois exons da sequência alvo e se localizasse próximo à extremidade 3' do mRNA, de modo a aumentar a fidelidade para amplificação apenas das moléculas de RNAm. Uma vez definidas as possíveis regiões de interesse, os primers foram desenhados com auxílio do software Primer 3 Plus ${ }^{\circledR}$ (www.bioinformatics.nl).

Para definir qual o melhor par de primers foram realizadas análises através dos softwares: Prime BLAST ${ }^{\circledR}$ (blast.ncbi.nlm.nih.gov), que permite a identificação de hibridizações com regiões inespecíficas do genoma bovino; AutoDimer ${ }^{\circledR}$ (yellow.nist.gov), que viabiliza a análise de potencial para geração de dímeros e hairpins; e UCSC Genome Bioinformatics ${ }^{\circledR}$ (http://genome.ucsc.edu/), que possibilita testes de PCR in silico.

Os primers desenhados para o ERBB2 bovino foram forward: 5' CAGCCGGAATATGTGAACCA 3' e reverse: 5' TTtCCAGAGTGGAACCAGCA 3', e para ERBB3 forward: 5' GCCACAGCCTGCTTACTCCT 3' e reverse: 5' CCGGGAGGAGGTACCTTTG 3'. Os pares de primers produziram amplicons curtos de 100 e 110 bases nitrogenadas, respectivamente, para ERBB2 e ERBB3. Os primers endógenos escolhidos foram os genes PPIA e RPL15 (MACABELLI et al., 2014). 


\subsubsection{Curva de eficiência dos primers}

Os primers foram testados no RT-PCR para uma diluição seriada de amostra, de modo a gerar uma curva, que permitiu o cálculo da eficiência do primer, através da fórmula: $\mathrm{E}=\left(10^{\frac{-1}{-y}}-1\right) \times 100$. A curva de diluição teve 5 pontos com concentrações seriadas de amostra (20 ng, 10 ng, 5 ng, 2,5 ng e 1,25 ng de RNA). As eficiências entre 90 e 110\% foram associadas a primers adequados.

Para a reação de RT-PCR padronizada, os primers apresentaram eficiências satisfatórias de 94,79\% (ERBB2), 99,54\% (ERBB3), 105,25\%\% (PPIA) e 101,11\% (RPL15; Figura 7).

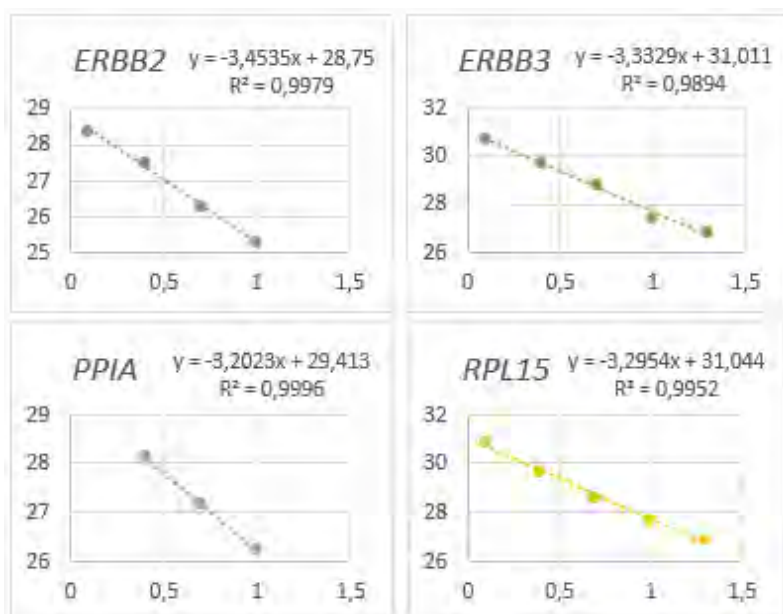

Figura 7. Os gráficos de pontos representam as curvas de eficiência dos primers para os genes candidatos ERBB2 (azul) e ERBB3 (verde), e genes endógenos PPIA (cinza) e RPL15 (verde). A equação da reta e o valor do coeficiente de determinação da regressão linear $\left(R^{2}\right)$ são apresentados para os respectivos genes. Nos gráficos, o eixo $X$ representa o log das diluições utilizadas e o eixo y representa os valores de Ct encontrados nas reações de Real Time RT-PCR.

\subsubsection{Sequenciamento dos amplicons}

Os amplicons gerados após a reação de RT-PCR foram encaminhados para sequenciamento dos pares de base após purificação do produto de RT-PCR com o kit QIAquick ${ }^{\circledR}$ PCR Purification (Qiagen, Venlo, Limburg, Holanda). As sequências resultantes do sequenciamento foram analisadas através do software Prime BLAST ${ }^{\circledR}$ 
(blast.ncbi.nlm.nih.gov), que identificou se os segmentos sequenciados correspondiam à regiões específicas do genoma bovino nos quais os primers foram desenhados (Figura 8).

\section{ERBB2}

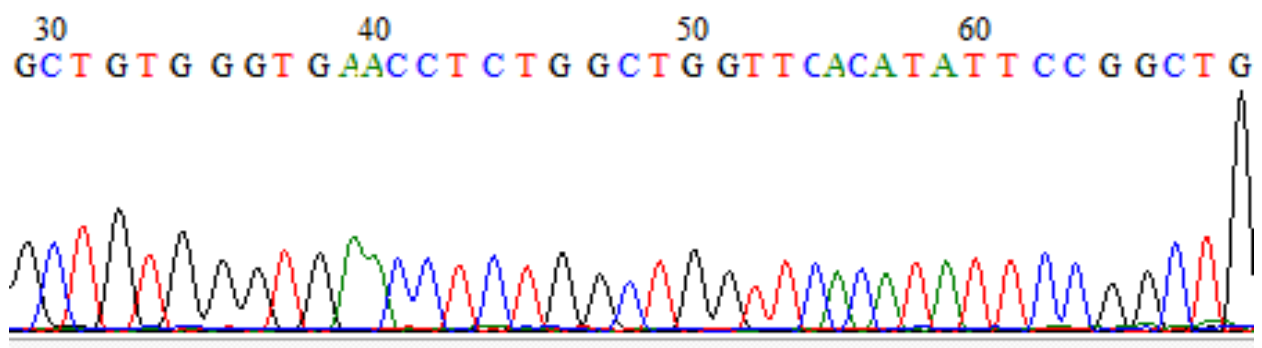

\section{ERBB3}

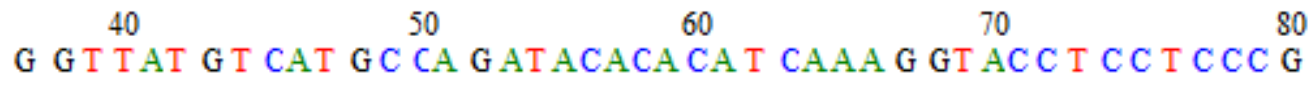

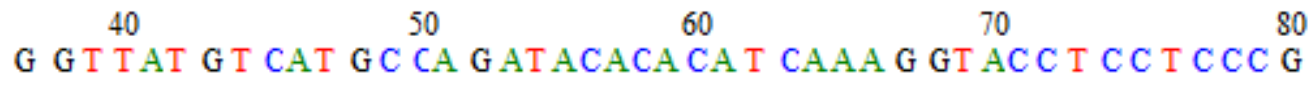

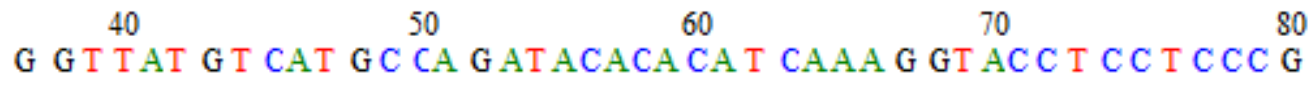

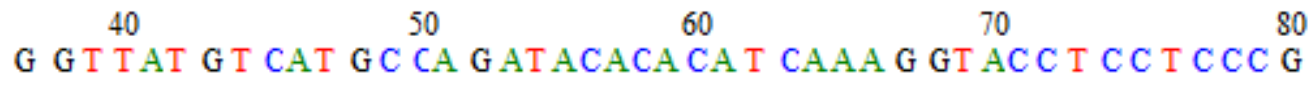

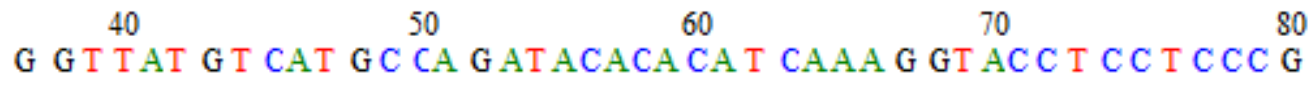

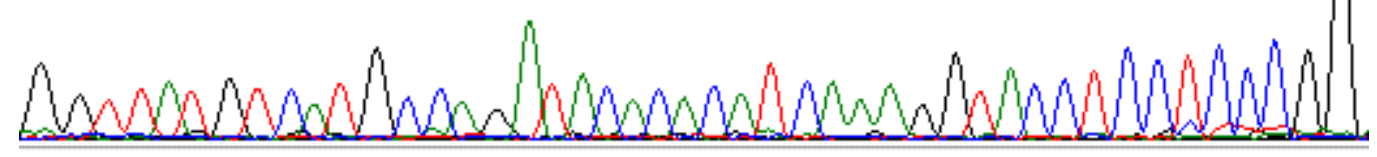

Figura 8. Resultado do sequenciamento para os transcritos ERBB2 e ERBB3. As sequências foram analisadas através do software Prime BLAST e apresentaram 100\% de homologia com os transcritos de interesse.

Os resultados do sequenciamento demonstram que os primers amplificam os segmentos corretos dos transcritos de interesse.

\subsubsection{Níveis proteicos do ERBB2}

A proteína ERBB2 foi analisada de forma quantitativa, pelo método de Western Blotting para 6 repetições biológicas. Pools de 25 embriões, submetidos à extração com tampão de lise RIPA (colocados na amostra na proporção de 1:3 e constituído por $50 \mathrm{mM}$ de Tris $\mathrm{HCl}, 150 \mathrm{mM}$ de $\mathrm{NaCl}, 1 \%$ de Triton $\mathrm{x}-100,0,5 \%$ de desoxicolato de sódio e $0,1 \%$ de dodecil sulfato de sódio - SDS) e incubados overnight a $-80^{\circ} \mathrm{C}$. As amostras foram submetidas ao tratamento (1:3) com solução 1:10 de 4X Laemmli Sample Tampão (\#1610747) e $\beta$ Mercapto (M7154) e aquecidos a $98^{\circ} \mathrm{C}$ por $5 \mathrm{~min}$, para desnaturação das formas complexas das proteínas. 
As proteínas foram aplicadas no Mini-PROTEAN ${ }^{\circledR}$ TGX Gels (\#456-1033) ainda aquecidas e, posteriormente, submetidas a uma diferença de potencial elétrico em tampão de corrida 10x Tris/Tricine/SDS Running Buffer (\#1610744). Logo em seguida, as proteínas foram eletrotransferidas para uma membrana de fluoreto de polivinilideno (PVDF), através de um sistema Trans-Blot ${ }^{\circledR}$ Turbo $^{\mathrm{TM}}$ Transfer Pack (\#170-4156) e transferência semi-seca com equipamento Trans-Blot ${ }^{\circledR}$ Turbo $^{\mathrm{TM}}$ Transfer System (Bio-Rad Laboratories, Hercules, CA, EUA).

As membranas foram bloqueadas em solução de tampão TBST $(10 \mathrm{mM}$ Tris-HCL (pH 7,5) $150 \mathrm{mM} \mathrm{NaCl}$ e 0,05\% Tween-20) com 5\% de BSA, por 1h. Posteriormente, foram marcadas com anticorpo primário ERBB2 (1:1.000, LS-A9398, LifeSpan BioSciences, Seattle, WA, EUA), a $4^{\circ} \mathrm{C}$ overnight. Em seguida, as membranas foram submetidas a três lavagens sequenciais com tampão TBST e incubadas com anticorpos secundários, anti-coelho (1:1.000, \#A0545, Sigma-Aldrich, St. Louis, MO, EUA) por 1h em temperatura ambiente. 0 excesso de anticorpo foi lavado com TBST, e as bandas específicas foram reveladas por quimioluminescência utilizando kit Amersahm ${ }^{\text {TM }}$ ECL $^{\text {TM }}$ Prime Western Blotting Detection Reagent (GE Healthcare, Little Chalfont, HP7, GB), de acordo com as normas do fabricante. As membranas foram reveladas com auxílio do transmissor Molecular Imager $^{\circledR}$ GelDoc $^{\mathrm{TM}}$ (Bio-Rad Laboratories, Hercules, CA, EUA). O controle positivo para o anticorpo primário ERBB2 foi um pool de amostras de carcinomas de mama caninos. O anticorpo endógeno escolhido foi a beta-actina (1:50.000, \#A3854, Sigma-Aldrich, St. Louis, MO, EUA).

\subsubsection{Imunocitoquímica ERBB2 e ERBB3 em blastocistos bovinos}

No dia 7 do desenvolvimento, durante a coleta das amostras, pools de 3-7 blastocistos foram fixados em 4\% de paraformaldeído por $20 \mathrm{~min}$, e estocados em PBS livre de $\mathrm{Mg}$ e $\mathrm{Ca}$ a $4^{\circ} \mathrm{C}$. A análise de imunocitoquímica foi realizada com pools de 3 blastocistos de 3 rotinas diferentes, por grupo, para localização das proteínas ERBB2 e ERBB3 nos blastocistos bovinos.

Os embriões foram permeabilizados com solução de PBS acrescido de 0,5\% de saponina por $10 \mathrm{~min}$, seguidos por lavagem em PBS e bloqueio com solução de PBS, 1\% de BSA, 0,3 M de glicina e 0,1\% de Tween 20 por $30 \mathrm{~min}$. Os blastocistos foram incubados, de acordo com cada grupo, com os anticorpos primários ERBB2 (1:100, LS-A9398) e ERBB3 (1:100, LS-C4251) diluídos em PBS com $1 \%$ de BSA e $0,1 \%$ de Tween 20 , overnight a $4^{\circ} \mathrm{C}$. Na 
sequência, os embriões foram lavados em PBS e incubados com anticorpos secundários (1:250) anti-coelho (\#A11036) e anti-camundongo IgGs (\#A11029) (Applied Biosystems, Foster City, CA, EUA) diluídos em PBS com 1\% de BSA e 0,1\% de Tween 20, respectivamente, para ERBB2 e ERBB3, por 1h em temperatura ambiente. Para cada grupo foi separado um blastocisto controle, que não foi submetido à incubação com o anticorpo primário.

Posteriormente, todos os grupos foram incubados com corante Hoechst (\#33342) por 15 min, para identificação de núcleo. Os blastocistos foram lavados e colocados em lâminas para as análises de epifluorescência. As amostras foram analisadas na objetiva 40X e avaliadas em comprimento de onda de $568 \mathrm{~nm}$ para o ERBB2 e $488 \mathrm{~nm}$ para ERBB3.

\subsubsection{Suplementação do meio de cultivo com antioxidantes}

No intuito de determinar a eficácia da suplementação do meio de cultivo com antioxidantes em reverter os efeitos do estresse oxidativo para os níveis de EROs, um grupo foi estimulado para a produção do antioxidante glutationa através da suplementação do meio de maturação com cisteína e cisteamina no grupo alto $\mathrm{O}_{2}(\mathrm{C}+\mathrm{C})$, mantendo para cada rotina um grupo controle sem tratamento exposto às mesmas condições de alta tensão de oxigênio grupo alto $\mathrm{O}_{2}$ (Ctr). A suplementação foi realizada conforme descrito no item 5.2.1. O tratamento foi validado pela técnica de fluorimetria para deteç̧ão de EROs utilizando a sonda Cell ROX Green (Molecular Probes) e analisado em microscopia de epifluorescência na objetiva 40X e avaliadas com comprimento de onda de $488 \mathrm{~nm}$, conforme descrito no item i. A análise foi realizada com 32 e 22 blastocistos, respectivamente cultivados em alta tensão na ausência e presença do tratamento $C+C$, oriundos de três rotinas experimentais diferentes.

O potencial da suplementação com cisteína e cisteamina em reverter as alterações do estresse oxidativo observados nos miR-199a-3p e miR-199a-3p expressos nos blastocistos cultivados em alta e baixa tensão de oxigênio, foi avaliado com pools de 10 blastocistos para 4 repetições biológicas. A extração do RNA total das amostras ocorreu conforme descrito anteriormente no item 5.3.2. deste experimento. Os processos de transcrição reversa e PCR em tempo real para as isoformas do miR-199a foram realizadas conforme descrito no item 5.3.3. deste experimento. A expressão dos miRNAs foi normalizada com a média geométrica do valor de Ct dos endógenos RNU43 snoRNA e Hm/MS/Ru U1. 
A capacidade do tratamento $\mathrm{C}+\mathrm{C}$ em reverter as alterações do estresse oxidativo sobre a expressão proteica do receptor ERBB2 foi analisada por Western Blotting com pools de 25 blastocistos, conforme descrito no item 5.3.5. deste experimento. A análise foi realizada com seis rotinas experimentais diferentes.

\subsection{Experimento II}

\subsubsection{Metilação global em blastocistos bovinos}

Os níveis globais de metilação do DNA foram determinados por imunomarcação de 5-mC em embriões produzidos em alta e baixa tensão de oxigênio. Os blastocistos, previamente fixados em $4 \%$ de paraformaldeído por $20 \mathrm{~min}$, foram agrupados em pools de 12 embriões, de 6 rotinas diferentes, por grupo, e os níveis de marcação para 5-mC foram obtidos por microscopia confocal.

Os embriões foram permeabilizados com solução de PBS acrescido de 0,5\% de saponina por 10 min, seguidos por lavagem em PBS, desnaturação do DNA com $4 \mathrm{~N}$ de ácido clorídrico por 12 min, neutralização com 100 mM de solução Tris $\mathrm{HCl}$ por 20 min e bloqueio com solução de PBS, $1 \%$ de BSA e 0,3 M de glicina por 1 hora. Os blastocistos foram incubados com o anticorpo primário para 5-metilcitidina (1:500, \#SC56615, Santa Cruz Biotechnology, Santa Cruz, CA, EUA), de acordo com cada grupo, overnight a $4^{\circ} \mathrm{C} . \mathrm{Na}$ sequência, os embriões foram lavados em PBS e incubados com anticorpo secundário anticamundongo IgGs (1:500, \#A11029, Applied Biosystems, FosterCity, CA, EUA), por $1 \mathrm{~h}$ em temperatura ambiente. Para cada grupo foi separado um blastocisto controle, que não foi submetido à incubação com o anticorpo primário. Os blastocistos foram lavados e colocados em lâminas. As análises foram realizadas por microscopia confocal, em equipamento SP5 da Leica (Leica Microsystems, Wetzlar, WZ, Alemanha), através da objetiva 40X em imersão à óleo. As amostras foram excitadas com o laser HeNe 543, em emissão de 590 a 630 nm, sendo 5 cortes por embrião. As imagens foram analisadas a partir de 5 blastômeros por corte utilizando o programa ImageJ (NIH; http://rsb.info.nih.gov/ij/). 


\subsubsection{Níveis de transcritos gênicos em blastocistos}

As análises de expressão de 96 RNAm foi realizada por qPCR utilizando o sistema de microfluídica Biomark HD (Fluidigm, South San Francisco, CA, EUA) para 8 repetições biológicas de embriões cultivados em alta ou baixa tensão de oxigênio (Tabela S.2). O RNA total de oito pools de 10 blastocistos foi extraído e purificado pelo miRNeasy ${ }^{\circledR}$ mini kit (50) conforme descrito no item 5.3.2. do experimento I. A transcrição reversa foi realizada com High-Capacity cDNA Reverse Transcription Kit (Applied Biosystems Foster, City, CA, EUA) utilizando $100 \mathrm{ng}$ do RNA total. Aproximadamente 1,25 $\mu \mathrm{L}$ de cDNA $(5 \mathrm{ng} / \mu \mathrm{L})$ da reação de transcrição foi submetida ao processo de pré-amplificação sequência específica, com 1,25 $\mu \mathrm{L}$ de mix Taqman $^{\circledR}$ Assay e 2,5 $\mu \mathrm{L}$ de TaqMan PreAmp Master Mix (\#4391128, Applied Biosystems), sob condições de ciclagem de $95^{\circ} \mathrm{C}$ por $10 \mathrm{~min}, 95^{\circ} \mathrm{C}$ por $15 \mathrm{~s} \mathrm{e} 14$ ciclos de $60^{\circ} \mathrm{C}$ por 4 min, para ativação, desnaturação e anelamento, respectivamente.

As análises dos 96 transcritos foram realizadas em reação de $10 \mu \mathrm{L}$ para o sistema Biomark HD foi preparada com 2,25 $\mu \mathrm{L}$ de cDNA (produto da pré-amplificação), 2,5 $\mu \mathrm{L}$ de TaqMan Universal PCR Master Mix (2X, Applied Biosystems, City, CA, EUA) e 0,25 $\mu \mathrm{L}$ de 20X GE Sample Loading Reagent (Fluidigm, South San Francisco, CA, EUA); e $5 \mu \mathrm{L}$ de solução para o ensaio com 2,5 $\mu \mathrm{L}$ de 20X TaqMan Gene Expression Assay (Applied Biosystems, City, CA, EUA) e 2,5 $\mu \mathrm{L}$ de $2 X$ Assay Loading Reagent (Fluidigm, South San Francisco, CA, EUA). Os

dados foram coletados com o chip 96.96 Dynamic Array ${ }^{\mathrm{TM}}$ Integrated Fluidic Circuits (Fluidigm, South San Francisco, CA, EUA). O protocolo de ciclagem utilizado no sistema Biomark HD foi o TaqMan GE 96x96 Standard, que consiste em um estágio Thermal Mix $\left(50^{\circ} \mathrm{C}\right.$ por $2 \mathrm{~min}, 70^{\circ} \mathrm{C}$ por $20 \mathrm{~min}$ e $25^{\circ} \mathrm{C}$ por $10 \mathrm{~min}$ ) seguido por um estágio de aquecimento Hot Start $\left(50^{\circ} \mathrm{C}\right.$ por $2 \mathrm{~min}$ e $95^{\circ} \mathrm{C}$ por $\left.10 \mathrm{~min}\right)$ e 40 ciclos de $95^{\circ} \mathrm{C}$ por $15 \mathrm{~s} \mathrm{e} 60^{\circ} \mathrm{C}$ por $60 \mathrm{~s}$, para desnaturação, anelamento do primer e extensão. Amostras com valor de Ct maior que 35 foram descartadas. Os valores de Ct bruto dos 96 transcritos foram normalizados pela média geométrica do valor de Ct dos endógenos PPIA, GAPDH e ACTB.

\subsubsection{Expressão do perfil de miRNAs para blastocistos bovinos}

A expressão de 378 miRNAs foi investigada por PCR em tempo real a partir de pools de 10 blastocistos de 3 repetições biológicas cultivadas em alta ou baixa tensão de oxigênio. 
As reações de extração, transcrição reversa e PCR foram realizadas, respectivamente, de acordo com o descrito nos itens 5.3.2. e 5.3.3. do experimento I (Tabela S.1). Em seguida, foi realizada a análise da curva de dissociação para confirmar a amplificação miRNAs precursores e maduros. Amostras que apresentavam valor de $\mathrm{Ct}$ a cima de 35 também foram descartadas. A expressão dos miRNAs foi normalizada com a média geométrica do valor de $\mathrm{Ct}$ dos endógenos RNU43 snoRNA, Hm/MS/Ru U1 snRNA e bta-miR-99b. A análise de bioinformática para identificação das vias enriquecidas para os miRNAs encontrado diferentemente expressos foi realizada de acordo com a descrição do item 5.3.3. do experimento I.

Adicionalmente, foram determinados os níveis de expressão relativa de oito miRNAs (bta-miR-34c, bta-miR-19a, bta-miR-210, bta-miR-140, bta-miR-1260b, bta-miR-378b, btamiR-22-5p e bta-miR-155) em pools de 10 blastocistos de 4 repetições biológicas cultivadas em alta tensão de oxigênio na ausência ou presença de antioxidantes (conforme descrito abaixo no item 5.2.1). As reações de extração, transcrição reversa e PCR foram realizadas, respectivamente, de acordo com o descrito nos itens 5.3.2. e 5.3.3. do experimento I. A análise dos resultados ocorreu conforme descrito anteriormente. A expressão dos miRNAs foi normalizada com a média geométrica do valor de $\mathrm{Ct}$ dos endógenos RNU43 snoRNA, $\mathrm{Hm} / \mathrm{MS} / \mathrm{Ru}$ U1 snRNA e bta-miR-99b.

\subsection{Experimento III}

As coletas do meio de cultivo para isolamento dos exossomos foram realizadas no dia 3 do cultivo in vitro de embriões bovinos em alta e baixa tensão de oxigênio, durante a realização do feeding; e no dia 7 do cultivo, após a coleta dos blastocistos. Imediatamente após a coleta os meios foram processados através de um protocolo de centrifugação de $300 \mathrm{G}$ por $10 \mathrm{~min}, 2.000 \mathrm{G}$ por $10 \mathrm{~min}$ e $16.500 \mathrm{G}$ por $30 \mathrm{~min}$, para separação e descarte de células e restos celulares remanescentes. Após o processamento os meios foram armazenados à $-80^{\circ} \mathrm{C}$.

Os meios de cultivo foram agrupados em pools de 3 rotinas. Os exossomos foram isolados após tratamento com reagente ExoQuick-TC (1:1, \#EXOQ20A1, System Biosciences, CA, EUA), overnight a $4^{\circ} \mathrm{C}$, e centrifugação a $1.500 \mathrm{G}$ por $30 \mathrm{~min}$. O pellet de exossomos foi 
ressuspendido em $50 \mu \mathrm{L}$ de PSB, dos quais $10 \mu \mathrm{L}$ foi direcionado para a análise do padrão de secreção e $40 \mu \mathrm{L}$ submetido ao processo de extração de RNA total.

\subsubsection{Padrão de secreção dos exossomos presentes no meio de cultivo de embriões bovinos nos dias 3 e 7}

O padrão de secreção dos exossomos foi analisado através do NanoSight NS300 (NanoSight, Slisbury, SP, GB) utilizando $10 \mu \mathrm{L}$ do pellet de exossomos isolado do meio de cultivo diluído em PBS na proporção 1:50. Foram analisados 3 pools de exossomos avaliados para cada grupo, alta e baixa tensão de oxigênio, para os dias 3 e 7 do desenvolvimento. 0 screen gain $^{1}$ da análise do NanoSight NS300 foi padronizada para 4,0 no dia 3 e 10,0 no dia 7. Não houve variação do screen gain dentro dos grupos. Para cada amostra o NanoSight NS300 gerou 5 vídeos de 30s, com os quais foram analisados os padrões de tamanho e concentração dos exossomos nos meios de cultivo de alta e baixa tensão de oxigênio, nos dias 3 e 7 do desenvolvimento.

\subsubsection{Perfil de microRnAs dos exossomos presentes no meio de cultivo de embriões bovinos nos dias 3 e 7}

As análises da expressão relativa de 378 miRNAs do conteúdo dos exossomos foram realizadas a partir de $40 \mu \mathrm{L}$ dos $50 \mu \mathrm{L}$ do pellet de exossomos isolado do meio de cultivo para 3 pools de meio de cultivo submetidos a alta ou baixa tensão de oxigênio. As amostras de isolados de exossomos foram submetidas ao tratamento com $700 \mu \mathrm{L}$ de QIAzol Lysis Reagent (Qiagen, Venlo, Limburg, Holanda) e $140 \mu \mathrm{L}$ de clorofórmio para separação das fases aquosa (RNAs) e orgânica (proteínas) por uma fina camada de DNA. A fase aquosa foi cuidadosamente coletada e purificada utilizando o miRNeasy ${ }^{\circledR}$ mini kit (50) (Qiagen, Venlo, Limburg, Holanda). As amostras extraídas foram quantificadas via espectrofotometria, com NanoDrop $2000^{\circledR}$ (Applied Biosystems, FosterCity, CA, EUA).

\footnotetext{
${ }^{1} O$ screen gain é uma configuração de imagem que determina a gama de intensidades de pixels capturadas pela câmera, regulando a saturação da fluorescência na imagem.
} 
A transcrição reversa do RNA em cDNA foi realizada com kit miScriptll RT (Qiagen, Venlo, Limburg, Holanda) utilizando o tampão HiFlex do kit e contendo 100 ng do RNA total extraído. Os cDNAs tratados com tampão HiFlex permitiram a detecção tanto dos miRNAs maduros quando dos precursores. As análises dos 378 miRNAs foram realizadas utilizando amostras de 3 pools de exossomos isolados do meio de cultivo por grupo (alta e baixa tensão de oxigênio), nos dias 3 e 7 do desenvolvimento, em reações de $6 \mu \mathrm{L}$ preparadas com $3 \mu \mathrm{L}$ de SYBR Green PCR Master Mix (Qiagen, Venlo, Limburg, Holanda), 0,6 $\mu \mathrm{L}$ primer reverso Universal (Qiagen, Venlo, Limburg, Holanda), 0,02 $\mu \mathrm{L}$ de cDNA, 1,38 $\mu \mathrm{L}$ de água e $1 \mu \mathrm{L}$ de primer forward específico (Qiagen, Venlo, Limburg, Holanda). As placas de 384 poços foram montadas manualmente e analisadas por RT-PCR utilizando o sistema QuantStudio6 Flex (Applied Biosystems, Foster City, CA, EUA). As condições dos ciclos de PCR foram: $95^{\circ} \mathrm{C}$ durante $15 \mathrm{~min}$ e 45 ciclos de $94^{\circ} \mathrm{C}$ durante $15 \mathrm{~s}, 55^{\circ} \mathrm{C}$ durante $30 \mathrm{~s}$ e $70^{\circ} \mathrm{C}$ durante $30 \mathrm{~s}$, seguido por uma análise da curva de dissociação para confirmar a amplificação de miRNAs precursores e maduros. As amostras que apresentaram valor de $\mathrm{Ct}$ a cima de 35 foram descartadas. Os valores de Ct bruto foram normalizados pela média geométrica do valor de Ct dos endógenos Hm/MS/Ru U1 snRNA e bta-miR-99b tanto para as amostras do D3 como para as do dia 7.

A análise das vias enriquecidas pelos miRNAs foi realizada utilizando a base de dados mirBase (http://www.mirbase.org), para analisar a homologia da sequência entre o miRNA bovino e humano, e o software DIANA TOOLS (Vlachos et al., 2015), que utiliza os miRNAs humanos para a investigação das possíveis vias enriquecidas.

\subsection{Análise dos Resultados}

Os resultados dos experimentos de desenvolvimento embrionário, níveis de EROs, expressão de miRNA e mRNA e metilação global foram comparadas utilizando Teste T Student. Os níveis de proteína foram comparados utilizando teste de Tukey para múltiplas comparações. Quando necessários os dados foram transformados matematicamente para log, como para as análises de EROs, expressão proteica e metilação global do DNA. As análises foram realizadas com auxílio do SAS e o nível de significância considerado foi de $5 \%$ em todos os experimentos. 


\section{Resultados}

\subsection{Experimento I}

\subsubsection{Taxa de clivagem e blastocisto}

As taxas de clivagem e blastocisto foram avaliadas em 23 rotinas independentes. Não houve diferença significativa entre os cultivos de alta e baixa tensão de oxigênio (Tabela 1).

Tabela 1. Médias e desvio padrão (DP) das taxas de clivagem e blastocistos de embriões bovinos produzidos em alta (20\%) e baixa (5\%) tensão de oxigênio.

\begin{tabular}{|c|c|c|c|c|c|c|}
\hline & No & Nc & $\begin{array}{c}\text { Taxa de } \\
\text { Clivagem } \\
\text { (média } \pm \text { DP) }\end{array}$ & $\mathrm{Nb}$ & $\begin{array}{c}\text { Taxa de } \\
\text { Blastocistos } \\
\text { (média } \pm \text { DP) }\end{array}$ & Taxa Total \\
\hline Alto $\mathrm{O}_{2}$ & 1.908 & 1.591 & $83,23 \% \pm 4,23$ & 485 & $27,24 \% \pm 10,99$ & $25,42 \%$ \\
\hline Baixo $\mathrm{O}_{2}$ & 1.872 & 1.557 & $82,92 \% \pm 6,31$ & 422 & $23,96 \% \pm 9,36$ & \\
\hline TOTAL & 3.780 & 3.148 & - & 907 & - & - \\
\hline
\end{tabular}

\subsubsection{Conteúdo intracelular de EROs para avaliação do estresse oxidativo}

Os níveis intracelulares de espécies reativas de oxigênio (EROs) foram determinados em 35 e 38 blastocistos cultivados em alta e baixa tensão de oxigênio, respectivamente (Figura 9). Os resultados foram analisados em unidades arbitrárias de fluorescência. O grupo desenvolvido sob alta tensão de $\mathrm{O}_{2}$ apresentou níveis maiores de EROs $(12,448 \pm 0,794)$ em relação ao grupo de baixa tensão de $\mathrm{O}_{2}(10,006 \pm 0,678$, considerando $p \leq 0,05)$. 

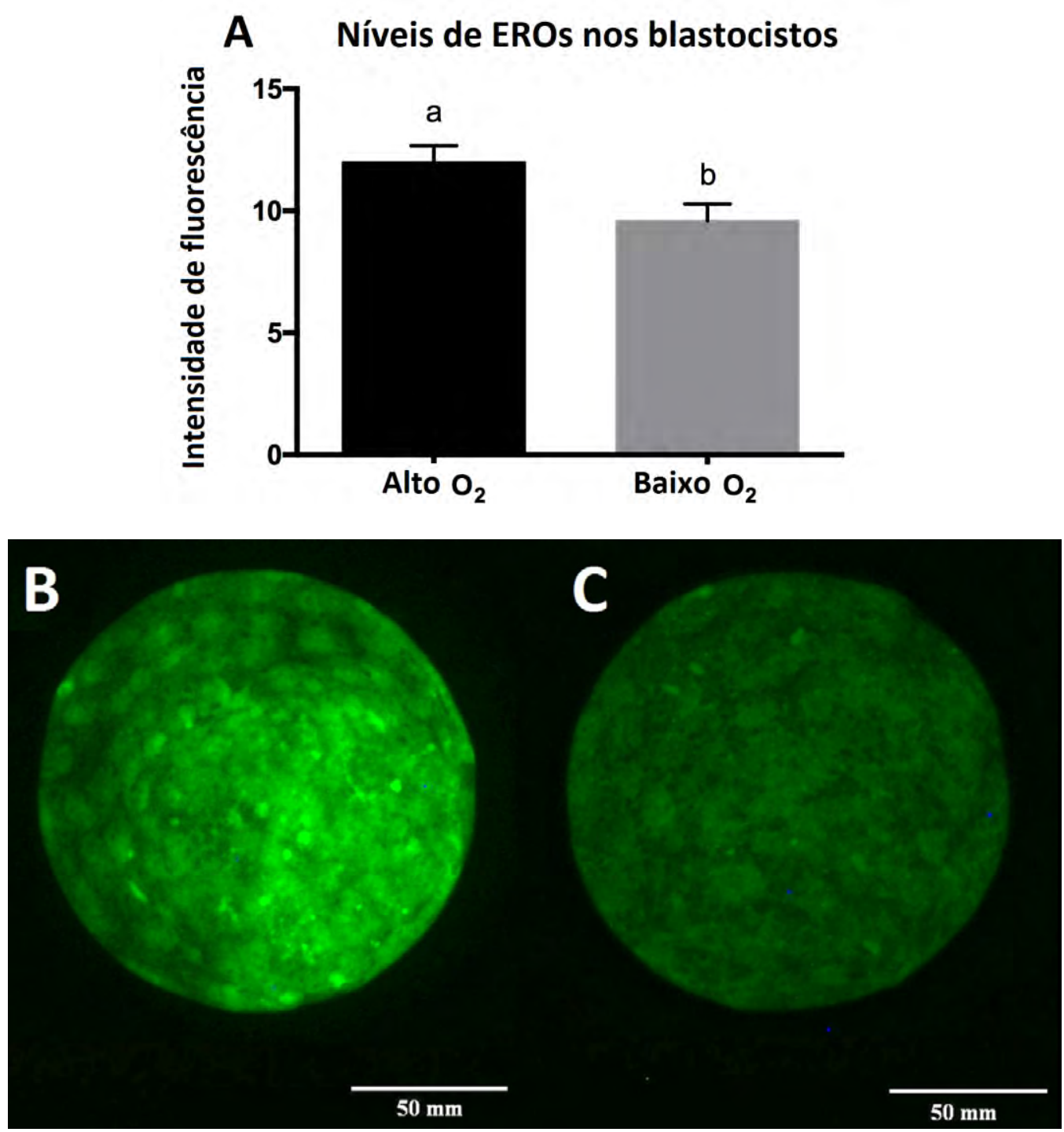

Figura 9. Níveis intracelulares de EROs (em unidades arbitrárias de fluorescência) em blastocistos bovinos produzidos em alta e baixa tensão de oxigênio (A). As barras do gráfico representam o erro padrão da média. Letras diferentes $(a, b)$ indicam diferença estatística significante $(p \leq 0,05)$. Fotomicrografias de epifluorescência de blastocistos produzidos em alta (B) e baixa (C) tensões de oxigênio e corados com CellROX Green (40x).

\subsubsection{Expressão do miR-199a}

Os resultados de expressão das isoformas do miR-199a demonstraram que o miR199a-3p não apresenta variação de expressão entre as amostras cultivadas em alta $(0,0000478 \pm 0,0000222)$ ou em baixa $(0,0000476 \pm 0,0000179$, considerando $p \leq 0,05)$ tensão de oxigênio. O miR-199a-5p, por sua vez, foi mais expresso na alta tensão $(0,0000482$ $\pm 0,0000193)$ de oxigênio em comparação com a baixa tensão $(0,0000305 \pm 0,00000305$, considerando $p \leq 0,05$ ) (Figura 10). 

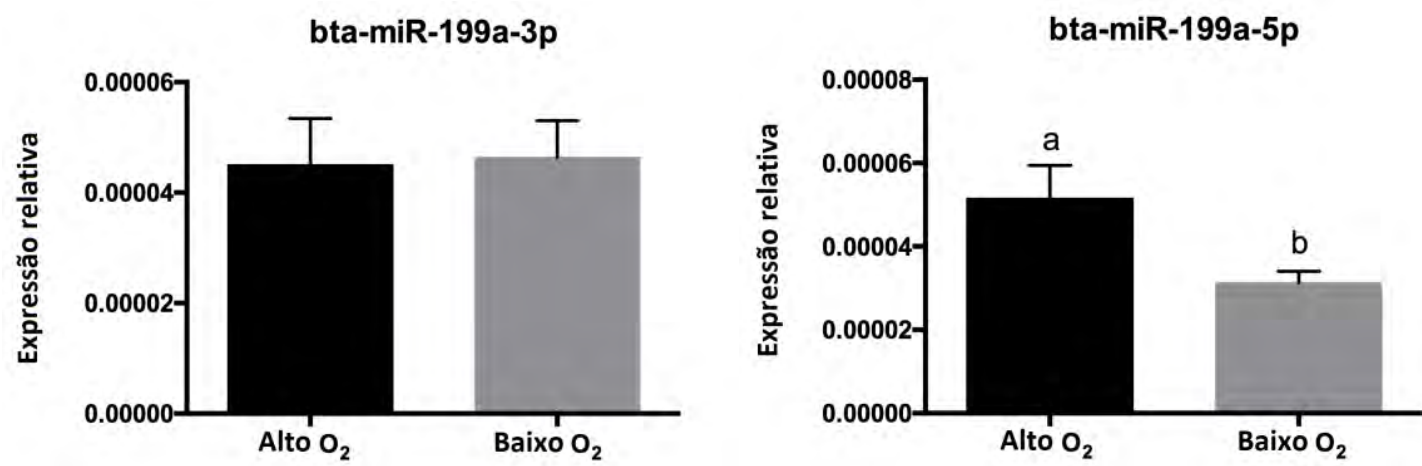

Figura 10. Expressão relativa das isoformas do miR-199a para blastocistos cultivados em alta ou em baixa tensão de oxigênio. As barras representam as médias e as barras de erros representam o erro padrão da média. Letras diferentes $(a, b)$ acima das barras indicam diferença significativa $(p \leq 0,05)$.

\subsubsection{Análise dos genes alvo ERBB2 e ERBB3}

Os resultados da expressão dos RNAm ERBB2 e ERBB3 não apresentaram diferença significativa entre os grupos de alta $(0,034 \pm 0,01$ e 0,029 $\pm 0,011$ para ERBB2 e ERBB3, respectivamente) e baixa $(0,029 \pm 0,009$ e 0,023 $\pm 0,006$ para ERBB2 e ERBB3, respectivamente, considerando $p \leq 0,05$ ) tensões de oxigênio (Figura 11).

ERBB2

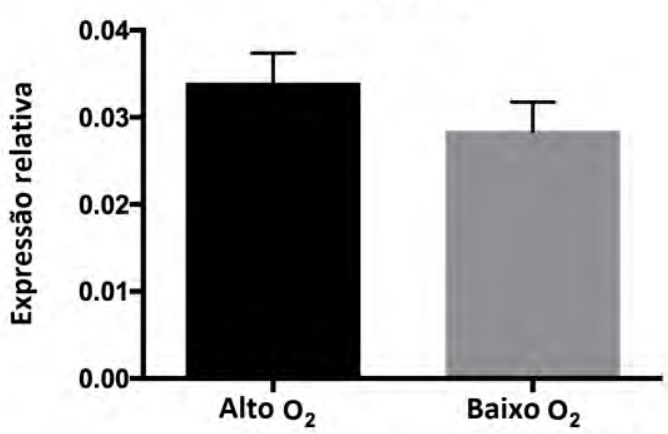

ERBB3

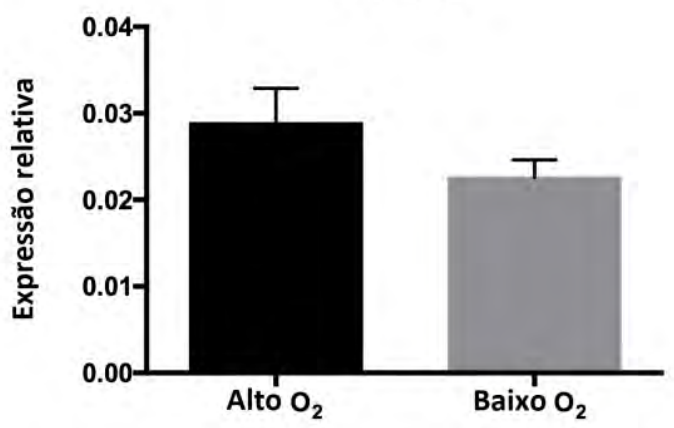

Figura 11. Expressão relativa dos transcritos ERBB2 e ERBB3 para os blastocistos cultivados em alta ou em baixa tensão de oxigênio. As barras representam as médias e as barras de erros representam o erro padrão da média. Letras diferentes $(a, b)$ acima das barras indicam diferença significativa $(p \leq 0,05)$.

A expressão proteica do ERBB2, foi numericamente superior nos blastocistos cultivados em alta tensão $(0,548 \pm 0,455)$ em comparação com a baixa tensão de oxigênio 
$(0,308 \pm 0,317$, considerando $p \leq 0,05)$, entretanto este valor não foi significativamente diferente (Figura 12A). Este estudo observou a presença de um padrão de 2 ou 3 bandas para o Western Blotting da proteína ERBB2 de modo semelhante ao reportado por Fock e colaboradores (2015) (Figura 12B).

\section{A Níveis de ERBB2 nos blastocistos}

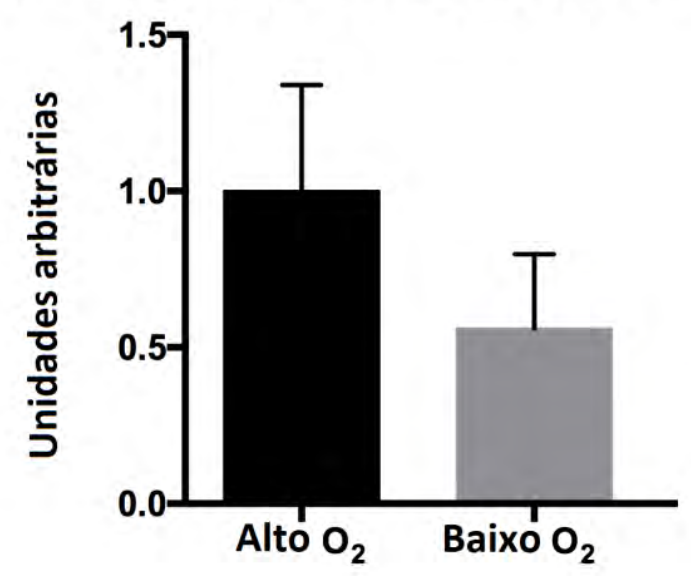

B

Alto $\mathrm{O}_{2}$ Baixo $\mathrm{O}_{2}$

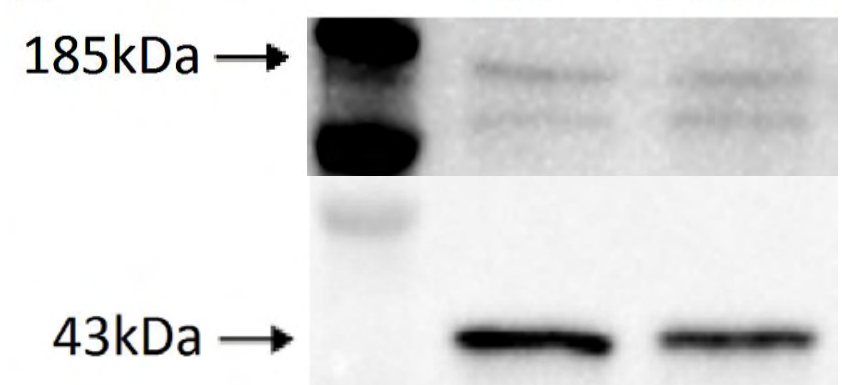

Figura 12. Análises da proteína ERBB2. (A) Expressão relativa e (B) imagem representativa do padrão de bandas encontradas na análise de Western Blotting para a proteína ERBB2 (185 kDa) em blastocistos bovinos cultivados em alta ou em baixa tensão de oxigênio. A expressão da proteína ERBB2 foi normalizada pela expressão da proteína beta-actina (43 kDa). As barras representam as médias e as barras de erros representam o erro padrão da média. Letras diferentes $(a, b)$ acima das barras indicam diferença significativa $(p \leq 0,05)$.

A análise complementar de imunocitoquímica demonstrou, como esperado, que ambas as proteínas ERBB2 e ERBB3 são receptores de membrana localizados apenas no trofoblasto dos blastócitos bovinos, uma vez que não foi observada presença de fluorescência na região da massa celular interna conforme destacado na Figura 13. 

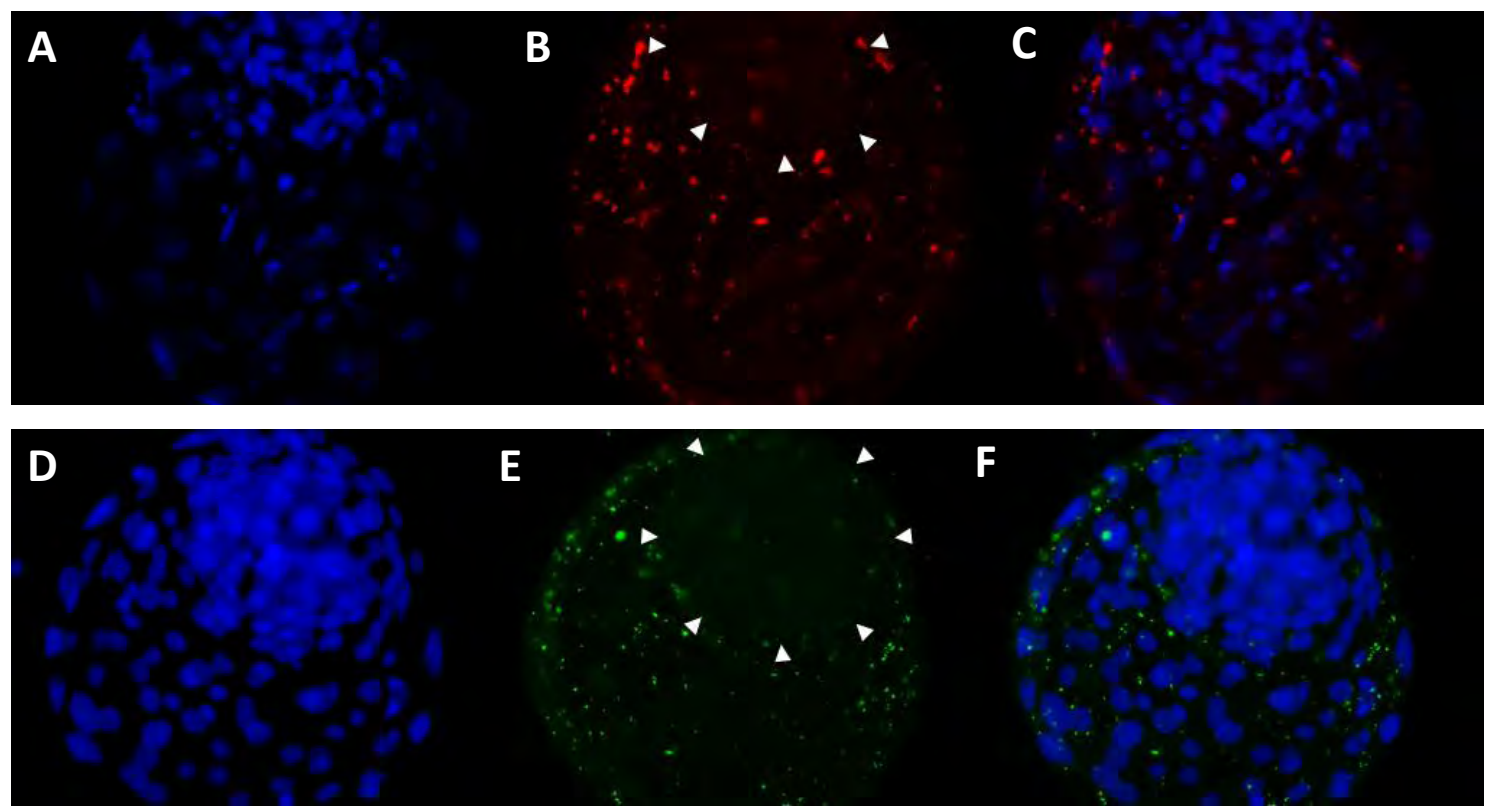

Figura 13. Imunolocalização das proteínas $\operatorname{ERBB2}(A, B$ e C) e ERBB3 (D, E e F) em blastocistos bovinos. As fotomicrografias de confocal representam a marcação do DNA (A e D), a localização dos receptores ERBB2 (B) e ERBB3 (E) e a combinação das duas imagens (C e F). Ambos os receptores estão predominantemente localizados no trofoblasto, o que pode ser confirmado pela ausência de marcação da massa celular interna, na qual não há células do trofoblasblasto, conforme indicado pelas cabeças de seta nas fotomicrografia B e E (40x).

\subsubsection{Suplementação do meio de cultivo com antioxidantes}

As taxas de clivagem e blastocisto foram avaliadas em 10 rotinas independentes. Não houve diferença significativa entre os cultivos controle, produzido apenas em alta tensão de oxigênio ou na alta tensão com suplementação com cisteína e cisteamina (Tabela 2).

Tabela 2. Médias e desvio padrão (DP) das taxas de clivagem e blastocistos de embriões bovinos produzidos em alta tensão de oxigênio (20\%) na ausência e na presença da suplementação com antioxidantes cisteína e cisteamina $(C+C)$.

\begin{tabular}{lcccccc}
\hline & No & Nc & $\begin{array}{c}\text { Taxa de } \\
\text { Clivagem } \\
\text { (média } \pm \text { DP) }\end{array}$ & Nb & $\begin{array}{c}\text { Taxa de } \\
\text { Blastocistos } \\
\text { (média } \pm \text { DP) }\end{array}$ & Taxa Total \\
\hline Alto $\mathbf{O}_{2}$ & 927 & 786 & $84,39 \% \pm 3,66$ & 206 & $23,97 \% \pm 11,41$ & $22,23 \%$ \\
Alto $\mathbf{O}_{2} \mathbf{C}+\mathrm{C}$ & 914 & 766 & $83,01 \% \pm 6,23$ & 235 & $25,76 \% \pm 7,99$ & $25,71 \%$ \\
\hline TOTAL & 1.841 & 1.552 & - & 441 & - & - \\
\hline
\end{tabular}

No= número de oócitos

$\mathrm{Nc}=$ número de embriões clivados

$\mathrm{Nb}=$ Número de blastocistos

$\mathrm{C}+\mathrm{C}=$ cisteína + cisteamina 
Os níveis intracelulares de espécies reativas de oxigênio (EROs) foram determinados em 22 e 32 blastocistos cultivados em alta tensão de oxigênio na ausência e presença de cisteína e cisteamina, respectivamente (Figura 14). Os resultados foram analisados em unidades arbitrárias de fluorescência. $\mathrm{O}$ grupo cultivado em alta tensão sem o tratamento $(6,452 \pm 0,833)$ apresentou níveis maiores de EROs em relação ao grupo alta tensão suplementado com $C+C(3,492 \pm 0,336$, considerando $p \leq 0,05)$.
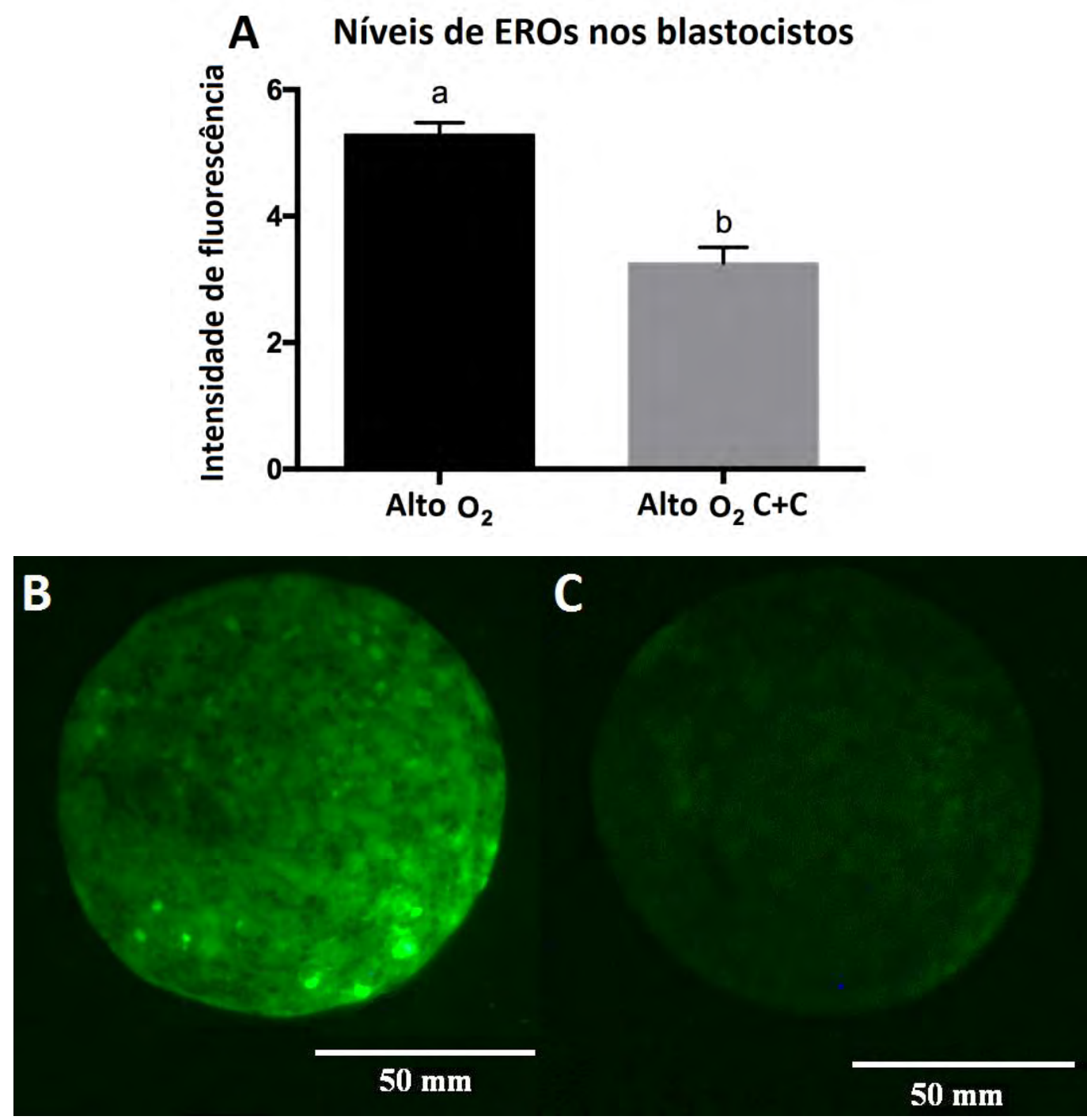

Figura 14. Níveis intracelulares de EROs (em unidades arbitrárias de fluorescência) em blastocistos bovinos produzidos em alta tensão de oxigênio na ausência e presença de tratamento com antioxidantes (A). As barras do gráfico representam as médias e as barras de erros representam o erro padrão da média. Letras diferentes ( $a, b)$ acima das barras indicam diferença significativa $(p \leq 0,05)$. Fotomicrografias de epifluorescência de 
blastocistos produzidos em alta tensão de oxigênio na ausência de tratamento (B) e na presença de suplementação com cisteína e cisteamina (C) e corados com CellROX Green $(40 x)$.

No intuito de avaliar se o tratamento com antioxidantes é capaz de prevenir as alterações induzidas pelo estresse oxidativo, este estudo avaliou a expressão das isoformas do miR-199a, seus possíveis transcritos alvo ERBB2 e ERBB3 e proteína ERBB2. Entre as isoformas do miR199a, o miR-199a-3p não apresentou diferença significativa entre os grupos de blastocisto cultivados em alta tensão na ausência $(0,0000125 \pm 0,0000065)$ e presença de antioxidantes $(0,0000175 \pm 0,0000108$, considerando $p \leq 0,05)$, de forma semelhante como observado nas comparações dos cultivos em alta e baixa tensão de oxigênio. O miR-199a-5p também não apresentou diferença significativa entre os embriões cultivados na ausência $(0,0000254 \pm 0,00000489)$ e presença de suplementação com antioxidantes $(0,0000105 \pm 0,000013$, considerando $p \leq 0,05)$ (Figura 15).
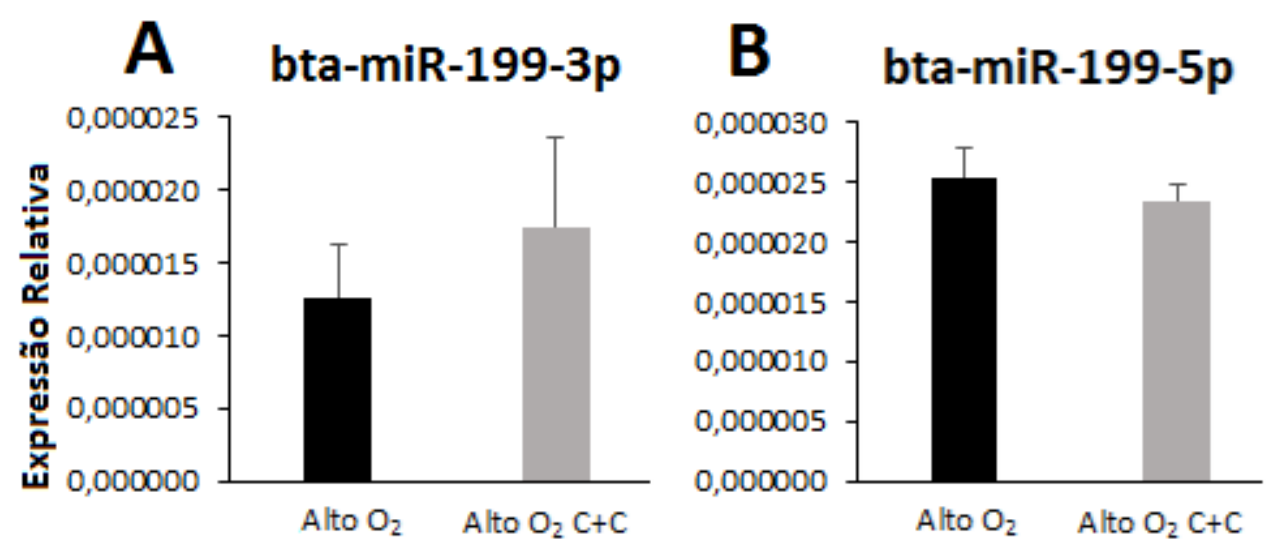

Figura 15. Expressão relativa das isoformas do miR-199a. Os gráficos $A$ e $B$ apresentam a comparação da expressão relativa das isoformas do miR-199a entre os grupos de blastocistos cultivados em alta tensão de oxigênio na ausência e presença de suplementação do meio de cultivo com antioxidantes (cisteína e cisteamina). As barras representam as médias e as barras de erros representam o erro padrão da média.

Os resultados de expressão dos RNAm ERBB2 $(0,03 \pm 0,002$ e 0,03 $\pm 0,004$ grupo de alto

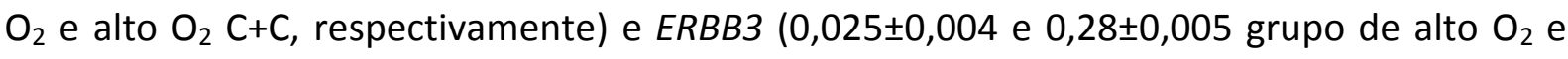
alto $\mathrm{O}_{2} \mathrm{C}+\mathrm{C}$, respectivamente, considerando $\left.\mathrm{p} \leq 0,05\right)$ não demonstraram diferença significativa entre os grupos cultivados em alta tensão sem suplementação e suplementados com $C+C$, de forma semelhante ao observado nos grupos cultivados em alta e baixa tensão 
de oxigênio. Os resultados da proteína ERBB2 também não difere entre os grupos de embriões cultivados em alta tensão de oxigênio na ausência e presença da suplementação $C+C(0,336 \pm 0,283$, considerando $p \leq 0,05)$ (Figura 16).

\section{Níveis de ERBB2 nos blastocistos}

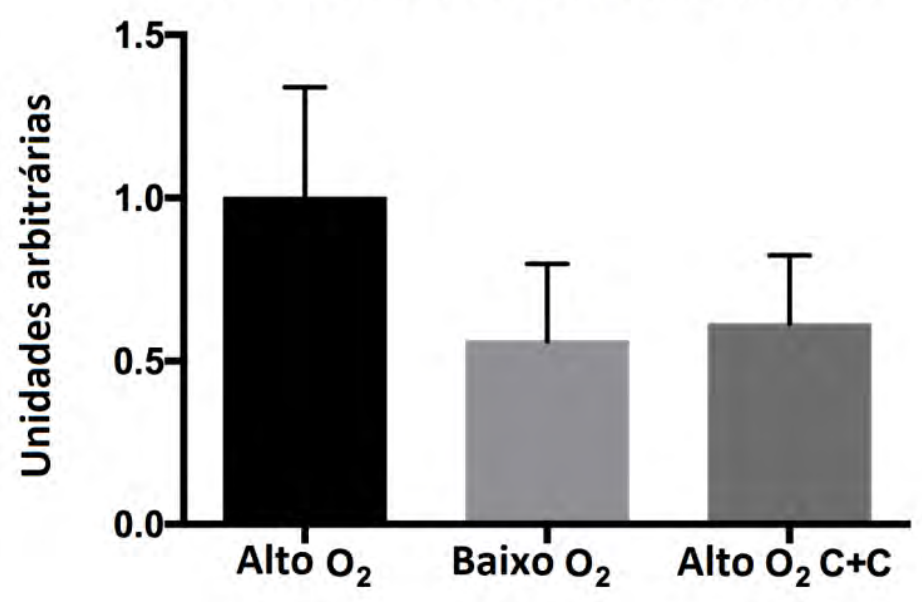

Figura 16. O resultado do Western Blotting, em unidades arbitrárias, demonstrou que a proteína ERBB2 não apresenta diferença de expressão entre os grupos de embriões cultivados em alta tensão na ausência ou presença de antioxidantes ou na baixa tensão de oxigênio. As barras representam as médias e as barras de erros representam o erro padrão da média. Letras diferentes $(a, b)$ acima das barras indicam diferença significativa $(p \leq 0,05)$.

\subsection{Experimento II}

\subsubsection{Perfil de metilação global dos blastocistos}

A imunocitoquímica para avaliação do padrão da metilação global foi realizada para 12 e 9 blastocistos cultivados em alta e baixa tensão de oxigênio, respectivamente. Os resultados da metilação global demonstram que o cultivo embrionário em alta tensão de oxigênio resulta em aumento nos níveis de imunomarcação para 5-mC em relação à baixa tensão de oxigênio (Figura 17). 


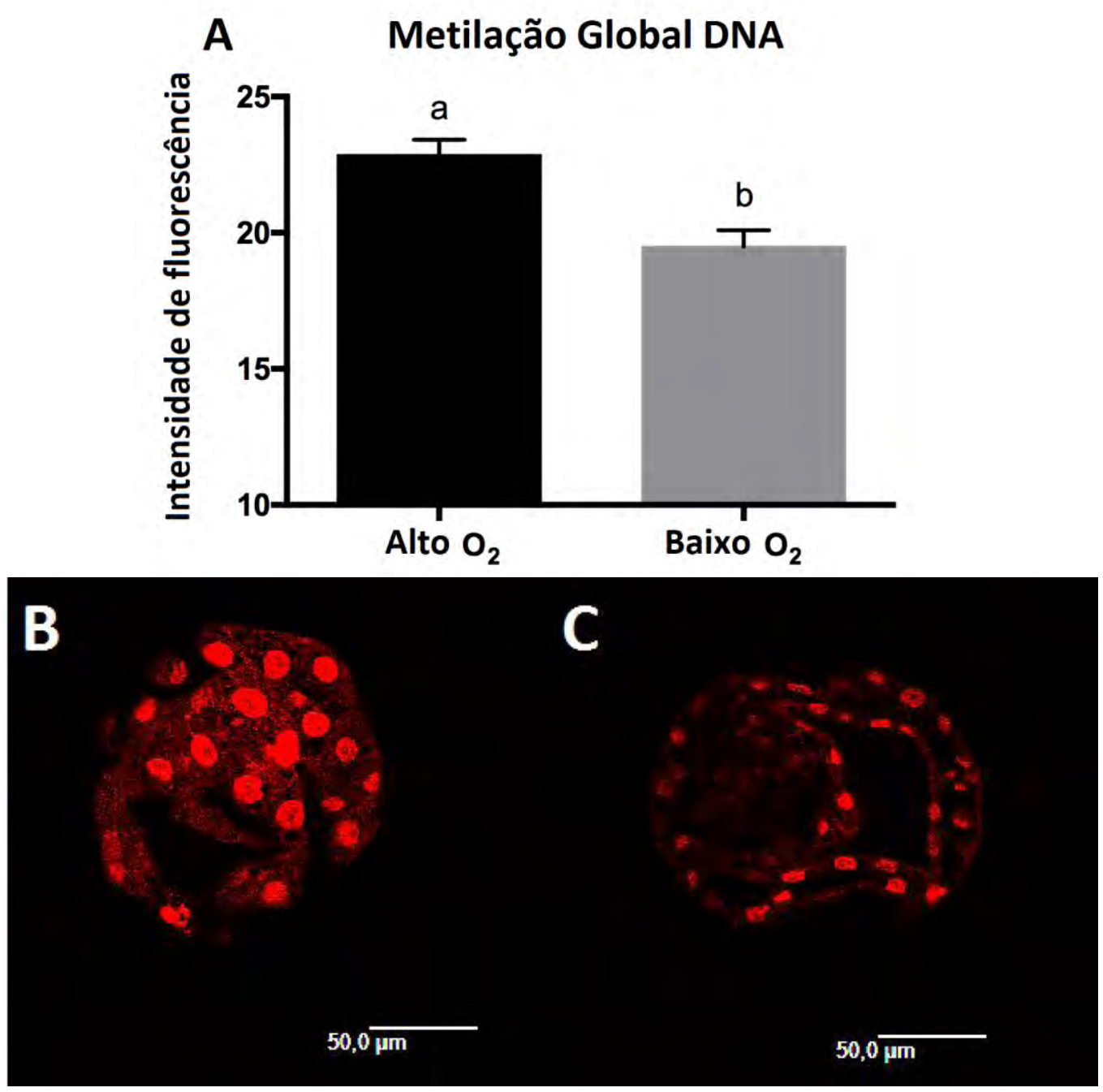

Figura 17. Os níveis de metilação global do DNA (em unidades arbitrárias de fluorescência) em blastocistos bovinos produzidos em alta ou baixa tensão de oxigênio (A). As barras representam as médias e as barras de erros representam o erro padrão da média. Letras diferentes $(a, b)$ acima das barras indicam diferença significativa $(p \leq 0,05)$. Fotomicrografias de confocal de blastocistos produzidos em alta (B) e baixa (C) tensões de oxigênio e imunomarcados para 5-mC (40x).

\subsubsection{Níveis de expressão de RNAm nos blastocistos}

Os resultados da análise do perfil de 96 RNAm para 8 repetições biológicas demonstraram que 40 transcritos foram diferencialmente expressos $(p \leq 0,05)$ entre os grupos de blastocistos cultivados em alta e baixa tensão de oxigênio (Tabela S.4). Entre os 40 RNAm, 39 foram mais expressos em alta tensão de oxigênio em relação a baixa. $O$ transcrito PGK1 foi o único encontrado como menor expressão em alta tensão de oxigênio em relação à baixa (Figura 18). As funções biológicas associadas aos transcritos diferentemente 
expressos são de resposta ao estresse oxidativo (SOD1, CAT, TXN, TNFRSF21, PRDX1, PRDX3, NRF2 e KEAP1), resposta ao estresse oxidativo e proliferação (HSP9OAA1, GLRX2, PTGS2 e PPARG), remodelação epigenética (DNMT3A, HDAC2, H2AFZ, H3F3B, MORF4L2, REST e PAF1), proliferação e diferenciação celular (STAT3, EGFR, MAPK1, CDCA8, NANOG, OTX2, TFAM, PRKCD, PA2G4, HSF1 e CCND2), reconhecimento materno-fetal (IFNT2), apoptose (BAX, BID, CASP9 e TNFRSF21) e metabolismo (PGK1, SREBF1, ACSL3, HAND1 e ATP5L).
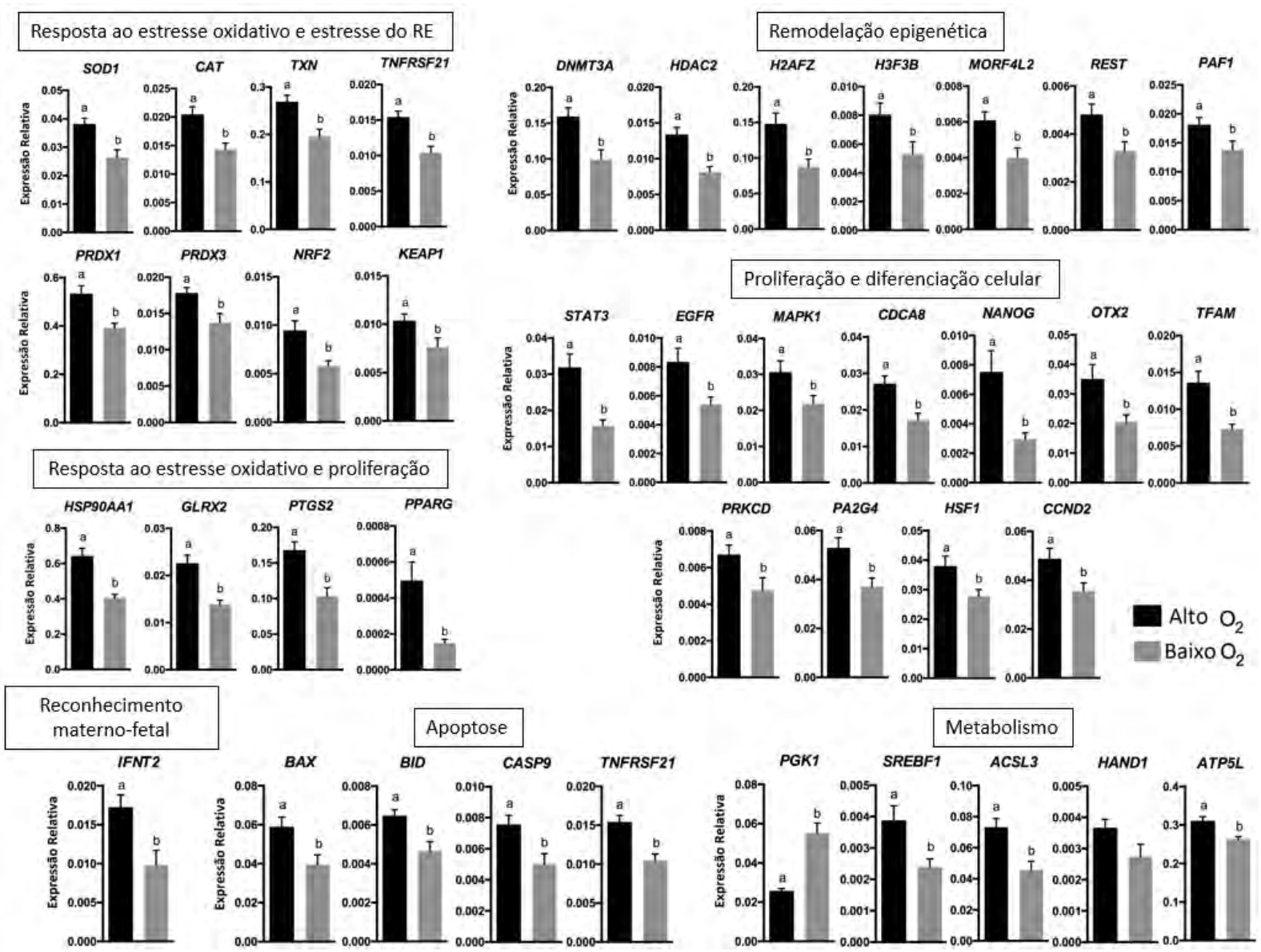

Figura 18. Mapa das funções biológicas e expressão relativa dos 40 transcritos diferentemente expressos entre os cultivos de alta e baixa tensão de oxigênio para blastocistos bovinos produzidos in vitro. As barras do gráfico representam as médias e as barras de erros representam o erro padrão da média. Letras diferentes ( $a, b)$ acima das barras indicam diferença significativa $(p \leq 0,05)$.

\subsubsection{Perfil de microRNAs nos blastocistos}

Os resultados da análise do perfil de 378 miRNAs para três repetições biológicas demonstraram a expressão de 352 miRNAs (Tabela S.3). Os dados foram considerados 
consistentes, uma vez que os pools apresentaram alta repetibilidade quando comparados (Figura 19). Entre os 352 miRNAs expressos, 22 foram identificados como exclusivos de alta tensão, 14 exclusivos de baixa tensão e 316 comuns aos dois sistemas de cultivo (Figura 20).

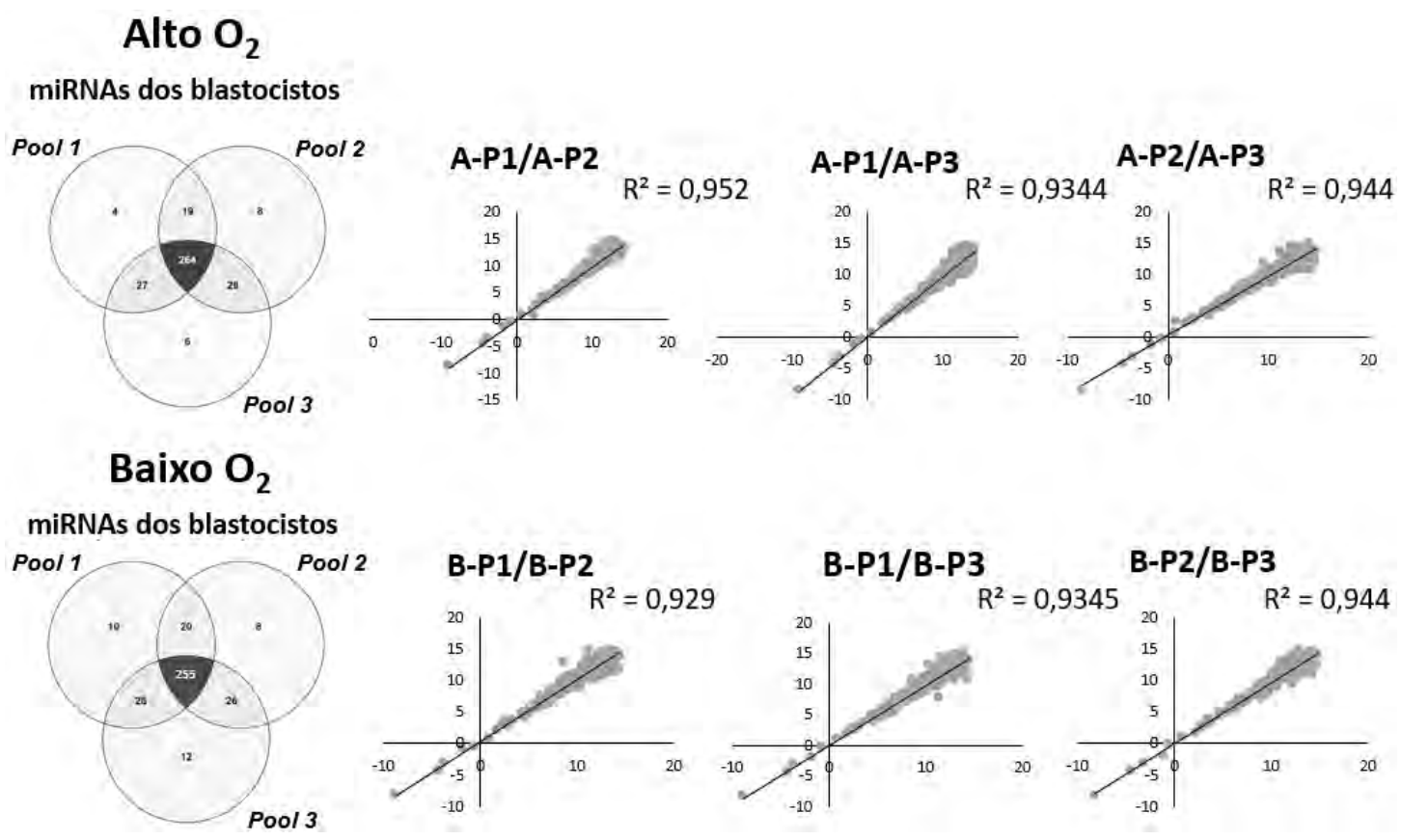

Figura 19. Diagrama de Venn indicando o número de miRNAs expressos em cada um dos pools de 10 blastocistos analisados. Representação gráfica da dispersão do valor de Delta $\mathrm{Ct}$ entre os pools analisados e o valor do coeficiente de determinação da regressão linear $\left(R^{2}\right)$, indicando alta repetibilidade dos resultados de amplificação de miRNAs entre amostras (repetições) do mesmo grupo. A-P1 = alta tensão - pool 1; A-P2 = alta tensão - pool 2; A-P3 = alta tensão - pool 3; B-P1 = baixa tensão - pool 1; B-P2 = baixa tensão - pool 2; B-P3 = baixa tensão - pool 3. 


\section{Perfil de miRNAs nos blastocistos bovinos}

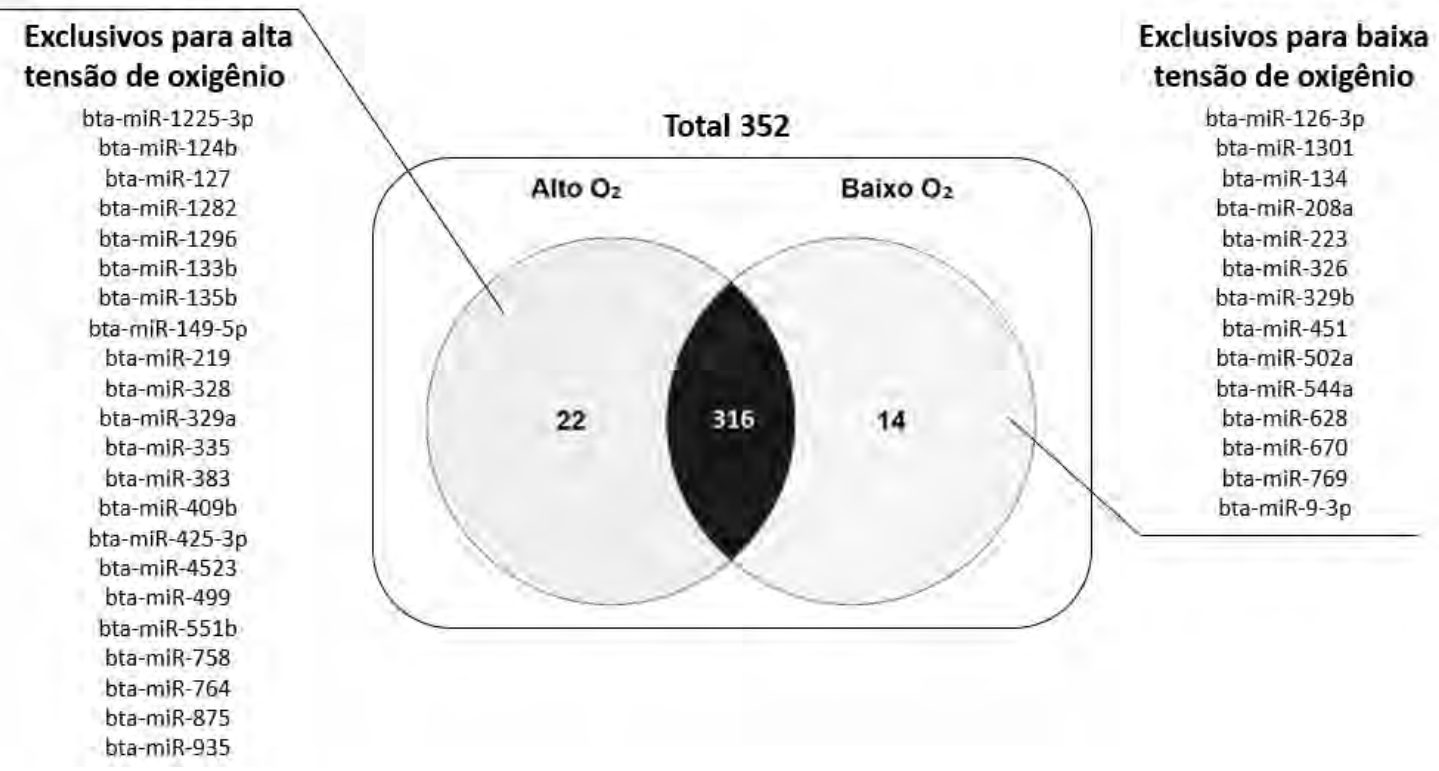

Figura 20. Diagrama de Venn indicando a expressão de 352 miRNA em blastocistos bovinos produzidos in vitro. As caixas de texto apresentam as listas dos miRNAs considerados exclusivos para alta e baixa tensões de oxigênio.

Dentre os 316 miRNAs identificados como comuns aos dois sistemas de cultivo, oito foram considerados diferentemente expressos, sendo cinco aumentados e três diminuídos na alta tensão em relação a baixa tensão de oxigênio (Figura 21). A partir dos miRNAs diferencialmente expressos foram analisadas as principais vias enriquecidas para alta e baixa tensões de oxigênio, sendo consideradas as primeiras 20 vias ranqueadas pelo valor de $p$ transformado por - $\log _{10}$ (Figura 22). O grupo de miRNAs mais abundantes em alta tensão de oxigênio apresentou um maior número de vias relacionadas a câncer em relação a baixa tensão de $\mathrm{O}_{2}$. Vias relacionadas com câncer geralmente estão associadas a funções de divisão celular para proliferação, e diferenciação celular. Em contrapartida, entre as vias relacionadas com os miRNAs menos abundantes em alta tensão destaca-se a via de sinalização ERBB, relacionada com a interação materno-embrionária, foco do presente estudo. 


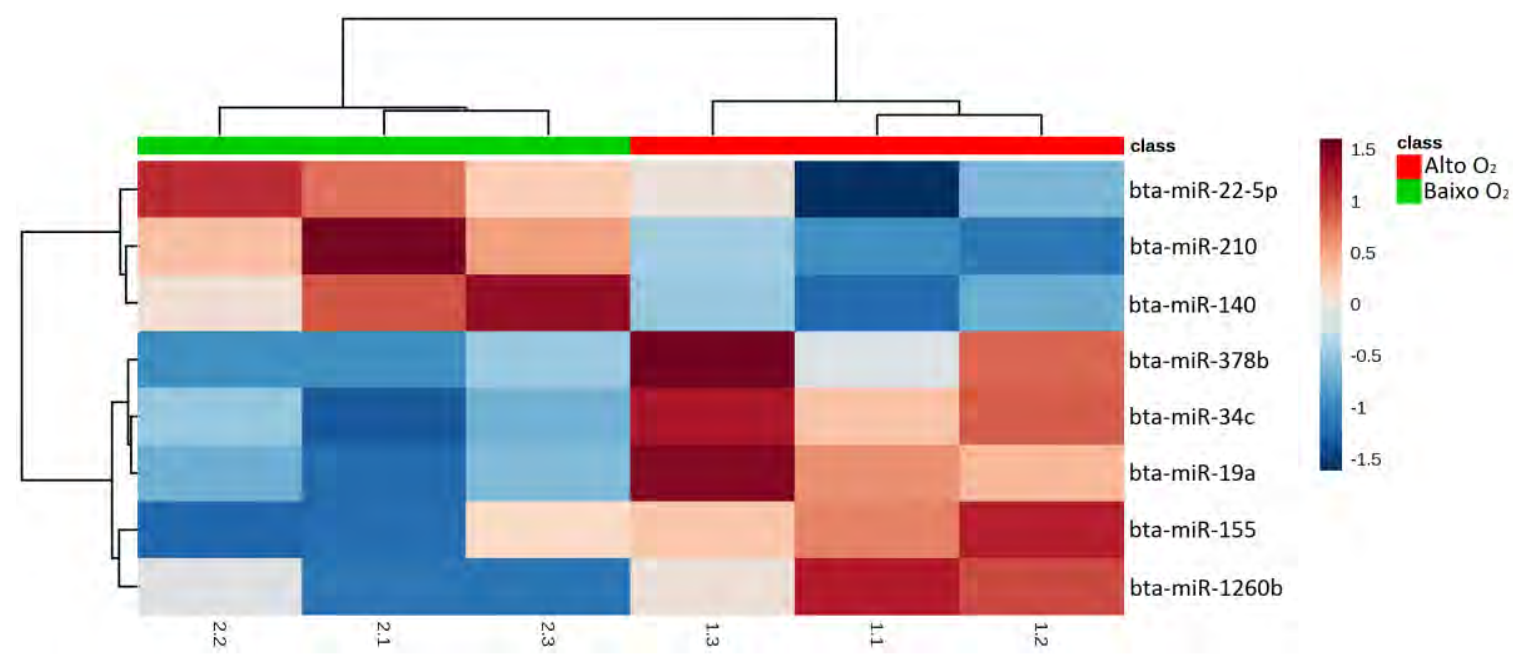

Figura 21. Heatmap indicando a expressão dos 8 miRNAs diferentemente expressos $(p \leq 0,05)$ entre os blastocistos desenvolvidos em alta e baixa tensão de oxigênio, para 3 repetições biológicas.

A Vias enriquecidas pelos miRNAs mais expressos na alta tensão de $\mathrm{O}_{2}$
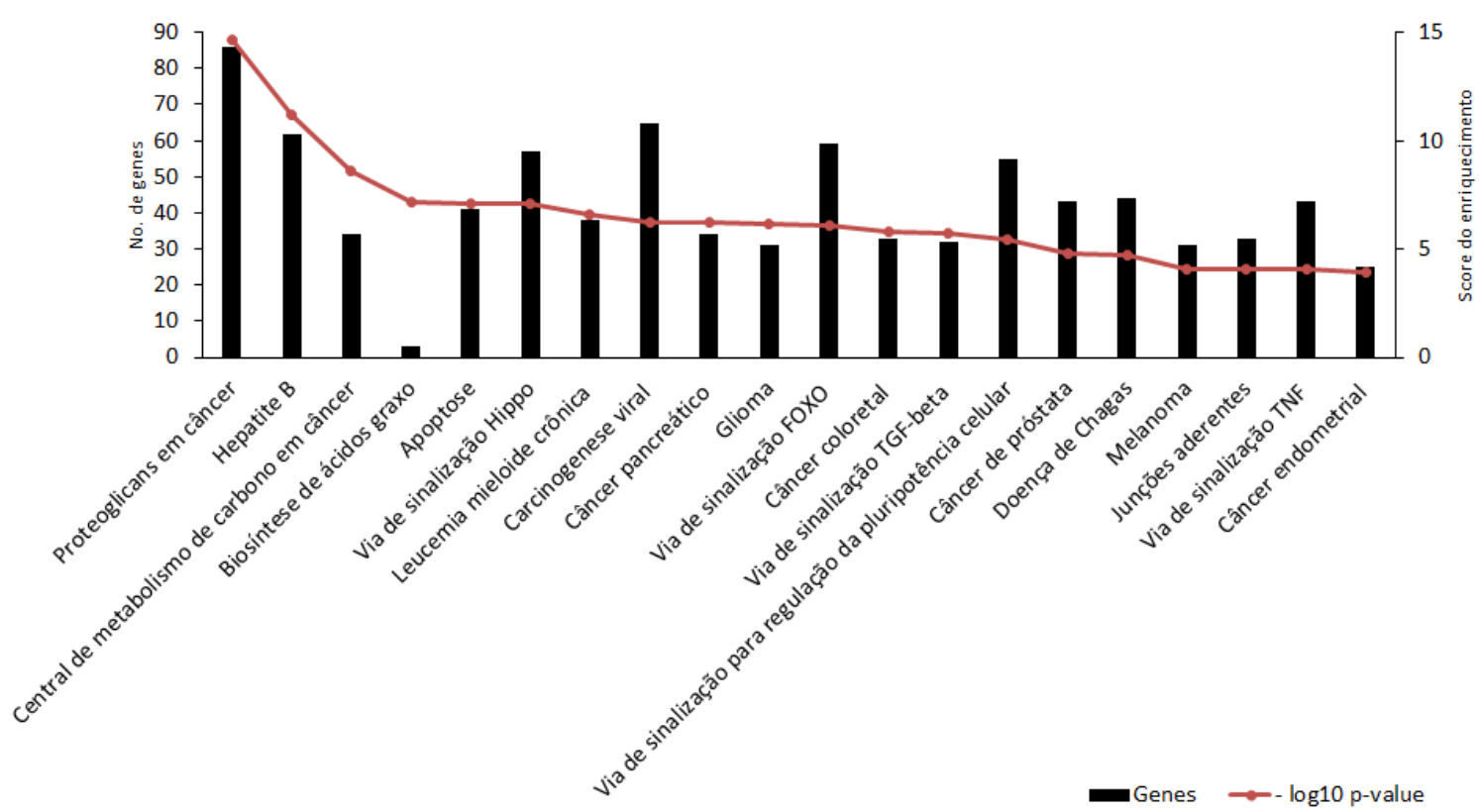


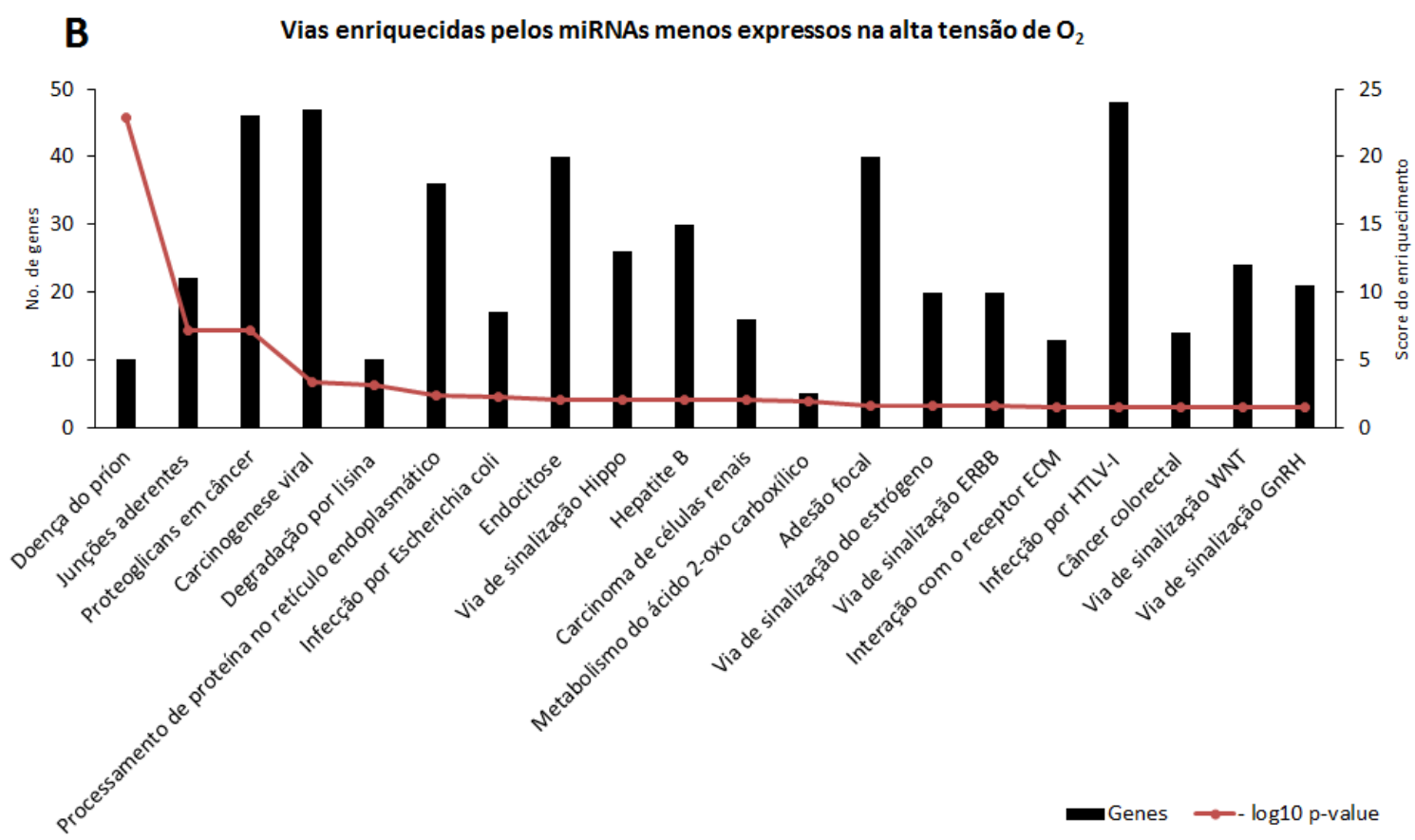

Figura 22. Principais vias enriquecidas pelos miRNAs mais (A) e menos (B) abundantes na alta tensão de oxigênio em relação a baixa tensão de oxigênio. Os valores do eixo $Y$ da esquerda representam o número de genes enriquecidos pelos miRNAs para as respectivas vias, enquanto o eixo $\mathrm{Y}$ da direita representa o valor de enriquecimento do score para cada via. O valor de enriquecimento de score é o $-\log _{10}$ do valor de $p$, que é um valor extraído do algoritmo do software DIANA TOOLS com base na proporção de simulações de alvos para os miRNAs.

\subsubsection{Efeito da suplementação do meio de cultivo com antioxidantes na expressão dos miRNA}

Para confirmar os efeitos do estresse oxidativo na modulação dos níveis de miRNAs, embriões bovinos foram produzidos in vitro em alta tensão de oxigênio na presença e na ausência de suplementação do sistema antioxidante cisteína e cisteamina (grupo alto $\mathrm{O}_{2}$ $C+C$ ). Nestes embriões foram amplificados os oito miRNAs (bta-miR-34c, bta-miR-19a, btamiR-210, bta-miR-140, bta-miR-1260b, bta-miR-378b, bta-miR-22-5p e bta-miR-155) que diferiram entre embriões produzidos na alta e baixa tensão de oxigênio. Para os grupos de embriões cultivados em alta e baixa tensão, 5 miRNAs (bta-miR-378b, bta-miR-34c, bta-miR19a, bta-miR-155, bta-miR-1260b) estavam mais abundantes na alta tensão enquanto 3 miRNAs (bta-miR-22-5p, bta-miR-210 e bta-miR-140) estavam menos abundantes na alta tensão em comparação a baixa tensão de oxigênio. Os 8 miRNAs não apresentaram 
diferença significativa entre os grupos de embriões cultivados em alta tensão na ausência e na presença da suplementação C+C (Tabela S.5) (Figura 23).
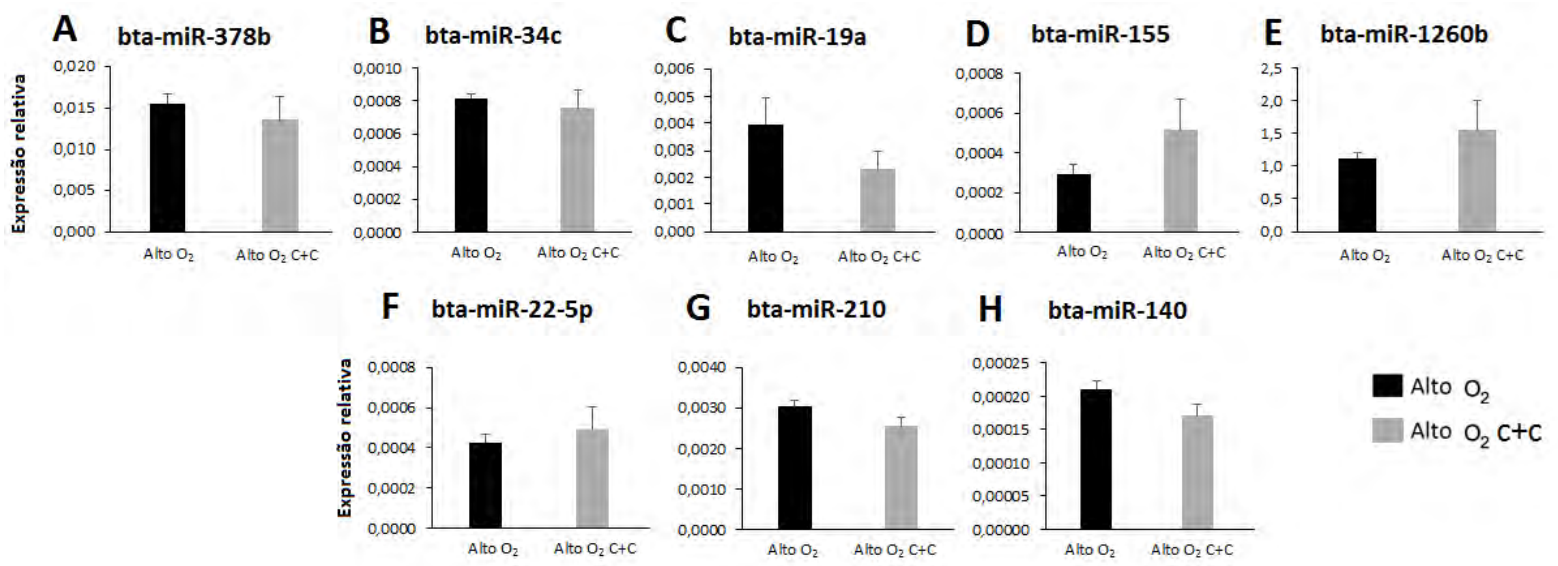

$$
\begin{aligned}
& \text { Alto } \mathrm{O}_{2} \\
& \text { Alto } \mathrm{O}_{2} \mathrm{C}+\mathrm{C}
\end{aligned}
$$

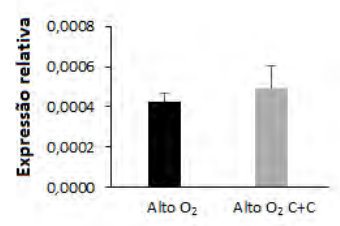

Aito $\mathrm{O}_{2} \quad$ Aito $\mathrm{O}_{2} \mathrm{C}+\mathrm{C}$

Figura 23. Expressão relativa dos miRNAs. Os gráficos $A, B, C, D E, F, G$ e $H$ a expressão relativa dos mesmos miRNAs entre os grupos de blastocistos cultivados em alta tensão de oxigênio na ausência e presença de suplementação do meio de cultivo com antioxidantes (cisteína e cisteamina). As barras representam as médias e as barras de erros representam o erro padrão da média. Letras diferentes $(a, b)$ acima das barras indicam diferença significativa $(p \leq 0,05)$.

\subsection{Experimento III}

\subsubsection{Padrão de secreção dos exossomos presentes no meio de cultivo in vitro de embriões bovinos nos dias 3 e 7}

Os exossomos isolados do meio de cultivo da produção in vitro de embriões bovinos sofreram alterações no padrão de secreção dependentes da condição de tensão de oxigênio durante o desenvolvimento. Os tamanhos dos exossomos não diferiram no meio de cultivo no dia $3(117,8 \pm 28,66$ e 124,6 2 32,1 para alta e baixa tensão, respectivamente), e nem no dia $7(112,24 \pm 18,52$ e 107,15 $\pm 19,01$ para alta e baixa tensão, respectivamente) de oxigênio (Figura 24). 


\section{Tamanho dos exossomos}

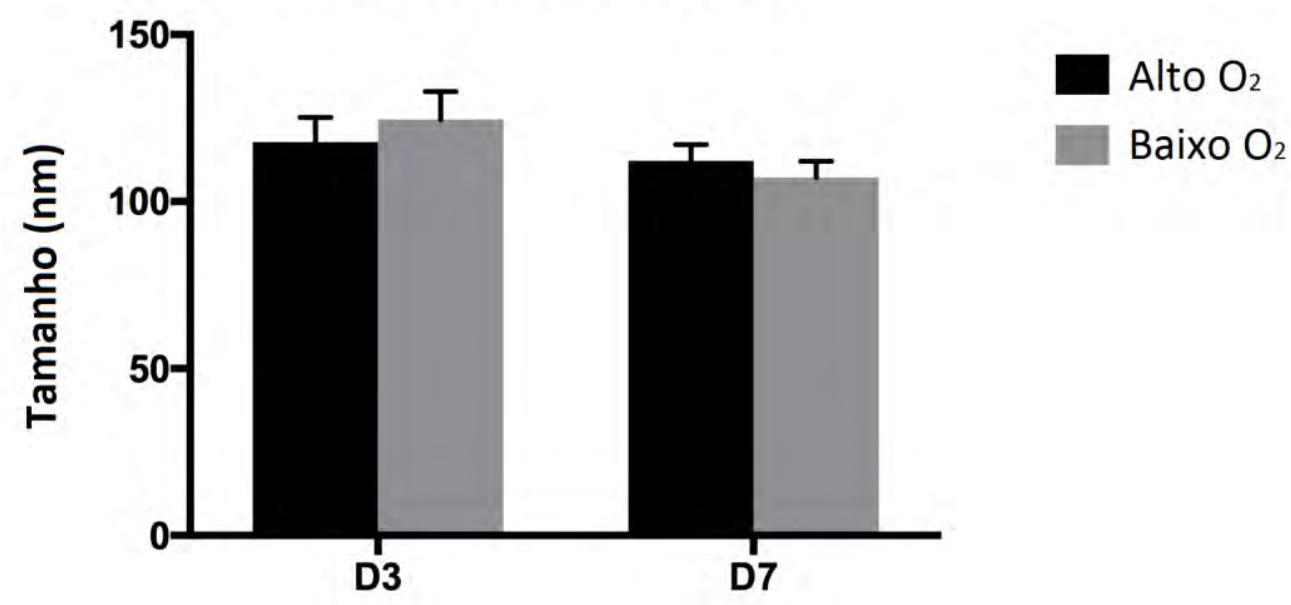

Figura 24. Média das modas e desvio padrão dos tamanhos dos exossomos $(\mathrm{nm})$ observados no meio de cultivo durante os dias 3 e 7 do desenvolvimento de embriões bovinos produzidos in vitro em condições de alta e baixa tensão de oxigênio para 3 repetições biológicas. As barras representam as médias e as barras de erros representam o erro padrão da média. Letras diferentes $(a, b)$ acima das barras indicam diferença significativa $(p \leq 0,05)$.

A concentração dos exossomos foi significativamente diferente entre os grupos de alta e baixa tensão de oxigênio em ambos os dias do desenvolvimento, D3 e D7. O meio de cultivo em D3 apresentou menor concentração de partículas/ml em alta tensão $(178.000 .000,00 \pm 28.317 .082,17)$ em relação a baixa tensão de $\mathrm{O}_{2}$ $(283.9333 .333,33 \pm 72.160 .997,24)$. Contudo, em D7 a concentração de partículas foi maior na alta tensão $(393.133 .333,33 \pm 140.869 .172,67)$ em comparação com a baixa tensão de $\mathrm{O}_{2}$ $(252.466 .666,67 \pm 117.841 .822,95)$ (Figura 25). 


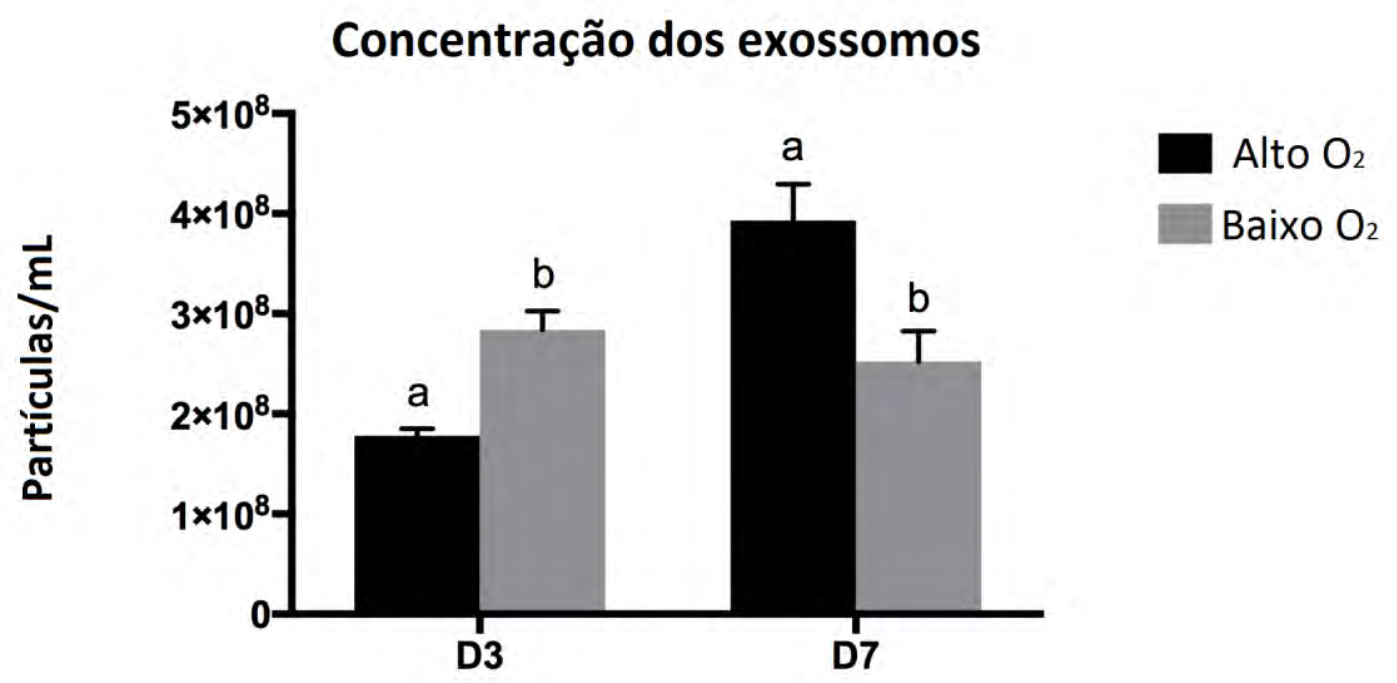

Figura 25. Média e desvio padrão das concentrações de exossomos (partículas $/ \mathrm{mL}$ ) observada no meio de cultivo durante os dias 3 e 7 do desenvolvimento de embriões bovinos produzidos in vitro em condições de alta e baixa tensão de oxigênio para 3 repetições biológicas. As barras representam as médias e as barras de erros representam o erro padrão da média. Letras diferentes $(a, b)$ acima das barras indicam diferença significativa $(p \leq 0,05)$.

\subsubsection{Perfil de microRNAs dos exossomos presentes no meio de cultivo de embriões bovinos nos dias 3}

Os resultados da análise do perfil de 378 miRNAs para três repetições biológicas detectou a presença de 281 miRNAs em exossomos isolados do meio de cultivo em D3 (Tabela S.6). Os dados foram considerados consistentes, uma vez que os pools apresentaram alta repetibilidade quando comparados (Figura 26). Entre os 281 miRNAs identificados, 10 foram considerados exclusivos de alta tensão, 19 exclusivos de baixa tensão e 252 comuns aos dois sistemas de cultivo (Figura 27). 


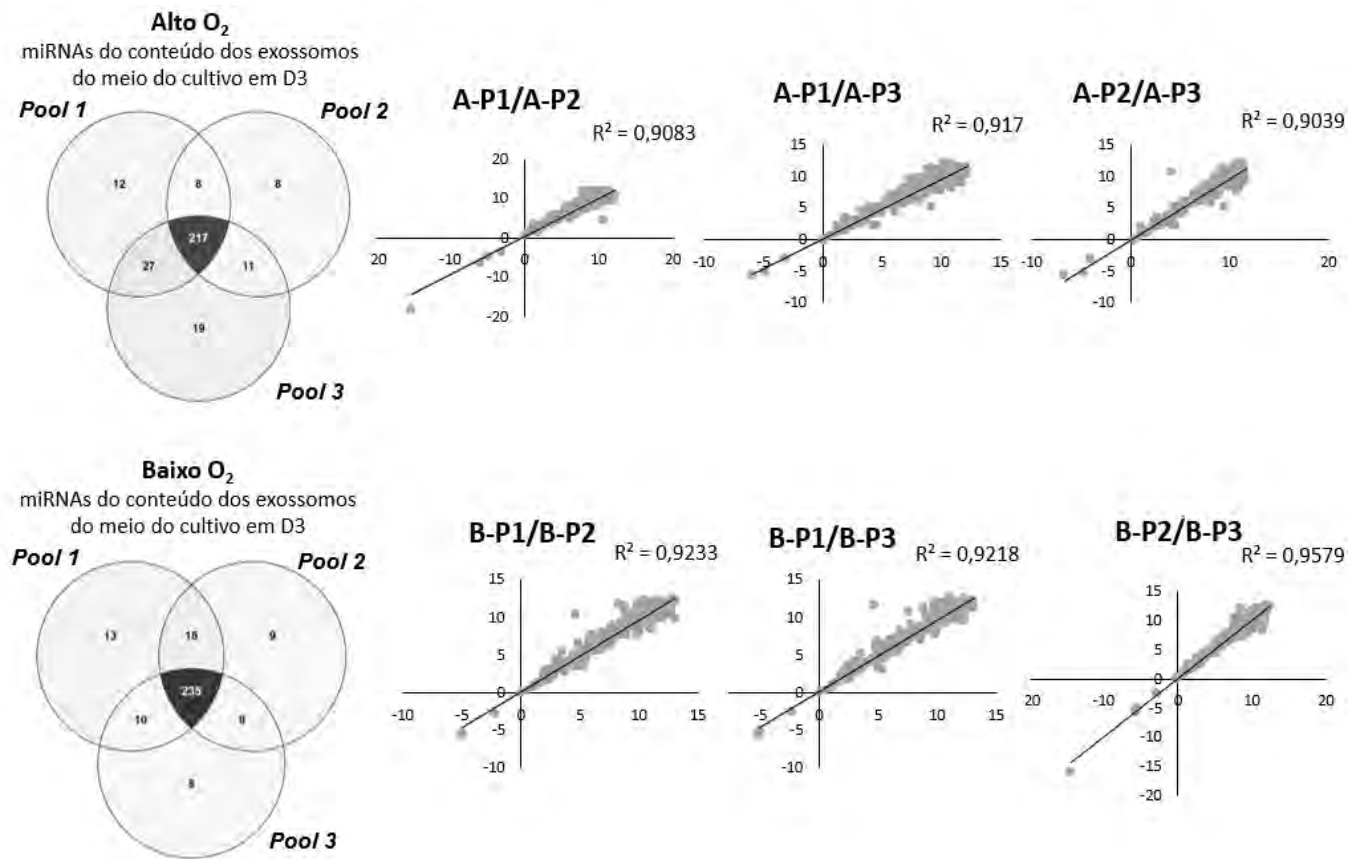

Figura 26. Diagrama de Venn indicando o número de miRNAs expressos em cada um dos pools de meio de cultivo retiradas junto com o feeding no dia 3 do cultivo. As análises foram realizadas para 3 repetições biológicas. Cada repetição biológica consistiu em um pool de meio de cultivo de 3 rotinas. Representação gráfica da dispersão do valor de Delta Ct entre os pools analisados e o valor do coeficiente de determinação da regressão linear $\left(R^{2}\right)$, indicando alta repetibilidade dos resultados de amplificação de miRNAs entre amostras (repetições) do mesmo grupo. A-P1 = alta tensão - pool $1 ; A-P 2=$ alta tensão - pool $2 ; A-P 3=$ alta tensão - pool 3; B-P1 = baixa tensão - pool 1; B-P2 = baixa tensão - pool 2; B-P3 = baixa tensão - pool 3.

\section{Perfil de miRNAs do conteúdo dos exossomos do meio do cultivo de embriões em D3}

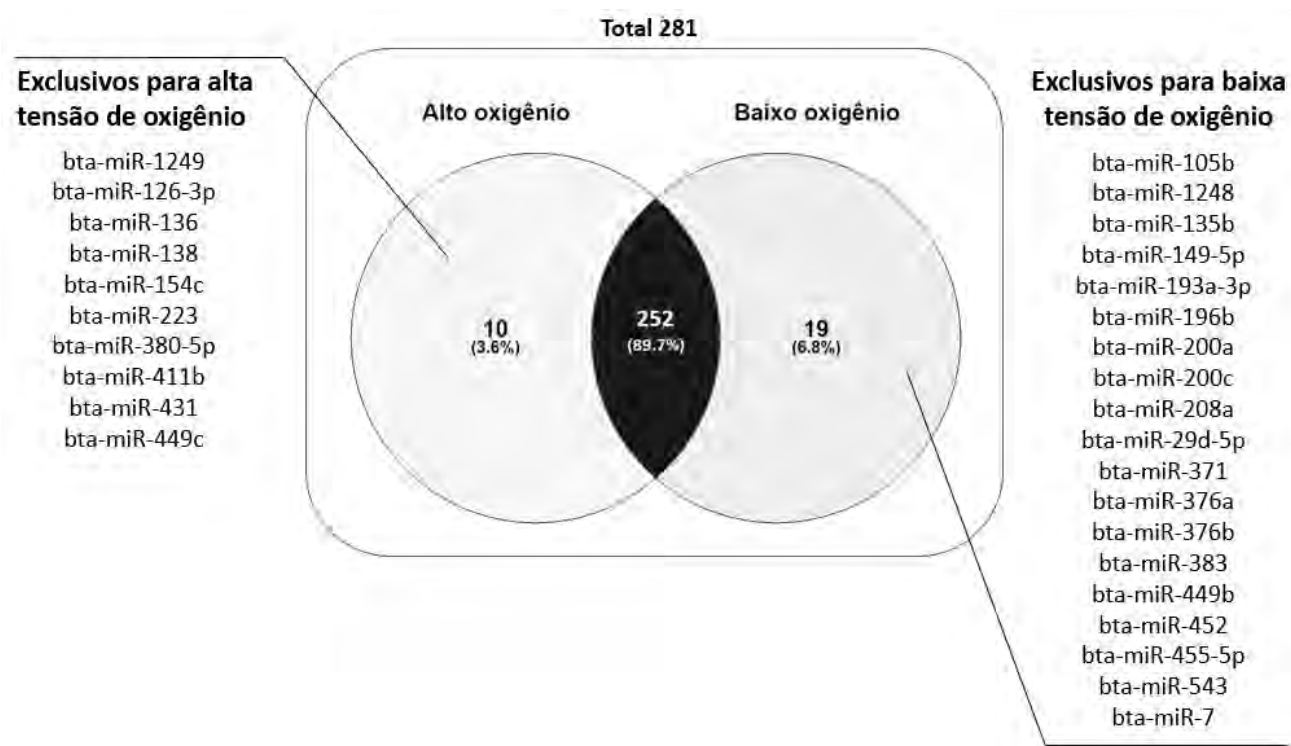

Figura 27. Diagrama de Venn indicando a presença de 281 miRNA no conteúdo dos exossomos isolados do meio do cultivo de embriões bovinos produzidos in vitro no dia 3 do desenvolvimento. As caixas de texto apresentam as listas dos miRNAs considerados exclusivos para alta e baixa tensões de oxigênio. 
Entre os 281 miRNAs identificados no conteúdo dos exossomos como comuns aos dois sistemas de cultivo, 15 foram considerados diferentemente expressos, sendo quatro elevados e 11 diminuídos na alta tensão em relação a baixa tensão de oxigênio (Figura 28). A partir dos miRNAs diferencialmente expressos foram analisadas as principais vias enriquecidas para alta e baixa tensões de oxigênio, sendo consideradas as primeiras 20 vias ranqueadas pelo valor de $\mathrm{p}$ transformado por $-\log _{10}$ (Figura 29). Ambos os grupos, Alto e Baixo $\mathrm{O}_{2}$, apresentaram uma grande quantidade de vias relacionadas com câncer.

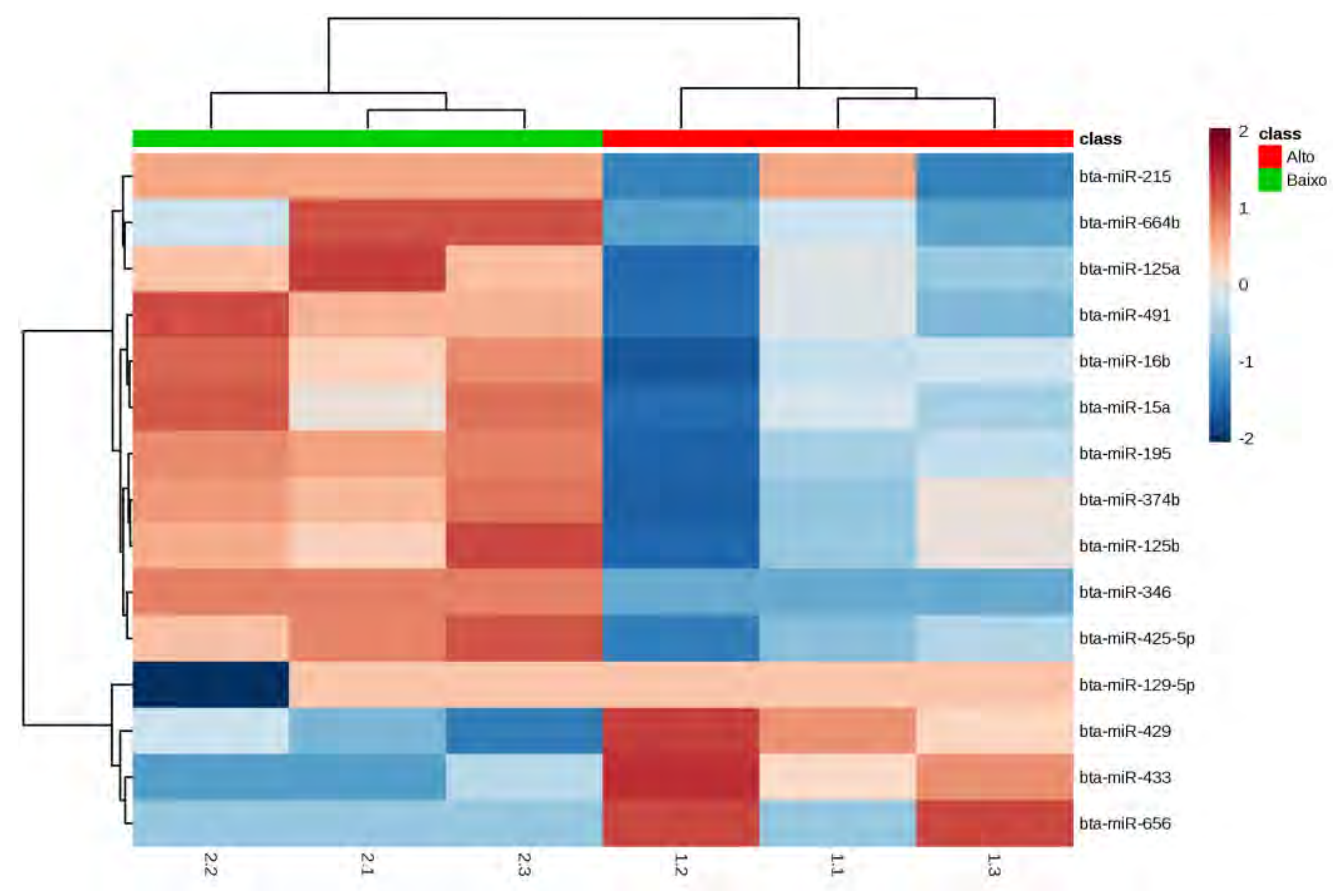

Figura 28. Heatmap indicando 15 miRNAs diferentemente expressos $(p \leq 0,05)$ no conteúdo de exossomos isolados do meio de cultivo de produção in vitro de embriões desenvolvidos em alta ou baixa tensão de oxigênio no dia 3 do cultivo, para 3 repetições biológicas. 

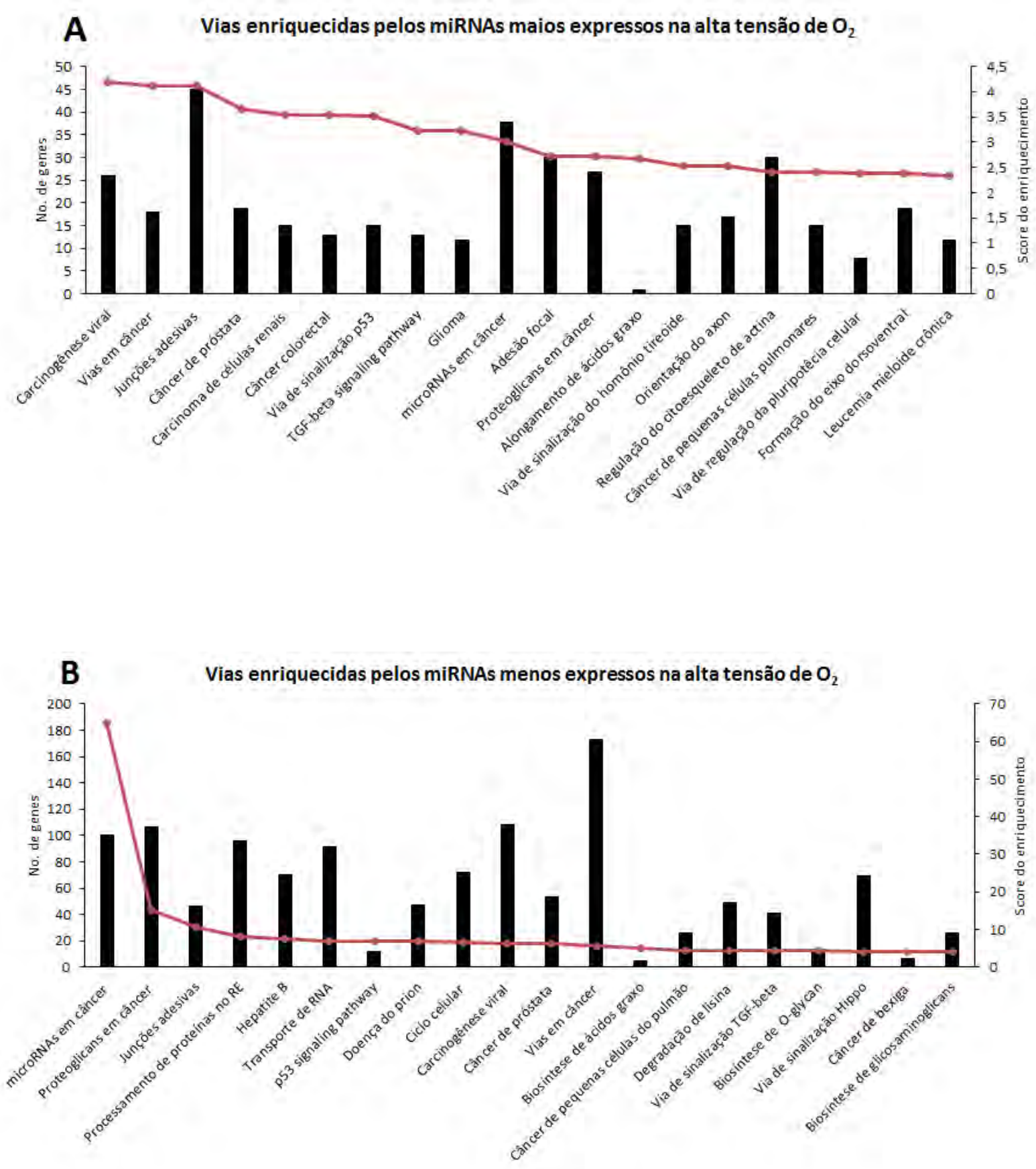

Figura 29. Principais vias enriquecidas pelos miRNAs mais (A) e menos (B) expressos na alta tensão de oxigênio em relação a baixa tensão de oxigênio para exossomos isolados do meio de cultivo no dia 3 em três repetições biológicas. Os valores do eixo $Y$ da esquerda representam o número de genes enriquecidos pelos miRNAs para as respectivas vias, enquanto o eixo $\mathrm{Y}$ da direita representa o valor de enriquecimento do score para cada via. $O$ valor de enriquecimento de score é o $-\log _{10}$ do valor de $p$, que é um valor extraído do algoritmo do software DIANA TOOLS com base na proporção de simulações de alvos para os miRNAs. 


\subsubsection{Perfil de microRnAs dos exossomos presentes no meio de cultivo de embriões bovinos nos dias 7}

Os resultados da análise do perfil de 378 miRNAs para três repetições biológicas demonstraram a expressão de 325 miRNAs no conteúdo de exossomos isolados do meio de cultivo em D3 (Tabela S.6). Os dados foram considerados consistentes, uma vez que os pools apresentaram alta repetibilidade quando comparados (Figura 30). Entre os 325 miRNAs identificados, 25 foram considerados exclusivos de alta tensão, 14 exclusivos de baixa tensão e 286 comuns aos dois sistemas de cultivo (Figura 31).

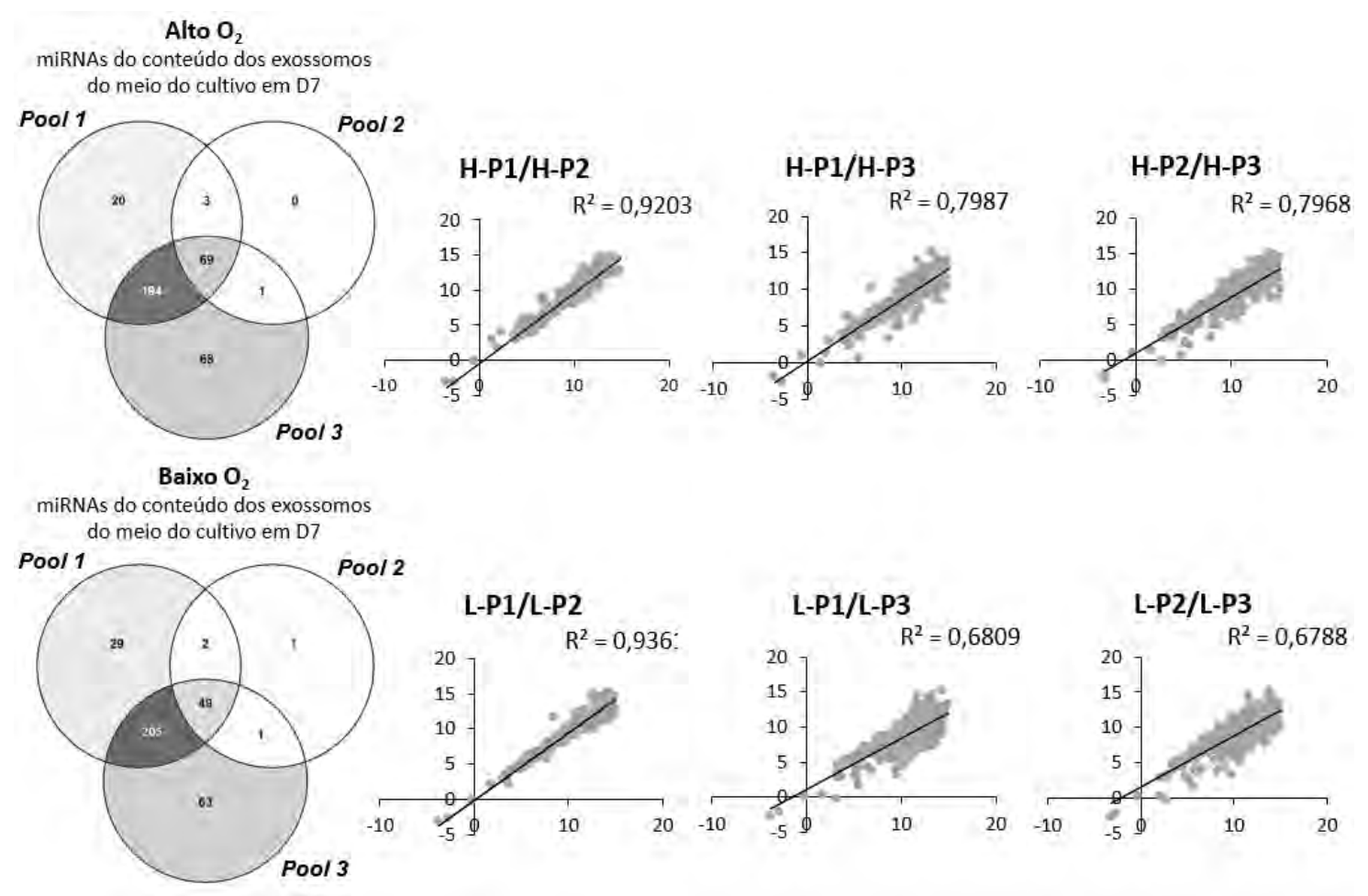

Figura 30. Diagrama de Venn indicando o número de miRNAs expressos em cada um dos pools de meio de cultivo retiradas no dia 7 do cultivo. As análises foram realizadas para três repetições biológicas. Cada repetição biológica consistiu em um pool de meio de cultivo de três rotinas. Representação gráfica da dispersão do valor de Delta Ct entre os pools analisados e o valor do coeficiente de determinação da regressão linear $\left(R^{2}\right)$, indicando alta repetibilidade dos resultados de amplificação de miRNAs entre amostras (repetições) do mesmo grupo. A-P1 = alta tensão - pool $1 ; \mathrm{A}-\mathrm{P} 2$ = alta tensão - pool $2 ; \mathrm{A}-\mathrm{P} 3$ = alta tensão pool 3; B-P1 = baixa tensão - pool 1; B-P2 = baixa tensão - pool 2; B-P3 = baixa tensão - pool 3. 


\section{Perfil de miRNAs do conteúdo dos exossomos do meio do cultivo de embriões em D7}

Total 325

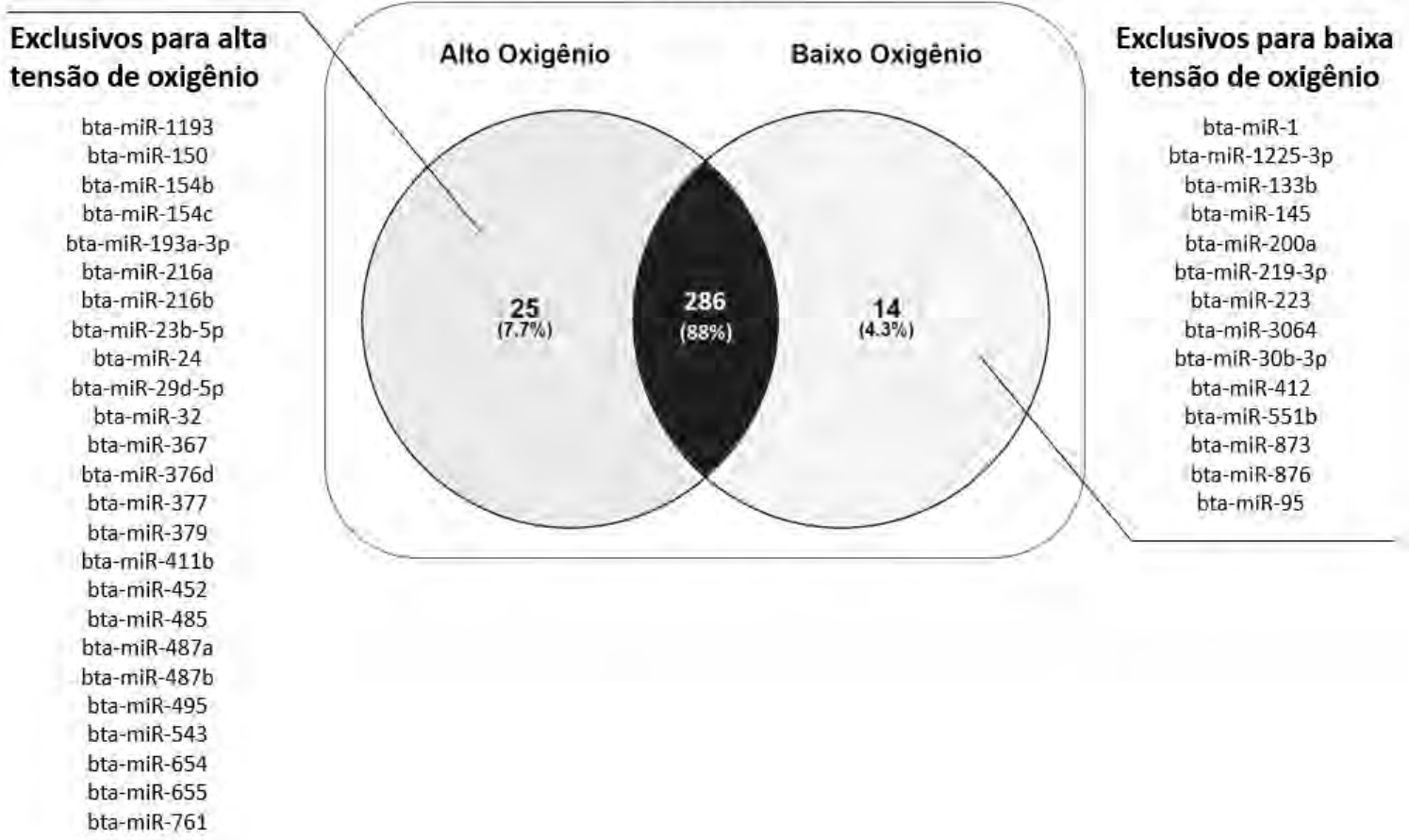

Figura 31. Diagrama de Venn indicando a presença de 325 miRNA no conteúdo dos exossomos isolados do meio do cultivo de embriões bovinos produzidos in vitro no dia 7 do desenvolvimento. As caixas de texto apresentam as listas dos miRNAs considerados exclusivos para alta e baixa tensões de oxigênio.

Entre os 325 miRNAs identificados no conteúdo dos exossomos como comuns aos dois sistemas de cultivo, 18 foram considerados diferentemente expressos, sendo 16 elevados e dois diminuídos na alta tensão em relação a baixa tensão de oxigênio (Figura 32). A partir dos miRNAs diferencialmente detectados foram analisadas as principais vias enriquecidas para alta e baixa tensões de oxigênio, sendo consideradas as primeiras 20 vias ranqueadas pelo valor do número de genes regulados por via (Figura 33). Ambos os grupos, Alto e Baixo $\mathrm{O}_{2}$, apresentaram uma grande quantidade de vias relacionadas com câncer. Além disso, entre as vias enriquecidas pelos miRNAs menos expressos na alta tensão de oxigênio destaca-se a via de sinalização FOXO, relacionada com resposta ao estresse oxidativo. 


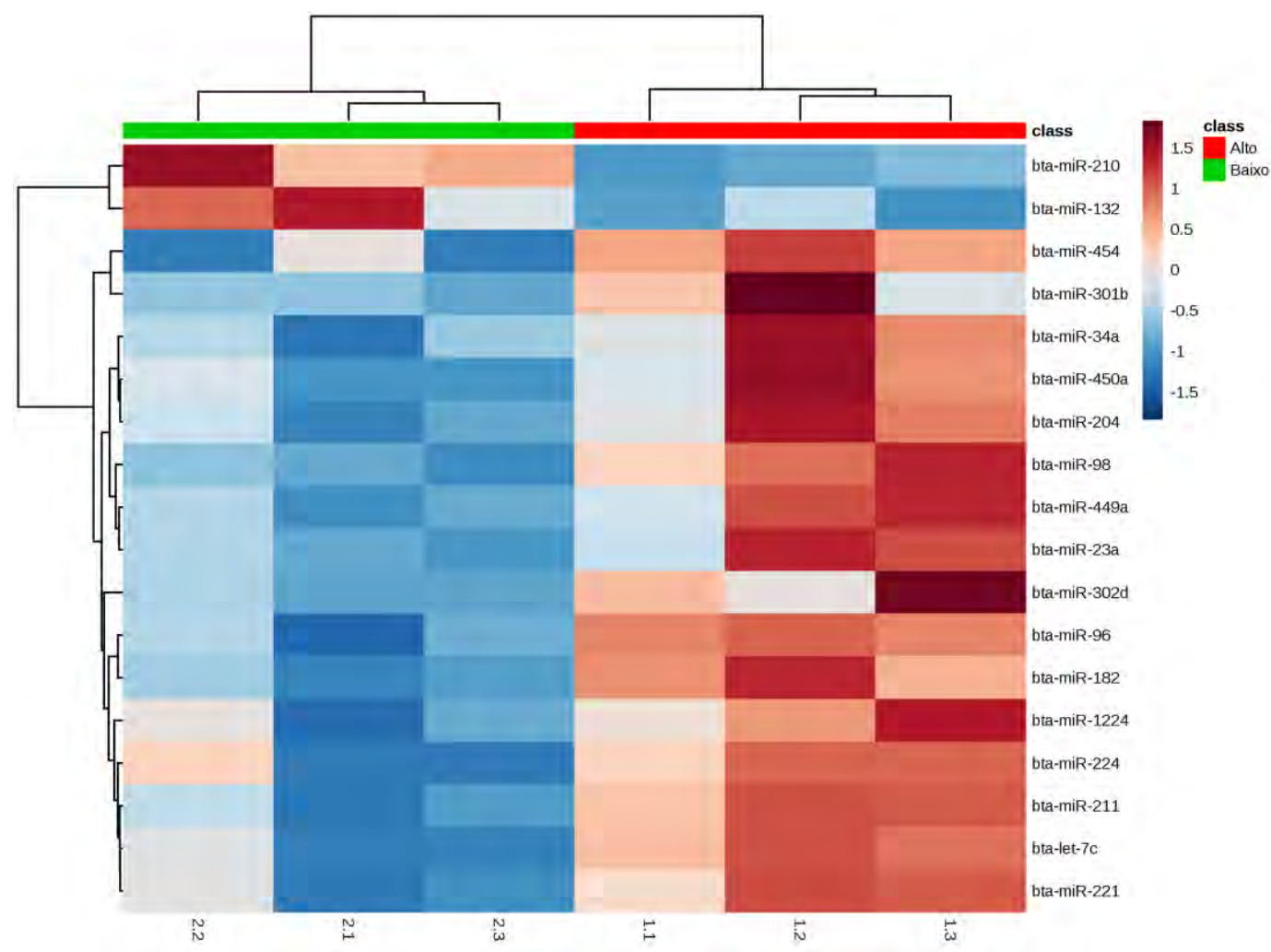

Figura 32. Heatmap indicando 18 miRNAs diferentemente presentes $(p \leq 0,05)$ no conteúdo de exossomos isolados do meio de cultivo de produção in vitro de embriões desenvolvidos entre alta e baixa tensão de oxigênio no dia 7 do cultivo, para três repetições biológicas.

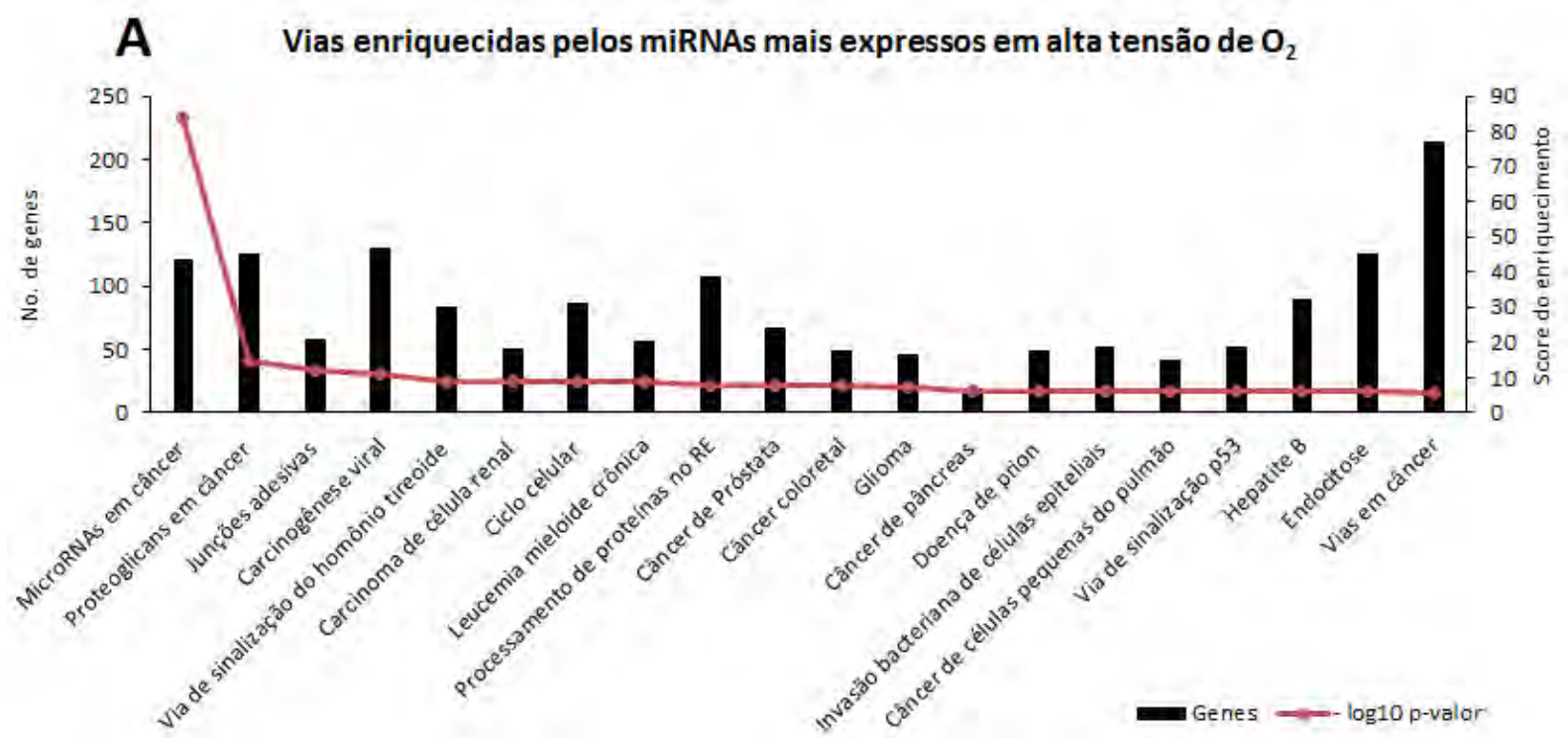


B Vias enriquecidas pelos miRNAs menos expressos em alta tensão de $\mathrm{O}_{2}$

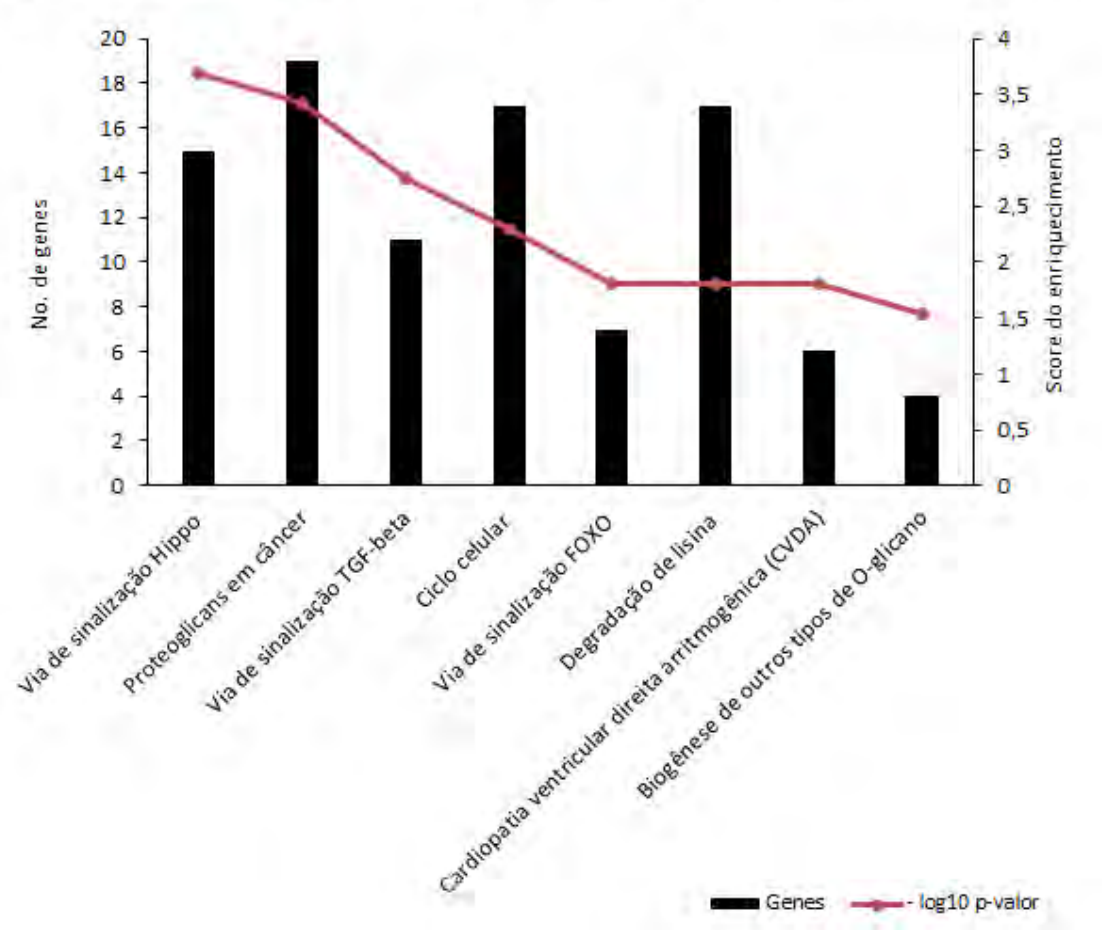

Figura 33. Principais vias enriquecidas pelos miRNAs elevados (A) e diminuídos (B) em exossomos isolados do meio de cultivo no dia 7 na alta tensão de oxigênio em relação a baixa tensão de oxigênio para três repetições biológicas. Os valores do eixo $Y$ da esquerda representam o número de genes enriquecidos pelos miRNAs para as respectivas vias, enquanto o eixo $\mathrm{Y}$ da direita representa o valor de enriquecimento do score para cada via. $\mathrm{O}$ valor de enriquecimento de score é o - $\log _{10}$ do valor de $p$, que é um valor extraído do algoritmo do software DIANA TOOLS com base na proporção de simulações de alvos para os miRNAs. 


\section{Discussão}

\subsection{Experimento I}

\subsubsection{Estresse oxidativo}

Nos resultados deste trabalho as diferentes tensões de oxigênio não alteraram as taxas de clivagem e de blastocisto durante o desenvolvimento embrionário in vitro. Os resultados de Harvey et al. (2004), Pontes (2009) e Gaspar et al. (2015) são semelhantes, as taxas de clivagem e blastocisto não são diferentes entre a alta e a baixa tensão. Entretanto, outros estudos mostram que apesar da taxa de clivagem não variar entre a alta e baixa tensão, as taxas de blastocisto, em geral, são menores na alta tensão em comparação com a baixa tensão de oxigênio (DUMOULIN et al., 1999; AMIN et al., 2014; YOON et al., 2014). Neste estudo foi empregado um sistema de cultivo embrionário com a adição de soro fetal bovino depletado de vesículas extracelulares e com o emprego do pseudo-co-cultivo com células do cumulus. $\mathrm{O}$ efeito benéfico do cocultivo durante o desenvolvimento embrionário in vitro já é conhecido, atuando na redução dos danos oxidativos sobre o embrião ou no intercâmbio de fatores de crescimento que auxiliam no desenvolvimento do embrião (WYDOOGHE et al., 2015). Recentemente, a utilização de SFB depletado de vesículas extracelulares do SFB também tem sido vinculado a um efeito benéfico durante desenvolvimento embrionário (LOPERA-VASQUEZ et al., 2017). Assim, nas condições de cultivo empregadas neste trabalho não houve diferença nas taxas de desenvolvimento embrionário, e as condições particulares empregadas no cultivo impedem uma comparação plena com resultados já descritos.

Os resultados de acúmulo de EROs demonstraram que o desenvolvimento embrionário bovino in vitro realizado em alta tensão de oxigênio gera maiores níveis de espécies reativas de oxigênio comparado com o cultivo em baixa tensão de oxigênio. 0 estresse oxidativo é um distúrbio no estado de equilíbrio pró-oxidante e antioxidante nas células, consequentemente diversos estudos associaram diretamente o nível de estresse com a presença de EROs, relacionando o excesso de EROs com baixa qualidade embrionária e atraso no desenvolvimento (CROCOMO et al., 2012; AMIN et al., 2014). Este estudo identificou acúmulo de EROs no sistema de cultivo de alta tensão em relação a baixa tensão 
de oxigênio, permitindo determinar que o excesso de oxigênio durante o desenvolvimento embrionário é capaz de gerar estresse oxidativo celular.

\subsubsection{Provável regulação do miR-199a sobre a via ERBB}

Estudos de Dumoulin et al. (1999), Pontes (2009) e Bontekoe et al. (2012) demonstraram uma diferença significativa entre as taxas de animais gestantes de embriões cultivados em alta ou baixa tensão de oxigênio, na qual a alta tensão apresenta uma taxa menor em relação a baixa tensão. Tais resultados sugerem que a baixa tensão de oxigênio favorece o desenvolvimento e a implantação embrionária. A fim de compreender os prováveis mecanismos de interação materno-embrionária que o estresse oxidativo pode alterar, de modo a comprometer as taxas de gestação, este estudo propôs-se a estudar a via ERBB e sua regulação pós-transcricional. A via de sinalização do ERBB apresenta função importante na interação materno-embrionária a partir da interação dos receptores da família das ERBBs, presentes na membrana do trofoblasto e os ligantes das células do estroma do endométrio, como as NRGs (REESE et al., 1998; BROWN et al., 2004).

Estudo de He e colaboradores (2012) demonstrou a regulação dos receptores ERBB2 e ERBB3 pelo miR-199-5p em células de tumor de mama, entretanto, apesar da expressão do miR-199a-5p ser maior nos blastocistos cultivados em alta tensão comparado aos de baixa tensão, a proteína ERBB2 não variou de expressão entre os grupos. A alta presença do miR199a-5p não diminuiu a expressão do receptor ERBB2, sugerindo que o transcrito ERBB2 bovino provavelmente não é um gene alvo do miR-199a-5p. Em contrapartida, Tan et al. (2016) caracterizaram que a inibição do miR-199a-5p diminui a taxa de gestação a termo e a razão ICM/TE (razão entre a quantidade de células que compõem a massa celular interna (ICM) e trofoblasto (TE)) em embriões de camundongo. A expressão do miR-199a-5p pode ser associada com a manutenção do potencial desenvolvimento e viabilidade embrionário. Este estudo detectou o aumento da expressão do miR-199a5p em embriões cultivados na alta tensão de oxigênio. Contudo, mais estudos são necessários para compreender a função e os mecanismos de atuação do miR-199a-5p em embriões submetidos a condições de estresse oxidativo.

Com o objetivo avaliar se os anticorpos para as proteínas ERBB2 e ERBB3 correspondiam realmente à estes receptores foi realizada a imunolocalização das proteínas. 
As imagens geradas pela análise permitiram a identificação de uma região que não foi marcada pelos anticorpos, identificada como camada de Rauber (Figura 13). A camada de Rauber foi descrita por Betteridge e Flechon (1988) como a ausência de células do trofoblasto na região polar do embrião na qual se encontra a massa celular interna. A ausência de marcação dos receptores ERBB2 e ERBB3 na camada de Rauber demonstrou a presença exclusiva dessas proteínas nas células do trofectoderma do embrião bovino, o que vai de acordo com a descrição de Brown et al. (2004) sobre os receptores ERBB2 e ERBB3 em embriões bovinos e atesta a eficácia de identificação destas proteínas pelos anticorpos utilizados.

A sinalização da via ERBB depende primariamente da ativação dos receptores ERBB, que ocorre através de sinalização hormonal ou interação com neutransmissores (YARDEN; SLIWKOWSKI, 2001; ONO; KUWANO, 2006). Este estudo não encontrou diferença de expressão dos transcritos ERBB2 e ERBB3 entre os embriões desenvolvidos em alta e baixa tensões de oxigênio. A especificidade e a potência dos sinais transmitidos pelos receptores ERBB depende da composição de homo e heterodímeros da membrana celular, uma vez que o heterodímero ERBB2/ERBB3 apresenta função de sinalização após a fosforilação enquanto homodímero ERBB2 não possui ligante específico e não gera sinal eficaz para os fatores de crescimento (BAECKSTROM; ALFORD; TAYLOR-PAPADIMITRIOU, 2000; YARDEN; SLIWKOWSKI, 2001). Além disso, a associação das proteínas em homo ou heterodímeros depende do equilíbrio entre monômeros e dímeros de ERBB2, de acordo com Nagy et al. (2002) as áreas da membrana com alta homodimerização da proteína ERBB2 estão positivamente relacionadas com a densidade local de ERBB2 e inversamente relacionadas com a densidade local de ERBB3. Este estudo não detectou diferença significativa nos níveis da proteína ERBB2 entre os embriões cultivados em alta e baixa tensão de oxigênio. Entretanto, para indicar a potência do sinal gerado pela via ERBB o estudo de outros receptores da via é indispensável.

A função final da via ERBB, no entanto, é composta pela ação conjunta com outras vias, como a PI3K/AKT e MAPK (mitógeno ativado quinase-like) (YARDEN; SLIWKOWSKI, 2001; ONO; KUWANO, 2006). Este estudo encontrou no experimento II um aumento da expressão do transcrito MAPK1 na alta tensão em comparação com a baixa tensão de oxigênio. Em síntese, este estudo demonstrou que os elevados nos níveis de EROs e do miR199a-5p não induziram alterações significativas nos níveis do ERBB2 (RNAm e proteína). 
Portanto, são necessários mais estudos para compreender como o estresse oxidativo interfere na sinalização da via ERBB.

\subsubsection{Tratamento com antioxidantes}

A suplementação do meio de cultivo in vitro de embriões com agentes antioxidantes, como a cisteína e a cisteamina, é amplamente utilizada nos sistemas de cultivo com o objetivo de reduzir os efeitos deletérios do estresse oxidativo. Este estudo demonstrou que o uso de antioxidantes diminuiu de forma eficaz os níveis de EROs, de modo semelhante ao demonstrado por De Matos, Furnus e Moses (1997), Gasparrini et al. (2006) e Rocha-Frigoni (2016). De modo similar a Rocha-Frigoni (2016) este estudo não observou diferença entre as taxas de clivagem e blastocisto entre os grupos de alta tensão de oxigênio e alta tensão com C+C. Em geral, o tratamento com cisteína e cisteamina leva ao aumento do antioxidante GSH em oócitos maturados. Os acúmulo de GSH é responsável pela redução dos níveis de EROs. Dessa forma, é possível afirmar que o tratamento $C+C$ proposto foi eficaz no combate do estresse oxidativo induzido por EROs.

A análise das isoformas do miR-199a demonstrou que conforme observado para a alta e a baixa tensão de oxigênio o miR-199a-3p não apresentou diferença significativa entre os grupos cultivados em alta tensão na ausência e presença de antioxidantes. A comparação da expressão transcritos ERBB2 e ERBB3 também não apresentou resultados significativamente diferentes entre os grupos de alta tensão de oxigênio e alta tensão com $C+C$, de modo similar ao observado neste estudo para alta e baixa tensão de oxigênio. $A$ expressão da proteína ERBB2 não foi estatisticamente diferente entre os grupos, da mesma forma como observado entre os grupos de alta e baixa tensão. É importante ressaltar que não existem relatos anteriores de mensuração da expressão das isoformas do miR-199a ou transcritos e proteínas da via ERBB para embriões tratados com cisteína e cisteamina. Os resultados apresentados anteriormente demonstram que a suplementação com cisteína e cisteamina, embora tenha reduzido os níveis de EROs nos blastocistos bovinos, não mimetizaram a expressão do miR-199a-5p observada no grupo Baixo $\mathrm{O}_{2}$. Desta forma, é possível sugerir que a suplementação do meio de cultivo com cisteína e cisteamina não controla completamente os efeitos do estresse oxidativo sobre as células dos embriões bovinos. Portanto, são necessários mais estudos sobre o efeito de outros antioxidantes 
sobre a expressão dos miRNAs em embriões produzidos in vitro em diferentes condições de cultivo.

\subsubsection{Conclusão}

A alta tensão de oxigênio durante o cultivo de embriões bovinos foi capaz de gerar um modelo de estresse oxidativo eficiente a partir do aumento dos níveis de EROs. Apesar do estresse oxidativo ser capaz de alterar a expressão do miR-199a-5p, não foram observadas alterações significativas nos níveis de $E R B B 2$ e $E R B B 3$, bem como nos níveis da proteína ERBB2. A partir dos resultados apresentados não há indicação que os níveis de miR-199a-5p atuem como regulador pós-transcricional do ERBB2 para embriões bovinos. Como a sinalização da via ERBB depende tanto da conformação de homo e heterodímeros da membrana e da sinalização de outras vias, os resultados demonstrados não permitem inferir sobre a interação materno-embrionária mediada por ERBB ou os efeitos do estresse oxidativo nesta interação. Outros estudos são necessários para compreender como o estresse oxidativo interfere no potencial de implantação do embrião, comprometendo as taxas de gestação de embriões cultivados em alta tensão de oxigênio.

\subsection{Experimento II}

\subsubsection{Efeitos do estresse oxidativo no embrião: RNAm relacionados com remodelação epigenética $x$ miRNAs}

Com objetivo de avaliar os níveis globais de metilação do DNA, os blastócitos foram avaliados por imunocitoquímica para 5-mC. Os resultados relaram uma hipermetilação do DNA dos blastocistos desenvolvidos in vitro em alta tensão em comparação com a baixa tensão de oxigênio, confirmando a hipótese de que o estresse oxidativo aumenta os níveis globais de metilação do DNA. Li et al. (2014) relataram um aumento do padrão de metilação global semelhante, entretanto a comparação foi entre embriões produzidos in vitro (cultivados em alto $\mathrm{O}_{2}$ ) e produzidos in vivo. Além disso, Yamanaka e colaboradores (2011) demonstraram a ausência de diferença no padrão de metilação entre embriões produzidos in vitro sob baixa tensão de oxigênio (5\%) e embriões in vivo. A hipótese deste estudo é de 
que os embriões de baixa tensão de oxigênio seriam mais semelhantes aos embriões in vivo, uma vez que no oviduto e no útero a tensão de oxigênio é baixa (aproximadamente de 5 a 7\%). Os resultados deste estudos, juntos com os de Li et al. (2014) e os de Yamanaka et al. (2011) confirmam essa hipótese. Portanto, em relação aos níveis de metilação do DNA após a reprogramação epigenética, os embriões bovinos produzidos in vitro em baixo $\mathrm{O}_{2}$ podem ser considerados semelhantes aos embriões produzidos in vivo.

Uma vez que os níveis de metilação do DNA dos blastocistos estavam alterados, espera-se encontrar também alterações na expressão dos transcritos. O presente estudo avaliou a expressão de 96 RNAm, a partir deles 40 transcritos foram considerados diferentemente expressos entre alta e baixa tensões de oxigênio. Este resultado confirmou a hipótese de que o estresse oxidativo altera efetivamente a expressão de transcritos relacionados com resposta ao estresse oxidativo, proliferação e diferenciação celular, remodelação epigenética, apoptose, metabolismo e reconhecimento materno-fetal. 7 dos RNAm (DNMT3A, HDAC2, H2AFZ, H3F3B, MOFF4L2, REST e PAF1) possuem função envolvida com remodelação epigenética e estão mais expressos na alta tensão em comparação com a baixa tensão (Figura 18). A alteração desses mecanismos indica que a alta tensão de oxigênio é capaz de interferir na reprogramação epigenética através da modulação da expressão de transcritos ligados a processos de metilação e aceitação do DNA e proteínas histonas durante o desenvolvimento embrionário.

Os transcritos DNMT3A e PAF1 foram elevados na alta tensão de oxigênio em comparação a baixa tensão. A DNMT3A realiza a resposta primária da atividade de metilação de novo, preferencialmente nas ilhas de metilação (CpGs), processo essencial durante a reprogramação epigenética para estabelecimento do padrão de metilação do embrião, permitindo a ativação do genoma embrionário (OKANO; XIE; LI , 1998; UYSAL; AKKOYUNLU; OZTURK, 2015). A ausência da DNMT3A tem sido associada a letalidade ou desenvolvimento embrionário defeituoso (OKANO et al., 1999). O PAF1 (componente homólogo PAF1 do complexo RNA polimerase II) está envolvido no processo de metilação das proteínas histonas. Distúrbios na expressão do PAF1 têm sido relacionado com defeitos no desenvolvimento cardíaco e neuronal em peixes-zebra (KROGAN et al., 2003; NGUYEN et al., 2010). Entretanto, em camundongos a menor expressão da PAF1 é essencial para a diferenciação celular no processo de blastulação (DING et al., 2009). García et al. (2016) demonstraram um aumento da expressão de PAF1 em células de leveduras expostas a 
condições de estresse oxidativo da mesma forma que este estudo. Em suma, o aumento da expressão da DNMT3A e PAF1 podem corroborar com o resultado do padrão de aumento da metilação encontrado nos embriões cultivados em alta tensão de oxigênio.

As análises de bioinformática deste trabalho e os estudos de Fabbri et al. (2007) indicaram uma regulação predita dos membros da família miR-29 sobre os transcritos DNMT3A e DNMT3B. Este estudo não encontrou alterações significantes da expressão da família miR-29 entre os grupos de embriões cultivados em alta ou baixa tensão de oxigênio. Contudo, uma vez que os transcritos de DNMT3A foram elevados no grupo de alta tensão em comparação ao grupo baixa, a ausência de diferença de expressão no miR-34b e na família miR-29 entre estes grupos pode indicar que os níveis da proteína DNMT3A estarão alterados de modo semelhante à expressão do transcrito. Estudos dos níveis da proteína de DNMT3A são necessários para confirmar essa hipótese.

Conforme demonstrado neste estudo a atmosfera de alta tensão de oxigênio favorece o acúmulo de EROs. O aumento dos níveis de EROs tem sido associado por diversos autores, como He et al. (2012) e Li et al. (2014), ao aumenta a expressão da DNA metiltransferase 1 (DNMT1), respectivamente em células tumorais e embriões bovinos. Entretanto este estudo não identificou diferenças significativas na expressão da DNMT1 para os embriões cultivados em alta e baixa tensão de oxigênio. Essa ausência de alteração pode ser justificada por meio regulação pós-transcrição pelo bta-miR-155. O miR-155 foi descrito por Zhang et al. (2015) como regulador efetivo entre do DNMT1 em células renais humanas. Como neste estudo o miR-155 foi mais expresso no grupo de alta tensão em relação ao grupo de baixa tesão e o transcrito DNMT1 não apresentou diferença de expressão entre os grupos, é possível sugerir que o aumento da expressão do miR-155 na alta tensão de oxigênio foi capaz de modular a expressão da DNMT1 em blastocistos bovinos, e por isso não foi observado a diferença significativa de expressão do RNAm DNMT1.

A expressão dos miRNAs também pode ser modulada por alterações epigenéticas. Conforme demonstrado por He et al. (2012), o aumento dos níveis de metilação das ilhas CpGs foi capaz de diminuir a expressão de miRNAs. Este estudo relatou a menor expressão do miR-210 em embriões cultivados em alta tensão de oxigênio de modo similar ao descrito por Xiong et al. (2012). O miR-210 promove a função anti-apoptose em células cancerígenas, além de ser considerado como uma assinatura da condição de hipóxia (KULSHRESHTHA et al., 2007). A metilação do DNA é capaz de diminuir os níveis do miR-210 sob condições de 
normóxia e hipóxia (XIONG et al., 2012). Este estudo apresentou o aumento nos níveis dos transcritos relacionados com promoção da metilação do DNA, como o DNMT3A e PAF1, em embriões cultivados em alta tensão de oxigênio. A alta expressão destes transcritos explica o aumento dos níveis de metilação dos blastocistos cultivados em condição de extresse oxidativo. Estas alterações epigenéticas, por sua vez, podem justificar a diminuição da expressão do miR-210 nos embriões cultivados em alta tensão de oxigênio.

\subsubsection{Efeito do estresse oxidativo no embrião: RNAm relacionados com estresse oxidativo $x$ miRNAs}

Com o objetivo de compreender a resposta celular do embrião ao estresse oxidativo gerado pela alta tensão de oxigênio este estudo isolou, a partir dos 40 RNAm diferentemente expressos entre os modelos de cultivo de alta e baixa tensão de $\mathrm{O}_{2}, 12$ transcritos relacionados com resposta ao estresse oxidativo. Os 12 transcritos (SOD1, CAT, TXN, TNFRSF21, PRDX1, PRDX3, NRF2, KEAP1, HSP9OAA1, GLRX2, PTGS2 e PPARG) estavam mais expressos na alta tensão de oxigênio em relação a baixa, indicando um possível mecanismo de compensação do estresse oxidativo (Figura 18). Os transcritos SOD1 (superoxide dismutase), CAT (catalase) e TXN (thioredoxin) destacaram-se por estarem de acordo com os resultados de Amin et al (AMIN et al., 2014), que relatou um aumento destas enzimas antioxidantes no cultivo embrionário em $20 \%$ de oxigênio e os associou com mecanismos que combatem ao acúmulo de EROs (Figura 34). O SOD 1 é uma enzima que catálisa a reação de dismutase para remoção das EROs. A CAT está associada com a catalise da reação de decomposição de $\mathrm{H}_{2} \mathrm{O}_{2}$ em água (HARVEY et al., 1995; HALLIWELL; GUTTERIDGE, 2015). A TXN é uma proteína de ubiquitinação da reação de redutase do dissulfito, que a partir do processo de redução combate o estresse oxidativo induzido pelas EROs. O bloqueio da expressão de TXN tem sido associado a falhas no desenvolvimento da massa celular interna e morte embrionária logo após a transferência, reforçando a importância dessa enzima no processo do desenvolvimento embrionário (MATSUI et al., 1996; BING et al., 2003). Dessa forma, é possível considerar que o aumento da expressão dos transcritos SOD1, TXN e CAT tem o objetivo de melhorar a qualidade e a competência dos embriões submetidos a condições estresse oxidativo. 


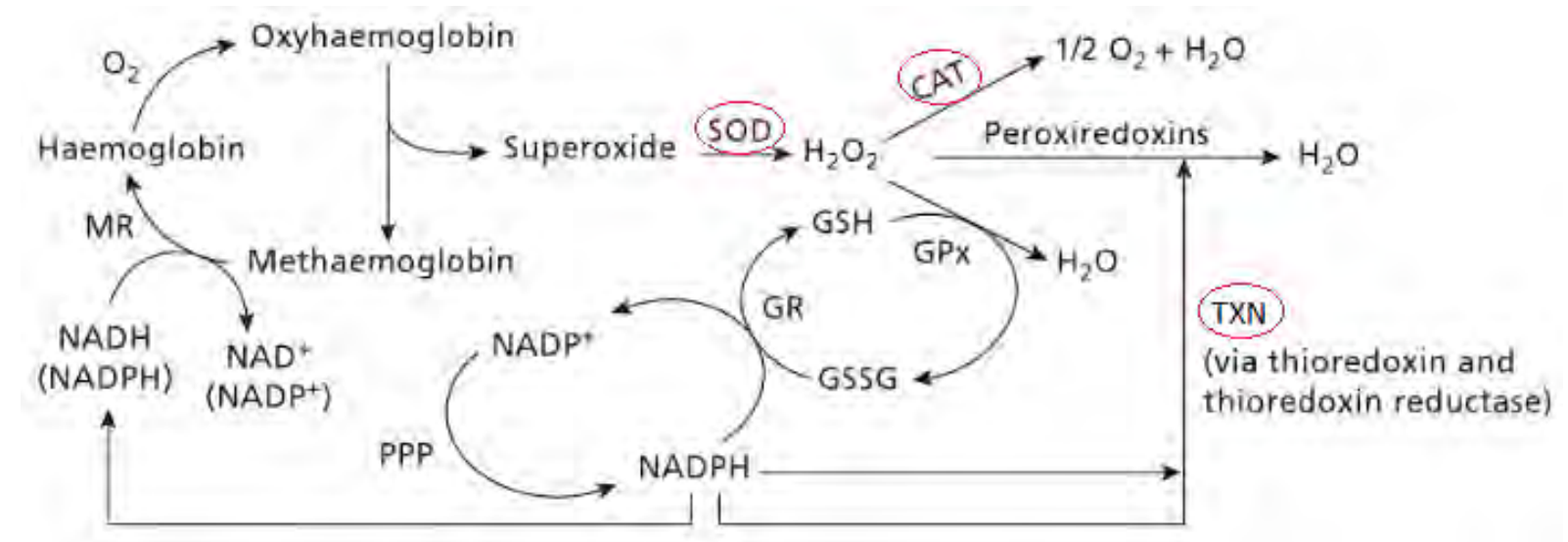

Adaptado de Halliwell e Gutteridge (2015, p.361)

Figura 34. Esquema ilustrativo das reações catalisadas pelas enzimas SOD1, CAT e TXN (em destaque) como resposta ao estresse oxidativo induzido pelo excesso de EROs, durante o metabolismo celular.

Os resultados do enriquecimento das vias pelos miRNAs mais expressos na alta tensão de oxigênio indicaram a regulação da via de sinalização FOXO (subclasse O da família forkhead de fatores de transcrição) ligada à resposta ao estresse oxidativo. A via de sinalização FOXO atua em conjunto com vias como a via da insulina e a via PI3K/AKT desencadeando a ativação da transcrição das enzimas antioxidantes CAT e SOD1 e, consequentemente, resistência ao estresse oxidativo (Figura 35) (HALLIWELL; GUTTERIDGE, 2015; VLACHOS et al., 2015). Conforme demonstrado por estudos prévios, a alta tensão de oxigênio condiciona um agravamento do estresse oxidativo devido a uma elevada concentração de EROs gerada pelo metabolismo celular e pela deficiência dos mecanismos antioxidantes (DE MATOS et al., 1996; GASPARRINI et al., 2006). O enriquecimento da via de sinalização FOXO pelos miRNAs mais expressos na alta tensão de oxigênio sugere que o estresse oxidativo induz a alterações na regulação da via FOXO, aparentemente compensadas através do aumento da transcrição de CAT e SOD1, também observada no grupo de alta tensão em comparação com a baixa tensão de oxigênio. 


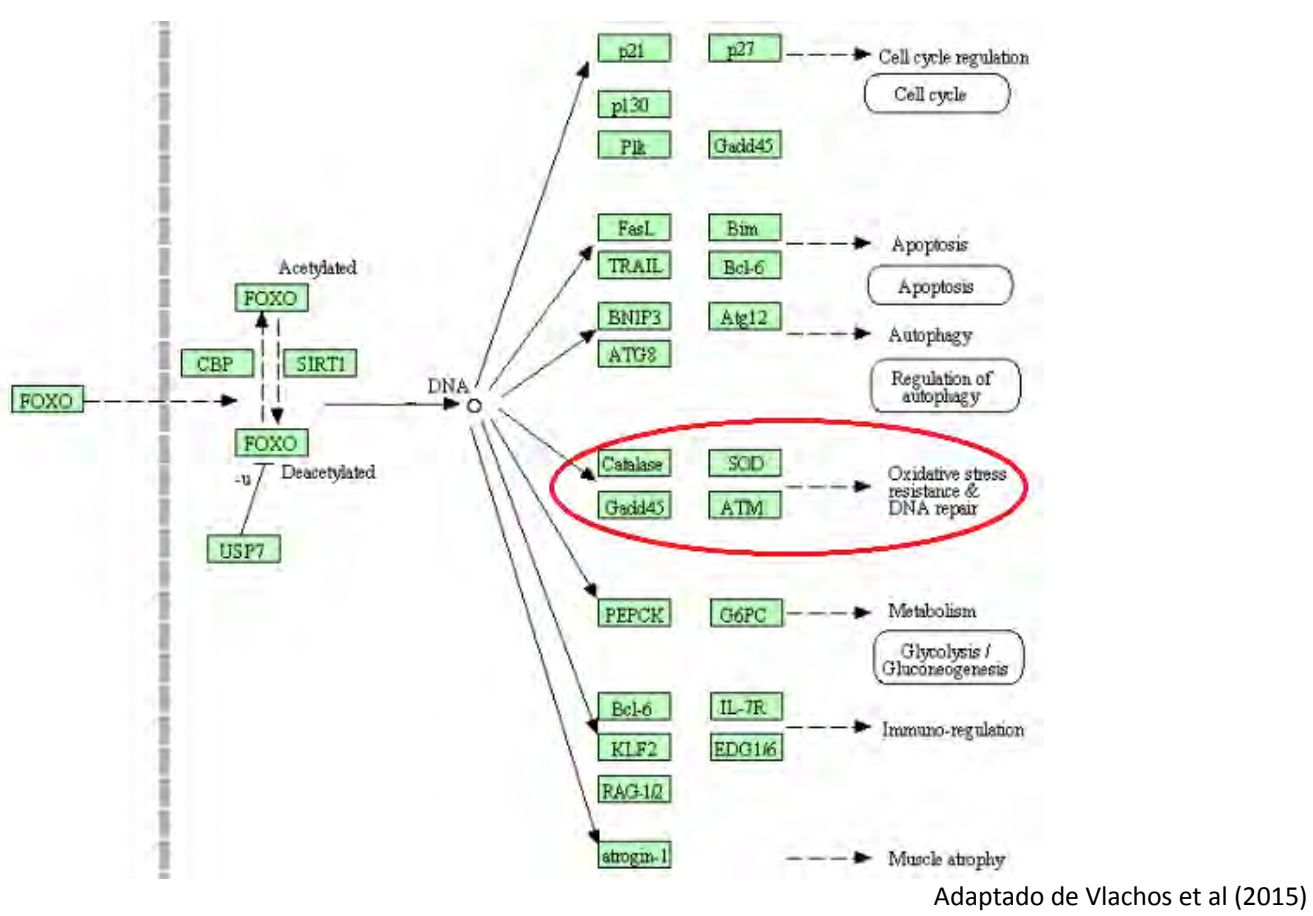

Figura 35. Esquema ilustrativo da via de sinalização FOXO, no qual foi destacada a função de resposta ao estresse oxidativo.

O conjunto dos resultados auxilia na validação do modelo de estresse oxidativo para o cultivo embrionário, demonstrando que a exposição dos embriões à alta tensão de oxigênio durante o desenvolvimento é capaz de gerar uma resposta de estresse oxidativo celular mediado por EROs. Desta forma, é possível inferir que em resposta às alterações induzidas pelo estresse oxidativo no embrião ocorre um aumento da expressão de agentes antioxidantes, como SOD1, CAT e TXN, que tem o objetivo reduzir os níveis de EROs e restabelecer o equilíbrio entre os agentes pró-oxidante e antioxidante nas células. Dessa forma, as alterações ligadas ao sistema de resposta ao estresse oxidativo favorecem a qualidade e a progressão do desenvolvimento de embriões expostos à alta tensão de oxigênio.

Os resultados do enriquecimento de vias pelos miRNAs mais expressos na alta tensão de oxigênio demonstraram a presença de vias de câncer, como câncer pancreático e câncer de próstata, além da via da leucemia mieloide crônica. O transcrito STAT3 (transdutor de sinal e ativador da transcrição 3), mais expresso na alta tensão em comparação com a baixa tensão de oxigênio, foi associado as vias de câncer de pâncreas e leucemia mieloide crônica promovendo as funções de angiogênese e anti-apoptótica, respectivamente. Os resultados estão de acordo com Li e colaboradores $(2004,2010)$, que relataram o aumento dos níveis 
de STAT3 mediante condições de estresse oxidativo induzido por EROs em células tumorais humanas. O STAT3 é frequentemente ligado a funções de proliferação ou promoção da sobrevivência celular responsivo a citocinas (DARNELL JR; KERR; STARK, 1994; LI, Li et al., 2010). Este estudo não encontrou microRNAs significativamente alterados pelo estresse oxidativo para o gene alvo STAT3. O transcrito HSP9OAA1 (Proteína 1 Heat Shock 90kd), mais elevado na alta tensão em relação a baixa tensão de oxigênio, foi correlacionado com a via de câncer de próstata intermediando a função de proliferação, provavelmente, através da atividade de organização de subunidades do complexo celular para progressão do ciclo mitótico (WANDINGER; RICHTER; BUCHNER , 2008). Além disso, a HSP90 é descrita como uma proteína chaperona altamente conservada responsável pela regulação da homeostase e resposta ao estresse oxidativo, e caracterizada pela alta expressão celular (FRANCO et al., 2013). Os resultados desde estudo concordam com o aumento de HSP9O induzido pelo estresse oxidativo observado por Liu et al. (2016), que também associou a inibição de HSP9O com indução da morte de células submetidas a condições de estresse. Este estudo não encontrou microRNAs significativamente alterados pelo estresse oxidativo para o gene alvo HSP9OAA1. Neste contexto, é possível sugerir que o aumento nos níveis dos transcritos STAT3 e HSP9OAA1 tem o objetivo de favorecer a viabilidade dos embriões submetidos a condições de estresse oxidativo.

Para avaliar a eficácia do tratamento com antioxidantes em reverter as alterações induzidas pelo estresse oxidativo, os 8 miRNAs (bta-miR-378b, bta-miR-34c, bta-miR-19a, bta-miR-155, bta-miR-1260b, bta-miR-22-5p, bta-miR-210 e bta-miR-140) que apresentaram diferença significativa de expressão entre os grupos de embriões cultivados em alta e baixa tensões de oxigênio foram avaliados para dois grupos submetidos a condições de alta tensão de oxigênio na ausência e presença de antioxidantes. O tratamento com cisteína e cisteamina é comumente utilizado para aumentar os níveis de glutationa intracelular, o que aumenta a atividade de neutralização das EROs (DE MATOS; FURNUS; MOSES, 1997; ROCHAFRIGONI, 2016). Uma vez que os níveis de EROs foram reduzidos após o uso dos antioxidantes, de modo semelhante ao observado anteriormente no grupo de Baixo $\mathrm{O}_{2}$, esperava-se observar uma expressão de miRNAs também semelhante à baixa tensão de $\mathrm{O}_{2}$. No entanto, a expressão dos miRNAs não apresentou diferença significativamente entre os grupos de alta tensão de oxigênio e alta tensão com $C+C$. Portanto, apesar da suplementação do meio de cultivo com cisteína e cisteamina ser eficiente na diminuição das 
EROs, conforme demonstrado nesse estudo, ela não mimetizou a expressão de miRNAs observada na baixa tensão de oxigênio.

Em suma, o presente estudo propôs a investigação inédita da expressão dos miRNAs em embriões bovinos produzidos in vitro expostos à condições de estresse oxidativo e suplementados com antioxidantes. Os resultados observados permitem inferir que o uso de cisteína e cisteamina no meio de cultivo não previne todas as alterações causadas pelo estresse oxidativo gerado pela alta tensão de $\mathrm{O}_{2}$. Estudos sobre outros antioxidantes, com diferentes princípios de ação, são necessários para compreender como o estresse oxidativo modula a expressão de miRNAs durante a produção in vitro de embriões e para a seleção de uma suplementação com antioxidantes mais eficiente contra os efeitos do estresse oxidativo.

\subsubsection{Conclusões}

A alta tensão de oxigênio durante o cultivo de embriões bovinos foi capaz de gerar um modelo de estresse oxidativo eficiente para avaliação molecular em blastocistos produzidos in vitro. O estresse oxidativo gerou o aumento da metilação global nos blastocistos e alterou a expressão de 40 transcritos e 8 miRNAs. Entre as principais vias e funções alteradas destacam-se as vias de modulação epigenética, resposta ao estresse oxidativo e proliferação celular. Entre os transcritos ligados a alterações epigenéticas, o aumento da expressão dos transcritos DNMT3A e PAF1 nos blastocistos cultivados na alta tensão de oxigênio pode justificar o padrão de hipermetilação observado nestes embriões. Estas modificações epigenéticas observadas podem justificar a menor expressão do miR-210 na alta tensão de oxigênio. A maior expressão do miR-210 na baixa tensão de oxigênio (5\%) confirma o seu potencial como assinatura da condição de hipóxia. Por sua vez, o aumento da expressão dos transcritos ligados a resposta ao estresse oxidativo e proliferação celular nos embriões cultivados em alta tensão de oxigênio têm o objetivo de favorecer o potencial de sobrevivência e desenvolvimento dos embriões. Além disso, a investigação da eficácia do tratamento com cisteína e cisteamina em reverter as alterações de miRNAs causadas pelo estresse oxidativo não gerou resultados consistentes. Neste estudo a suplementação com cisteína e cisteamina não reverteu as alterações de expressão de RNAm observadas em embriões cultivados em condição de estresse oxidativo. 


\subsection{Experimento III}

\subsubsection{Padrão de secreção dos exossomos presentes no meio de cultivo de embriões bovinos nos dias 3 e 7}

A descoberta da comunicação mediada por exossomos proporcionou um novo panorama para o estudo da comunicação bidirecional intercelular no ambiente de cultivo in vitro. O presente estudo teve como objetivo avaliar o padrão de secreção dos exossomos no ambiente in vitro de cultivo de embriões de forma semelhante ao realizado por Saadeldin et al. (2014) para embriões suínos. Os resultados do tamanho dos exossomos não demonstraram diferença entre os grupos de alta $(117,8 \mathrm{~nm})$ e baixa tensão $(124,6 \mathrm{~nm})$ de $\mathrm{O}_{2}$ em D3 e apresentaram tamanho compatível com o diâmetro dos poros da zona pelúcida observados nas fases de zigoto (223 nm) e 8 células (203 nm) (VANROOSE et al., 2000).

Os exossomos isolados do meio de cultivo até D7 também não apresentam diferença significativa nos tamanhos dos exossomos entre a alta $(112,24 \mathrm{~nm})$ e a baixa (107,1 nm) tensão de oxigênio. Apesar da diminuição do tamanho das partículas entre os dias 3 e 7 do cultivo ser oposta ao observada por Saadeldin et al. (2014) em embriões suínos, ela está de acordo com os resultados de diminuição dos poros da zona pelúcida no estágio de mórula em relação aos estágios iniciais do desenvolvimento embrionário demonstrados por Vanroose et al. (2000). Além disso, de forma semelhante ao observado em D3, no D7 os exossomos também apresentam tamanho compatível com os poros da zona pelúcida no estágio de mórula (155 nm). Quando avaliados juntos, estes resultados permitem sugerir que exossomos presentes próximos aos embriões bovinos possuem o potencial de transpor a zona pelúcida durante os estágios de zigoto, oito células e mórulas em condições de cultivo in vitro de alta e baixa tensão de oxigênio.

A concentração de exossomos no meio de cultivo até o dia 3 do desenvolvimento foi menor na alta tensão em comparação com a baixa tensão de $\mathrm{O}_{2}$. Estudos de King, Michael e Gleadle (2012) e Salomon (2013) evidenciaram que a baixa tensão de oxigênio promove um aumento da concentração de exossomos liberados por células tumorais com alta capacidade metastática, que estimulam a progressão do desenvolvimento tumoral. A diminuição da concentração de exossomos observada na alta tensão de oxigênio pode, portanto, ser associado a um déficit na comunicação provocado pelo estresse oxidativo. 
Após sete dias de cultivo, entretanto, o meio de cultivo da alta tensão apresentou maior concentração de exossomos em relação à baixa tensão de $\mathrm{O}_{2}$. Os resultados de Vanroose e colaboradores (2000) reportaram o aumento na quantidade de poros durante o estágio de mórula. O aumento da concentração de exossomos e o aumento da quantidade de poros da zona pelúcida permitem sugerir que a comunicação entre as células é maior no terço final do desenvolvimento embrionário inicial. Quando comparados, os resultados de D3 e D7 sugerem que a exposição ao estresse oxidativo é capaz de alterar a concentração de partículas do meio de cultivo da produção in vitro de embriões. Apesar de inicialmente as condições de estresse oxidativo aparentarem dificultar a comunicação, no terço final do desenvolvimento inicial é possível observar um comportamento oposto, que sugere uma resposta celular à condição de estresse oxidativo prolongado, que pode impactar na qualidade dos embriões.

\subsubsection{Vias enriquecidas pelos miRNAs presentes no conteúdo dos exossomos do meio de cultivo nos dias 3 e 7}

Neste estudo avaliamos alterações encontradas na expressão dos microRNAs de exossomos isolados do meio de cultivo da produção in vitro de embriões bovinos na presença e ausência de condições de estresse oxidativo. Inicialmente foram identificados 15 e 18 microRNAs diferentemente expressos entre a alta e baixa tensão de $\mathrm{O}_{2}$ para os dias 3 e 7 do cultivo, respectivamente. Os resultados do enriquecimento das vias pelos miRNAs demonstraram que para todos os grupos, em D3 e D7, as vias com maior número de genes enriquecidos são vias de câncer. Em geral as vias de câncer são associadas a função de progressão do ciclo mitótico para promoção da proliferação celular, corroborando com a função anti-apoptose (VLACHOS et al., 2015). A associação entre os exossomos e a atividade de manutenção da sobrevivência celular foi previamente descrita por Ng et al. (2013) e Salomon et al. (2013), respectivamente nos cultivos de células uterinas e placentária. No entanto, o relato do enriquecimento de vias, com função de proliferação, baseado em microRNAs de exossomos obtidos do meio de cultivo in vitro de embriões é inédito.

A via de sinalização FOXO, ligada ao mecanismo de resposta ao estresse oxidativo, foi enriquecida pelos miRNAs elevados em vesículas do cultivo em alta tensão em comparação com a baixa tensão de oxigênio, em D3 e D7. Alterações induzidas pelo estresse oxidativo 
sobre o conteúdo de microRNAs e proteínas foram relatadas, respectivamente, por King, Michael e Gleadle (2012) em células de tumor e Salomon et al. (2013) em células de placenta. Os resultados deste estudo, portanto, corroboram com a hipótese que o estresse oxidativo é capaz de gerar alterações no conteúdo de miRNAs dos exossomos.

O miR-210 apresentou maiores níveis em exossomos do meio de cultivo submetido a baixa tensão de oxigênio (5\%), o mesmo resultado foi observado para os microRNAs nos blastocistos (conforme exposto nos resultados - experimento II: 6.2.3.). Os níveis elevados do miR-210 no ambiente de baixa tensão de oxigênio (1\%) em comparação com a alta tensão (20\%) também foi observada por King, Michael e Gleadle (2012) em células tumorais. Kulshreshtha et al. (2007) descreveram o miR-210 como uma assinatura da condição de hipóxia. No contexto do ambiente de cultivo da produção in vitro de embriões, o miR-210 pode ser indicado como uma assinatura molecular para estado de normoxia embrionária, uma vez que o oviduto e o útero materno apresentam tensões de oxigênio fisiológicas próximas de 5 a 7\% (FISCHER; BAVISTER, 1993; HARVEY, 2007). É importante ressaltar que não existem relatos anteriores de mensuração dos níveis de microRNAs em exossomos isolados do cultivo in vitro de embriões bovinos na presença e ausência de estresse oxidativo.

\subsubsection{Conclusões}

A diminuição da concentração dos exossomos observado no meio de cultivo em D3 da alta tensão, e o posterior aumento da concentração de partículas em D7 também para a alta tensão de oxigênio, permitem inferir que após exposição crônica o estresse oxidativo é capaz de alterar a comunicação intercelular no ambiente de cultivo in vitro de embriões bovinos. Além disso, o estudo permitiu a identificação do miR-210 indicado como biomarcador molecular não invasivo para estado de normoxia $\left(\begin{array}{llll}5 \% & \text { de } & \mathrm{O}_{2}\end{array}\right)$ do

desenvolvimento embrionário bovino. Estes dados reunidos permitem concluir que o estresse oxidativo é capaz de gerar alterações no cultivo in vitro de embriões, que refletem no conteúdo de miRNAs de exossomos presentes no meio de cultivo. De modo geral, o estudo contribuiu para a compreensão da atividade celular de embriões produzidos in vitro em condições de estresse oxidativo. 


\section{Conclusão}

O sistema de cultivo de alta tensão de oxigênio para embriões bovinos produzidos in vitro confirmou a hipótese inicial de que a alta tensão de oxigênio é capaz de gerar um modelo de estresse oxidativo que permite o estudo de biomoléculas do embrião e dos exossomos secretados no meio de cultivo nos dias 3 e 7 do desenvolvimento embrionário. 0 objetivo geral deste trabalho foi investigar os efeitos do estresse oxidativo no embrião e nos exossomos do meio de cultivo da PIVE. Com o objetivo específico de compreender como a alta tensão de oxigênio afeta os embriões consequentemente reduzindo as taxas de prenhes, este estudo se propôs analisar a via de sinalização ERBB, descrita como uma via de interação materno-embrionária. Apesar do miR-199a-5p, descrito como possível regulador dos gene alvo ERBB2 e ERBB3, ter apresentado maior expressão nos embriões cultivados em alta tensão, os transcritos ERBB2 e ERBB3 e a proteína ERBB2 não apresentaram diferença significativa entre os grupos de alta e baixa tensão de oxigênio. A partir destes resultados não há indicação que o miR-199a-5p atuem como regulador pós-transcricional do ERBB2 para embriões bovinos. Portanto, outros estudos são necessários para compreender como o estresse oxidativo interfere no potencial de implantação do embrião, comprometendo as taxas de gestação de embriões cultivados em alta tensão de oxigênio.

Ao refutar a hipótese de que o miR-199a-5p exerce regulação sobre o gene alvo ERBB2 em bovinos, este estudo explorou a expressão de outros 96 transcritos e 378 miRNAs, buscando estabelecer outras relações que explicassem as desordens nos sistemas de reprogramação epigenética e resposta ao estresse oxidativo nos embriões bovinos produzidos in vitro. Foram encontrados 40 RNAm e 8 miRNAs que apresentaram alterações significativas entre os embriões cultivados em alta e baixa tensão de oxigênio. Além disso, os embriões cultivados em alta tensão de oxigênio também apresentaram altos níveis de metilação do DNA. Esta hipermetilação do DNA foi relacionada com o aumento de expressão de transcritos que promovem a metilação do DNA, como DNMT3 e PAF1. Com relação aos transcritos ligados à resposta ao estresse oxidativo, os RNAm SOD1 e CAT também foram encontrados mais expressos nos embriões cultivados na alta tensão de oxigênio. A análise de bioinformática do enriquecimento de vias pelos miRNAs diferentemente expressos revelou a presença da via de sinalização FOXO, que está associada à resposta ao estresse oxidativo 
mediante a transcrição de enzimas antioxidantes como SOD e CAT. Portanto, tanto a análise dos transcritos como das vias enriquecidas pelos miRNAs levam a uma resposta mediada pelo SOD e pela CAT, destacando a importância destas enzimas no processo de ativação de mecanismos de proteção dos embriões expostos à condição de estresse oxidativo.

Por fim, para compreender o efeito do estresse oxidativo sobre a comunicação celular no microambiente de cultivo in vitro este estudo se propôs a analisar os exossomos isolados do meio de cultivo após 3 dias e 7 dias do desenvolvimento. Os resultados observados confirmaram a hipótese de que o estresse oxidativo altera a concentração de exossomos no meio de cultivo e também modifica a expressão dos miRNAs do seu conteúdo. O miR-210, por exemplo, foi observado mais expressos nos exossomos isolados do meio de cultivo de baixa tensão em D7. Apesar do miR-210 ser considerado uma molécula assinatura da condição de hipóxia, como o ambiente fisiológico uterino apresenta baixa tensão de oxigênio (5 a 7\%) este trabalho considerou o miR-210 como biomarcador não invasivo da condição de normoxia no cultivo in vitro de embriões bovinos. Em conclusão, esse estudo contribuiu com conhecimentos sobre a expressão de miRNAs presentes no embrião e nos exossomos do meio de cultivo durante a produção in vitro de embriões em dois modelos de cultivo, alta tensão de oxigênio, que caracteriza a condição de estresse oxidativo celular, e baixa tensão de oxigênio, que estaria próxima às condições fisiológicas. Outros estudos, no entanto, são necessários para compreender com totalidade a influência da regulação dos miRNAs sobre vias importantes para a interação materno-embrionária, como a via de sinalização ERBB. 


\section{Referências}

AGARWAL, $V$. et al. Predicting effective microRNA target sites in mammalian mRNAs. Elife, v. 4, p. e05005, 2015.

AL-DOSSARY, A. A.; MARTIN-DELEON, P. A. Role of exosomes in the reproductive tract Oviductosomes mediate interactions of oviductal secretion with gametes/early embryo. Frontiers in Bioscience (Landmark edition), v. 21, p. 1278-1285, 2015.

AL-DOSSARY, A. A.; STREHLER, E. E.; MARTIN-DELEON, P. A. Expression and secretion of plasma membrane Ca 2+-ATPase 4a (PMCA4a) during murine estrus: association with oviductal exosomes and uptake in sperm. PloS One, v. 8, n. 11, p. e80181, 2013.

ALMIÑANA, C. Snooping on a private conversation between the oviduct and gametes/embryos. Animal Reproduction, v. 12, n. 3, p. 366-374, 2015.

AMERES, S. L.; MARTINEZ, J.; SCHROEDER, R. Molecular basis for target RNA recognition and cleavage by human RISC. Cell, v. 130, n. 1, p. 101-112, 2007.

AMIN, A. et al. Bovine embryo survival under oxidative-stress conditions is associated with activity od the NRF2-mediated oxidative-stress-response pathway. Molecular Reproduction \& Development, v. 81, p. 497-513, 2014.

APLIN, J. D. Embryo implantation: the molecular mechanism remains elusive. Reproductive Biomedicine Online, v. 13, n. 6, p. 833-839, 2006.

BAECKSTROM, D.; ALFORD D.; TAYLOR-PAPADIMITRIOU, J. Morphogenetic and proliferative responses to heregulin of mammary epithelial cells in vitro are dependent on HER2 and HER3 and differ from the responses to HER2 homodimerisation or hepatocyte growth factor. International Journal of Oncology, v. 16, n. 6, p. 1081-90, 2000.

BARKALINA, N. et al. Extracellular vesicle-mediated delivery of molecular compounds into gametes and embryos: learning from nature. Human Reproduction Update, v. 21, n. 5, p. 627-639, 2015.

BARNES, F. L.; FIRST, N. L. Embryonic transcription in in vitro cultured bovine embryos. Molecular Reproduction and Development, v. 29, n. 2, p. 117-123, 1991.

BARTEL, D. P. MicroRNAs: genomics, biogenesis, mechanism, and function. Cell, v. 116, n. 2, p. 281-297, 2004.

BARTEL, D. P. MicroRNAs: target recognition and regulatory functions. Cell, v. 136, n. 2, p. 215-233, 2009.

BAZER, F. W. Pregnancy recognition signaling mechanisms in ruminants and pigs. Journal of Animal Science and Biotechnology, v. 4, n. 23, p. 1-10, 2013. 
BAZER, F. W. et al. Novel pathways for implantation and establishment and maintenance of pregnancy in mammals. Molecular Human Reproduction, v. 16, n. 3, p. 135-153, 2010.

BETTERIDGE, K. J.; FLECHON, J. E. The anatomy and physiology of pre-attachment bovine embryos. Theriogenology, v. 29, n. 1, p. 155-187, 1988.

BING, Y. Z. et al. Effects of thioredoxin on the preimplantation development of bovine embryos. Theriogenology, v. 59, n. 3, p. 863-873, 2003.

BINISZKIEWICZ, D. et al. Dnmt1 overexpression causes genomic hypermethylation, loss of imprinting, and embryonic lethality. Molecular and Cellular Biology, v. 22, n. 7, p. 21242135, 2002.

BIRD, A. DNA methylation patterns and epigenetic memory. Genes \& Development, v. 16, p. 6-21, 2002.

BONTEKOE, S. et al. Low oxygen concentrations for embryo culture in assisted reproductive technologies. The Cochrane Library, 2012.

BRADDOCK, G. W.; BALDWIN, J. P.; BRADBURY, E. M. Neutron-scattering studies of the structure of chromatin core particles in solution. Biopolymers, v. 20, n. 2, p. 327-343, 1981.

BROWN, N. et al. Embryo-uterine interactions via the neuregulin Family of growth factors during implantation in the mouse. Biology of Reproduction, v. 71, p. 2003-2011, 2004.

CARSON, D. D. et al. Embryo Implantation. Developmental Biology, v. 223, p. 217237, 2000.

CHO, H. S.; LEAHY, D. J. Structure of the extracellular region of HER3 reveals an interdomain tether. Science, v. 297, n. 1095-9203 (Electronic), p. 1330-1333, 2002.

CROCOMO, L. et al. Produção de embriões in vitro: estresse oxidativo e antioxidantes. Veterinária e Zootecnia, v. 19, n. 4, p. 470-479, 2012.

DARNELL JR, J. E.; KERR, I. M.; STARK, G. R. Jak-STAT pathways and transcriptional activation in response to IFNs and other extracellular signaling proteins. Science-AAAS-weekly paper edition-including guide to scientific information, v. 264, n. 5164, p. 1415-1420, 1994.

DE MATOS, D. G.; FURNUS, C. C.; MOSES, D. F. Glutathione synthesis during in vitro maturation of bovine oocytes: role of cumulus cells. Biology of Reproduction, v. 57, n. 6, p. 1420-1425, 1997.

DE MATOS, D. G. et al. Effect of cysteamine on glutathione level and developmental capacity of bovine oocyte matured in vitro. Molecular Reproduction and Development, v. 42, n. 4, p. 432-436, 1995. 
DE MATOS, D. G. et al. Stimulation of Glutathione Synthesis of In Vitro Matured Bovine Oocytes and-ItsEffect on Embryo Development and Freezability. Molecular Reproduction and Development, v. 45, p. 451-457, 1996.

DEATON, A. M.; BIRD, A. CpG islands and the regulation of transcription. Genes \& Development, v. 25, n. 10, p. 1010-1022, 2011.

DING, L. et al. A genome-scale RNAi screen for Oct4 modulators defines a role of the Paf1 complex for embryonic stem cell identity. Cell stem cell, v. 4, n. 5, p. 403-415, 2009.

DOWNS, S. M.; DOW, M. P. Hypoxanthine-maintained two-cell block in mouse embryos: dependence on glucose and effect of hypoxanthine phosphoribosyltransferase inhibitors. Biology of Reproduction, v. 44, n. 6, p. 1025-1039, 1991.

DUMOULIN, J. C. M. et al. Effect of oxygen concentration on human in-vitro fertilization and embryo culture. Human Reproduction, v. 14, n. 2, p. 465-469, 1999.

EPPIG, J. J. Oocyte control of ovarian follicular development and function in mammals. Reproduction, v. 122, n. 6, p. 829-838, 2001.

FABBRI, M. et al. MicroRNA-29 family reverts aberrant methylation in lung cancer by targeting DNA methyltransferases $3 \mathrm{~A}$ and 3B. Proceedings of the National Academy of Sciences, v. 104, n. 40, p. 15805-15810, 2007.

FISCHER, B.; BAVISTER, B. D. Oxygen tension in the oviduct and uterus of rhesus monkeys, hamsters and rabbits. Journal of Reproduction and Fertility, v. 99, n. 2, p. 673-679, 1993.

FOCK, V. et al. Trophoblast subtype-specific EGFR/ERBB4 expression correlates with cell cycle progression and hyperplasia in complete hydatidiform moles. Human Reproduction, v. 30, n. 4, p. 789-799, 2015.

FORDE, N.; LONERGAN, P. Transcriptomic analysis of the bovine endometrium: What is required to establish uterine receptivity to implantation in cattle? Journal of Reproduction and Development, v. 58, n. 2, p. 189-195, 2012.

FRANCO, M. C. et al. Nitration of Hsp90 induces cell death. Proceedings of the National Academy of Sciences, v. 110, n. 12, p. E1102-E1111, 2013.

GARCÍA, P. et al. Genome-wide Screening of Regulators of Catalase Expression ROLE OF A TRANSCRIPTION COMPLEX AND HISTONE AND TRNA MODIFICATION COMPLEXES ON ADAPTATION TO STRESS. Journal of Biological Chemistry, v. 291, n. 2, p. 790-799, 2016.

GASPAR, R. C. et al. Oxygen tension affects histone remodeling of in vitro-produced embryos in a bovine model. Theriogenology, v. 83, n. 9, p. 1408-1415, 2015. 
GASPARRINI, B. et al. Glutathione synthesis during in vitro maturation of buffalo (Bubalus bubalis) oocytes: effects of cysteamine on embryo development. Theriogenology, v. 60, n. 5, p. 943-952, 2003.

GASPARRINI, B. et al. Enrichment of in vitro maturation medium for buffalo (Bubalus bubalis) oocytes with thiol compounds: Effects of cystine on glutathione synthesis and embryo development. Theriogenology, v. 65, p. 275-287, 2006.

GEHRING, M.; REIK, W.; HENIKOFF, S. DNA demethylation by DNA repair. Trends in Genetics, v. 25, n. 2, p. 82-90, 2009.

GRAF, A. et al. Fine mapping of genome activation in bovine embryos by RNA sequencing. Proceedings of the National Academy of Sciences, v. 111, n. 11, p. 4139-4144, 2014.

GREENING, D. W. et al. Human endometrial exosomes contain hormone-specific cargo modulating trophoblast adhesive capacity: insights into endometrial-embryo interactions. Biology of Reproduction, p. 115, 2016.

GRIFFITHS, G. S. et al. Investigating the role of murine epididymosomes and uterosomes in GPI-linked protein transfer to sperm using SPAM1 as a model. Molecular Reproduction and Development, v. 75, n. 11, p. 1627-1636, 2008.

GU, T. P. et al. The role of Tet3 DNA dioxygenase in epigenetic reprogramming by oocytes. Nature, v. 477, n. 7366, p. 606-610, 2011.

GUERIN, P.; EL MOUATASSIM, S.; MENEZO, Y. Oxidative stress and protection against reactive oxygen species in the pre-implantation embryo and its surroundings. Human Reproduction Update, v. 7, n. 2, p. 175-189, 2001.

GUO, $\mathrm{H}$. et al. Mammalian microRNAs predominantly act to decrease target mRNA levels. Nature, v. 466, n. 7308, p. 835-840, 2010.

HA, M.; KIM, V. N. Regulation of microRNA biogenesis. Nature Reviews: Molecular Cell Biology, v. 15, n. 8, p. 509-524, 2014.

HALLIWELL, B.; GUTTERIDGE, J. M. C. Capitulo 7: Reactive species can pose special problems needing special solutions: some examples. In: Free Radicals in Biology and Medicine. Oxford University Press, USA, 2015. p. 354-410.

HARVEY, A. J. The role of oxygen in ruminant preimplantation embryo development and metabolism. Animal Reproduction Science, v. 98, n. 1, p. 113-128, 2007.

HARVEY, A. J. et al. Oxygen-regulated gene expression in bovine blastocysts. Biology of Reproduction, v. 71, n. 4, p. 1108-1119, 2004. 
HARVEY, M. B. et al. Expression of genes encoding antioxidant enzymes in preimplantation mouse and cow embryos and primary bovine oviduct cultures employed for embryo coculture. Biology of Reproduction, v. 53, n. 3, p. 532-540, 1995.

HASLER, J. F. The current status of oocyte recovery, in vitro embryo production. Journal Animal Science, v. 76, n. 3, p. 52-74, 1998.

$H E$, J. et al. Reactive oxygen species regulate ERBB2 and ERBB3 expression via miR-199a/125b and DNA methylation. EMBO Reports, v. 13, n. 12, p. 1116-1122, 2012.

HENIKOFF, S. Nucleosome destabilization in the epigenetic regulation of gene expression. Nature Publishing Group, v. 9, p. 15-26, 2008.

HIRASAWA, R. et al. Maternal and zygotic Dnmt1 are necessary and sufficient for the maintenance of DNA methylation imprints during preimplantation development. Genes \& Development, v. 22, n. 12, p. 1607-1616, 2008.

IORIO, M. et al. MicroRNA signatures in human ovarian cancer. Cancer Research, v. 67, n. 18, p. 8699-8707, 2007.

IQBAL, K. et al. Reprogramming of the paternal genome upon fertilization involves genomewide oxidation of 5-methylcytosine. Proceedings of the National Academy of Sciences, $v$. 108, n. 9, p. 3642-3647, 2011.

ISHIKAWA, T. et al. Design and synthesis of novel human epidermal growth factor receptor 2 (HER2)/epidermal growth factor receptor (EGFR) dual inhibitors bearing a pyrrolo[3,2d]pyrimidine scaffold. Journal of Medicinal Chemistry, v. 54, p. 8030-8050, 2011.

IWAKAWA, H.-O.; TOMARI, Y. Molecular insights into microRNA-mediated translational repression in plants. Molecular Cell, v. 52, n. 4, p. 591-601, 2013.

KING, H. W.; MICHAEL, M. Z.; GLEADLE, J. M. Hypoxic enhancement of exosome release by breast cancer cells. BMC Cancer, v. 12, n. 1, p. 1, 2012.

$\mathrm{KLONISCH}, \mathrm{T}$. et al. Epidermal growth fator-like ligands and erbB genes in the periimplantation rabbit uterus and blastocyst. Biology of Reproduction, v. 64, p. 1835-1844, 2001.

KORNBERG, R. D. Chromatin structure: a repeating unit of histones and DNA. Science, v. 184, n. 4139, p. 868-871, 1974.

KORNBERG, R. D.; LORCH, Y. Twenty-five years of the nucleosome, fundamental particle of the eukaryote chromosome. Cell, v. 98, n. 3, p. 285-294, 1999.

KROGAN, N. J. et al. The Paf1 complex is required for histone H3 methylation by COMPASS and Dot1p: linking transcriptional elongation to histone methylation. Molecular Cell, v. 11, n. 3, p. 721-729, 2003. 
KULSHRESHTHA, R. et al. A microRNA signature of hypoxia. Molecular and Cellular Biology, v. 27, n. 5, p. 1859-1867, 2007.

LEE, Y. M. et al. MicroRNA regulation via DNA methylation during the morula to blastocyst transition in mice. Molecular Human Reproduction, v. 18, n. 4, p. 184-193, 2012.

LI, L. et al. Modulation of gene expression and tumor cell growth by redox modification of STAT3. Cancer Research, v. 70, n. 20, p. 8222-8232, 2010.

LI, L.; SHAW, P. E. A STAT3 dimer formed by inter-chain disulphide bridging during oxidative stress. Biochemical and Biophysical Research Communications, v. 322, n. 3, p. 1005-1011, 2004.

LI, L.; ZHENG, P.; DEAN, J. Maternal control of early mouse development. Development, v. 137, n. 6, p. 859-870, 2010.

LI, W. et al. High oxygen tension increases global methylation in bovine 4-cell embryos and blastocysts but does not affect general retrotransposon expression. Reproduction, Fertility and Development, v. 28, p. 948-956, 2014.

LIU, Q. et al. Inhibition of HSP90 promotes neural stem cell survival from oxidative stress through attenuating NF-kB/p65 activation. Oxidative Medicine and Cellular Longevity, v. 2016, 2016.

LOPERA-VASQUEZ, R. et al. Effect of bovine oviductal extracellular vesicles on embryo development and quality in vitro. Reproduction, v. 153, n. 4, p. 461-470, 2017.

MACABELLI, C. H. et al. Reference gene selection for gene expression analysis of oocytes collected from dairy cattle and buffaloes during winter and summer. PloS One, v. 9, n. 3, p. e93287, 2014.

MACHTINGER, R.; LAURENT, L. C.; BACCARELLI, A. A. Extracellular vesicles: roles in gamete maturation, fertilization and embryo implantation. Human Reproduction Update, v. 22, n. 2, p. dmv055, 2015.

MAJID, S. et al. miRNA-34b inhibits prostate cancer through demethylation, active chromatin modifications, and AKT pathways. Clinical Cancer Research, v. 19, n. 1, p. 73-84, 2013.

MANN, M. R. W.; BARTOLOMEI, M. S. Epigenetic reprogramming in the mammalian embryo: struggle of the clones. Genome Biology, v. 3, n. 2, p. 1, 2002.

MATSUI, M. et al. Early embryonic lethality caused by targeted disruption of the mouse thioredoxin gene. Developmental Biology, v. 178, n. 1, p. 179-185, 1996. 
MAYER, W. et al. Embryogenesis: demethylation of the zygotic paternal genome. Nature, v. 403, n. 6769, p. 501-502, 2000.

MCBRIDE, D. et al. Identification of miRNAs associated with the follicular-luteal.

Reproduction Research, v. 144, p. 221-233, 2012.

MCGEADY, T. A. et al. Capítulo 10: Forms of Implantation and Placentation. In: Veterinary Embryology. Blackwell: Oxford, 2006.

MENEZO, Y. J. R. et al. Oxidative stress and alterations in DNA methylation: two sides of the same coin in reproduction. Reproductive BioMedicine Online, v. 33, n. 6, p. 668-683, 2016.

MIORANZA, A. Estudo in silico de elementos regulatórios do genoma e análise do padrão de metilação no DNA de embriões bovinos produzidos por fertilização in vitro e clonagem. 2014, 39-67 f. Tese (Doutorado) Faculdade de Medicina de Ribeirão Preto, Universidade de São Paulo, Ribeirão Preto, 2014.

MITTELBRUNN, M. et al. Unidirectional transfer of microRNA-loaded exosomes from T cells to antigen-presenting cells. Nature Communications, v. 2, p. 282, 2011.

MORALES, $\mathrm{H}$. et al. Pyruvate prevents peroxide-induced injury of in vitro preimplantation bovine embryos. Molecular Reproduction and Development, v. 52, n. 2, p. 149-157, 1999.

NAGY, P. et al. Lipid rafts and the local density of ErbB proteins influence the biological role of homo- and heteroassociations of ErbB2. Journal of Cell Science, v. 115, n. 22, p. 42514262, 2002. Disponível em: < http://jcs.biologists.org/content/115/22/4251.abstract >. Acesso em: 21 nov. 2016.

NASR-ESFAHANI, M. M.; JOHNSON, M. H. The origin of reactive oxygen species in mouse embryos cultured in vitro. Development, v. 113, n. 2, p. 551-560, 1991.

NEGRO, A.; BRAR, B. K. Essential Roles of Her2/erbB2 in Cardiac Developmentand Function. Recent Progress in Hormone Research, v. 59, p. 1-12, 2004.

NG, Y. H. et al. Endometrial exosomes/microvesicles in the uterine microenvironment: a new paradigm for embryo-endometrial cross talk at implantation. PloS One, v. 8, n. 3, p. e58502, 2013.

NGUYEN, C. T. et al. The PAF1 complex component Leo1 is essential for cardiac and neural crest development in zebrafish. Developmental Biology, v. 341, n. 1, p. 167-175, 2010.

OKADA, Y.; YAMAGUCHI, K. Epigenetic modifications and reprogramming in paternal pronucleus: sperm, preimplantation embryo, and beyond. Cellular and Molecular Life Sciences, p. 1-11, 2017.

OKANO, M. et al. DNA methyltransferases Dnmt3a and Dnmt3b are essential for de novo methylation and mammalian development. Cell, v. 99, n. 3, p. 247-257, 1999. 
OKANO, M.; XIE, S.; LI, E. Cloning and characterization of a family of novel mammalian DNA (cytosine-5) methyltransferases. Nature Genetics, v. 19, n. 3, p. 219-220, 1998.

ONO, M.; KUWANO, M. Molecular Mechanisms of epidermal growth fator receptor (EGFR) activation and response to gefitinib and other EGFR-targeting drugs. Clinical Cancer Research, v. 12, p. 7242-7251, 2006.

PINKAS-KRAMARSKI, R. et al. Diversification of Neu differentiation factor and epidermal growth factor signalling by combinatorial receptor interactions. EMBO Journal, v. 15, n. 10, p. 2452-2467, 1996.

PONTES, J. P. Aspectos aplicados da produção in vitro de embriões Bos indicus. 2009, 126127 f. Tese (Doutorado) - Universidade Estadual de Londrina, Paraná, 2009.

RAPOSO, G.; STOORVOGEL, W. Extracellular vesicles: exosomes, microvesicles, and friends. Journal Cell Biology, v. 200, n. 4, p. 373-383, 2013.

REESE, J. et al. Expression of neu differentiation factor during the periimplantation period in the mouse uterus. Biology of Reproduction, v. 58, n. 3, p. 719-727, 1998.

REIK, W.; DEAN, W.; WALTER, J. Epigenetic Reprogramming in Mammalian Development. Science, v. 293, p. 1089-1093, 2001.

RICARTE-FILHO, J. C. M.; KIMURA, E. T. MicroRNAs: Nova Classe de Reguladores Gênicos Envolvidos na Função Endócrina e Câncer. Arquivos Brasileiros de Endocrinologia \& Metabologia, v. 50, n. 6, p. 1102-1107, 2006.

ROCHA-FRIGONI, N. A. D. S. Estratégias para minimização do estresse oxidativo em sistemas de produção in vitro de embriões bovinos destinados à vitrificação. 2016, 22-41 f. Tese (Doutorado) - Universidade Estadual Paulista, Jaboticabal, 2016.

ROCHA-FRIGONI, N. A. S. et al. Reduced levels of intracellular reactive oxygen species and apoptotic status are not correlated with increases in cryotolerance of bovine embryos produced in vitro in the presence of antioxidants. Reproduction, Fertility and Development, v. 26, n. 6, p. 797-805, 2014.

SAADELDIN, I. M. et al. Improvement of cloned embryos development by co-culturing with parthenotes: a possible role of exosomes/microvesicles for embryos paracrine communication. Cellular Reprogramming (Formerly Cloning and Stem Cells), v. 16, n. 3, p. 223-234, 2014.

SALOMON, C. et al. Hypoxia-induced changes in the bioactivity of cytotrophoblast-derived exosomes. PLoS One, v. 8, n. 11, p. e79636, 2013.

SANTOS, F. et al. Dynamic reprogramming of DNA methylation in the early mouse embryo. Developmental Biology, v. 241, n. 1, p. 172-182, 2002. 
SIRARD, M. A. Factors affecting oocyte and embryo transcriptomes. Reproduction in Domestic Animals, v. 47, n. s4, p. 148-155, 2012.

SPENCER, T. E. et al. Pregnancy recognition and conceptus implantation in domestic ruminants: roles of progesterone, interferons and endogenous retroviruses. Reproduction, Fertility and Development, v. 4, n. 23, p. 1-10, 2007.

STEFFENSEN, K. et al. Protein levels and gene expression of the epidermal growth factor receptors HER1, HER2, HER3 and HER4 in benign and malignant ovarian tumors. International Journal of Oncology, v. 33, n. 1, p. 195-204, 2008.

SUZUKI, $\mathrm{H}$. et al. Epigenetic alteration and microRNA dysregulation in cancer. Frontiers in Genetics, v. 4, n. 258, 2013. Disponível em:

< http://journal.frontiersin.org/article/10.3389/fgene.2013.00258 >. Acesso em: 23 jan. 2017.

TAN, K. et al. Downregulation of miR-199a-5p Disrupts the Developmental Potential of In Vitro-Fertilized Mouse Blastocysts 1. Biology of Reproduction, v. 95, n. 3, p. 54-1, 2016.

THÉRY, C.; OSTROWSKI, M.; SEGURA, E. Membrane vesicles as conveyors of immune responses. Nature Reviews Immunology, v. 9, n. 8, p. 581-593, 2009.

UYSAL, F.; AKKOYUNLU, G.; OZTURK, S. Dynamic expression of DNA methyltransferases (DNMTs) in oocytes and early embryos. Biochimie, v. 116, p. 103-113, 2015.

VALADI, $\mathrm{H}$. et al. Exosome-mediated transfer of mRNAs and microRNAs is a novel mechanism of genetic exchange between cells. Nature Cell Biology, v. 9, n. 6, p. 654-659, 2007.

VANROOSE, G. et al. Structural aspects of the zona pellucida of in vitro-produced bovine embryos: a scanning electron and confocal laser scanning microscopic study. Biology of Reproduction, v. 62, n. 2, p. 463-469, 2000.

VLACHOS, I. S. et al. DIANA-miRPath v3. 0: deciphering microRNA function with experimental support. Nucleic Acids Research, v. 43, n. W1, p. W460-W466, 2015.

WANDINGER, S. K.; RICHTER, K.; BUCHNER, J. The Hsp90 chaperone machinery. Journal of Biological Chemistry, v. 283, n. 27, p. 18473-18477, 2008.

WATANABE, D. et al. Stage-and cell-specific expression of Dnmt3a and Dnmt3b during embryogenesis. Mechanisms of development, v. 118, n. 1, p. 187-190, 2002.

WATANABE, T. et al. Dnm3os, a non-coding RNA, is required for normal growth and skeletal development in mice. Developmental Dynamics, v. 237, p. 3738-3748, 2008. 
WOSSIDLO, M. et al. 5-Hydroxymethylcytosine in the mammalian zygote is linked with epigenetic reprogramming. Nature Communications, v. 2, p. 241, 2011.

WYDOOGHE, E. et al. Autocrine embryotropins revisited: how do embryos communicate with each other in vitro when cultured in groups? Biological Reviews, v. 92, n. 1, p. 1-16, 2015.

XIONG, L. et al. DNA demethylation regulates the expression of miR-210 in neural progenitor cells subjected to hypoxia. FEBS Journal, v. 279, n. 23, p. 4318-4326, 2012.

YAMANAKA, K. I. et al. DNA methylation analysis on satellite I region in blastocysts obtained from somatic cell cloned cattle. Animal Science Journal, v. 82, n. 4, p. 523-530, 2011.

YARDEN, Y.; SLIWKOWSKI, M. X. Untangling the ErbB signalling network. Nature Reviews Molecular Cell Biology, v. 2, n. 2, p. 127-137, 2001. Disponível em: < http://dx.doi.org/10.1038/35052073 >. Acesso em: 22 nov. 2016.

YOON, S. et al. Developmental competence of bovine early embryos depends on the coupled. Biology of Reproduction, v. 90, n. 5, p. 1-10, 2014.

ZHANG, G. et al. Small RNA-mediated DNA (cytosine-5) methyltransferase 1 inhibition leads to aberrant DNA methylation. Nucleic Acids Research, v. 43, n. 12, p. 6112-6124, 2015. 


\section{APÊNDICE A - Tabelas suplementares}

Tabela suplementar S.1. Sequência dos primers forward específicos para o perfil de 378 miRNAs e 3 endógenos $(*)$ presentes na placa de amplificação.

\begin{tabular}{|c|c|c|c|}
\hline miRNA & Sequencia & miRNA & Sequencia \\
\hline bta-let-7a-3p & CTATACAATCTACTGTCTTTC & bta-miR-302d & TAAGTGCTTCCATGTTTTAGT \\
\hline bta-let-7a-5p & TGAGGTAGTAGGTTGTATAGTT & bta-miR-3064 & TTGCCACACTGCAACACCTTACA \\
\hline bta-let-7b & TGAGGTAGTAGGTTGTGTGGTT & bta-miR-30a-5p & TGTAAACATCCTCGACTGGAAGCT \\
\hline bta-let-7c & TGAGGTAGTAGGTTGTATGGTT & bta-miR-30b-3p & CTGGGAGGTGGATGTTTACTT \\
\hline bta-let-7d & AGAGGTAGTAGGTTGCATAGTT & bta-miR-30b-5p & TGTAAACATCCTACACTCAGCT \\
\hline bta-let-7e & TGAGGTAGGAGGTTGTATAGT & bta-miR-30c & TGTAAACATCCTACACTCTCAGC \\
\hline bta-let-7f & TGAGGTAGTAGATTGTATAGTT & bta-miR-30d & TGTAAACATCCCCGACTGGAAGCT \\
\hline bta-let-7g & TGAGGTAGTAGTTTGTACAGTT & bta-miR-30e-5p & TGTAAACATCCTTGACTGGAAGCT \\
\hline bta-let-7i & TGAGGTAGTAGTTTGTGCTGTT & bta-miR-30f & TGTAAACACCCTACACTCTCAGCT \\
\hline bta-miR-1 & TGGAATGTAAAGAAGTATGTAT & bta-miR-31 & AGGCAAGATGCTGGCATAGCT \\
\hline bta-miR-100 & AACCCGTAGATCCGAACTTGTG & bta-miR-32 & TATTGCACATGACTAAGTTGCAT \\
\hline bta-miR-101 & TACAGTACTGTGATAACTGAA & bta-miR-320a & AAAAGCTGGGTTGAGAGGGCGA \\
\hline bta-miR-103 & AGCAGCATTGTACAGGGCTATGA & bta-miR-320b & AGCTGGGTTGAGAGGGTGGT \\
\hline bta-miR-105a & TCAAATGCTCAGACTCCTGTGGT & bta-miR-323 & GCACATTACACGGTCGACCTCT \\
\hline bta-miR-105b & TCAAATGCTCAGACTCCTTGGT & bta-miR-324 & CGCATCCCCTAGGGCATTGGTGT \\
\hline bta-miR-106a & AAAAGTGCTTACAGTGCAGGTA & bta-miR-326 & СCTCTGGGCCCTTCCTCCAG \\
\hline bta-miR-106b & TAAAGTGCTGACAGTGCAGAT & bta-miR-328 & CTGGCCCTCTCTGCCCTTCCGT \\
\hline bta-miR-107 & AGCAGCATTGTACAGGGCTATC & bta-miR-329a & AACACACCTGGTTAACCTTTTT \\
\hline bta-miR-10a & TACCCTGTAGATCCGAATTTGTG & bta-miR-329b & AGAGGTTTTCTGGGTTTCTGTTT \\
\hline bta-miR-10b & TACCCTGTAGAACCGAATTTGTG & bta-miR-330 & GCAAAGCACACGGCCTGCAGAGA \\
\hline bta-miR-1179 & AAGCATTCTTTCATTGGTTGG & bta-miR-331-3p & GCCCCTGGGCCTATCCTAGAA \\
\hline bta-miR-1185 & AGAGGATACCCTTTGTATGTT & bta-miR-331-5p & TCTAGGTATGGTCCCAGG \\
\hline bta-miR-1193 & TAGGTCACCCGTTTGACTATC & bta-miR-335 & TCAAGAGCAATAACGAAAAATGT \\
\hline bta-miR-1197 & TAGGACACATGGTCTACTTCT & bta-miR-338 & TCCAGCATCAGTGATTTTGTTGA \\
\hline bta-miR-122 & TGGAGTGTGACAATGGTGTTTG & bta-miR-339a & TCCCTGTCCTCCAGGAGCTCAC \\
\hline bta-miR-122 & TGGAGTGTGACAATGGTGTTTG & bta-miR-339b & TCCCTGTCCTCCAGGAGCTC \\
\hline bta-miR-1224 & GTGAGGACTCGGGAGGTGGAG & bta-miR-33a & GTGCATTGTAGTTGCATTGCA \\
\hline bta-miR-1225-3p & CCGAGCCCCTGTGCCGCCCCCAG & bta-miR-33b & GTGCATTGCTGTTGCATTGC \\
\hline bta-miR-1246 & AATGGATTTTTTGGAGCAGG & bta-miR-340 & TCCGTCTCAGTTACTTTATAGCC \\
\hline bta-miR-1247-3p & CGGGAACGTCGGGACTGGAGC & bta-miR-342 & TCTCACACAGAAATCGCACCCATCT \\
\hline bta-miR-1247-5p & ACCCGTCCCGTGCGTCCCCGGA & bta-miR-345-3p & CCTGAACTAGGGGTCTGGAG \\
\hline bta-miR-1248 & ACCTTCTTGTATAAGCACTGTGCTAAA & bta-miR-345-5p & GCTGACTCCTAGTCCAGTGCT \\
\hline bta-miR-1249 & ACGCCCTTCCCССССТTCTTCA & bta-miR-346 & TGTCTGCCCGCATGCCTGCCTCT \\
\hline bta-miR-124a & TAAGGCACGCGGTGAATGCCAAG & bta-miR-34a & TGGCAGTGTCTTAGCTGGTTGT \\
\hline bta-miR-124b & TAAGGCACGCGGTGAATGCCAAG & bta-miR-34b & AGGCAGTGTAATTAGCTGATTG \\
\hline bta-miR-125a & TCCCTGAGACCCTTTAACCTGTG & bta-miR-34c & AGGCAGTGTAGTTAGCTGATTG \\
\hline bta-miR-125b & TCCCTGAGACCCTAACTTGTGA & bta-miR-361 & TTATCAGAATCTCCAGGGGTAC \\
\hline
\end{tabular}


bta-miR-1260b

bta-miR-126-3p

bta-miR-126-5p

bta-miR-127

bta-miR-1271

bta-miR-1277

bta-miR-128

bta-miR-1281

bta-miR-1282

bta-miR-1284

bta-miR-1287

bta-miR-129

bta-miR-1291

bta-miR-129-3p

bta-miR-129-5p

bta-miR-1296

bta-miR-1298

bta-miR-1301

bta-miR-1306

bta-miR-1307

bta-miR-130a

bta-miR-130b

bta-miR-132

bta-miR-133a

bta-miR-133b

bta-miR-133c

bta-miR-134

bta-miR-1343-3p

bta-miR-1343-5p

bta-miR-135a

bta-miR-135b

bta-miR-136

bta-miR-137

bta-miR-138

bta-miR-1388-3p

bta-miR-139

bta-miR-140

bta-miR-141

bta-miR-142-3p

bta-miR-142-5p

bta-miR-143

bta-miR-144

bta-miR-145

bta-miR-146a
ATCCCACCACTGCCACCA

CGTACCGTGAGTAATAATGCG

CATTATTACTTTTGGTACGCG

TCGGATCCGTCTGAGCTTGGCT

CTTGGCACCTAGTAAGTACTCA

TACGTAGATATATATGTATTTT

TCACAGTGAACCGGTCTCTTT

TCGCCTCCTCCTCTCCC

TCGTTTGCCTTTTTCTGCTT

TCTGCACAGACCCTGGCTTTTC

TGCTGGATCAGTGGTTTGAGTC

CTTTTTGCGGTCTGGGCTTGCT

TGGCCCTGACTGAAGACCTGCAGT

AAGCCCTTACCCCAAAAAGCAT

CTTTTTGCGGTCTGGGCTTGCT

TTAGGGCCCTGGCTCCATCTCC

TTCATTCGGCTGTCCAGATGTA

TTGCAGCTGCCTAGGAGTGATTTC

CCACCTCCCCTGCAAACGTCC

ACTCGGCGTGGCGTCGGTCGTG

CAGTGCAATGTTAAAAGGGCAT

CAGTGCAATGATGAAAGGGCAT

TAACAGTCTACAGCCATGGTCG

TTTGGTCCCCTTCAACCAGCTG

TTTGGTCCCCTTCAACCAGCTA

ATTTGGTTCCATTTTACCAGC

TGTGACTGGTTGACCAGAGTGG

CTCCTGGGGCCCGCACTCTC

TGGGGAGCGGCCCCCGGGCGGG

TATGGCTTTTTATTCCTATGTGA

TATGGCTTTTCATTCCTATGTGA

ACTCCATTTGTTTTGATGATGGA

TTATTGCTTAAGAATACGCGTAG

AGCTGGTGTTGTGAATCAGGCCG

ATCTCAGGTTTGTCAGCCCGCA

TCTACAGTGCACGTGTCTCCAGT

TACCACAGGGTAGAACCACGGA

TAACACTGTCTGGTAAAGATGG

AGTGTTTCCTACTTTATGGATG

CATAAAGTAGAAAGCACTAC

TGAGATGAAGCACTGTAGCTCG

TACAGTATAGATGATGTACTAG

GTCCAGTTTTCCCAGGAATCCCT

TGAGAACTGAATTCCATAGGTTGT
bta-miR-362-3p

bta-miR-362-5p

bta-miR-363

bta-miR-365-3p

bta-miR-365-5p

bta-miR-367

bta-miR-369-3p

bta-miR-369-5p

bta-miR-370

bta-miR-371

bta-miR-374a

bta-miR-374b

bta-miR-375

bta-miR-376a

bta-miR-376b

bta-miR-376c

bta-miR-376d

bta-miR-376e

bta-miR-377

bta-miR-378

bta-miR-378b

bta-miR-378c

bta-miR-378d

bta-miR-379

bta-miR-380-3p

bta-miR-380-5p

bta-miR-381

bta-miR-382

bta-miR-383

bta-miR-409a

bta-miR-409b

bta-miR-410

bta-miR-411a

bta-miR-411b

bta-miR-411c-3p

bta-miR-411c-5p

bta-miR-412

bta-miR-421

bta-miR-423-3p

bta-miR-423-5p

bta-miR-424-3p

bta-miR-424-5p

bta-miR-425-3p

bta-miR-425-5p
AACACACCTATTCAAGGATTC

AATCCTTGGAACCTAGGTGTGAGT

ATTGCACGGTATCCATCTGCG

TAATGCCCCTAAAAATCCTTAT

AGGGACTTTTGGGGGCAGATGTG

GAATTGCACTTTAGCAATGGTGA

AATAATACATGGTTGATCTTT

ATCGACCGTGTTATATTCGC

GCCTGCTGGGGTGGAACCTGGT

AAGTGCCGCCATGTTTTGAGTGT

TTATAATACAACCTGATAAGTG

ATATAATACAACCTGCTAAGTG

TTTTGTTCGTTCGGCTCGCGTGA

ATCATAGAGGAAAATCCACGT

ATCATAGAGGAAAATCCATGTT

GTGGATATTCCTTCTATGTTTA

ATCATAGAGGAAAATCCACAT

AACATAGAGGAAAATCCACATT

ATCACACAAAGGCAACTTTTGT

ACTGGACTTGGAGTCAGAAGGC

ACTTGACTTGGAGTCAGAAGGC

ACTGGACTTGGAGTCAGAAGT

CTGGACTTGGAGTCAGAAGACC

TGGTAGACTATGGAACGTAGG

TATGTAATGTGGTCCACGTCT

TGGTTGACCATAGAACATGCGC

TATACAAGGGCAAGCTCTCTGT

GAAGTTGTTCGTGGTGGATTCG

AGATCAGAAGGTGATTGTGGCT

AGGTTACCCGAGCAACTTTGCAT

GGGGTTCACCGAGCAACATTC

AATATAACACAGATGGCCTGT

ATAGTAGACCGTATAGCGTACG

TGGTCGACCATAAAACGTACGT

TGTATGTCAACTGATCCACAGT

GGTTGATCAGAGAACATACATT

ACTTCACCTGGTCCACTAGCTGT

ATCAACAGACATTAATTGGGCGC

AAGCTCGGTCTGAGGCCCCTCAGT

TGAGGGGCAGAGAGCGAGACTTT

CAAAACGTGAGGCGCTGCTAT

CAGCAGCAATTCATGTTTTGA

ATCGGGAATGTCGTGTCCGCCC

ATGACACGATCACTCCCGTTGA 
bta-miR-146b

bta-miR-147

bta-miR-148a

bta-miR-148b

bta-miR-149-3p

bta-miR-149-5p

bta-miR-150

bta-miR-151-3p

bta-miR-151-5p

bta-miR-152

bta-miR-153

bta-miR-154a

bta-miR-154b

bta-miR-154c

bta-miR-155

bta-miR-15a

bta-miR-15b

bta-miR-16a

bta-miR-16b

bta-miR-17-3p

bta-miR-17-5p

bta-miR-181a

bta-miR-181b

bta-miR-181c

bta-miR-181d

bta-miR-182

bta-miR-183

bta-miR-184

bta-miR-185

bta-miR-186

bta-miR-187

bta-miR-188

bta-miR-18a

bta-miR-18b

bta-miR-190a

bta-miR-190b

bta-miR-191

bta-miR-192

bta-miR-193a

bta-miR-193a-3p

bta-miR-193a-5p

bta-miR-193b

bta-miR-194

bta-miR-195
TGAGAACTGAATTCCATAGGCTGT

GTGTGCGGAAATGCTTCTGCTA

TCAGTGCACTACAGAACTTTGT

TCAGTGCATCACAGAACTTTGT

GAGGGAGGGACGGGGGCTGTGC

TCTGGCTCCGTGTCTTCACTCCC

TCTCCCAACCCTTGTACCAGTGT

CTAGACTGAAGCTCCTTGAGG

TCGAGGAGCTCACAGTCTAGT

TCAGTGCATGACAGAACTTGGG

TTGCATAGTCACAAAAGTGATC

TAGGTTATCCGTGTAGCCTTCG

AGAGGTCTTCCATGGTGCATTCG

AGATATTGCACGGTTGATCTCT

TTAATGCTAATCGTGATAGGGGT

TAGCAGCACATAATGGTTTGT

TAGCAGCACATCATGGTTTACA

TAGCAGCACGTAAATATTGGTG

TAGCAGCACGTAAATATTGGC

ACTGCAGTGAAGGCACTTGT

CAAAGTGCTTACAGTGCAGGTAGT

AACATTCAACGCTGTCGGTGAGTT

AACATTCATTGCTGTCGGTGGGTT

AACATTCAACCTGTCGGTGAGTTT

AACATTCATTGTTGTCGGTGGGT

TTTGGCAATGGTAGAACTCACACT

TATGGCACTGGTAGAATTCACTG

TGGACGGAGAACTGATAAGGGT

TGGAGAGAAAGGCAGTTCCTGA

CAAAGAATTCTCCTTTTTGGGCT

TCGTGTCTTGTGTTGCAGCCGG

CATCCCTTGCATGGTGGAGGGT

TAAGGTGCATCTAGTGCAGATA

TAAGGTGCATCTAGTGCAGTTA

TGATATGTTTGATATATTAGGT

TGATATGTTTGATATTGGGTT

CAACGGAATCCCAAAAGCAGCTG

CTGACCTATGAATTGACAGCCAG

GGGACTTTGTAGGCCAGTT

AACTGGCCTACAAAGTCCCAGT

TGGGTCTTTGCGGGCGAGATGA

AACTGGCCCACAAAGTCCCGCTTT

TGTAACAGCAACTCCATGTGGA

TAGCAGCACAGAAATATTGGCA
bta-miR-429

bta-miR-431

bta-miR-432

bta-miR-433

bta-miR-448

bta-miR-449a

bta-miR-449b

bta-miR-449c

bta-miR-449d

bta-miR-450a

bta-miR-450b

bta-miR-451

bta-miR-452

bta-miR-4523

bta-miR-453

bta-miR-454

bta-miR-455-3p

bta-miR-455-5p

bta-miR-483

bta-miR-484

bta-miR-485

bta-miR-486

bta-miR-487a

bta-miR-487b

bta-miR-488

bta-miR-489

bta-miR-490

bta-miR-491

bta-miR-493

bta-miR-494

bta-miR-495

bta-miR-496

bta-miR-497

bta-miR-499

bta-miR-500

bta-miR-502a

bta-miR-502b

bta-miR-503-3p

bta-miR-503-5p

bta-miR-504

bta-miR-505

bta-miR-532

bta-miR-539

bta-miR-541
TAATACTGTCTGGTAATGCCGT TGTCTTGCAGGCCGTCATGCAGG TCTTGGAGTAGGTCATTGGGTGG ATCATGATGGGCTCCTCGGTGT TTGCATATGTAGGATGTCCCAT TGGCAGTGTATTGTTAGCTGGT AGGCAGTGTATTGTTAGCTGGC AGGCAGTGCATCTCTAGCTGG GAAGGCTGTGTGCTGTGGAG TTTTGCGATGTGTTCCTAATAT TTTTGCAATATGTTCCTGAATA AAACCGTTACCATTACTGAGTTT TGTTTGCAGAGGAAACTGAGAC GACCGAGAGGGCCTCGGCTGT AGGTTGTCCGTGGTGAGTTCGCA TAGTGCAATATTGCTTATAGGGT GCAGTCCATGGGCATATACACT TATGTGCCTTTGGACTACATC TCACTCCTCTCCTCCCGTCTT TCAGGCTCAGTCCCCTCCCGAT AGAGGCTGGCCGTGATGAATTCG TCCTGTACTGAGCTGCCCCGAG AATCATACAGGGACATCCAGT AATCGTACAGGGTCATCCACTT TTGAAAGGCTGTTTCTTGGTC GTGACATCACATATATGGCGAC CAACCTGGAGGACTCCATGCTG AGTGGGGAACCCTTCCATGAGG TGAAGGTCTACTGTGTGCCAGG TGAAACATACACGGGAAACCTC AAACAAACATGGTGCACTTCTT TGAGTATTACATGGCCAATCTC CAGCAGCACACTGTGGTTTGTA TTAAGACTTGCAGTGATGTTT TAATCCTTGCTACCTGGGTGAGA AATGCACCTGGGCAAGGATTCA AATCCACCTGGGCAAGGATTC GGAGTATTGTTTCTGCTGCCCGG TAGCAGCGGGAACAGTACTG AGACCCTGGTCTGCACTCTGTC CGTCAACACTTGCTGGTTTCCT CATGCCTTGAGTGTAGGACCGT GGAGAAATTATCCTTGGTGTGT TGGTGGGCACAGAATCCGGCCT 
bta-miR-196a

bta-miR-196b

bta-miR-197

bta-miR-199a-3p

bta-miR-199a-5p

bta-miR-199b

bta-miR-199c

bta-miR-19a

bta-miR-19b

bta-miR-200a

bta-miR-200b

bta-miR-200c

bta-miR-202

bta-miR-204

bta-miR-205

bta-miR-206

bta-miR-208a

bta-miR-208b

bta-miR-20a

bta-miR-20b

bta-miR-210

bta-miR-211

bta-miR-212

bta-miR-21-3p

bta-miR-214

bta-miR-215

bta-miR-21-5p

bta-miR-216a

bta-miR-216b

bta-miR-217

bta-miR-218

bta-miR-219

bta-miR-219-3p

bta-miR-219-5p

bta-miR-221

bta-miR-222

bta-miR-223

bta-miR-22-3p

bta-miR-224

bta-miR-22-5p

bta-miR-23a

bta-miR-23b-3p

bta-miR-23b-5p

bta-miR-24
TAGGTAGTTTCATGTTGTTGGG TAGGTAGTTTCCTGTTGTTGGGA

TTCACCACCTTCTCCACCCAGC

ACAGTAGTCTGCACATTGGTTA

CCCAGTGTTCAGACTACCTGTT

CCCAGTGTTTAGACTATCTGTTC

TACAGTAGTCTGCACATTGG

TGTGCAAATCTATGCAAAACTGA

TGTGCAAATCCATGCAAAACTGA

TAACACTGTCTGGTAACGATGTT

TAATACTGCCTGGTAATGATG

TAATACTGCCGGGTAATGATGGA

TTCCTATGCATATACTTCTTT

TTCCCTTTGTCATCCTATGCCT

TCCTTCATTCCACCGGAGTCTG

TGGAATGTAAGGAAGTGTGTGG

ATAAGACGAGCAAAAAGCTTGT

ATAAGACGAACAAAAGGTTTGT

TAAAGTGCTTATAGTGCAGGTAG

CAAAGTGCTCACAGTGCAGGTA

ACTGTGCGTGTGACAGCGGCTGA

TTCCCTTTGTCATCCTTTGCC

ACCTTGGCTCTAGACTGCTTACT

AACAGCAGTCGATGGGCTGTCT

ACAGCAGGCACAGACAGGCAGT

ATGACCTATGAATTGACAGACA

TAGCTTATCAGACTGATGTTGACT

TAATCTCAGCTGGCAACTGTGA

AAATCTCTGCAGGCAAATGTGA

TACTGCATCAGGAACTGATTGGAT

TTGTGCTTGATCTAACCATGTG

AGAGTTGAGTCTGGACGTCCCG

AGAATTGTGGCTGGACATCTG

TGATTGTCCAAACGCAATTCTT

AGCTACATTGTCTGCTGGGTTT

AGCTACATCTGGCTACTGGGT

TGTCAGTTTGTCAAATACCCCA

AAGCTGCCAGTTGAAGAACTG

CAAGTCACTAGTGGTTCCGTTTA

AGTTCTTCAGTGGCAAGCTTTA

ATCACATTGCCAGGGATTTCCA

ATCACATTGCCAGGGATTACCAC

GGGTTCCTGGCATGCTGATTT

GTGCCTACTGAGCTGATATCAGT
bta-miR-542-5p

bta-miR-543

bta-miR-544a

bta-miR-544b

bta-miR-545-3p

bta-miR-545-5p

bta-miR-551a

bta-miR-551b

bta-miR-562

bta-miR-568

bta-miR-574

bta-miR-582

bta-miR-584

bta-miR-592

bta-miR-599

bta-miR-615

bta-miR-628

bta-miR-631

bta-miR-652

bta-miR-653

bta-miR-654

bta-miR-655

bta-miR-656

bta-miR-658

bta-miR-660

bta-miR-664a

bta-miR-664b

bta-miR-665

bta-miR-669

bta-miR-670

bta-miR-671

bta-miR-677

bta-miR-7

bta-miR-708

bta-miR-744

bta-miR-758

bta-miR-759

bta-miR-760-3p

bta-miR-760-5p

bta-miR-761

bta-miR-763

bta-miR-764

bta-miR-767

bta-miR-769
TCGGGGATCATCATGTCACGAG AAACATTCGCGGTGCACTTCTT ATTCTGCATTTTTTAGCAAGTTC ATTCTGCATTTCTAACAAGTTC ATCAACAAACATTTATTGTGTG TCAGTAAATGTTTATTGGATG GCGACCCAATCTTGGTTTCCA GGCGACCCATACTTGGTTTCAG AAAGCAGCTGTACCATTTAC ATGTATAAATGTATACACAC TGAGTGTGTGTGTGTGAGTGTGTG TTACAGTTGTTCAACCAGTTACT TGGTTTGCCTGGGACTGAG ATTGTGTCAATATGCGATGATGT GTTGTGTCAGTTTATCAAAC GGGGGTCCCCGGTGCTCGGATC ATGCTGACATATTTACTAGAGG AGACCTGGCTTAGACCTCAGC AATGGCGCCACTAGGGTTGTG GTGTTGAAACAATCTCTGTTG TATGTCTGCTGACCATCACCTT ATAATACATGGTTAACCTCTCT AATATTATACAGTCAACCTCT GGCGGAGGGAAGCGGGTCCGTTGGT TACCCATTGCATATCGGAGCTG CAGGCTGGGGTGTGTGTGGATG TATTCATTTATCTCCCAGCCTAC ACCAGTAGGCCGAGGCCCCT TGTGGGTGTGTGCATGTGCGTG TCCCTGAGTATATGTGGTGAA AGGAAGCCCTGGAGGGGCTGGAG CTCACTGATGAGCAGCTTCTGAC TGGAAGACTAGTGATTTTGTTGTT AAGGAGCTTACAATCTAGCTGGG TGCGGGGCTAGGGCTAACAGCA TTTGTGACCTGGTCCACTAACC GCAGACTGCAAACAATTTTGAC CGGCTCTGGGTCTGTGGGGA CCCCTCAGTCCACCAGAGCCCG GCAGCAGGGTGAAACTGACACA CCAGCTGGGAGGAACCAGTGGC GGTGCTCACTCGTCCTTCT TGCACCATGGTTGTCTGAGCATG TGAGACCTCCGGGTTCTGAGCT 


\begin{tabular}{ll|ll} 
bta-miR-24-3p & TGGCTCAGTTCAGCAGGAACAG & bta-miR-873 & GCAGGAACTTGTGAGTCTCCT \\
bta-miR-25 & CATTGCACTTGTCTCGGTCTGA & bta-miR-874 & CTGCCCTGGCCCGAGGGACCGA \\
bta-miR-26a & TTCAAGTAATCCAGGATAGGCT & bta-miR-875 & TATACCTCAGTTTTATCAGGTG \\
bta-miR-26b & TTCAAGTAATTCAGGATAGGTT & bta-miR-876 & TGGATTTCTTTGTGAATCACCA \\
bta-miR-26c & AGCCTATCCTGGATTACTTGAA & bta-miR-877 & GTAGAGGAGATGGCGCAGGG \\
bta-miR-27a-3p & TTCACAGTGGCTAAGTTCCG & bta-miR-885 & TCCATTACACTACCCTGCCTCT \\
bta-miR-27a-5p & AGGGCTTAGCTGCTTGTGAGCA & bta-miR-92a & TATTGCACTTGTCCCGGCCTGT \\
bta-miR-27b & TTCACAGTGGCTAAGTTCTGC & bta-miR-92b & TATTGCACTCGTCCCGGCCTCC \\
bta-miR-28 & AAGGAGCTCACAGTCTATTGAG & bta-miR-93 & CAAAGTGCTGTTCGTGCAGGTA \\
bta-miR-296-3p & GAGGGTTGGGCGGAGGCTTTCC & bta-miR-935 & CCAGTTACCGCTTCCGCTACCGC \\
bta-miR-296-5p & GAGGGCCCCCCCAATCCT & bta-miR-9-3p & ATAAAGCTAGATAACCG \\
bta-miR-299 & TGGTTTACCGTCCCACATACAT & bta-miR-940 & AAGGCTGGGCCCCCGCTCCGC \\
bta-miR-29a & CTAGCACCATCTGAAATCGGTTA & bta-miR-95 & TTCAACGGGTATTTATTGAGCA \\
bta-miR-29b & TAGCACCATTTGAAATCAGTGTT & bta-miR-9-5p & TCTTTGGTTATCTAGCTGTATG \\
bta-miR-29c & TAGCACCATTTGAAATCGGTTA & bta-miR-96 & TTTGGCACTAGCACATTTTTGT \\
bta-miR-29d-3p & TAGCACCATTTGAAATCGATTA & bta-miR-98 & TGAGGTAGTAAGTTGTATTGTT \\
bta-miR-29d-5p & TGACCGATTTCTCCTGGTGTT & bta-miR-99a-3p & CAAGCTCGCTTCTATGGGT \\
bta-miR-29e & TAGCATCATTTGAAATCAGTGTTT & bta-miR-99a-5p & AACCCGTAGATCCGATCTTGT \\
bta-miR-301a & CAGTGCAATAGTATTGTCAAAGCAT & bta-miR-99b & CACCCGTAGAACCGACCTTGCG \\
bta-miR-301b & CAGTGCAATGATATTGTCAAAGCAT & bta-miR-99b* & CACCCGTAGAACCGACCTTGCG \\
bta-miR-302a & AAGTGCTTCCATGTTTTAGTGA & Hm/Ms/Rt T1 snRNA* CGACTGCATAATTTGTGGTAGTGG \\
bta-miR-302b & TAAGTGCTTCCATGTTTTAGTAG & RNT43 snoRNA* & CTTATTGACGGGCGGACAGAAAC \\
bta-miR-302c & TAAGTGCTTCCATGTTTCAGTGG & & \\
\hline
\end{tabular}


Tabela suplementar S.2. Ensaios de microfluído dos 93 transcritos e 3 endógenos $\left({ }^{*}\right)$ avaliados para 8 repetições biológicas de embriões cultivados em alta ou baixa tensão de $\mathrm{O}_{2}$.

\begin{tabular}{|c|c|c|}
\hline Gene & ID (Thermo) & Nome \\
\hline ACACA & Bt03213389_m1 & Acetyl CoA carboxylase \\
\hline ACSL3 & Bt04282138_m1 & Acyl-CoA Synthetase 3 \\
\hline ACSL6 & Bt03231692_m1 & Acyl-CoA Synthetase 6 \\
\hline ACTB* & PA5-16914 & actin, beta \\
\hline AQP3 & Bt03253663_m1 & aquaporin 3 \\
\hline ATF4 & Bt03221057_m1 & Activating transcription factor 4 \\
\hline ATP5L & Bt03210836_g1 & $\begin{array}{c}\text { ATP synthase, } \mathrm{H}+\text { transporting, mitochondrial Fo complex } \\
\text { subunit } \mathrm{E}\end{array}$ \\
\hline BAX & Bt03211777_g1 & BCL2-Associated X Protein \\
\hline $\mathrm{BCL} 2$ & Bt04298952_m1 & B-cell CLL/lymphoma 2 \\
\hline BID & Bt03241255_m1 & BH3 interacting domain death agonist \\
\hline CASP3 & Bt03250954_g1 & caspase 3 , apoptosis-related cysteine peptidase \\
\hline CASP9 & Bt04282453_m1 & Caspase 9, apoptosis-related cysteine peptidase \\
\hline CAT & Bt03228713_m1 & Catalase \\
\hline CCND2 & Bt03249250_m1 & cyclin D2 \\
\hline CDCA8 & Bt03257041_g1 & Cell division cycle associated 8 \\
\hline CDK6 & Bt04311264_m1 & Cyclin-Dependent Kinase 6 \\
\hline $\mathrm{CDX} 2$ & Bt03649157_m1 & Homeobox protein CDX-2 \\
\hline DDIT3 & Bt03251320_g1 & DNA-damage-inducible transcript 3 \\
\hline Dnmt1 & Bt03224737_m1 & DNA (Cytosine-5-)-Methyltransferase 1 \\
\hline Dnmt3A & Bt01027164_m1 & DNA (Cytosine-5-)-Methyltransferase 3A \\
\hline Dnmt3B & Bt03259810_m1 & DNA (Cytosine-5-)-Methyltransferase 3B \\
\hline EGFR & AJT96D7 & Epidermal growth factor - receptor \\
\hline ELF5 & Bt03220307_m1 & E74-like factor 5 (ets domain transcription factor) \\
\hline ELOVL6 & Bt00907566_m1 & ELOVL fatty acid elongase 6 \\
\hline FADS2 & Bt03256255_g1 & Fatty acid desaturase 2 \\
\hline FASN & Bt03210485_m1 & Fatty Acid synthase \\
\hline FOXO3 & Bt03649334_s1 & forkhead box 03 \\
\hline G6PD & Bt03649181_m1 & Glucose 6 phosphate desidrogenase \\
\hline GADD45A & Bt03225650_m1 & growth arrest and DNA-damage-inducible, alpha \\
\hline GAPDH* & Bt03210912_g1 & glyceraldehyde-3-phosphate dehydrogenase \\
\hline GLRX2 & Bt03229700_m1 & glutaredoxin 2 \\
\hline GPX1 & Bt03259217_g1 & Glutathione Peroxidase 1 \\
\hline GPX4 & Bt03259611_m1 & Glutathione peroxidase 4 \\
\hline GSK3A & Bt03273695_m1 & Glycogen Synthase Kinase 3 alpha \\
\hline H19 & Custom TaqMan & Imprinted Maternally Expressed Transcript \\
\hline H1FOO & Bt03228652_g1 & H1 histone family, member $\mathrm{O}$, oocyte-specific \\
\hline $\mathrm{H} 2 \mathrm{AFZ}$ & Bt03216346_g1 & H2A histone family, member $\mathrm{Z}$ \\
\hline H3F3A & Bt03278804_g1 & H3 histone, family $3 \mathrm{~A}$ \\
\hline H3F3B & Bt04319377_g1 & H3 histone, family 3B (H3.3B) \\
\hline HAND1 & Bt04318733_g1 & Heart and neural crest cell derivative 1 \\
\hline HDAC2 & Bt03244871_m1 & histone deacetylase 2 \\
\hline HIF1A & Bt03259341_m1 & Hypoxia inducible factor 1 (transcription factor) \\
\hline HP1 & Bt03246076_m1 & Heterochromatin protein 1 \\
\hline HSF1 & Bt03249686_m1 & Heat Shock Transcription Factor 1 \\
\hline HSP90AA1 & Bt03218068_g1 & Heat Shock Protein 90kDa Alpha \\
\hline HSPA1A & Bt03292670_g1 & heat shock 70kDa protein 1A \\
\hline HSPA5 & Bt03244880_m1 & Glucose-regulated protein, 78kDa \\
\hline
\end{tabular}




\begin{tabular}{|c|c|c|}
\hline HSPD1 & Bt04301470_g1 & Heat Shock $60 \mathrm{kDa}$ protein $1 \mathrm{~A}$ \\
\hline IGF1R & Bt03649217_m1 & Insulin-Like Growth Factor 1 Receptor \\
\hline IMPDH1 & Bt00995384 m1 & IMP (inosine 5'-monophosphate) dehydrogenase 1 \\
\hline IMPDH2 & Bt03226238_g1 & IMP (inosine 5'-monophosphate) dehydrogenase 2 \\
\hline IFNT2 & Bt03210589_g1 & Interferon tau \\
\hline KEAP1 & Bt03817661_m1 & Kelch-like ECH-associated protein 1 \\
\hline LIPE & Bt03253691_m1 & Lipase, hormone-sensitive (HSL) \\
\hline LUM & Bt03211920_m1 & Lumican \\
\hline MAPK1 & Bt03216718_g1 & Mitogen-Activated Protein Kinase \\
\hline MORF4L2 & Bt03270996_m1 & mortality factor 4 like 2 \\
\hline MTIF3 & Bt03231844_m1 & mitochondrial translational initiation factor 3 \\
\hline NANOG & Bt03220541_m1 & Nanog homeobox \\
\hline NFE2L2 & Bt03251880_m1 & Nuclear factor (erythroid-derived 2)-like 2 \\
\hline NFkB2 & Bt03272789_g1 & $\begin{array}{l}\text { Nuclear Factor Of Kappa Light Polypeptide Gene Enhancer In } \\
\text { B-Cells } 2\end{array}$ \\
\hline NOS2 & Bt03249597_m1 & Nitric oxide synthase 2 , inducible \\
\hline NOS3 & Bt03217679_m1 & nitric oxide synthase 3 \\
\hline NR1H3 & Bt03218363_m1 & nuclear receptor subfamily 1 group $\mathrm{H}$ member 3 \\
\hline OTX2 & Bt04316301_g1 & Orthodenticle Homeobox 2 \\
\hline PA2G4 & Bt03211241_g1 & Proliferation-Associated 2G4 \\
\hline PAF1 & Bt03239371_g1 & RNA Polymerase II Associated Factor \\
\hline PPARG & Bt03217547_m1 & peroxisome proliferator-activated receptor gamma \\
\hline PFKP & Bt04316551_m1 & Phosphofructokinase \\
\hline PGK1 & Bt03225854_mH & Phosphoglycerate Kinase 1 \\
\hline POU5F1 & Bt03223846_g1 & POU class 5 homeobox 1 (OCT4) \\
\hline PPARGC1A & Bt01016720_m1 & $\begin{array}{c}\text { peroxisome proliferator-activated receptor gamma, } \\
\text { coactivator } 1 \text { alpha }\end{array}$ \\
\hline PPARA & Bt03220821_m1 & peroxisome proliferator-activated receptor alpha \\
\hline PPIA* & Bt03224617_g1 & Peptidylprolyl Isomerase A \\
\hline PRDX1 & Bt03223684_m1 & Peroxiredoxin-1 \\
\hline PRDX3 & Bt03214402_m1 & peroxiredoxin 3 \\
\hline PRKCD & Bt03224587_g1 & \\
\hline PTGS2/COX2 & Bt03214489_m1 & Prostaglandin-endoperoxide synthase 2 \\
\hline REST & Bt03278318_s1 & RE1-silencing transcription factor \\
\hline SALL4 & Bt04298191_g1 & Spalt-Like Transcription Factor 4 \\
\hline SCD & Bt04307476_m1 & Stearoyl-CoA desaturase \\
\hline SOD1 & Bt03215423_g1 & superoxide dismutase 1 , soluble \\
\hline SOD2 & Bt03244551_m1 & superoxide dismutase 2 , mitochondrial \\
\hline sox2 & Bt03278318_s1 & SRY (sex determining region Y)-box 2 \\
\hline SREBF1 & Bt03276370_m1 & Sterol Regulatory Element Binding Transcription F1 \\
\hline SREBF2 & Bt04283467_m1 & Sterol Regulatory Element Binding Transcription F2 \\
\hline STAT3 & Bt03259871_g1 & Signal Transducer And Activator Of Transcription 3 \\
\hline TFAM & Bt03260078_m1 & Transcription Factor A, Mitochondrial \\
\hline TNFRSF21 & Bt03250597_m1 & Tumor necrosis factor receptor superfamily member 21 \\
\hline TNFRSF21 & Bt03250597_m1 & Tumor necrosis factor receptor superfamily member 21 \\
\hline TP53 & Bt03223213_m1 & tumor protein $\mathrm{p} 53$ \\
\hline TXN & Bt03222879_m1 & Thioredoxin \\
\hline TXNRD1 & Bt03215471_m1 & Thioredoxin reductase 1 \\
\hline VEGFA & Bt03213282_m1 & Vascular Endothelial Growth Factor A \\
\hline VNN1 & Bt03220248_m1 & Vanin 1 \\
\hline XBP1 & Bt03227621_g1 & X-Box Binding Protein 1 \\
\hline
\end{tabular}


Tabela suplementar S.3. Lista completa da expressão relativa dos 378 miRNAs para 3 repetições biológicas em blastocistos bovinos cultivados em alta e baixa tensões de oxigênio.

\begin{tabular}{|c|c|c|c|c|}
\hline & \multicolumn{2}{|c|}{ Alto $\mathrm{O}_{2}$} & \multicolumn{2}{|c|}{ Baixo $\mathrm{O}_{2}$} \\
\hline Genes & Média & DP & Média & DP \\
\hline bta-let-7b & \multicolumn{2}{|c|}{ ND } & \multicolumn{2}{|c|}{ ND } \\
\hline bta-let-7c & 0,001029 & 0,000302 & 0,001370 & 0,000198 \\
\hline bta-let-7d & 0,001513 & 0,000134 & 0,001736 & 0,000674 \\
\hline bta-let-7e & 0,001827 & 0,000492 & 0,002007 & 0,000961 \\
\hline bta-let-7f & 0,001068 & 0,000333 & 0,001040 & 0,000204 \\
\hline bta-let-7g & 0,000203 & 0,000061 & 0,000170 & 0,000088 \\
\hline bta-let-7i & \multicolumn{2}{|c|}{ ND } & \multicolumn{2}{|c|}{ ND } \\
\hline bta-miR-100 & \multicolumn{2}{|c|}{ ND } & 0,000094 & 0,000028 \\
\hline bta-miR-101 & 0,003075 & 0,000125 & 0,001997 & 0,000718 \\
\hline bta-miR-103 & 0,009131 & 0,002349 & 0,010468 & 0,003065 \\
\hline bta-miR-105a & 0,000386 & 0,000186 & \multicolumn{2}{|c|}{ ND } \\
\hline bta-miR-105b & 0,001252 & 0,000236 & 0,001404 & 0,000180 \\
\hline bta-miR-106a & 0,036482 & 0,010689 & 0,037450 & 0,009418 \\
\hline bta-miR-106b & 0,012447 & 0,005078 & 0,015084 & 0,008924 \\
\hline bta-miR-107 & 0,000544 & 0,000162 & 0,000541 & 0,000121 \\
\hline bta-miR-10a & 0,001593 & 0,000251 & 0,001108 & 0,000254 \\
\hline bta-miR-10b & 0,001761 & 0,000359 & 0,002053 & 0,000430 \\
\hline bta-miR-1185 & \multicolumn{2}{|c|}{ ND } & \multicolumn{2}{|c|}{ ND } \\
\hline bta-miR-1193 & \multicolumn{2}{|c|}{ ND } & \multicolumn{2}{|c|}{ ND } \\
\hline bta-miR-1197 & \multicolumn{2}{|c|}{ ND } & 0,000057 & 0,000012 \\
\hline bta-miR-122 & 0,000166 & 0,000116 & 0,000150 & 0,000105 \\
\hline bta-miR-122 & 0,000070 & 0,000019 & \multicolumn{2}{|c|}{ ND } \\
\hline bta-miR-1224 & 0,251972 & 0,037428 & 0,271867 & 0,041329 \\
\hline bta-miR-1225-3p & 0,078412 & 0,006785 & \multicolumn{2}{|c|}{ ND } \\
\hline bta-miR-1246 & 21,030835 & 1,014413 & 21,230900 & 1,981096 \\
\hline bta-miR-1247-3p & 0,014039 & 0,003877 & 0,013321 & 0,002578 \\
\hline bta-miR-1247-5p & 0,069030 & 0,010843 & 0,082851 & 0,007042 \\
\hline bta-miR-1248 & 0,163652 & 0,010807 & 0,148606 & 0,018073 \\
\hline bta-miR-1249 & 0,000911 & 0,000083 & 0,000993 & 0,000088 \\
\hline bta-miR-124a & 0,000683 & 0,000332 & \multicolumn{2}{|c|}{ ND } \\
\hline bta-miR-124b & 0,000722 & 0,000162 & \multicolumn{2}{|c|}{ ND } \\
\hline bta-miR-125a & 0,001893 & 0,000409 & 0,001880 & 0,000438 \\
\hline bta-miR-125b & 0,000515 & 0,000128 & 0,000406 & 0,000141 \\
\hline bta-miR-1260b & $0,599688^{a}$ & 0,020980 & $0,543880^{b}$ & 0,024688 \\
\hline bta-miR-126-3p & \multicolumn{2}{|c|}{ ND } & 0,000092 & 0,000026 \\
\hline bta-miR-126-5p & \multicolumn{2}{|c|}{ ND } & 0,000266 & 0,000312 \\
\hline bta-miR-127 & \multicolumn{2}{|c|}{ ND } & \multicolumn{2}{|c|}{ ND } \\
\hline bta-miR-1271 & 0,005370 & 0,001223 & 0,006043 & 0,001324 \\
\hline bta-miR-128 & 0,000715 & 0,000329 & 0,000742 & 0,000110 \\
\hline
\end{tabular}




\begin{tabular}{|c|c|c|c|c|}
\hline bta-miR-1281 & 0,018695 & 0,006881 & 0,016732 & 0,002583 \\
\hline bta-miR-1282 & \multicolumn{2}{|c|}{ ND } & \multicolumn{2}{|c|}{ ND } \\
\hline bta-miR-1284 & \multicolumn{2}{|c|}{ ND } & 0,000278 & 0,000174 \\
\hline bta-miR-1287 & 0,000173 & 0,000083 & 0,000260 & 0,000179 \\
\hline bta-miR-129 & 0,001982 & 0,000640 & 0,001920 & 0,000717 \\
\hline bta-miR-1291 & 0,033389 & 0,005704 & 0,037435 & 0,001302 \\
\hline bta-miR-129-3p & 0,000391 & 0,000032 & \multicolumn{2}{|c|}{ ND } \\
\hline bta-miR-129-5p & 0,002129 & 0,000717 & \multicolumn{2}{|c|}{ ND } \\
\hline bta-miR-1296 & \multicolumn{2}{|c|}{ ND } & \multicolumn{2}{|c|}{ ND } \\
\hline bta-miR-1298 & \multicolumn{2}{|c|}{ ND } & 0,000141 & 0,000069 \\
\hline bta-miR-1301 & \multicolumn{2}{|c|}{ ND } & 0,000080 & 0,000020 \\
\hline bta-miR-1306 & 0,001085 & 0,000450 & 0,001229 & 0,000208 \\
\hline bta-miR-1307 & 0,071044 & 0,011111 & 0,083743 & 0,012828 \\
\hline bta-miR-130a & 0,000644 & 0,000239 & 0,000623 & 0,000211 \\
\hline bta-miR-130b & 0,023613 & 0,008660 & 0,023976 & 0,007973 \\
\hline bta-miR-132 & 0,000264 & 0,000059 & \multicolumn{2}{|c|}{ ND } \\
\hline bta-miR-133a & \multicolumn{2}{|c|}{ ND } & 0,001396 & 0,000737 \\
\hline bta-miR-133b & \multicolumn{2}{|c|}{ ND } & \multicolumn{2}{|c|}{ ND } \\
\hline bta-miR-133c & \multicolumn{2}{|c|}{ ND } & 0,000127 & 0,000054 \\
\hline bta-miR-134 & \multicolumn{2}{|c|}{ ND } & \multicolumn{2}{|c|}{ ND } \\
\hline bta-miR-1343-3p & 0,015811 & 0,004689 & 0,012024 & 0,004069 \\
\hline bta-miR-1343-5p & 0,145174 & 0,013273 & 0,165255 & 0,029997 \\
\hline bta-miR-135a & 0,000113 & 0,000054 & \multicolumn{2}{|c|}{ ND } \\
\hline bta-miR-135b & \multicolumn{2}{|c|}{ ND } & & \\
\hline bta-miR-136 & \multicolumn{2}{|c|}{ ND } & 0,000134 & 0,000024 \\
\hline bta-miR-137 & \multicolumn{2}{|c|}{ ND } & \multicolumn{2}{|c|}{ ND } \\
\hline bta-miR-138 & 0,007836 & 0,000842 & 0,009144 & 0,001235 \\
\hline bta-miR-1388-3p & 0,003209 & 0,000652 & 0,003526 & 0,001226 \\
\hline bta-miR-139 & 0,000700 & 0,000138 & 0,000470 & 0,000323 \\
\hline bta-miR-140 & $0,000194^{a}$ & 0,000027 & $0,000349^{b}$ & 0,000076 \\
\hline bta-miR-141 & 0,003520 & 0,000966 & 0,002602 & 0,000453 \\
\hline bta-miR-142-5p & \multicolumn{2}{|c|}{ ND } & \multicolumn{2}{|c|}{ ND } \\
\hline bta-miR-143 & 0,002318 & 0,001470 & 0,002417 & 0,001087 \\
\hline bta-miR-145 & \multicolumn{2}{|c|}{ ND } & \multicolumn{2}{|c|}{ ND } \\
\hline bta-miR-146a & & & 0,000169 & 0,000070 \\
\hline bta-miR-146b & 0,000279 & 0,000151 & 0,000338 & 0,000321 \\
\hline bta-miR-147 & & & & \\
\hline bta-miR-148a & 0,010448 & 0,001841 & 0,009647 & 0,001815 \\
\hline bta-miR-148b & 0,009024 & 0,002015 & 0,008337 & 0,001601 \\
\hline bta-miR-149-3p & 0,144476 & 0,029342 & 0,150662 & 0,019330 \\
\hline bta-miR-149-5p & 0,002419 & 0,000338 & & \\
\hline bta-miR-150 & 0,001538 & 0,000694 & 0,001133 & 0,001265 \\
\hline bta-miR-151-3p & 0,006869 & 0,001488 & 0,005736 & 0,000923 \\
\hline bta-miR-151-5p & 0,011920 & 0,002359 & 0,012712 & 0,004945 \\
\hline
\end{tabular}




\begin{tabular}{|c|c|c|c|c|}
\hline bta-miR-152 & \multicolumn{2}{|c|}{ ND } & \multicolumn{2}{|c|}{ ND } \\
\hline bta-miR-153 & \multicolumn{2}{|c|}{ ND } & \multicolumn{2}{|c|}{ ND } \\
\hline bta-miR-154a & 0,000153 & 0,000032 & \multicolumn{2}{|c|}{ ND } \\
\hline bta-miR-154b & 0,000426 & 0,000131 & 0,000244 & 0,000168 \\
\hline bta-miR-154c & 0,000228 & 0,000211 & 0,000163 & 0,000103 \\
\hline bta-miR-155 & $0,000385^{a}$ & 0,000090 & $0,000173^{b}$ & 0,000092 \\
\hline bta-miR-15a & 0,004533 & 0,001036 & 0,003543 & 0,000813 \\
\hline bta-miR-15b & 0,010217 & 0,002214 & 0,009870 & 0,002730 \\
\hline bta-miR-16a & 0,010348 & 0,002776 & 0,009737 & 0,001632 \\
\hline bta-miR-16b & 0,023888 & 0,007464 & 0,024263 & 0,009054 \\
\hline bta-miR-17-3p & 0,001139 & 0,000459 & 0,000782 & 0,000319 \\
\hline bta-miR-17-5p & 0,007152 & 0,002069 & 0,007865 & 0,001707 \\
\hline bta-miR-181a & 0,000081 & 0,000016 & \multicolumn{2}{|c|}{ ND } \\
\hline bta-miR-181b & 0,000267 & 0,000095 & 0,000326 & 0,000199 \\
\hline bta-miR-181c & \multicolumn{2}{|c|}{ ND } & \multicolumn{2}{|c|}{ ND } \\
\hline bta-miR-181d & 0,000344 & 0,000019 & \multicolumn{2}{|c|}{ ND } \\
\hline bta-miR-182 & 0,000388 & 0,000391 & 0,000407 & 0,000112 \\
\hline bta-miR-183 & \multicolumn{2}{|c|}{ ND } & \multicolumn{2}{|c|}{ ND } \\
\hline bta-miR-184 & 0,000313 & 0,000098 & 0,000257 & 0,000148 \\
\hline bta-miR-185 & 0,001184 & 0,000399 & \multicolumn{2}{|c|}{ ND } \\
\hline bta-miR-186 & 0,002278 & 0,000606 & 0,001389 & 0,000540 \\
\hline bta-miR-187 & 0,005016 & 0,000452 & 0,004311 & 0,001734 \\
\hline bta-miR-188 & 0,001606 & 0,000302 & \multicolumn{2}{|c|}{ ND } \\
\hline bta-miR-18a & 0,006899 & 0,001582 & 0,006594 & 0,001286 \\
\hline bta-miR-18b & 0,003117 & 0,001265 & 0,002710 & 0,000423 \\
\hline bta-miR-190a & 0,000603 & 0,000211 & 0,000566 & 0,000143 \\
\hline bta-miR-190b & 0,000090 & 0,000037 & \multicolumn{2}{|c|}{ ND } \\
\hline bta-miR-191 & 0,004533 & 0,001046 & \multicolumn{2}{|c|}{ ND } \\
\hline bta-miR-192 & 0,002348 & 0,000026 & 0,002168 & 0,000621 \\
\hline bta-miR-193a & \multicolumn{2}{|c|}{ ND } & \multicolumn{2}{|c|}{ ND } \\
\hline bta-miR-193a-3p & \multicolumn{2}{|c|}{ ND } & 0,000493 & 0,000166 \\
\hline bta-miR-193a-5p & 0,001682 & 0,000330 & 0,002009 & 0,001247 \\
\hline bta-miR-193b & 0,000111 & 0,000035 & 0,000106 & 0,000052 \\
\hline bta-miR-194 & 0,006437 & 0,001045 & 0,006153 & 0,001935 \\
\hline bta-miR-195 & 0,003523 & 0,001121 & 0,003648 & 0,000589 \\
\hline bta-miR-196a & 0,000899 & 0,000058 & 0,000800 & 0,000242 \\
\hline bta-miR-196b & 0,001103 & 0,000421 & 0,000819 & 0,000448 \\
\hline bta-miR-197 & \multicolumn{2}{|c|}{ ND } & \multicolumn{2}{|c|}{ ND } \\
\hline bta-miR-199a-3p & \multicolumn{2}{|c|}{ ND } & \multicolumn{2}{|c|}{ ND } \\
\hline bta-miR-199a-5p & \multicolumn{2}{|c|}{ ND } & \multicolumn{2}{|c|}{ ND } \\
\hline bta-miR-199b & \multicolumn{2}{|c|}{ ND } & & \\
\hline bta-miR-199c & & & & \\
\hline bta-miR-19a & $0,003829^{a}$ & 0,001135 & $0,001358^{b}$ & 0,000300 \\
\hline bta-miR-19b & 0,003755 & 0,002123 & 0,001641 & 0,000319 \\
\hline
\end{tabular}




\begin{tabular}{|c|c|c|c|c|}
\hline bta-miR-200a & 0,000150 & 0,000071 & \multicolumn{2}{|c|}{ ND } \\
\hline bta-miR-200b & 0,001927 & 0,000406 & 0,002271 & 0,000273 \\
\hline bta-miR-200c & 0,001721 & 0,000496 & 0,002431 & 0,000162 \\
\hline bta-miR-202 & 0,000306 & 0,000221 & 0,000519 & 0,000338 \\
\hline bta-miR-204 & 0,000527 & 0,000300 & 0,000269 & 0,000097 \\
\hline bta-miR-205 & 0,000770 & 0,000372 & 0,000883 & 0,000526 \\
\hline bta-miR-206 & \multicolumn{2}{|c|}{ ND } & 0,000460 & 0,000125 \\
\hline bta-miR-208a & \multicolumn{2}{|c|}{ ND } & 0,000060 & 0,000027 \\
\hline bta-miR-20a & 0,038580 & 0,007451 & 0,036791 & 0,009136 \\
\hline bta-miR-20b & 0,015488 & 0,002515 & 0,015130 & 0,003607 \\
\hline bta-miR-210 & $0,003161^{a}$ & 0,000335 & $0,005046^{b}$ & 0,000839 \\
\hline bta-miR-211 & 0,000616 & 0,000153 & 0,000386 & 0,000200 \\
\hline bta-miR-212 & 0,000082 & 0,000041 & 0,000087 & 0,000048 \\
\hline bta-miR-21-3p & \multicolumn{2}{|c|}{ ND } & \multicolumn{2}{|c|}{ ND } \\
\hline bta-miR-214 & \multicolumn{2}{|c|}{ ND } & 0,002908 & 0,001349 \\
\hline bta-miR-215 & 0,001510 & 0,000014 & 0,001803 & 0,000901 \\
\hline bta-miR-21-5p & 0,001432 & 0,000498 & 0,001797 & 0,000391 \\
\hline bta-miR-216a & 0,000682 & 0,000038 & \\
\hline bta-miR-216b & \multicolumn{2}{|c|}{ ND } & & \\
\hline bta-miR-217 & \multicolumn{2}{|c|}{ ND } & \multicolumn{2}{|c|}{ ND } \\
\hline bta-miR-218 & \multicolumn{2}{|c|}{ ND } & \multicolumn{2}{|c|}{ ND } \\
\hline bta-miR-219 & \multicolumn{2}{|c|}{ ND } & \multicolumn{2}{|c|}{ ND } \\
\hline bta-miR-219-3p & 0,000972 & 0,000353 & \multicolumn{2}{|c|}{ ND } \\
\hline bta-miR-219-5p & 0,000200 & 0,000097 & \multicolumn{2}{|c|}{ ND } \\
\hline bta-miR-221 & 0,005569 & 0,001061 & 0,004894 & 0,001629 \\
\hline bta-miR-222 & 0,005099 & 0,001475 & 0,004718 & 0,000636 \\
\hline bta-miR-223 & \multicolumn{2}{|c|}{ ND } & 0,000087 & 0,000045 \\
\hline bta-miR-22-5p & $0,000670^{a}$ & 0,000165 & $0,001015^{b}$ & 0,000123 \\
\hline bta-miR-224 & \multicolumn{2}{|c|}{ ND } & \multicolumn{2}{|c|}{ ND } \\
\hline bta-miR-23a & 0,003998 & 0,000482 & 0,003722 & 0,000645 \\
\hline bta-miR-23b-3p & 0,002839 & 0,000361 & 0,002415 & 0,000920 \\
\hline bta-miR-23b-5p & 0,000422 & 0,000139 & 0,000290 & 0,000053 \\
\hline bta-miR-24 & 0,000270 & 0,000105 & 0,000304 & 0,000079 \\
\hline bta-miR-24-3p & 0,003921 & 0,000645 & 0,003192 & 0,000460 \\
\hline bta-miR-25 & 0,013192 & 0,004264 & 0,011789 & 0,002812 \\
\hline bta-miR-26a & 0,014912 & 0,003067 & 0,015226 & 0,002445 \\
\hline bta-miR-26b & 0,003041 & 0,000039 & 0,003268 & 0,001262 \\
\hline bta-miR-27a-3p & 0,001404 & 0,000268 & 0,001334 & 0,000144 \\
\hline bta-miR-27a-5p & \multicolumn{2}{|c|}{ ND } & 0,000344 & 0,000211 \\
\hline bta-miR-27b & 0,003876 & 0,001031 & 0,003801 & 0,000661 \\
\hline bta-miR-28 & 0,002217 & 0,000515 & 0,002255 & 0,000061 \\
\hline bta-miR-296-3p & 0,006298 & 0,000691 & 0,005628 & 0,000933 \\
\hline bta-miR-296-5p & \multicolumn{2}{|c|}{ ND } & 0,001666 & 0,000700 \\
\hline bta-miR-299 & \multicolumn{2}{|c|}{ ND } & \multicolumn{2}{|c|}{ ND } \\
\hline
\end{tabular}




\begin{tabular}{|c|c|c|c|c|}
\hline bta-miR-29a & 0,000576 & 0,000129 & 0,000473 & 0,000191 \\
\hline bta-miR-29b & 0,000150 & 0,000029 & 0,000159 & 0,00009 \\
\hline bta-miR-29c & 0,000367 & 0,000086 & 0,000545 & 0,000232 \\
\hline bta-miR-29d-3p & \multicolumn{2}{|c|}{ ND } & \multicolumn{2}{|c|}{ ND } \\
\hline ta-miR-29d-5p & \multicolumn{2}{|c|}{ ND } & \multicolumn{2}{|c|}{ ND } \\
\hline bta-miR-29e & \multicolumn{2}{|c|}{ ND } & \multicolumn{2}{|c|}{ ND } \\
\hline bta-miR-301a & 0,000323 & 0,000214 & 0,000302 & 0,000107 \\
\hline bta-miR-301b & 0,000277 & 0,000134 & 0,000240 & 0,00016 \\
\hline bta-miR-302a & 0,004713 & 0,001732 & 0,004459 & 0,001332 \\
\hline bta-miR-302b & 0,002264 & 0,000327 & 0,002453 & $0,00061 \epsilon$ \\
\hline bta-miR-302c & 0,000906 & 0,000724 & 0,001337 & 0,000262 \\
\hline bta-miR-302d & 0,008904 & 0,002697 & 0,009022 & 0,001068 \\
\hline bta-miR-3064 & \multicolumn{2}{|c|}{ ND } & 0,000222 & 0,000032 \\
\hline bta-miR-30a-5p & 0,012228 & 0,004879 & 0,009701 & $0,00112 \epsilon$ \\
\hline bta-miR-30b-3p & 0,000252 & 0,000112 & 0,000151 & 0,000077 \\
\hline bta-miR-30b-5p & 0,004180 & 0,000988 & 0,003979 & $0,00060 s$ \\
\hline bta-miR-30c & 0,008389 & 0,001915 & 0,007459 & 0,000914 \\
\hline bta-miR-30d & 0,010447 & 0,002462 & 0,009284 & 0,00198 \\
\hline bta-miR-30e-5p & 0,011915 & 0,002550 & 0,009564 & 0,002226 \\
\hline bta-miR-30f & \multicolumn{2}{|c|}{ ND } & 0,004299 & 0,000733 \\
\hline bta-miR-31 & 0,000607 & 0,000095 & 0,000702 & 0,000681 \\
\hline bta-miR-32 & 0,000264 & 0,000115 & \multicolumn{2}{|c|}{ ND } \\
\hline bta-miR-320a & 0,018252 & 0,003437 & 0,019688 & 0,000610 \\
\hline bta-miR-320b & 0,003674 & 0,000610 & 0,003610 & 0,001110 \\
\hline bta-miR-323 & 11,369218 & 2,106507 & 10,306215 & 2,077691 \\
\hline bta-miR-324 & 0,000760 & 0,000190 & 0,000944 & 0,000056 \\
\hline bta-miR-326 & \multicolumn{2}{|c|}{ ND } & 0,002599 & 0,000851 \\
\hline bta-miR-328 & 0,002293 & 0,000746 & \multicolumn{2}{|c|}{ ND } \\
\hline bta-miR-329a & \multicolumn{2}{|c|}{ ND } & \multicolumn{2}{|c|}{ ND } \\
\hline bta-miR-329b & \multicolumn{2}{|c|}{ ND } & 0,000117 & 0,000073 \\
\hline bta-miR-330 & \multicolumn{2}{|c|}{ ND } & 0,001541 & 0,000437 \\
\hline bta-miR-331-3p & 0,000262 & 0,000121 & 0,000090 & 0,000070 \\
\hline bta-miR-331-5p & 0,001479 & 0,000387 & \multicolumn{2}{|c|}{ ND } \\
\hline bta-miR-335 & 0,000094 & 0,000018 & \multicolumn{2}{|c|}{ ND } \\
\hline bta-miR-338 & 0,000398 & 0,000138 & 0,000366 & 0,000245 \\
\hline bta-miR-339a & 0,005527 & 0,000930 & 0,005560 & 0,000745 \\
\hline bta-miR-339b & 0,006959 & 0,000910 & \multicolumn{2}{|c|}{ ND } \\
\hline bta-miR-33a & 0,000255 & 0,000064 & 0,000299 & 0,00019 \\
\hline bta-miR-33b & \multicolumn{2}{|c|}{ ND } & 0,000253 & 0,000205 \\
\hline bta-miR-340 & 0,000220 & 0,000131 & \multicolumn{2}{|c|}{ ND } \\
\hline bta-miR-342 & 0,002242 & 0,000686 & 0,001775 & 0,000447 \\
\hline bta-miR-345-3p & \multicolumn{2}{|c|}{ ND } & 0,001590 & 0,000587 \\
\hline bta-miR-345-5p & 0,001455 & 0,000035 & 0,001509 & 0,00033 \\
\hline bta-miR-346 & 0,020668 & 0,007458 & 0,016558 & 0,002437 \\
\hline
\end{tabular}




\begin{tabular}{|c|c|c|c|c|}
\hline bta-miR-34a & 0,012045 & 0,001922 & 0,011681 & 0,001737 \\
\hline bta-miR-34b & 0,001038 & 0,000365 & 0,000472 & $0,00010 \varepsilon$ \\
\hline bta-miR-34c & $0,000649^{a}$ & 0,000051 & $0,000485^{b}$ & 0,000037 \\
\hline bta-miR-361 & 0,002134 & 0,000218 & 0,001981 & 0,000479 \\
\hline ta-miR-362-3p & 0,000407 & 0,000319 & 0,000360 & 0,000215 \\
\hline bta-miR-362-5p & 0,000612 & 0,000173 & 0,000753 & 0,000125 \\
\hline bta-miR-363 & 0,000230 & 0,000139 & 0,000187 & 0,000071 \\
\hline bta-miR-365-3p & 0,001228 & 0,000362 & 0,001463 & 0,000497 \\
\hline bta-miR-365-5p & 0,003763 & 0,001573 & 0,004112 & 0,002803 \\
\hline bta-miR-367 & 0,000071 & 0,000035 & \multicolumn{2}{|c|}{ ND } \\
\hline bta-miR-369-3p & 0,000341 & 0,000246 & 0,000290 & 0,000171 \\
\hline bta-miR-369-5p & \multicolumn{2}{|c|}{ ND } & 0,000124 & 0,000077 \\
\hline bta-miR-370 & 0,003769 & 0,000281 & 0,003353 & 0,000802 \\
\hline bta-miR-371 & 0,083009 & 0,023344 & 0,061044 & $0,01818 \varepsilon$ \\
\hline bta-miR-374a & 0,001105 & 0,000473 & 0,001606 & 0,00025 \\
\hline bta-miR-374b & 0,001048 & 0,000237 & 0,001457 & 0,00055 \\
\hline bta-miR-375 & 0,000535 & 0,000063 & 0,000712 & 0,000247 \\
\hline bta-miR-376a & \multicolumn{2}{|c|}{ ND } & 0,000247 & 0,00012 \\
\hline bta-miR-376b & 0,000099 & 0,000048 & \multicolumn{2}{|c|}{ ND } \\
\hline bta-miR-376c & 0,000555 & 0,000510 & 0,000467 & 0,000337 \\
\hline bta-miR-376d & 0,000423 & 0,000282 & 0,000166 & 0,000077 \\
\hline bta-miR-376e & 0,000195 & 0,000088 & 0,000173 & 0,000062 \\
\hline bta-miR-377 & 0,000298 & 0,000231 & 0,000183 & 0,000127 \\
\hline bta-miR-378 & 0,016802 & 0,001515 & 0,012555 & 0,002639 \\
\hline bta-miR-378b & $0,015470^{a}$ & 0,002936 & $0,010368^{b}$ & 0,000715 \\
\hline bta-miR-378c & 0,001568 & 0,000220 & 0,001089 & 0,000303 \\
\hline bta-miR-378d & \multicolumn{2}{|c|}{ ND } & \multicolumn{2}{|c|}{ ND } \\
\hline bta-miR-379 & 0,001490 & 0,000742 & 0,001153 & 0,000093 \\
\hline bta-miR-380-3p & 0,000411 & 0,000148 & 0,000210 & $0,00012 \epsilon$ \\
\hline bta-miR-380-5p & \multicolumn{2}{|c|}{ ND } & 0,000542 & 0,00015 \\
\hline bta-miR-381 & 0,000655 & 0,000256 & 0,000544 & 0,00008 \\
\hline bta-miR-382 & 0,000957 & 0,000520 & 0,000806 & $0,00017 €$ \\
\hline bta-miR-383 & \multicolumn{2}{|c|}{ ND } & \multicolumn{2}{|c|}{$\mathrm{N}$} \\
\hline bta-miR-409a & 0,000110 & 0,000085 & \multicolumn{2}{|c|}{ ND } \\
\hline bta-miR-409b & \multicolumn{2}{|c|}{ ND } & \\
\hline bta-miR-410 & \multicolumn{2}{|c|}{ ND } & \multicolumn{2}{|c|}{ ND } \\
\hline bta-miR-411a & 0,001258 & 0,001122 & 0,000785 & 0,00007 \\
\hline bta-miR-411b & \multicolumn{2}{|c|}{ ND } & \multicolumn{2}{|c|}{ ND } \\
\hline bta-miR-411c-3p & 0,000492 & 0,000495 & \multicolumn{2}{|c|}{ ND } \\
\hline bta-miR-411c-5p & 0,000268 & 0,000245 & 0,000121 & 0,000052 \\
\hline bta-miR-412 & 0,000101 & 0,000054 & \multicolumn{2}{|c|}{ ND } \\
\hline bta-miR-421 & 0,004266 & 0,000480 & 0,005511 & 0,000897 \\
\hline bta-miR-423-3p & 0,004160 & 0,000836 & 0,003715 & 0,000508 \\
\hline bta-miR-423-5p & 0,002310 & 0,000505 & 0,002467 & 0,000445 \\
\hline
\end{tabular}




\begin{tabular}{|c|c|c|c|c|}
\hline bta-miR-424-3p & \multicolumn{2}{|c|}{ ND } & \multicolumn{2}{|c|}{ ND } \\
\hline bta-miR-424-5p & 0,013530 & 0,004772 & 0,008336 & 0,001207 \\
\hline bta-miR-425-3p & \multicolumn{2}{|c|}{ ND } & \multicolumn{2}{|c|}{ ND } \\
\hline bta-miR-425-5p & 0,002016 & 0,000497 & 0,001815 & 0,000228 \\
\hline bta-miR-429 & 0,000817 & 0,000347 & 0,000676 & 0,000214 \\
\hline bta-miR-431 & 0,001502 & 0,000417 & 0,001276 & 0,000083 \\
\hline bta-miR-432 & 0,000427 & 0,000160 & 0,000352 & 0,000166 \\
\hline bta-miR-433 & 0,001209 & 0,000097 & 0,001018 & 0,000171 \\
\hline bta-miR-448 & \multicolumn{2}{|c|}{ ND } & \multicolumn{2}{|c|}{ ND } \\
\hline bta-miR-449a & 0,002098 & 0,000906 & 0,001327 & 0,000195 \\
\hline bta-miR-449b & \multicolumn{2}{|c|}{ ND } & 0,000236 & 0,000098 \\
\hline bta-miR-449c & 0,001008 & 0,000774 & 0,000923 & 0,000185 \\
\hline bta-miR-449d & \multicolumn{2}{|c|}{ ND } & \multicolumn{2}{|c|}{ ND } \\
\hline bta-miR-450a & 0,000334 & 0,000256 & \multicolumn{2}{|c|}{ ND } \\
\hline bta-miR-450b & \multicolumn{2}{|c|}{ ND } & \multicolumn{2}{|c|}{ ND } \\
\hline bta-miR-451 & \multicolumn{2}{|c|}{ ND } & \multicolumn{2}{|c|}{ ND } \\
\hline bta-miR-452 & 0,000274 & 0,000073 & 0,000215 & 0,000189 \\
\hline bta-miR-4523 & \multicolumn{2}{|c|}{ ND } & \multicolumn{2}{|c|}{ ND } \\
\hline bta-miR-453 & 0,000504 & 0,000060 & 0,000622 & 0,000109 \\
\hline bta-miR-454 & \multicolumn{2}{|c|}{ ND } & 0,000191 & 0,000057 \\
\hline bta-miR-455-3p & \multicolumn{2}{|c|}{ ND } & \multicolumn{2}{|c|}{ ND } \\
\hline bta-miR-455-5p & 0,000155 & 0,000092 & \multicolumn{2}{|c|}{ ND } \\
\hline bta-miR-483 & 0,000134 & 0,000040 & 0,000133 & 0,000101 \\
\hline bta-miR-484 & 0,000742 & 0,000025 & 0,000615 & 0,000254 \\
\hline bta-miR-485 & \multicolumn{2}{|c|}{ ND } & \multicolumn{2}{|c|}{ ND } \\
\hline bta-miR-486 & 0,008368 & 0,001908 & 0,009680 & 0,003245 \\
\hline bta-miR-487a & \multicolumn{2}{|c|}{ ND } & 0,000543 & 0,000283 \\
\hline bta-miR-487b & 0,000326 & 0,000258 & 0,000141 & 0,000084 \\
\hline bta-miR-488 & 0,000513 & 0,000203 & 0,000424 & 0,000111 \\
\hline bta-miR-489 & 0,000131 & 0,000027 & \multicolumn{2}{|c|}{ ND } \\
\hline bta-miR-490 & \multicolumn{2}{|c|}{ ND } & 0,001210 & 0,000619 \\
\hline bta-miR-491 & 0,000250 & 0,000142 & & \\
\hline bta-miR-493 & 0,008685 & 0,001652 & & \\
\hline bta-miR-494 & 2,766477 & 0,345955 & 3,194450 & 1,124804 \\
\hline bta-miR-495 & & & & \\
\hline bta-miR-496 & 0,000109 & 0,000082 & 0,000096 & 0,000070 \\
\hline bta-miR-497 & 0,000716 & 0,000104 & 0,000716 & 0,000168 \\
\hline bta-miR-499 & 0,000096 & 0,000069 & & \\
\hline bta-miR-500 & 0,001262 & 0,000391 & 0,001263 & 0,000404 \\
\hline bta-miR-502a & & & & \\
\hline bta-miR-502b & & & & \\
\hline bta-miR-503-3p & 0,032026 & 0,009199 & 0,026995 & 0,004863 \\
\hline bta-miR-503-5p & 0,004346 & 0,002184 & 0,001612 & 0,000247 \\
\hline bta-miR-504 & 0,000813 & 0,000517 & & \\
\hline
\end{tabular}




\begin{tabular}{|c|c|c|c|c|}
\hline bta-miR-505 & 0,003078 & 0,000217 & 0,002669 & 0,000272 \\
\hline bta-miR-532 & 0,001179 & 0,000223 & 0,001247 & 0,000507 \\
\hline bta-miR-539 & 0,000202 & 0,000133 & 0,000114 & 0,000020 \\
\hline bta-miR-541 & 0,003354 & 0,000232 & 0,003373 & 0,001013 \\
\hline bta-miR-542-5p & 0,000187 & 0,000098 & \multicolumn{2}{|c|}{ ND } \\
\hline bta-miR-543 & 0,000318 & 0,000241 & 0,000215 & 0,000122 \\
\hline bta-miR-544a & \multicolumn{2}{|c|}{ ND } & \multicolumn{2}{|c|}{ ND } \\
\hline bta-miR-544b & 0,000159 & 0,000025 & \multicolumn{2}{|c|}{ ND } \\
\hline bta-miR-545-3p & 0,000210 & 0,000130 & 0,000298 & 0,000208 \\
\hline bta-miR-545-5p & 0,000279 & 0,000184 & \multicolumn{2}{|c|}{ ND } \\
\hline bta-miR-551a & \multicolumn{2}{|c|}{ ND } & \multicolumn{2}{|c|}{ ND } \\
\hline bta-miR-551b & \multicolumn{2}{|c|}{ ND } & \multicolumn{2}{|c|}{ ND } \\
\hline bta-miR-574 & 0,141889 & 0,029544 & 0,127980 & 0,039946 \\
\hline bta-miR-584 & \multicolumn{2}{|c|}{ ND } & \multicolumn{2}{|c|}{ ND } \\
\hline bta-miR-592 & 0,000381 & 0,000008 & 0,000441 & 0,000040 \\
\hline bta-miR-615 & 420,575487 & 109,357699 & 352,724073 & 87,013235 \\
\hline bta-miR-628 & \multicolumn{2}{|c|}{ ND } & \multicolumn{2}{|c|}{ ND } \\
\hline bta-miR-631 & 1,535186 & 0,225185 & 1,404892 & 0,221630 \\
\hline bta-miR-652 & 0,002250 & 0,000230 & 0,002096 & 0,000209 \\
\hline bta-miR-654 & 0,006276 & 0,001883 & 0,005889 & 0,001827 \\
\hline bta-miR-655 & \multicolumn{2}{|c|}{ ND } & \multicolumn{2}{|c|}{ ND } \\
\hline bta-miR-656 & 0,000257 & 0,000113 & 0,000276 & 0,000037 \\
\hline bta-miR-658 & 0,002665 & 0,000399 & 0,002867 & 0,000745 \\
\hline bta-miR-660 & 0,001521 & 0,000684 & \multicolumn{2}{|c|}{ ND } \\
\hline bta-miR-664a & 0,018613 & 0,005344 & 0,018738 & 0,003497 \\
\hline bta-miR-664b & 0,006484 & 0,001814 & 0,006783 & 0,000717 \\
\hline bta-miR-665 & 0,025948 & 0,004018 & 0,029323 & 0,005238 \\
\hline bta-miR-669 & 0,049626 & 0,005529 & 0,044333 & 0,007570 \\
\hline bta-miR-670 & \multicolumn{2}{|c|}{ ND } & \multicolumn{2}{|c|}{ ND } \\
\hline bta-miR-671 & \multicolumn{2}{|c|}{ ND } & \multicolumn{2}{|c|}{ ND } \\
\hline bta-miR-677 & 0,129555 & 0,022456 & 0,133903 & 0,015336 \\
\hline bta-miR-7 & 0,012303 & 0,003969 & 0,014095 & 0,004916 \\
\hline bta-miR-708 & 0,000965 & 0,000187 & 0,000938 & 0,000159 \\
\hline bta-miR-744 & 0,001565 & 0,000312 & 0,001486 & 0,000157 \\
\hline bta-miR-758 & \multicolumn{2}{|c|}{ ND } & \multicolumn{2}{|c|}{ ND } \\
\hline bta-miR-760-3p & 0,003009 & 0,000643 & 0,002430 & 0,001097 \\
\hline bta-miR-760-5p & 0,015170 & 0,002419 & \multicolumn{2}{|c|}{ ND } \\
\hline bta-miR-761 & \multicolumn{2}{|c|}{ ND } & 0,000262 & 0,000189 \\
\hline bta-miR-763 & \multicolumn{2}{|c|}{ ND } & 0,002464 & 0,000108 \\
\hline bta-miR-764 & 0,000178 & 0,000021 & $\mathrm{~N}$ & \\
\hline bta-miR-767 & 0,000765 & 0,000156 & 0,000600 & 0,000254 \\
\hline bta-miR-769 & & & $\mathrm{N}$ & \\
\hline bta-miR-873 & & & 0,000621 & 0,000302 \\
\hline bta-miR-874 & 0,009683 & 0,002360 & 0,012071 & 0,002753 \\
\hline
\end{tabular}




\begin{tabular}{|c|c|c|c|c|}
\hline bta-miR-875 & \multicolumn{2}{|c|}{ ND } & \multicolumn{2}{|c|}{ ND } \\
\hline bta-miR-876 & \multicolumn{2}{|c|}{ ND } & \multicolumn{2}{|c|}{ ND } \\
\hline bta-miR-877 & 0,015559 & 0,002886 & 0,018626 & 0,004690 \\
\hline bta-miR-885 & 0,001344 & 0,000268 & \multicolumn{2}{|c|}{ ND } \\
\hline bta-miR-92a & 0,026056 & 0,008353 & 0,028445 & 0,003946 \\
\hline bta-miR-92b & 0,019912 & 0,004212 & 0,019111 & 0,001400 \\
\hline bta-miR-93 & 0,023387 & 0,000501 & 0,022373 & 0,004299 \\
\hline bta-miR-935 & \multicolumn{2}{|c|}{ ND } & \multicolumn{2}{|c|}{ ND } \\
\hline bta-miR-9-3p & \multicolumn{2}{|c|}{ ND } & \multicolumn{2}{|c|}{ ND } \\
\hline bta-miR-940 & 0,310951 & 0,212843 & 0,177820 & 0,031243 \\
\hline bta-miR-95 & 0,000301 & 0,000135 & 0,000188 & 0,000140 \\
\hline bta-miR-9-5p & 0,010149 & 0,002377 & 0,012209 & 0,002812 \\
\hline bta-miR-96 & 0,000454 & 0,000118 & 0,000406 & 0,000169 \\
\hline bta-miR-98 & \multicolumn{2}{|c|}{ ND } & 0,000151 & 0,000086 \\
\hline bta-miR-99a-3p & \multicolumn{2}{|c|}{ ND } & \multicolumn{2}{|c|}{ ND } \\
\hline bta-miR-99a-5p & \multicolumn{2}{|c|}{ ND } & 0,000221 & 0,000112 \\
\hline bta-miR-99b & 0,046660 & 0,007197 & 0,040226 & 0,008030 \\
\hline
\end{tabular}


Tabela suplementar S.4. Expressão relativa dos 93 RNAm avaliados para 8 repetições biológicas para embriões cultivados em alta e baixa tensão de oxigênio.

\begin{tabular}{|c|c|c|c|c|}
\hline & \multicolumn{2}{|c|}{ Alto $\mathrm{O}_{2}$} & \multicolumn{2}{|c|}{ Baixo $\mathrm{O}_{2}$} \\
\hline Genes & Média & DP & Média & DP \\
\hline ACACA & 0,0140 & 0,0055 & 0,0102 & 0,0048 \\
\hline ACSL3 & $0,0733^{a}$ & 0,0158 & $0,0456^{b}$ & 0,0162 \\
\hline ACSL6 & 0,0299 & 0,0062 & 0,0226 & 0,0089 \\
\hline AQP3 & 0,1160 & 0,0233 & 0,1025 & 0,0206 \\
\hline ATF4 & 0,0684 & 0,0235 & 0,0575 & 0,0119 \\
\hline ATP5L & $0,3098^{a}$ & 0,0352 & $0,2635^{b}$ & 0,0177 \\
\hline BAX & $0,0588^{a}$ & 0,0144 & $0,0396^{b}$ & 0,0137 \\
\hline BCL2 & \multicolumn{2}{|c|}{ ND } & \multicolumn{2}{|c|}{ ND } \\
\hline BID & $0,0065^{a}$ & 0,0009 & $0,0047^{b}$ & 0,0014 \\
\hline CASP3 & 0,0033 & 0,0014 & 0,0022 & 0,0008 \\
\hline CASP9 & $0,0075^{a}$ & 0,0017 & $0,0050^{b}$ & 0,0019 \\
\hline CAT & $0,0204^{a}$ & 0,0040 & $0,0143^{b}$ & 0,0032 \\
\hline CCND2 & $0,0486^{a}$ & 0,0125 & $0,0356^{b}$ & 0,0094 \\
\hline CDCA8 & $0,0272^{a}$ & 0,0062 & $0,0173^{b}$ & 0,0052 \\
\hline CDK6 & 0,0012 & 0,0005 & 0,0008 & 0,0005 \\
\hline $\mathrm{CDX} 2$ & 0,0286 & 0,0051 & 0,0244 & 0,0026 \\
\hline DDIT3 & 0,0067 & 0,0019 & 0,0075 & 0,0027 \\
\hline Dnmt1 & 0,0042 & 0,0015 & 0,0033 & 0,0016 \\
\hline Dnmt3A & $0,1587^{a}$ & 0,0368 & $0,0992^{b}$ & 0,0381 \\
\hline Dnmt3B & 0,0663 & 0,0193 & 0,0506 & 0,0174 \\
\hline EGFR & $0,0083^{a}$ & 0,0027 & $0,0054^{b}$ & 0,0014 \\
\hline ELF5 & \multicolumn{2}{|c|}{ ND } & \multicolumn{2}{|c|}{ ND } \\
\hline ELOVL6 & 0,1360 & 0,0237 & 0,1292 & 0,0477 \\
\hline FADS2 & 0,0435 & 0,0231 & 0,0315 & 0,0171 \\
\hline FASN & 0,1587 & 0,0455 & 0,1166 & 0,0361 \\
\hline FOXO3 & 0,0035 & 0,0013 & 0,0032 & 0,0015 \\
\hline G6PD & 0,0359 & 0,0104 & 0,0332 & 0,0110 \\
\hline GADD45A & 0,0090 & 0,0028 & 0,0071 & 0,0019 \\
\hline GLRX2 & $0,0225^{a}$ & 0,0051 & $0,0138^{b}$ & 0,0026 \\
\hline GPX1 & 0,1205 & 0,0302 & 0,1243 & 0,0176 \\
\hline GPX4 & 0,0747 & 0,0241 & 0,0631 & 0,0132 \\
\hline GSK3A & 0,0287 & 0,0081 & 0,0230 & 0,0047 \\
\hline $\mathrm{H} 19$ & \multicolumn{2}{|c|}{ ND } & \multicolumn{2}{|c|}{ ND } \\
\hline H1FOO & \multicolumn{2}{|c|}{ ND } & \multicolumn{2}{|c|}{ ND } \\
\hline H2AFZ & $0,1475^{a}$ & 0,0440 & $0,0876^{b}$ & 0,0303 \\
\hline H3F3A & \multicolumn{2}{|c|}{ ND } & \multicolumn{2}{|c|}{ ND } \\
\hline H3F3B & $0,0080^{a}$ & 0,0024 & $0,0053^{b}$ & 0,0025 \\
\hline HAND1 & $0,0037^{a}$ & 0,0008 & $0,0027^{b}$ & 0,0011 \\
\hline HDAC2 & 0,0133 & 0,0030 & 0,0081 & 0,0021 \\
\hline HIF1A & 0,0053 & 0,0022 & 0,0038 & 0,0017 \\
\hline HP1 & 0,0066 & 0,0021 & 0,0052 & 0,0018 \\
\hline HSF1 & $0,0379^{a}$ & 0,0098 & $0,0278^{b}$ & 0,0063 \\
\hline HSP9OAA1 & $0,6412^{a}$ & 0,1272 & $0,4061^{b}$ & 0,0510 \\
\hline
\end{tabular}




\begin{tabular}{|c|c|c|c|c|}
\hline HSPA1A & 0,0078 & 0,0046 & 0,0091 & 0,0054 \\
\hline HSPA5 & 0,1711 & 0,0283 & 0,1278 & 0,0565 \\
\hline HSPD1 & $0,1359^{a}$ & 0,0253 & $0,0851^{b}$ & 0,0271 \\
\hline LIPE & 0,0005 & 0,0004 & 0,0007 & 0,0004 \\
\hline LUM & \multicolumn{2}{|c|}{ ND } & \multicolumn{2}{|c|}{ ND } \\
\hline KEAP1 & $0,0103^{a}$ & 0,0020 & $0,0076^{b}$ & 0,0027 \\
\hline IFNT2 & $0,0172^{a}$ & 0,0046 & $0,0098^{b}$ & 0,0054 \\
\hline IMPDH2 & 0,0396 & 0,0085 & 0,0312 & 0,0080 \\
\hline IMPDH1 & 0,0085 & 0,0035 & 0,0067 & 0,0028 \\
\hline IGF1R & 0,0089 & 0,0029 & 0,0067 & 0,0035 \\
\hline NFE2L2 & $0,0094^{a}$ & 0,0029 & $0,0058^{b}$ & 0,0015 \\
\hline NANOG & $0,0075^{a}$ & 0,0041 & $0,0030^{b}$ & 0,0013 \\
\hline MTIF3 & 0,0022 & 0,0010 & 0,0015 & 0,0010 \\
\hline MORF4L2 & $0,0061^{a}$ & 0,0014 & $0,0040^{b}$ & 0,0016 \\
\hline MAPK1 & $0,0306^{a}$ & 0,0090 & $0,0220^{b}$ & 0,0061 \\
\hline PA2G4 & $0,0528^{a}$ & 0,0122 & $0,0370^{b}$ & 0,0101 \\
\hline OTX2 & $0,0350^{a}$ & 0,0141 & $0,0205^{b}$ & 0,0070 \\
\hline NR1H3 & 0,0006 & 0,0002 & 0,0005 & 0,0003 \\
\hline NOS2 & 0,0047 & 0,0017 & 0,0057 & 0,0025 \\
\hline NOS3 & \multicolumn{2}{|c|}{ ND } & \multicolumn{2}{|c|}{ ND } \\
\hline NFkB2 & 0,0102 & 0,0023 & 0,0070 & 0,003 \\
\hline PPARA & \multicolumn{2}{|c|}{ ND } & \multicolumn{2}{|c|}{ ND } \\
\hline PPARG & $0,0005^{a}$ & 0,0003 & $0,0001^{b}$ & 0,000 \\
\hline PPARGC1A & \multicolumn{2}{|c|}{ ND } & \multicolumn{2}{|c|}{ ND } \\
\hline POU5F1 & 0,3006 & 0,0551 & 0,2478 & 0,0631 \\
\hline PGK1 & $0,0256^{a}$ & 0,0038 & $0,0551^{b}$ & 0,0146 \\
\hline PFKP & 0,0011 & 0,0006 & 0,0012 & 0,0009 \\
\hline PAF1 & $0,0181^{a}$ & 0,0037 & $0,0138^{b}$ & 0,0043 \\
\hline PTGS2 & $0,1674^{a}$ & 0,0342 & $0,1038^{b}$ & 0,0324 \\
\hline PRKCD & $0,0067^{a}$ & 0,0015 & $0,0048^{b}$ & 0,0019 \\
\hline PRDX3 & $0,0178^{a}$ & 0,0023 & $0,0137^{b}$ & 0,0035 \\
\hline PRDX1 & $0,5321^{a}$ & 0,0967 & $0,3912^{b}$ & 0,0559 \\
\hline sox2 & 0,0156 & 0,0068 & 0,0114 & 0,0056 \\
\hline SOD2 & 0,0222 & 0,0160 & 0,0162 & 0,0070 \\
\hline SOD1 & $0,0380^{a}$ & 0,0061 & $0,0264^{b}$ & 0,0074 \\
\hline $\mathrm{SCD}$ & 0,0500 & 0,0161 & 0,0474 & 0,0195 \\
\hline SALL4 & 0,0609 & 0,0191 & 0,0443 & 0,0167 \\
\hline REST & $0,0048^{a}$ & 0,0012 & $0,0033^{b}$ & 0,0011 \\
\hline TNFAIP6 & \multicolumn{2}{|c|}{ ND } & \multicolumn{2}{|c|}{ ND } \\
\hline TNF & \multicolumn{2}{|c|}{ ND } & \multicolumn{2}{|c|}{ ND } \\
\hline TFAM & $0,0136^{a}$ & 0,0045 & $0,0073^{b}$ & 0,0019 \\
\hline STAT3 & $0,0318^{a}$ & 0,0107 & $0,0157^{b}$ & 0,0047 \\
\hline SREBF2 & 0,0510 & 0,0135 & 0,0447 & 0,0142 \\
\hline SREBF1 & $0,0039^{a}$ & 0,0014 & $0,0024^{b}$ & 0,0007 \\
\hline XBP1 & 0,0310 & 0,0128 & 0,0218 & 0,0104 \\
\hline VEGFA & 0,0108 & 0,0034 & 0,0136 & 0,004 \\
\hline VNN1 & \multicolumn{2}{|c|}{ ND } & \multicolumn{2}{|c|}{ ND } \\
\hline TXNRD1 & $0,0418^{a}$ & 0,0080 & $0,0315^{b}$ & 0,009 \\
\hline
\end{tabular}




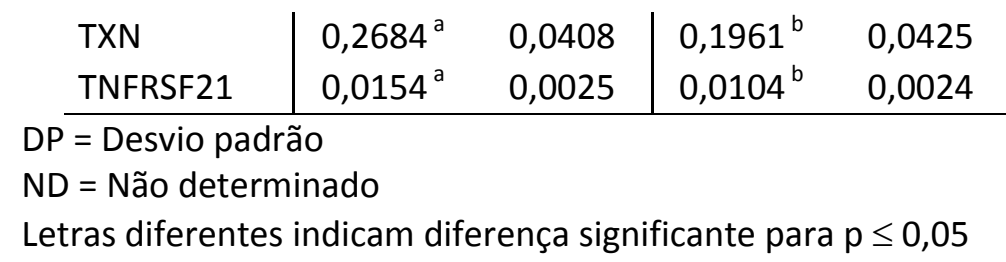


Tabela suplementar S.5. Expressão relativa dos 8 miRNAs avaliados para 4 repetições biológicas de blastocistos bovinos produzidos por fertilização in vitro e cultivados em alta tensão de oxigênio na ausência e presença de suplementação do meio de cultivo com antioxidantes (cisteína e cisteamina).

\begin{tabular}{l|cc|cc}
\hline \multicolumn{1}{c}{ Alto $\mathbf{O}_{\mathbf{2}}$} & \multicolumn{2}{c}{ Alto $\mathbf{O}_{\mathbf{2}} \mathbf{C + C}$} \\
\hline \multicolumn{1}{c|}{ miRNA } & Média & DP & Média & DP \\
\hline bta-miR-378b & 0,015492 & 0,002474 & 0,0135923 & 0,005465 \\
bta-miR-34c & 0,000819 & 0,000045 & 0,0007618 & 0,000211 \\
bta-miR-19a & 0,003942 & 0,002048 & 0,0023332 & 0,001342 \\
bta-miR-155 & 0,000295 & 0,000089 & 0,0005147 & 0,000313 \\
bta-miR-1260b & 1,108667 & 0,183919 & 1,5459604 & 0,904383 \\
bta-miR-22-5p & 0,000428 & 0,000082 & 0,0004917 & 0,000229 \\
bta-miR-210 & 0,003038 & 0,000290 & 0,0025527 & 0,000457 \\
bta-miR-140 & 0,000211 & 0,000026 & 0,0001709 & 0,000033 \\
\hline DP = Desvio padrão & & & \\
ND = Não determinado
\end{tabular}


Tabela suplementar S.6.Lista completa da expressão relativa dos miRNAs do conteúdo dos exossomos isolados do meio de cultivo nos dias 3 e 7 do cultivo de embriões produzidos por fertilização in vitro e expostos a diferentes condições atmosféricas, alta e baixa tensão de oxigênio para 3 repetições biológicas.

Meio de Cultivo D3

Meio de Cultivo D7

\begin{tabular}{|c|c|c|c|c|c|c|c|c|}
\hline & \multicolumn{2}{|c|}{ Alto $\mathrm{O}_{2}$} & \multicolumn{2}{|c|}{ Baixo $\mathrm{O}_{2}$} & \multicolumn{2}{|c|}{ Alto $\mathrm{O}_{2}$} & \multicolumn{2}{|c|}{ Baixo $\mathrm{O}_{2}$} \\
\hline miRNA & Média & DP & Média & DP & Média & DP & Média & DP \\
\hline bta-let-7a-3p & 0,000053 & 0,000026 & 0,000046 & 0,000006 & 0,000394 & 0,000128 & 0,000246 & 0,000156 \\
\hline bta-let-7a-5p & 0,004216 & 0,001518 & 0,006361 & 0,005002 & 0,027993 & 0,007275 & 0,013952 & 0,007279 \\
\hline bta-let-7b & 0,016006 & 0,003516 & 0,021152 & 0,004032 & 0,016345 & 0,005207 & 0,011395 & 0,001806 \\
\hline bta-let-7c & 0,013826 & 0,004203 & 0,019434 & 0,005022 & $0,022220^{a}$ & 0,00179 & $0,014038^{b}$ & 0,003194 \\
\hline bta-let-7d & 0,001298 & 0,000745 & 0,002503 & 0,002085 & 0,011030 & 0,002793 & 0,005640 & 0,002549 \\
\hline bta-let-7e & 0,005294 & 0,002638 & 0,009220 & 0,004365 & 0,027226 & 0,011835 & 0,012801 & 0,003965 \\
\hline bta-let-7f & 0,001858 & 0,000984 & 0,002809 & 0,001911 & 0,011347 & 0,003275 & 0,006024 & 0,003095 \\
\hline bta-let-7g & 0,007274 & 0,001574 & 0,009008 & 0,000732 & 0,009749 & 0,001767 & 0,006428 & 0,003435 \\
\hline bta-let-7i & 0,007614 & 0,001787 & 0,010129 & 0,002461 & 0,014200 & 0,005682 & 0,007126 & 0,001504 \\
\hline bta-miR-1 & \multicolumn{2}{|c|}{ ND } & \multicolumn{2}{|c|}{ ND } & \multicolumn{2}{|c|}{ ND } & \multicolumn{2}{|c|}{ ND } \\
\hline bta-miR-100 & 0,001130 & 0,000610 & 0,001954 & 0,000658 & 0,004866 & 0,002186 & 0,003038 & 0,000765 \\
\hline bta-miR-101 & 0,004199 & 0,000622 & 0,005291 & 0,001448 & 0,008580 & 0,003875 & 0,006716 & 0,002761 \\
\hline bta-miR-103 & 0,002404 & 0,000393 & 0,002243 & 0,000287 & 0,009868 & 0,00348 & 0,006688 & 0,001997 \\
\hline bta-miR-105a & \multicolumn{2}{|c|}{ ND } & \multicolumn{2}{|c|}{ ND } & \multicolumn{2}{|c|}{ ND } & 0,000433 & 0,0006 \\
\hline bta-miR-105b & \multicolumn{2}{|c|}{ ND } & \multicolumn{2}{|c|}{ ND } & \multicolumn{2}{|c|}{ ND } & \multicolumn{2}{|c|}{ ND } \\
\hline bta-miR-106a & 0,059105 & 0,011821 & 0,077520 & 0,008662 & 0,075695 & 0,032331 & 0,061637 & 0,01364 \\
\hline bta-miR-106b & 0,016475 & 0,004662 & 0,018395 & 0,002810 & 0,021240 & 0,010335 & 0,013631 & 0,003669 \\
\hline bta-miR-107 & \multicolumn{2}{|c|}{ ND } & \multicolumn{2}{|c|}{ ND } & 0,000786 & 0,000456 & 0,000329 & 0,000206 \\
\hline bta-miR-10a & 0,000624 & 0,000363 & 0,000534 & 0,000176 & 0,002592 & 0,000924 & 0,001609 & 0,000667 \\
\hline bta-miR-10b & 0,001080 & 0,000123 & 0,001348 & 0,000282 & 0,003910 & 0,001168 & 0,003282 & 0,000963 \\
\hline bta-miR-1179 & \multicolumn{2}{|c|}{ ND } & \multicolumn{2}{|c|}{ ND } & \multicolumn{2}{|c|}{ ND } & \multicolumn{2}{|c|}{ ND } \\
\hline bta-miR-1185 & \multicolumn{2}{|c|}{ ND } & \multicolumn{2}{|c|}{ ND } & \multicolumn{2}{|c|}{ ND } & \multicolumn{2}{|c|}{ ND } \\
\hline bta-miR-1193 & & & & & $\mathrm{N}$ & & $\mathrm{N}$ & \\
\hline bta-miR-1197 & & & & & $\mathrm{N}$ & & $\mathrm{N}$ & \\
\hline bta-miR-122 & 0,000316 & 0,000044 & 0,000229 & 0,000117 & 0,000562 & 0,000258 & $\mathrm{~N}$ & \\
\hline bta-miR-122 & 0,000247 & 0,000081 & 0,000157 & 0,000025 & 0,000467 & 0,000202 & 0,000603 & 0,000056 \\
\hline bta-miR-1224 & 0,021057 & 0,010745 & 0,017470 & 0,007456 & $0,322673^{a}$ & 0,082482 & $0,14715^{b}$ & 0,081556 \\
\hline bta-miR-1225-3p & 0,001642 & 0,000544 & 0,002356 & 0,000103 & $\mathrm{~N}$ & & $\mathrm{~N}$ & \\
\hline bta-miR-1246 & 3,925356 & 0,921643 & 5,883385 & 0,999932 & 7,142996 & 1,255276 & 9,761624 & 3,301708 \\
\hline bta-miR-1247-3p & 0,000916 & 0,000190 & 0,001170 & 0,000345 & 0,004406 & 0,003501 & 0,005345 & 0,006607 \\
\hline bta-miR-1247-5p & 0,000739 & 0,000529 & 0,001396 & 0,000836 & 0,011492 & 0,00584 & $\mathrm{~N}$ & \\
\hline bta-miR-1248 & & & & & 0,000198 & 0,000119 & 0,000192 & 0,000152 \\
\hline bta-miR-1249 & & & & & $\mathrm{N}$ & & 0,000674 & 0,00081 \\
\hline bta-miR-124a & 0,000142 & 0,000121 & & & 0,000322 & 0,000203 & $\mathrm{~N}$ & \\
\hline bta-miR-124b & 0,000094 & 0,000054 & 0,000122 & 0,000052 & 0,000337 & 0,000317 & 0,000541 & 0,000696 \\
\hline bta-miR-125a & $0,007865^{a}$ & 0,003027 & $0,014014^{b}$ & 0,002159 & 0,017496 & 0,005657 & 0,010529 & 0,003164 \\
\hline bta-miR-125b & $0,014730^{a}$ & 0,005284 & $0,024617^{b}$ & 0,003299 & 0,069636 & 0,023783 & 0,038821 & 0,012363 \\
\hline
\end{tabular}




\begin{tabular}{|c|c|c|c|c|c|c|c|c|}
\hline bta-miR-1260b & 0,012403 & 0,002990 & 0,012769 & 0,003687 & 0,129142 & 0,060097 & 0,114420 & 0,020387 \\
\hline bta-miR-126-3p & \multicolumn{2}{|c|}{ ND } & \multicolumn{2}{|c|}{ ND } & \multicolumn{2}{|c|}{ ND } & 0,000102 & 0,000045 \\
\hline bta-miR-126-5p & \multicolumn{2}{|c|}{ ND } & \multicolumn{2}{|c|}{ ND } & 0,000086 & 0,000039 & \multicolumn{2}{|c|}{ ND } \\
\hline bta-miR-127 & 0,000226 & 0,000102 & 0,000140 & 0,000049 & 0,001571 & 0,00184 & 0,001933 & 0,002175 \\
\hline bta-miR-1271 & 0,000183 & 0,000122 & 0,000147 & 0,000048 & 0,001084 & 0,000327 & 0,000772 & 0,00024 \\
\hline bta-miR-1277 & \multicolumn{2}{|c|}{ ND } & \multicolumn{2}{|c|}{ ND } & \multicolumn{2}{|c|}{ ND } & \multicolumn{2}{|c|}{ ND } \\
\hline bta-miR-128 & \multicolumn{2}{|c|}{ ND } & 0,000083 & 0,000043 & 0,001012 & 0,000686 & 0,000606 & 0,00053 \\
\hline bta-miR-1281 & 0,000610 & 0,000405 & 0,000662 & 0,000098 & 0,013335 & 0,0203 & 0,025750 & 0,040497 \\
\hline bta-miR-1282 & \multicolumn{2}{|c|}{ ND } & \multicolumn{2}{|c|}{ ND } & \multicolumn{2}{|c|}{ ND } & \multicolumn{2}{|c|}{ ND } \\
\hline bta-miR-1284 & \multicolumn{2}{|c|}{ ND } & \multicolumn{2}{|c|}{ ND } & 0,000236 & 0,000265 & 0,000619 & 0,00096 \\
\hline bta-miR-1287 & \multicolumn{2}{|c|}{ ND } & \multicolumn{2}{|c|}{ ND } & 0,000176 & 0,000151 & 0,000219 & 0,00021 \\
\hline bta-miR-129 & 0,000159 & 0,000041 & 0,000090 & 0,000023 & & & $\mathrm{~N}$ & \\
\hline bta-miR-1291 & \multicolumn{2}{|c|}{ ND } & \multicolumn{2}{|c|}{ ND } & 0,000672 & 0,000991 & 0,001213 & 0,001872 \\
\hline bta-miR-129-3p & \multicolumn{2}{|c|}{ ND } & 0,000102 & 0,000026 & 0,000477 & 0,000155 & 0,000452 & 0,000233 \\
\hline bta-miR-129-5p & $0,000087^{\mathrm{a}}$ & 0,000018 & $0,000051^{b}$ & 0,000014 & 0,000969 & 0,001315 & 0,002304 & 0,003668 \\
\hline bta-miR-1296 & \multicolumn{2}{|c|}{ ND } & 0,000099 & 0,000046 & 0,003208 & 0,00491 & 0,007226 & 0,011331 \\
\hline bta-miR-1298 & & D & & & & & 0,000100 & 0,000098 \\
\hline bta-miR-1301 & & D & & & & & $\mathrm{N}$ & \\
\hline bta-miR-1306 & 0,000262 & 0,000058 & 0,000220 & 0,000151 & & & 0,001316 & 0,000322 \\
\hline bta-miR-1307 & 0,000799 & 0,000102 & & & & & 0,005298 & 0,003473 \\
\hline bta-miR-130a & 0,002090 & 0,000581 & 0,001663 & 0,000759 & 0,005000 & 0,002663 & 0,003953 & 0,001437 \\
\hline bta-miR-130b & 0,002077 & 0,000754 & 0,001515 & 0,000570 & 0,005146 & 0,002455 & 0,003277 & 0,001431 \\
\hline bta-miR-132 & 0,011368 & 0,004978 & 0,014864 & 0,002155 & $0,006033^{a}$ & 0,001734 & $0,013094^{b}$ & 0,003733 \\
\hline bta-miR-133a & 0,000097 & 0,000013 & & & 0,000584 & 0,000732 & 0,000897 & 0,001236 \\
\hline bta-miR-133b & & & & & & & $\mathrm{N}$ & \\
\hline bta-miR-133c & & & & & & & $\mathrm{N}$ & \\
\hline bta-miR-134 & & D & & & & & 0,000806 & 0,001205 \\
\hline bta-miR-1343-3p & 0,000384 & 0,000117 & 0,000460 & 0,000178 & 0,004078 & 0,002963 & 0,006614 & 0,007571 \\
\hline bta-miR-1343-5p & 0,005362 & 0,001446 & 0,010665 & 0,006273 & 0,096209 & 0,116756 & 0,072942 & 0,082677 \\
\hline bta-miR-135a & & & 0,000094 & 0,000047 & & & 0,000047 & 0,000018 \\
\hline bta-miR-135b & & & & & 0,000071 & 0,0000305 & $\mathrm{~N}$ & \\
\hline bta-miR-136 & & & & & & & $\mathrm{N}$ & \\
\hline bta-miR-137 & & D & 0,000046 & 0,000016 & & & $\mathrm{~N}$ & \\
\hline bta-miR-138 & 0,000412 & 0,000256 & & & 0,001704 & 0,00089 & 0,002059 & 0,001198 \\
\hline bta-miR-1388-3p & 0,000288 & 0,000050 & 0,000233 & 0,000131 & 0,001056 & 0,000823 & 0,001444 & 0,001889 \\
\hline bta-miR-139 & 0,000207 & 0,000063 & 0,000095 & 0,000040 & 0,000447 & 0,000314 & 0,000462 & 0,000567 \\
\hline bta-miR-140 & 0,000506 & 0,000107 & 0,000785 & 0,000320 & 0,003187 & 0,001935 & 0,001541 & 0,000725 \\
\hline bta-miR-141 & & $D$ & & & 0,000126 & 0,000046 & 0,000109 & 0,000114 \\
\hline bta-miR-142-3p & & & & & & & $N$ & \\
\hline bta-miR-142-5p & & $D$ & & & & & $\mathrm{~N}$ & \\
\hline bta-miR-143 & 0,000479 & 0,000182 & 0,000434 & 0,000176 & & & 0,001058 & 0,000282 \\
\hline bta-miR-144 & & & & & & & $\mathrm{N}$ & \\
\hline bta-miR-145 & & & & & & & $\mathrm{N}$ & \\
\hline bta-miR-146a & & & & & & & $\mathrm{N}$ & \\
\hline
\end{tabular}




\begin{tabular}{|c|c|c|c|c|c|c|c|c|}
\hline bta-miR-146b & \multicolumn{2}{|c|}{ ND } & \multicolumn{2}{|c|}{ ND } & 0,000100 & 0,000024 & \multicolumn{2}{|c|}{ ND } \\
\hline bta-miR-147 & \multicolumn{2}{|c|}{ ND } & \multicolumn{2}{|c|}{ ND } & \multicolumn{2}{|c|}{ ND } & \multicolumn{2}{|c|}{ ND } \\
\hline bta-miR-148a & 0,004438 & 0,000208 & 0,004807 & 0,000212 & 0,022441 & 0,008316 & 0,013946 & 0,004794 \\
\hline ta-miR-148b & 0,003685 & 0,000602 & 0,004261 & 0,000536 & 0,015866 & 0,004868 & 0,009669 & 0,002291 \\
\hline bta-miR-149-3p & 0,016122 & 0,006372 & 0,028339 & 0,008076 & 0,086046 & 0,08904 & 0,062329 & 0,053771 \\
\hline bta-miR-149-5p & \multicolumn{2}{|c|}{ ND } & \multicolumn{2}{|c|}{ ND } & 0,001086 & 0,00171 & 0,003263 & 0,005226 \\
\hline ta-miR-150 & \multicolumn{2}{|c|}{ ND } & \multicolumn{2}{|c|}{ ND } & \multicolumn{2}{|c|}{ ND } & \multicolumn{2}{|c|}{ ND } \\
\hline bta-miR-151-3p & 0,001318 & 0,000598 & 0,001793 & 0,000309 & 0,003417 & 0,001412 & 0,003118 & 0,000822 \\
\hline bta-miR-151-5p & 0,001260 & 0,000588 & 0,001306 & 0,000296 & 0,003968 & 0,001531 & 0,002655 & 0,000843 \\
\hline bta-miR-152 & 0,000119 & 0,000055 & 0,000130 & 0,000072 & 0,000676 & 0,000407 & 0,000754 & 0,000754 \\
\hline ta-miR-153 & \multicolumn{2}{|c|}{ ND } & \multicolumn{2}{|c|}{ ND } & \multicolumn{2}{|c|}{ ND } & 0,000059 & 0,000040 \\
\hline bta-miR-154a & \multicolumn{2}{|c|}{ ND } & \multicolumn{2}{|c|}{ ND } & \multicolumn{2}{|c|}{ ND } & \multicolumn{2}{|c|}{ ND } \\
\hline bta-miR-154b & 0,000098 & 0,000061 & 0,000058 & 0,000018 & & & $N$ & \\
\hline bta-miR-154c & \multicolumn{2}{|c|}{ ND } & \multicolumn{2}{|c|}{ ND } & \multicolumn{2}{|c|}{ ND } & $\mathrm{N}$ & \\
\hline bta-miR-155 & 0,018478 & 0,005583 & 0,026651 & 0,001019 & 0,026479 & 0,01057 & 0,021364 & 0,005935 \\
\hline bta-miR-15a & $0,016459^{a}$ & 0,003191 & $0,023170^{b}$ & 0,002800 & 0,024970 & 0,009791 & 0,026226 & 0,004554 \\
\hline bta-miR-15b & 0,002420 & 0,000714 & 0,003560 & 0,000703 & 0,007757 & 0,003547 & 0,004533 & 0,000694 \\
\hline bta-miR-16a & 0,055078 & 0,008133 & 0,068178 & 0,005740 & 0,073093 & 0,023726 & 0,066621 & 0,011601 \\
\hline bta-miR-16b & $0,079801^{a}$ & 0,015448 & $0,107801^{b}$ & 0,007672 & 0,114106 & 0,043119 & 0,109082 & 0,012491 \\
\hline bta-miR-17-3p & & D & 0,000079 & 0,000045 & 0,000404 & 0,00023 & 0,000356 & 0,000401 \\
\hline bta-miR-17-5p & 0,002180 & 0,000644 & 0,002870 & 0,000330 & 0,003886 & 0,001209 & 0,003199 & 0,001 \\
\hline bta-miR-181a & 0,000823 & 0,000301 & 0,000765 & 0,000403 & 0,001721 & 0,000834 & & \\
\hline bta-miR-181b & 0,001155 & 0,000173 & 0,001071 & 0,000236 & & & 0,001836 & 0,000632 \\
\hline bta-miR-181c & 0,000125 & 0,000106 & 0,000092 & 0,000033 & 0,000821 & 0,000263 & & \\
\hline bta-miR-181d & 0,001990 & 0,000264 & 0,001699 & 0,000165 & 0,002633 & 0,000479 & 0,002380 & 0,000549 \\
\hline bta-miR-182 & 0,000065 & 0,000020 & & & $0,001262^{a}$ & 0,000186 & $0,000417^{b}$ & 0,000155 \\
\hline bta-miR-183 & & & 0,000053 & 0,000005 & 0,000450 & 0,000271 & 0,000250 & 0,000214 \\
\hline bta-miR-184 & & & & & 0,000150 & 0,000083 & 0,000118 & 0,000054 \\
\hline bta-miR-185 & 0,001293 & 0,000201 & 0,001754 & 0,000457 & 0,002006 & 0,000635 & 0,002778 & 0,000759 \\
\hline bta-miR-186 & 0,004965 & 0,002168 & 0,005479 & 0,001305 & 0,013082 & 0,004602 & 0,010151 & 0,004179 \\
\hline bta-miR-187 & 0,000327 & 0,000174 & 0,000326 & 0,000038 & 0,001629 & 0,001768 & 0,002817 & 0,003615 \\
\hline bta-miR-188 & 0,002226 & 0,000984 & 0,002599 & 0,000477 & 0,001968 & 0,000747 & 0,003680 & 0,001019 \\
\hline bta-miR-18a & 0,003453 & 0,000665 & 0,003244 & 0,000208 & 0,007773 & 0,002446 & 0,005297 & 0,002076 \\
\hline bta-miR-18b & 000966 & 0,000488 & 0,000933 & 0,000110 & 0,002835 & 0,001315 & 0,001625 & 0,000587 \\
\hline bta-miR-190a & & & & & 0,000210 & 0,000094 & 0,000078 & 0,000043 \\
\hline bta-miR-190b & 0,000262 & 0,000170 & 0,000175 & 0,000018 & 0,000068 & 0,000040 & 0,000189 & 0,000077 \\
\hline bta-miR-191 & 0,000839 & 0,000305 & 0,000934 & 0,000276 & 0,003141 & 0,001691 & 0,002077 & 0,000637 \\
\hline bta-miR-192 & 0,000122 & 0,000050 & 0,000110 & 0,000043 & 0,000681 & 0,000622 & 0,000984 & 0,001132 \\
\hline bta-miR-193a & & & & & & & & \\
\hline bta-miR-193a-3p & & D & 0,000026 & 0,000008 & 0,000187 & 0,00017 & & \\
\hline bta-miR-193a-5p & 0,002079 & 0,000296 & 0,002175 & 0,000490 & 0,003137 & 0,000699 & 0,003805 & 0,00113 \\
\hline bta-miR-193b & 0,000079 & 0,000039 & & & & & & \\
\hline bta-miR-194 & 0,000347 & 0,000199 & 0,000651 & 0,000067 & 0,001628 & 0,000439 & 0,001130 & 0,000437 \\
\hline bta-miR-195 & $0,025295^{a}$ & 0,006350 & $0,040635^{b}$ & 0,001090 & 0,021443 & 0,008048 & 0,023199 & 0,00088 \\
\hline
\end{tabular}




\begin{tabular}{|c|c|c|c|c|c|c|c|c|}
\hline bta-miR-196a & \multirow{2}{*}{\multicolumn{2}{|c|}{$\begin{array}{l}\text { ND } \\
\text { ND }\end{array}$}} & 0,000136 & 0,000077 & \multicolumn{2}{|c|}{ ND } & \multicolumn{2}{|c|}{ ND } \\
\hline bta-miR-196b & & & \multicolumn{2}{|c|}{ ND } & 0,000113 & 0,000043 & 0,000178 & 0,000224 \\
\hline bta-miR-197 & 0,000380 & 0,000222 & 0,000462 & 0,000053 & 0,003576 & 0,002117 & 0,005054 & 0,005914 \\
\hline bta-miR-199a-3p & 0,000694 & 0,000328 & 0,000870 & 0,000037 & 0,004983 & 0,00253 & 0,003030 & 0,000733 \\
\hline bta-miR-199a-5p & 0,000157 & 0,000102 & 0,000260 & 0,000145 & 0,002657 & 0,002122 & 0,001482 & 0,001379 \\
\hline bta-miR-199b & \multicolumn{2}{|c|}{ ND } & \multicolumn{2}{|c|}{ ND } & 0,000603 & 0,000415 & 0,000411 & 0,000295 \\
\hline bta-miR-199c & 0,001880 & 0,000404 & 0,002181 & 0,000812 & 0,009875 & 0,00601 & 0,007330 & 0,003757 \\
\hline bta-miR-19a & 0,014049 & 0,014613 & 0,009954 & 0,005607 & 0,043488 & 0,025699 & 0,013545 & 0,008152 \\
\hline bta-miR-19b & 0,013371 & 0,013047 & 0,009965 & 0,005004 & 0,044082 & 0,025771 & 0,014395 & 0,008805 \\
\hline bta-miR-200a & \multicolumn{2}{|c|}{ ND } & \multicolumn{2}{|c|}{ ND } & \multicolumn{2}{|c|}{ ND } & \multicolumn{2}{|c|}{ ND } \\
\hline bta-miR-200b & 0,000261 & 0,000268 & 0,000535 & 0,000066 & 0,000349 & 0,000041 & 0,000415 & 0,000113 \\
\hline bta-miR-200c & \multicolumn{2}{|c|}{ ND } & 0,000064 & 0,000034 & 0,000207 & 0,000081 & \multicolumn{2}{|c|}{ ND } \\
\hline bta-miR-202 & 0,116085 & 0,025989 & 0,133426 & 0,005942 & 0,095483 & 0,019924 & 0,127769 & 0,02816 \\
\hline bta-miR-204 & 0,000239 & 0,000016 & 0,000258 & 0,000045 & $0,014959^{a}$ & 0,00459 & $0,006079^{b}$ & 0,00281 \\
\hline bta-miR-205 & 0,000242 & 0,000093 & 0,000239 & 0,000131 & 0,001782 & 0,000535 & \multicolumn{2}{|c|}{ ND } \\
\hline bta-miR-206 & 0,000121 & 0,000018 & 0,000094 & 0,000034 & 0,000379 & 0,000284 & 0,000761 & 0,00102 \\
\hline bta-miR-208a & \multicolumn{2}{|c|}{ ND } & \multicolumn{2}{|c|}{ ND } & \multicolumn{2}{|c|}{ ND } & \multicolumn{2}{|c|}{ ND } \\
\hline bta-miR-208b & \multicolumn{2}{|c|}{ ND } & \multicolumn{2}{|c|}{ ND } & \multicolumn{2}{|c|}{ ND } & \multicolumn{2}{|c|}{ ND } \\
\hline bta-miR-20a & 0,048405 & 0,013546 & 0,054338 & 0,001410 & 0,071453 & 0,030666 & 0,056360 & 0,024557 \\
\hline bta-miR-20b & 0,020868 & 0,005423 & 0,024130 & 0,001658 & 0,029010 & 0,009279 & 0,021776 & 0,006271 \\
\hline bta-miR-210 & 0,023072 & 0,006785 & 0,032484 & 0,006847 & $0,009398^{a}$ & 0,001824 & $0,031734^{b}$ & 0,008556 \\
\hline bta-miR-211 & 0,000433 & 0,000144 & 0,000354 & 0,000120 & $0,017770^{a}$ & 0,002527 & $0,007352^{b}$ & 0,003023 \\
\hline bta-miR-212 & \multicolumn{2}{|c|}{ ND } & & & & & $\mathrm{NL}$ & \\
\hline bta-miR-21-3p & & $D$ & & & & & $\mathrm{NL}$ & \\
\hline bta-miR-214 & 0,000111 & 0,000004 & 0,000100 & 0,000040 & 0,002882 & 0,004029 & 0,005096 & 0,007676 \\
\hline bta-miR-215 & $0,000096^{a}$ & 0,000047 & $0,000187^{b}$ & 0,000032 & 0,000596 & 0,000513 & 0,000492 & 0,000202 \\
\hline bta-miR-21-5p & 0,000724 & 0,000325 & 0,000811 & 0,000334 & 0,014978 & 0,012552 & 0,005749 & 0,002444 \\
\hline bta-miR-216a & & & & & 0,000261 & 0,000306 & $N D$ & \\
\hline bta-miR-216b & & & & & & & $\mathrm{NL}$ & \\
\hline bta-miR-217 & & & & & & & $\mathrm{NL}$ & \\
\hline bta-miR-218 & & & 0,000091 & 0,000012 & 0,000094 & 0,000032 & 0,000090 & 0,000052 \\
\hline bta-miR-219 & 0,000194 & 0,000059 & 0,000109 & 0,000012 & 0,000508 & 0,000209 & $\mathrm{NL}$ & \\
\hline bta-miR-219-3p & & D & & & & & NL & \\
\hline bta-miR-219-5p & & & & & & & ND & \\
\hline bta-miR-221 & 0,006385 & 0,001000 & 0,004819 & 0,001555 & $0,041849^{a}$ & 0,006376 & $0,023096^{b}$ & 0,007627 \\
\hline bta-miR-222 & 0,009604 & 0,000743 & 0,008951 & 0,003447 & 0,063750 & 0,018768 & 0,038462 & 0,012331 \\
\hline bta-miR-223 & & & & & & & 0,000084 & 0,000064 \\
\hline bta-miR-22-3p & & & & & & & $N D$ & \\
\hline bta-miR-224 & 0,000315 & 0,000159 & 0,000439 & 0,000103 & $0,000367^{a}$ & 0,000050 & $0,000174^{b}$ & 0,000095 \\
\hline bta-miR-22-5p & 0,000923 & 0,000345 & 0,000828 & 0,000153 & 0,003422 & 0,001217 & 0,002157 & 0,000128 \\
\hline bta-miR-23a & 0,005771 & 0,001826 & 0,004701 & 0,000509 & $0,061274^{a}$ & 0,019386 & $0,028383^{b}$ & 0,006599 \\
\hline bta-miR-23b-3p & 0,000183 & 0,000073 & 0,000163 & 0,000034 & 0,011463 & 0,005412 & 0,004873 & 0,001617 \\
\hline bta-miR-23b-5p & & & & & & & ND & \\
\hline bta-miR-24 & & & & & & & ND & \\
\hline
\end{tabular}




\begin{tabular}{|c|c|c|c|c|c|c|c|c|}
\hline bta-miR-24-3p & 0,009130 & 0,001446 & 0,012130 & 0,001903 & 0,068305 & 0,026626 & 0,037743 & 0,010164 \\
\hline bta-miR-25 & 0,028558 & 0,004724 & 0,034104 & 0,005086 & 0,038250 & 0,004359 & 0,046187 & 0,013802 \\
\hline bta-miR-26a & 0,010231 & 0,003484 & 0,015108 & 0,003161 & 0,029323 & 0,010772 & 0,014725 & 0,004596 \\
\hline bta-miR-26b & 0,003799 & 0,000731 & 0,004517 & 0,000341 & 0,006905 & 0,001835 & 0,004261 & 0,001666 \\
\hline bta-miR-26c & \multicolumn{2}{|c|}{ ND } & \multicolumn{2}{|c|}{ ND } & \multicolumn{2}{|c|}{ ND } & \multicolumn{2}{|c|}{ ND } \\
\hline bta-miR-27a-3p & 0,014423 & 0,002385 & 0,014555 & 0,004945 & 0,054793 & 0,020766 & 0,039068 & 0,012118 \\
\hline bta-miR-27a-5p & \multicolumn{2}{|c|}{ ND } & \multicolumn{2}{|c|}{ ND } & \multicolumn{2}{|c|}{ ND } & 0,000403 & 0,000611 \\
\hline bta-miR-27b & 0,002027 & 0,000279 & 0,001635 & 0,000138 & 0,051125 & 0,025152 & 0,024021 & 0,008453 \\
\hline bta-miR-28 & 0,000589 & 0,000235 & 0,000601 & 0,000100 & 0,003086 & 0,001662 & 0,001724 & 0,000658 \\
\hline bta-miR-296-3p & 0,000127 & 0,000082 & & & 0,001366 & 0,001347 & 0,002630 & 0,003912 \\
\hline bta-miR-296-5p & 0,000265 & 0,000058 & 0,000329 & 0,000073 & 0,001493 & 0,001414 & 0,001909 & 0,002473 \\
\hline bta-miR-299 & \multicolumn{2}{|c|}{ ND } & \multicolumn{2}{|c|}{ ND } & \multicolumn{2}{|c|}{ ND } & \multicolumn{2}{|c|}{ ND } \\
\hline bta-miR-29a & 0,024983 & 0,006684 & 0,034426 & 0,009092 & 0,066961 & 0,045698 & 0,041214 & 0,012196 \\
\hline bta-miR-29b & 0,001030 & 0,000324 & 0,000886 & 0,000324 & 0,013341 & 0,010828 & 0,004101 & 0,001594 \\
\hline bta-miR-29c & 0,024821 & 0,007540 & 0,032822 & 0,009911 & 0,050108 & 0,02823 & 0,036279 & 0,010417 \\
\hline bta-miR-29d-3p & 0,001459 & 0,000692 & 0,002699 & 0,000760 & 0,002280 & 0,00088 & 0,002102 & 0,000964 \\
\hline bta-miR-29d-5p & \multicolumn{2}{|c|}{ ND } & 0,000040 & 0,000024 & \multicolumn{2}{|c|}{ ND } & \multicolumn{2}{|c|}{ ND } \\
\hline bta-miR-29e & 0,000143 & 0,000100 & 0,000350 & 0,000101 & 0,002180 & 0,001573 & 0,000861 & 0,000369 \\
\hline bta-miR-301a & \multicolumn{2}{|c|}{ ND } & \multicolumn{2}{|c|}{ ND } & 0,000362 & 0,0002 & 0,000204 & 0,000141 \\
\hline bta-miR-301b & \multicolumn{2}{|c|}{ ND } & \multicolumn{2}{|c|}{ ND } & $0,000406^{a}$ & 0,000207 & $0,000070^{b}$ & 0,000027 \\
\hline bta-miR-302a & \multicolumn{2}{|c|}{ ND } & \multicolumn{2}{|c|}{ ND } & 0,000192 & 0,000085 & 0,000122 & 0,000049 \\
\hline bta-miR-302b & \multicolumn{2}{|c|}{ ND } & \multicolumn{2}{|c|}{ ND } & 0,000050 & 0,0000142 & \multicolumn{2}{|c|}{ ND } \\
\hline bta-miR-302c & & & & & 0,000275 & 0,000164 & $\mathrm{~N}$ & \\
\hline bta-miR-302d & & & & & $0,000689^{a}$ & 0,000222 & $0,000306^{b}$ & 0,000044 \\
\hline bta-miR-3064 & & $D$ & & & & & $\mathrm{~N}$ & \\
\hline bta-miR-30a-5p & 0,004971 & 0,000909 & 0,006513 & 0,000841 & 0,019116 & 0,009104 & 0,012977 & 0,005532 \\
\hline bta-miR-30b-3p & & D & & & & & $\mathrm{N}$ & \\
\hline bta-miR-30b-5p & 0,001467 & 0,001065 & 0,002508 & 0,000412 & 0,006615 & 0,003144 & 0,003619 & 0,001396 \\
\hline bta-miR-30c & 0,000634 & 0,000065 & 0,000755 & 0,000111 & 0,006378 & 0,002703 & 0,002903 & 0,00144 \\
\hline bta-miR-30d & 0,004969 & 0,000745 & 0,006192 & 0,000621 & 0,018357 & 0,009571 & 0,012613 & 0,005141 \\
\hline bta-miR-30e-5p & 0,005299 & 0,002080 & 0,006806 & 0,000745 & 0,019446 & 0,011559 & 0,013916 & 0,005268 \\
\hline bta-miR-30f & & D & 0,000069 & 0,000024 & 0,002270 & 0,001057 & 0,001196 & 0,000579 \\
\hline bta-miR-31 & 0,008219 & 0,004434 & 0,011415 & 0,004280 & 0,016802 & 0,006445 & 0,009713 & 0,003831 \\
\hline bta-miR-32 & & D & & & & & $N$ & \\
\hline bta-miR-320a & 0,022278 & 0,001819 & 0,024667 & 0,003147 & 0,032737 & 0,019571 & 0,035846 & 0,003454 \\
\hline bta-miR-320b & 0,000769 & 0,000184 & 0,000812 & 0,000122 & 0,002013 & 0,002167 & 0,003766 & 0,003664 \\
\hline bta-miR-323 & 9,082775 & 2,864347 & 4,752929 & 0,806267 & 7,631288 & 3,338651 & 5,852869 & 1,246201 \\
\hline bta-miR-324 & 0,000497 & 0,000075 & 0,000501 & 0,000118 & 0,003976 & 0,004506 & 0,001332 & 0,000827 \\
\hline bta-miR-326 & 0,001404 & 0,002102 & 0,000324 & 0,000261 & 0,003331 & 0,005128 & 0,009984 & 0,016263 \\
\hline bta-miR-328 & 0,000230 & 0,000057 & 0,000191 & 0,000013 & & & $\mathrm{~N}$ & \\
\hline bta-miR-329a & & & & & & & $\mathrm{N}$ & \\
\hline bta-miR-329b & & D & & & & & $N$ & \\
\hline bta-miR-330 & 0,000051 & 0,000006 & 0,000040 & 0,000007 & 0,000840 & 0,001152 & $\mathrm{~N}$ & \\
\hline bta-miR-331-3p & 0,000202 & 0,000235 & 0,000121 & 0,000074 & 0,001698 & 0,001029 & 0,000367 & $0,00020 €$ \\
\hline
\end{tabular}




\begin{tabular}{|c|c|c|c|c|c|c|c|c|}
\hline bta-miR-331-5p & 0,000659 & 0,000143 & 0,000516 & 0,000213 & 0,001501 & 0,001214 & 0,002861 & 0,003595 \\
\hline bta-miR-335 & 0,000510 & 0,000178 & 0,000658 & 0,000089 & 0,000397 & 0,000254 & 0,000642 & 0,000414 \\
\hline bta-miR-338 & 0,000328 & 0,000084 & 0,000458 & 0,000126 & 0,000683 & 0,000123 & \multicolumn{2}{|c|}{ ND } \\
\hline bta-miR-339a & 0,000089 & 0,000018 & 0,000094 & 0,000022 & 0,003510 & 0,004448 & 0,007320 & 0,01157 \\
\hline bta-miR-339b & \multicolumn{2}{|c|}{ ND } & 0,000221 & 0,000031 & 0,004727 & 0,004061 & 0,005075 & 0,007368 \\
\hline bta-miR-33a & \multicolumn{2}{|c|}{ ND } & 0,000040 & 0,000008 & 0,000930 & 0,000911 & \multicolumn{2}{|c|}{ ND } \\
\hline bta-miR-33b & \multicolumn{2}{|c|}{ ND } & \multicolumn{2}{|c|}{ ND } & 0,000145 & 0,000051 & \\
\hline bta-miR-340 & \multicolumn{2}{|c|}{ ND } & \multicolumn{2}{|c|}{ ND } & \multicolumn{2}{|c|}{ ND } & & \\
\hline bta-miR-342 & \multicolumn{2}{|c|}{ ND } & \multicolumn{2}{|c|}{ ND } & \multicolumn{2}{|c|}{ ND } & 0,000569 & 0,000477 \\
\hline bta-miR-345-3p & 0,000680 & 0,000316 & 0,000735 & 0,000076 & 0,001152 & 0,00102 & 0,002327 & 0,002025 \\
\hline bta-miR-345-5p & 0,000097 & 0,000061 & \multicolumn{2}{|c|}{ ND } & 0,000898 & 0,00087 & 0,001143 & 0,00167 \\
\hline bta-miR-346 & $0,000084^{a}$ & 0,000010 & $0,000178^{b}$ & 0,000019 & 0,006478 & 0,010321 & 0,017600 & 0,028238 \\
\hline bta-miR-34a & 0,000511 & 0,000048 & 0,000353 & 0,000185 & $0,003657^{a}$ & 0,001235 & $0,001448^{b}$ & 0,000769 \\
\hline bta-miR-34b & 0,000075 & 0,000045 & 0,000111 & 0,000015 & 0,001200 & 0,000434 & 0,000617 & 0,000319 \\
\hline bta-miR-34c & 0,000148 & 0,000125 & 0,000071 & 0,000069 & 0,001148 & 0,00037 & 0,000731 & 0,000405 \\
\hline bta-miR-361 & 0,000241 & 0,000185 & 0,000298 & 0,000094 & 0,001116 & 0,000413 & \multicolumn{2}{|c|}{ ND } \\
\hline bta-miR-362-3p & 0,000463 & 0,000128 & 0,000643 & 0,000170 & 0,001194 & 0,000964 & 0,001064 & 0,000785 \\
\hline bta-miR-362-5p & 0,000058 & 0,000019 & 0,000076 & 0,000036 & 0,000283 & 0,000061 & 0,000185 & 0,000069 \\
\hline bta-miR-363 & \multicolumn{2}{|c|}{ ND } & \multicolumn{2}{|c|}{ ND } & \multicolumn{2}{|c|}{ ND } & 0,000242 & 0,000188 \\
\hline bta-miR-365-3p & 0,001346 & 0,000540 & 0,002239 & 0,000463 & 0,009000 & 0,003265 & 0,004484 & 0,001626 \\
\hline bta-miR-365-5p & 0,003855 & 0,001782 & 0,003343 & 0,000697 & 0,013456 & 0,018865 & 0,034910 & 0,042547 \\
\hline bta-miR-367 & \multicolumn{2}{|c|}{ ND } & \multicolumn{2}{|c|}{ ND } & \multicolumn{2}{|c|}{ ND } & \multicolumn{2}{|c|}{ ND } \\
\hline bta-miR-369-3p & 0,000963 & 0,000306 & 0,000615 & 0,000051 & 0,000803 & 0,000312 & 0,000475 & 0,000066 \\
\hline bta-miR-369-5p & & D & $N$ & & & & NL & \\
\hline bta-miR-370 & & $D$ & 0,000099 & 0,000080 & 0,000784 & 0,00119 & 0,002007 & 0,003072 \\
\hline bta-miR-371 & & D & 0,000023 & 0,000004 & 0,024835 & 0,013441 & 0,011596 & 0,004983 \\
\hline bta-miR-374a & 0,000616 & 0,000259 & 0,000748 & 0,000075 & 0,001311 & 0,000408 & 0,000848 & 0,000323 \\
\hline bta-miR-374b & $0,000768^{a}$ & 0,000343 & $0,001416^{b}$ & 0,000126 & 0,002067 & 0,000901 & 0,001053 & 0,000174 \\
\hline bta-miR-375 & 0,000241 & 0,000043 & 0,000198 & 0,000055 & 0,000231 & 0,000078 & 0,000389 & 0,000197 \\
\hline bta-miR-376a & & D & $N$ & & & & NL & \\
\hline bta-miR-376b & & D & $\mathrm{N}$ & & & & NL & \\
\hline bta-miR-376c & & D & $\mathrm{N}$ & & & & ND & \\
\hline bta-miR-376d & & D & $N$ & & & & $\mathrm{NL}$ & \\
\hline bta-miR-376e & & D & $N$ & & & & $\mathrm{NL}$ & \\
\hline bta-miR-377 & & D & $N$ & & & & NL & \\
\hline bta-miR-378 & 0,000640 & 0,000324 & 0,000588 & 0,000170 & 0,011191 & 0,005357 & 0,007110 & 0,001811 \\
\hline bta-miR-378b & 0,000513 & 0,000280 & 0,000503 & 0,000204 & 0,011009 & 0,00467 & 0,006271 & 0,001528 \\
\hline bta-miR-378c & 0,000067 & 0,000034 & 0,000068 & 0,000032 & 0,001235 & 0,00052 & 0,000726 & 0,00035 \\
\hline bta-miR-378d & & D & $N$ & & 0,000544 & 0,00054 & 0,000676 & 0,000867 \\
\hline bta-miR-379 & & D & $N$ & & & & ND & \\
\hline bta-miR-380-3p & 0,000639 & 0,000136 & 0,000326 & 0,000162 & & & ND & \\
\hline bta-miR-380-5p & 0,000076 & 0,000040 & $N$ & & & & NL & \\
\hline bta-miR-381 & & D & $N$ & & & & 0,000638 & 0,000961 \\
\hline bta-miR-382 & 0,000208 & 0,000071 & 0,000123 & 0,000039 & 0,000426 & 0,000202 & 0,000222 & 0,000228 \\
\hline
\end{tabular}




\begin{tabular}{|c|c|c|c|c|c|c|c|c|}
\hline bta-miR-383 & \multicolumn{2}{|c|}{ ND } & 0,000046 & 0,000008 & \multicolumn{2}{|c|}{ ND } & 0,000400 & 0,000525 \\
\hline bta-miR-409a & \multicolumn{2}{|c|}{ ND } & \multicolumn{2}{|c|}{ ND } & \multicolumn{2}{|c|}{ ND } & \multicolumn{2}{|c|}{ ND } \\
\hline bta-miR-409b & \multicolumn{2}{|c|}{ ND } & \multicolumn{2}{|c|}{ ND } & \multicolumn{2}{|c|}{ ND } & \multicolumn{2}{|c|}{ ND } \\
\hline bta-miR-410 & 0,000074 & 0,000043 & \multicolumn{2}{|c|}{ ND } & \multicolumn{2}{|c|}{ ND } & 0,000351 & 0,000544 \\
\hline bta-miR-411a & 0,000072 & 0,000017 & 0,000046 & 0,000016 & 0,000141 & 0,000061 & \multicolumn{2}{|c|}{ ND } \\
\hline bta-miR-411b & \multicolumn{2}{|c|}{ ND } & \multicolumn{2}{|c|}{ ND } & \multicolumn{2}{|c|}{0,0000301} & & \\
\hline bta-miR-411c-3p & \multicolumn{2}{|c|}{ ND } & \multicolumn{2}{|c|}{ ND } & \multicolumn{2}{|c|}{ ND } & \multicolumn{2}{|c|}{ ND } \\
\hline bta-miR-411c-5p & \multicolumn{2}{|c|}{ ND } & \multicolumn{2}{|c|}{ ND } & \multicolumn{2}{|c|}{ ND } & & \\
\hline bta-miR-412 & & & & & & & & \\
\hline bta-miR-421 & 0,004513 & 0,002615 & 0,001426 & 0,000844 & 0,003836 & 0,004168 & 0,001555 & 0,000975 \\
\hline bta-miR-423-3p & 0,000360 & 0,000097 & 0,000497 & 0,000128 & 0,002852 & 0,001542 & 0,002220 & 0,001279 \\
\hline bta-miR-423-5p & 0,003704 & 0,000759 & 0,003262 & 0,000235 & 0,004618 & 0,001087 & 0,005219 & 0,00074 \\
\hline bta-miR-424-3p & & & & & 0,000219 & 0,00028 & 0,000358 & 0,000495 \\
\hline bta-miR-424-5p & 0,004172 & 0,000137 & 0,004522 & 0,001261 & 0,009992 & 0,004516 & 0,008218 & 0,001369 \\
\hline bta-miR-425-3p & 0,001159 & 0,000028 & 0,001188 & 0,000413 & 0,009303 & 0,006346 & 0,007482 & 0,008447 \\
\hline bta-miR-425-5p & 0,001134 & 0,000276 & 0,002279 & 0,000246 & 0,002555 & 0,000684 & 0,002212 & 0,000063 \\
\hline bta-miR-429 & $0,000490^{\circ}$ & 0,000120 & 0,000235 & 0,000095 & 0,000492 & 0,000087 & 0,000473 & 0,000191 \\
\hline bta-miR-431 & & & & & & & 0,001753 & 0,002682 \\
\hline bta-miR-432 & 0,000162 & 0,000056 & 0,000169 & 0,000050 & 0,000430 & 0,000568 & 0,001105 & 0,001521 \\
\hline bta-miR-433 & $0,000579^{\circ}$ & 0,000087 & 0,000307 & 0,000045 & 0,001180 & 0,001294 & 0,001977 & 0,002344 \\
\hline bta-miR-448 & & & & & & & & \\
\hline bta-miR-449a & & & 0,000059 & 0,000018 & $0,001117^{a}$ & 0,000352 & $0,000450^{b}$ & 0,000149 \\
\hline bta-miR-449b & & & & & & & & \\
\hline bta-miR-449c & & & & & 0,000223 & 0,000273 & 0,000579 & 0,000905 \\
\hline bta-miR-449d & 0,000157 & 0,000092 & 0,000093 & 0,000027 & 0,002146 & 0,003203 & 0,005178 & 0,007905 \\
\hline bta-miR-450a & & & & & $0,000330^{a}$ & 0,0000992 & $0,000133^{b}$ & 0,000030 \\
\hline bta-miR-450b & & & & & 0,000337 & 0,000121 & 0,000142 & 0,000078 \\
\hline bta-miR-451 & 0,001589 & 0,000659 & 0,000851 & 0,000187 & 0,000908 & 0,000283 & 0,000790 & 0,000366 \\
\hline bta-miR-452 & & & 0,000040 & 0,000008 & & & & \\
\hline bta-miR-4523 & 0,002333 & 0,003905 & 0,001926 & 0,003215 & 0,000530 & 0,000696 & & \\
\hline bta-miR-453 & 0,000092 & 0,000033 & 0,000072 & 0,000020 & 0,000242 & 0,000145 & 0,000362 & 0,000449 \\
\hline bta-miR-454 & & & & & $0,000544^{a}$ & 0,000039 & $0,000240^{b}$ & 0,000107 \\
\hline bta-miR-455-3p & & & & & 0,000106 & 0,000063 & 0,000091 & 0,000051 \\
\hline bta-miR-455-5p & & & 0,000036 & 0,000013 & 0,000791 & 0,000193 & 0,000669 & 0,000222 \\
\hline bta-miR-483 & & & 0,000106 & 0,000063 & 0,000444 & 0,000649 & & \\
\hline bta-miR-484 & 0,000361 & 0,000268 & 0,000476 & 0,000175 & 0,001983 & 0,000979 & 0,001164 & 0,000627 \\
\hline bta-miR-485 & & & & & & & & \\
\hline bta-miR-486 & 0,000702 & 0,000126 & 0,000444 & 0,000199 & 0,007489 & 0,008203 & & \\
\hline bta-miR-487a & & & & & & & & \\
\hline bta-miR-487b & & & & & 0,000075 & 0,000052 & & \\
\hline bta-miR-488 & & & & & & & & \\
\hline bta-miR-489 & 0,000121 & 0,000044 & 0,000058 & 0,000022 & 0,000272 & 0,000274 & 0,000283 & 0,000365 \\
\hline bta-miR-490 & & & & & & & 0,001785 & 0,002902 \\
\hline bta-miR-491 & 0,000193 & 0,000097 & 0,000414 & 0,000052 & & & 0,000520 & 0,000302 \\
\hline
\end{tabular}




\begin{tabular}{|c|c|c|c|c|c|c|c|c|}
\hline bta-miR-493 & 0,000088 & 0,000078 & \multicolumn{2}{|c|}{ ND } & 0,003208 & 0,004836 & 0,006133 & 0,009587 \\
\hline bta-miR-494 & 0,032518 & 0,020469 & 0,023311 & 0,008754 & 0,557093 & 0,52174 & 0,460564 & 0,36218 \\
\hline bta-miR-495 & 0,000129 & 0,000106 & \multicolumn{2}{|c|}{ ND } & \multicolumn{2}{|c|}{ ND } & \multicolumn{2}{|c|}{ ND } \\
\hline bta-miR-496 & \multicolumn{2}{|c|}{ ND } & \multicolumn{2}{|c|}{ ND } & \multicolumn{2}{|c|}{ ND } & \multicolumn{2}{|c|}{ ND } \\
\hline bta-miR-497 & 0,007951 & 0,002013 & 0,008302 & 0,002341 & 0,007368 & 0,002879 & 0,010851 & 0,002837 \\
\hline bta-miR-499 & 0,000093 & 0,000027 & 0,000134 & 0,000056 & $\mathrm{~N}$ & & 0,000203 & 0,000126 \\
\hline bta-miR-500 & 0,001202 & 0,000408 & 0,001818 & 0,000634 & 0,001387 & 0,000086 & 0,001216 & 0,000158 \\
\hline bta-miR-502a & \multicolumn{2}{|c|}{ ND } & 0,000043 & 0,000010 & 0,000174 & 0,000135 & 0,000247 & 0,000312 \\
\hline bta-miR-502b & 0,000154 & 0,000061 & 0,000121 & 0,000050 & 0,000661 & 0,000166 & 0,000521 & 0,000291 \\
\hline bta-miR-503-3p & \multicolumn{2}{|c|}{ ND } & 0,000598 & 0,000133 & 0,002844 & 0,003321 & 0,004124 & 0,005131 \\
\hline bta-miR-503-5p & 0,000512 & 0,000100 & 0,000291 & 0,000280 & 0,002326 & 0,000793 & 0,001704 & 0,000523 \\
\hline bta-miR-504 & \multicolumn{2}{|c|}{ ND } & \multicolumn{2}{|c|}{ ND } & \multicolumn{2}{|c|}{ ND } & 0,000830 & 0,001249 \\
\hline bta-miR-505 & 0,000255 & 0,000105 & 0,000179 & 0,000060 & \multicolumn{2}{|c|}{ ND } & \multicolumn{2}{|c|}{ ND } \\
\hline bta-miR-532 & 0,001106 & 0,000179 & 0,001248 & 0,000238 & 0,001491 & 0,000428 & \multicolumn{2}{|c|}{ ND } \\
\hline bta-miR-539 & \multicolumn{2}{|c|}{ ND } & \multicolumn{2}{|c|}{ ND } & \multicolumn{2}{|c|}{ ND } & \multicolumn{2}{|c|}{ ND } \\
\hline bta-miR-541 & 0,000694 & 0,000170 & 0,000437 & 0,000207 & 0,001740 & 0,001225 & 0,003133 & 0,003817 \\
\hline bta-miR-542-5p & 0,000085 & 0,000031 & 0,000041 & 0,000015 & 0,000162 & 0,000125 & 0,000176 & 0,000113 \\
\hline bta-miR-543 & \multicolumn{2}{|c|}{ ND } & \multicolumn{2}{|c|}{ ND } & \multicolumn{2}{|c|}{ ND } & $\mathrm{NI}$ & \\
\hline bta-miR-544a & & & $\mathrm{N}$ & & $N$ & & NI & \\
\hline bta-miR-544b & & & $\mathrm{N}$ & & $\mathrm{N}$ & & $\mathrm{NI}$ & \\
\hline bta-miR-545-3p & 0,000192 & 0,000060 & 0,000200 & 0,000167 & 0,000365 & 0,000168 & 0,000268 & 0,000203 \\
\hline bta-miR-545-5p & & & 0,000157 & 0,000058 & 0,000462 & 0,000244 & 0,000361 & 0,000115 \\
\hline bta-miR-551a & & & $\mathrm{N}$ & & $\mathrm{N}$ & & $\mathrm{NI}$ & \\
\hline bta-miR-551b & & & 0,000058 & 0,000018 & $N$ & & 0,000154 & 0,000041 \\
\hline bta-miR-562 & & & $N$ & & $\mathrm{~N}$ & & $\mathrm{NI}$ & \\
\hline bta-miR-568 & & & $\mathrm{N}$ & & $\mathrm{N}$ & & $\mathrm{NI}$ & \\
\hline bta-miR-574 & 0,044429 & 0,009295 & 0,028481 & 0,006449 & 0,247200 & 0,380251 & 0,504979 & 0,666354 \\
\hline bta-miR-582 & & & $\mathrm{N}$ & & $\mathrm{N}$ & & $\mathrm{NI}$ & \\
\hline bta-miR-584 & & & 0,000222 & 0,000031 & 0,001366 & 0,001412 & 0,002584 & 0,003868 \\
\hline bta-miR-592 & 0,000138 & 0,000075 & 0,000114 & 0,000059 & 0,000192 & 0,000115 & $\mathrm{NI}$ & \\
\hline bta-miR-599 & & & $\mathrm{N}$ & & $\mathrm{N}$ & & $\mathrm{NI}$ & \\
\hline bta-miR-615 & & & $\mathrm{N}$ & & $N$ & & NI & \\
\hline bta-miR-628 & & & $\mathrm{N}$ & & 0,000076 & 0,000024 & $\mathrm{NI}$ & \\
\hline bta-miR-631 & 1,406104 & 0,473802 & 0,762666 & 0,104904 & 1,058150 & 0,463734 & 1,037000 & 0,127075 \\
\hline bta-miR-652 & 0,001080 & 0,000335 & 0,001497 & 0,000046 & 0,002576 & 0,000851 & $\mathrm{NI}$ & \\
\hline bta-miR-653 & & & $\mathrm{N}$ & & $\mathrm{N}$ & & $\mathrm{NI}$ & \\
\hline bta-miR-654 & & & $\mathrm{N}$ & & 0,000206 & 0,000254 & $\mathrm{NL}$ & \\
\hline bta-miR-655 & & D & $\mathrm{N}$ & & $\mathrm{N}$ & & $\mathrm{NI}$ & \\
\hline bta-miR-656 & $0,000176^{a}$ & 0,000053 & $0,000086^{b}$ & 0,000015 & 0,000154 & 0,000017 & $\mathrm{NI}$ & \\
\hline bta-miR-658 & 0,001250 & 0,000236 & 0,001407 & 0,000186 & 0,003809 & 0,001925 & 0,003668 & 0,002494 \\
\hline bta-miR-660 & 0,001838 & 0,000346 & 0,002549 & 0,000773 & 0,003635 & 0,00097 & 0,003962 & 0,000664 \\
\hline bta-miR-664a & 0,001068 & 0,000766 & 0,001291 & 0,000470 & 0,003545 & 0,004387 & 0,009808 & 0,013303 \\
\hline bta-miR-664b & $0,000053^{a}$ & 0,000028 & $0,000145^{b}$ & 0,000027 & 0,000415 & 0,000203 & $\mathrm{NI}$ & \\
\hline bta-miR-665 & 0,000340 & 0,000072 & 0,000320 & 0,000088 & 0,006443 & 0,009227 & $\mathrm{NI}$ & \\
\hline
\end{tabular}




\begin{tabular}{|c|c|c|c|c|c|c|c|c|}
\hline bta-miR-669 & 0,002022 & 0,000700 & 0,001736 & 0,000525 & 0,040075 & 0,063603 & 0,123774 & 0,179924 \\
\hline bta-miR-670 & \multicolumn{2}{|c|}{ ND } & \multicolumn{2}{|c|}{ ND } & \multicolumn{2}{|c|}{ ND } & \multicolumn{2}{|c|}{ ND } \\
\hline bta-miR-671 & 0,000081 & 0,000037 & 0,000089 & 0,000035 & 0,000267 & 0,000243 & 0,000484 & 0,000381 \\
\hline bta-miR-677 & 0,000404 & 0,000363 & 0,000399 & 0,000327 & 0,001363 & 0,000477 & 0,000880 & 0,00073 \\
\hline bta-miR-7 & \multicolumn{2}{|c|}{ ND } & \multicolumn{2}{|c|}{ ND } & 0,000410 & 0,000148 & \multicolumn{2}{|c|}{ ND } \\
\hline bta-miR-708 & 0,001513 & 0,000467 & 0,001899 & 0,000355 & 0,005422 & 0,000373 & 0,003915 & 0,001083 \\
\hline bta-miR-744 & \multicolumn{2}{|c|}{ ND } & 0,000066 & 0,000017 & 0,000323 & 0,000368 & \multicolumn{2}{|c|}{ ND } \\
\hline bta-miR-758 & \multicolumn{2}{|c|}{ ND } & \multicolumn{2}{|c|}{ ND } & \multicolumn{2}{|c|}{ ND } & \multicolumn{2}{|c|}{ ND } \\
\hline bta-miR-759 & \multicolumn{2}{|c|}{ ND } & \multicolumn{2}{|c|}{ ND } & \multicolumn{2}{|c|}{ ND } & \multicolumn{2}{|c|}{ ND } \\
\hline bta-miR-760-3p & 0,000961 & 0,000215 & 0,001119 & 0,000238 & 0,003292 & 0,003807 & 0,007002 & 0,008154 \\
\hline bta-miR-760-5p & 0,000195 & 0,000074 & 0,000266 & 0,000061 & 0,002782 & 0,0042 & 0,004914 & 0,007017 \\
\hline bta-miR-761 & \multicolumn{2}{|c|}{ ND } & \multicolumn{2}{|c|}{ ND } & \multicolumn{2}{|c|}{ ND } & \multicolumn{2}{|c|}{ ND } \\
\hline bta-miR-763 & 0,000116 & 0,000034 & & & 0,000887 & 0,001424 & 0,002162 & 0,003389 \\
\hline bta-miR-764 & \multicolumn{2}{|c|}{ ND } & \multicolumn{2}{|c|}{ ND } & \multicolumn{2}{|c|}{ ND } & \multicolumn{2}{|c|}{ ND } \\
\hline bta-miR-767 & 0,000174 & 0,000079 & 0,000093 & 0,000026 & & & $\mathrm{~N}$ & \\
\hline bta-miR-769 & \multicolumn{2}{|c|}{ ND } & \multicolumn{2}{|c|}{ ND } & \multicolumn{2}{|c|}{ ND } & $\mathrm{N}$ & \\
\hline bta-miR-873 & & & & & & & $\mathrm{N}$ & \\
\hline bta-miR-874 & 0,000450 & 0,000224 & 0,000552 & 0,000382 & & & $\mathrm{~N}$ & \\
\hline bta-miR-875 & & & & & & & $\mathrm{N}$ & \\
\hline bta-miR-876 & & & & & & & $\mathrm{N}$ & \\
\hline bta-miR-877 & 0,001561 & 0,000629 & 0,001642 & 0,000100 & 0,006012 & 0,006312 & 0,012174 & 0,013763 \\
\hline bta-miR-885 & 0,000117 & 0,000063 & & & 0,000835 & 0,000915 & 0,001343 & 0,00199 \\
\hline bta-miR-92a & 0,048486 & 0,004943 & 0,050891 & 0,005469 & 0,075874 & 0,005324 & 0,078715 & 0,027699 \\
\hline bta-miR-92b & 0,002946 & 0,001026 & 0,003188 & 0,000363 & 0,025257 & 0,013078 & 0,025097 & 0,026586 \\
\hline bta-miR-93 & 0,012252 & 0,001952 & 0,014998 & 0,000342 & 0,020580 & 0,00645 & 0,015150 & 0,003157 \\
\hline bta-miR-935 & 0,000133 & 0,000067 & 0,000166 & 0,000094 & 0,000578 & 0,000599 & 0,000790 & 0,00088 \\
\hline bta-miR-9-3p & & & & & & & $\mathrm{N}$ & \\
\hline bta-miR-940 & 0,005495 & 0,002092 & 0,005487 & 0,001396 & 0,039957 & 0,028503 & 0,034291 & 0,026895 \\
\hline bta-miR-95 & & & & & & & 0,000108 & 0,000079 \\
\hline bta-miR-9-5p & & & 0,000068 & 0,000030 & 0,000354 & 0,000134 & 0,000195 & 0,000089 \\
\hline bta-miR-96 & & & 0,000272 & 0,000205 & $0,001223^{a}$ & 0,000054 & $0,000381^{b}$ & 0,000229 \\
\hline bta-miR-98 & & & 0,000150 & 0,000143 & $0,001075^{a}$ & 0,000236 & $0,000314^{b}$ & 0,000095 \\
\hline bta-miR-99a-3p & 0,000178 & 0,000103 & 0,000178 & 0,000161 & 0,000390 & 0,000086 & 0,000609 & 0,000245 \\
\hline bta-miR-99a-5p & 0,006383 & 0,001945 & 0,007911 & 0,000052 & 0,012229 & 0,003421 & 0,009177 & 0,001331 \\
\hline
\end{tabular}

$\mathrm{DP}=$ Desvio padrão

$\mathrm{ND}=$ Não determinado

Letras diferentes indicam diferença significante para $p \leq 0,05$ 


\section{APÊNDICE B - Artigo submetido na Reproductive Sciences}

Title: Antioxidant responses and deregulation of epigenetic writers and erasers link oxidative stress and DNA methylation in bovine blastocysts

Authors: Monalisa M. Bomfim¹; Gabriella M. Andrade ${ }^{1}$; Maite del Collado ${ }^{1}$; Juliano R. Sangalli ${ }^{1}$; Patrícia K. Fontes ${ }^{2}$; Marcelo F. G. Nogueira ${ }^{3}$; Flávio V. Meirelles ${ }^{1}$; Juliano C. da Silveira ${ }^{1}$; Felipe Perecin ${ }^{1 *}$

${ }^{1}$ Department of Veterinary Medicine, Faculty of Animal Science and Food Engineering, University of São Paulo, Pirassununga, SP, Brazil; ${ }^{2}$ Department of Pharmacology, Institute of Biosciences, São Paulo State University, Botucatu, SP, Brazil; ${ }^{3}$ Department of Biological Sciences, School of Science, Humanities and Languages - São Paulo State University, Assis, $\mathrm{SP}$, Brazil.

\section{*Corresponding author:}

Felipe Perecin

Department of Veterinary Medicine

Faculty of Animal Sciences and Food Engineering

University of São Paulo

Av. Duque de Caxias Norte, 225

Pirassununga, SP, Brazil, 13635900

Phone: +55 1935654162

Email: fperecin@usp.br

Short title: Oxidative stress disturbances in embryo

Conflict of interest: The authors declare that they have no conflict of interest.

Grant sponsor: This work was supported by the Sao Paulo Research Foundation (FAPESP grants 2014/21042-6 2014/21034-3, 2014/22887-0, 2013/08135-2 and 2012/50533-2). The 
funders had no role in study design, data collection and analysis, decision to publish, or preparation of the manuscript.

\begin{abstract}
During in vitro fertilization of mammalian embryos, the conceptuses are exposed to conditions distinct from the oviduct-uterine environment, including atmospheric oxygen that promotes cellular oxidative stress and consequently alters gene expression. High oxygen tension during embryo development has been associated with low pregnancy rates and increased embryonic apoptosis. Herein, we investigated the association of high $\left(20 \% \mathrm{O}_{2}\right)$ and low $\left(5 \% \mathrm{O}_{2}\right)$ oxygen tension during embryo culture with levels of reactive oxygen species (ROS), and changes in expression of oxidative stress-related and epigenetic-related transcripts and miRNAs in bovine blastocysts. Additionally we determined the global DNA methylation levels in the resulting embryos. Our results indicate that high oxygen tension leads to increased ROS levels in bovine blastocysts produced in vitro, which leads to increased expression of CAT, GLRX2, KEAP1, NFR2, PRDX1, PRDX3, SOD1, TXN, and TXNRD1, as well as the oxidative stress-related bta-miR-210. We also demonstrated that embryos undergoing oxidative stress have altered expression of the epigenetic-associated transcripts DNMT3A, H2AFZ, H3F3B, HDAC2, MORF4L2, REST, and PAF1, which correlates with increased global DNA methylation levels. Our results suggest that DNA hypermethylation is mediated by the deregulation of epigenetic-related enzymes due to oxidative stress.
\end{abstract}

Keywords: Epigenetic, microRNA, embryo development, ER stress. 


\section{Introduction}

In vitro production (IVP) of bovine embryos can be achieved in culture using two atmospheric conditions: high oxygen (20\%) or low oxygen (5\%) tension. High oxygen tension has been described as a condition that increases stressful factors, such as oxidative stress, in bovine and mouse embryos. ${ }^{1,2}$ Oxidative stress induced by high oxygen tension during in vitro embryo culture has been associated with cellular apoptosis ${ }^{3}$ and low pregnancy rates. $^{4,5}$

Oxidative stress in oxidant and antioxidant cell systems represents a disruption in the ratio of the production and degradation of reactive oxygen species (ROS), which are products of cellular aerobic metabolism. These metabolites are partially reduced molecules that are unstable and highly reactive. ${ }^{6}$ ROS interact with lipid, carbohydrate, and nucleic acid molecules, promoting cell damage such as lipid peroxidation, membrane and mitochondrial DNA changes, endoplasmic reticulum damage, and protein denaturation, and can also alter the meiotic cycle. ${ }^{7,8}$

Early embryo development occurs during migration of the embryo through the oviduct, under oxygen tension close to 5 to $7 \%$ under ideal physiological in vivo conditions. ${ }^{7,9}$ During this time, embryonic epigenetic reprogramming occurs, and environmental disturbances could lead to altered epigenetic patterns. ${ }^{10}$ Epigenetic reprogramming involves a wave of pronuclei demethylation, followed by a wave of de novo methylation. ${ }^{10,11}$ This process allows the modification of methylation levels inherited by parents (except for imprinted loci) and determines the methylation pattern of the embryos. ${ }^{12,13}$

Methylation is a well-known epigenetic modification characterized by the addition of a methyl radical at the 5-position of a cytosine molecule (5-methylcytosine). ${ }^{14}$ Typically, DNA methylation is established by DNA methyltransferases. The DNA methyltransferase 1 (DNMT1) maintains methylation patterns, preserving epigenetic information among subsequent cellular generations; ${ }^{15}$ and DNA methyltransferase 3 (DNMT3A and DNMT3B) establishes new patterns of methylation, determining the cell's individual epigenetic pattern. ${ }^{16,17}$ All DNMT isoforms can be detected during early embryo development, although DNMT3A is predominantly expressed. ${ }^{18}$

Variations in oxygen tension in in vitro culture conditions can alter DNA methylation levels in mammalian embryos, ${ }^{19}$ and can promote significant changes in transcript 
expression in bovine embryos. ${ }^{20,21}$ Oxidative stress also can induce changes in miRNA levels in cancer cells. ${ }^{22}$ In addition, the miR-210 has been descripted like a miRNA upregulated in general at low oxygen condition in cancer cell culture. ${ }^{23}$ Thus, altered oxygen tension can potentially induce major disturbances in miRNAs levels in embryonic cells leading to developmental problems. However, the effect of oxidative stress on miRNA expression in embryos is poorly explored.

In the present study, we tested whether bovine embryos exposed to high and low oxygen tension in vitro develop alterations in ROS and DNA methylation levels in the resulting blastocysts. Along with these functional modifications, we assessed the relative expression of genes related to oxidative stress responses, cellular stress responses, and epigenetic remodeling, as well as the expression of an miRNA associated with oxidative stress. We show that high oxygen tension in vitro promotes ROS accumulation in embryos and increased global DNA methylation. These functional modifications are followed by coordinated alterations in the expression patterns of stress-related and epigenetic-related genes and miRNAs.

\section{Materials and Methods}

A series of experiments were conducted to investigate the effects of oxygen tension during in vitro embryo culture. Reagents and media were purchased from Sigma Chemical Co. (St. Louis, MO, USA) unless otherwise indicated. The study was approved by the Ethics Committee on Animal Use of the Faculty of Animal Science and Food Engineering University of Sao Paulo, under protocol number 5763200215, and is in accordance with the rules issued by the National Council for Control of Animal Experimentation. For all experiments, incubator conditions for oocytes and embryos were maintained at $38.5^{\circ} \mathrm{C}$ and with maximum humidity. The gaseous atmosphere was $5 \% \mathrm{CO}_{2}$ and air for in vitro maturation, for IVF, and for in vitro culture of embryos grown under high oxygen tension. Atmosphere conditions of $5 \% \mathrm{CO}_{2}, 5 \% \mathrm{O}_{2}$, and $90 \% \mathrm{~N}_{2}$ were used during in vitro culture of embryos grown under low oxygen tension. 
In vitro embryo production

Bovine ovaries from a local slaughterhouse were collected and transported to the laboratory in thermal bottles filled with phosphate-buffered saline (PBS) until processing. Ovarian follicles between 3-6 mm were aspirated with 18-gauge needles and the oocytes selected under a stereomicroscope. Cumulus-oocyte-complexes (COCs) were washed in TCM199 culture medium supplemented with sodium pyruvate $(22 \mu \mathrm{g} / \mathrm{mL}$ ), gentamicin (50 $\mu \mathrm{g} / \mathrm{mL}$ ) and $10 \%$ extracellular vesicle-depleted bovine fetal serum (EVfreeFBS). Extracellular vesicle depletion was performed by ultracentrifugation at $120000 \times g$ for $16 \mathrm{~h}$. Non-atretic COCs with compact cumulus and homogeneous cytoplasm were selected and matured in vitro in TCM199 supplemented with $26 \mathrm{mM}$ sodium bicarbonate, $22 \mu \mathrm{g} / \mathrm{mL}$ sodium pyruvate, $50 \mu \mathrm{g} / \mathrm{mL}$ gentamicin, $10 \%$ EVfreeFBS, $0.5 \mu \mathrm{L} / \mathrm{mL}$ follicle stimulating hormone (FSH; Folltropin ${ }^{\circledR}$, Bioniche Animal Health, Belleville, ON, Canada), and $5 \mathrm{U} / \mathrm{mL}$ human chorionic gonadotropin (hCG, Vetecor ${ }^{\circledR} 5000$ U.I. Intervet, São Paulo, SP, Brazil). After COC selection and grading, a total of 20-25 structures (Grade I and II) were placed in $100 \mu \mathrm{L}$ droplets of maturation medium covered with mineral oil and incubated for 22 hours.

Following maturation, oocytes underwent IVF with frozen-thawed semen originated from a Nellore bull. Capacitated sperm were obtained after percoll gradient (45\% and $90 \%$ ). This study used semen from only one bull throughout the experiments. Fertilization medium was composed of Tyrode's-lactate (TL) stock, $50 \mu \mathrm{g} / \mathrm{mL}$ gentamicin, $22 \mu \mathrm{g} / \mathrm{mL}$ sodium pyruvate, $40 \mu \mathrm{L} / \mathrm{mL}$ PHE (2 mM D-penicillamine, $1 \mathrm{mM}$ hypotaurine, and $245 \mu \mathrm{M}$ epinephrine), $5.5 \mathrm{UI} / \mathrm{mL}$ heparin, and $6 \mathrm{mg} / \mathrm{mL}$ BSA (bovine serum albumin). After 18 hours, presumptive zygotes were partially denuded, and a monolayer of cumulus cells was kept to constitute the pseudo co-culture. ${ }^{24}$ Culture medium during development was the same for all groups: SOFaaci with $5 \mathrm{mg} / \mathrm{mL}$ BSA, $22 \mu \mathrm{g} / \mathrm{mL}$ sodium pyruvate, $50 \mu \mathrm{g} / \mathrm{mL}$ gentamicin, and $2.5 \%$ EVfreeFBS. Presumptive zygotes were divided in two groups for development under either high $\left(20 \% \mathrm{O}_{2}\right)$ or low $\left(5 \% \mathrm{O}_{2}\right)$ oxygen tension. On day 3 , cleavage rates were assessed, and on day 7, blastocyst rates were determined and samples were collected. Samples were either fixed for imaging analysis or stored at $-80^{\circ} \mathrm{C}$ until further use. This experiment comprised 23 independent embryo cultures distributed over a period of one year. 
ROS levels

Blastocysts (34 and 38 grown under high and low oxygen tension, respectively, from four different routines) were stained with $1 \mathrm{mmol} / \mathrm{L}$ of CellROX Green (Molecular Probes) for $30 \mathrm{~min}$ at $37^{\circ} \mathrm{C}$. Immediately after, embryos were fixed in $4 \%$ paraformaldehyde for $20 \mathrm{~min}$ and placed between a slide and coverslip. Fluorescence was captured by epifluorescence microscopy at $488 \mathrm{~nm}$, using $40 \mathrm{X}$ objective. Images were analyzed using the ImageJ software (NIH; http://rsb.info.nih.gov/ij/) to measure f. i.

RNA isolation

Total RNA, including small non-coding RNAs, was extracted from pools of 10 blastocysts by using QIAzol Lysis reagent followed by purification of the aqueous phase in miRNeasy ${ }^{\circledR}$ micro kit (Qiagen, Venlo, Limburg, Netherlands) following the manufacturer's instructions. RNA pellets were dissolved in $14 \mu \mathrm{L}$ RNase-free water. RNA concentrations were measured using NanoDrop 2000 (Applied Biosystems, Foster City, CA, USA).

Gene expression

Gene expression analysis was performed using Biomark HD (Fluidigm, South San Francisco, CA, USA), using eight different routines of pools of 10 blastocysts. The relative expression of 31 genes was determined (Table 1) in eight biological replicates. A total of 100 ng total RNA was reverse transcribed with High-Capacity cDNA Reverse Transcription Kit (Applied Biosystems Foster, City, CA, USA), according to manufactures's instructions. Sequence-specific preamplification used approximately $5 \mathrm{ng}(1.25 \mu \mathrm{L}) \mathrm{cDNA}, 1.25 \mu \mathrm{L}$ assay mix (Taqman ${ }^{\circledR}$ Assay was pooled to a final concentration of $0.2 \mathrm{X}$ for each of the 96 assays), and $2.5 \mu \mathrm{L}$ TaqMan PreAmp Master Mix (\#4391128). The reactions were incubated at $95^{\circ} \mathrm{C}$ for $10 \mathrm{~min}$ and $14 \mathrm{cycles}$ of $95^{\circ} \mathrm{C}$ for $15 \mathrm{~s}$ followed by $60^{\circ} \mathrm{C}$ for $4 \mathrm{~min}$. These preamplified products were diluted 6-fold prior to RT-qPCR analysis. 
Table 1. Gene symbols, gene names and assay ID used for relative expression of transcripts related to oxidative stress, cellular stress and epigenetic remodeling.

\begin{tabular}{|c|c|c|}
\hline Gene symbol & Assay ID* & Gene name \\
\hline ATF4 & Bt03221057_m1 & Activating transcription factor 4 \\
\hline CAT & Bt03228713_m1 & Catalase \\
\hline DDIT3 & Bt03251320_g1 & DNA-damage-inducible transcript 3 \\
\hline DNMT1 & Bt03224737_m1 & DNA (Cytosine-5-)-Methyltransferase 1 \\
\hline DNMT3A & Bt01027164_m1 & DNA (Cytosine-5-)-Methyltransferase 3A \\
\hline DNMT3B & Bt03259810_m1 & DNA (Cytosine-5-)-Methyltransferase 3B \\
\hline FOXO3 & Bt03649334_s1 & Forkhead box $\mathrm{O3}$ \\
\hline GADD45A & Bt03225650_m1 & Growth arrest and DNA-damage-inducible, alpha \\
\hline GLRX2 & Bt03229700_m1 & Glutaredoxin 2 \\
\hline GPX1 & Bt03259217_g1 & Glutathione Peroxidase 1 \\
\hline GPX4 & Bt03259611_m1 & Glutathione peroxidase 4 \\
\hline GRP78 & Bt03244880_m1 & Glucose-regulated protein, $78 \mathrm{kDa}$ \\
\hline$H 2 A F Z$ & Bt03216346_g1 & H2A histone family, member Z \\
\hline H3F3A & Bt03278804_g1 & H3 histone, family $3 \mathrm{~A}$ \\
\hline HDAC2 & Bt03244871_m1 & Histone deacetylase 2 \\
\hline HIF1A & Bt03259341_m1 & Hypoxia inducible factor 1 (transcription factor) \\
\hline HSP9OAA1 & Bt03218068_g1 & Heat Shock Protein 90kDa Alpha \\
\hline HSPA1A & Bt03292670_g1 & Heat shock $70 \mathrm{kDa}$ protein $1 \mathrm{~A}$ \\
\hline IMPDH1 & Bt00995384_m1 & IMP (inosine 5'-monophosphate) dehydrogenase 1 \\
\hline KEAP1 & Bt03817661_m1 & Kelch-like ECH-associated protein 1 \\
\hline MORF4L2 & Bt03270996_m1 & Mortality factor 4 like 2 \\
\hline NRF2 & Bt03251880_m1 & Nuclear factor (erythroid-derived 2)-like 2 \\
\hline PAF1 & Bt03239371_g1 & RNA Polymerase II Associated Factor \\
\hline PRDX1 & Bt03223684_m1 & Peroxiredoxin-1 \\
\hline PRDX3 & Bt03214402_m1 & Peroxiredoxin 3 \\
\hline REST & Bt03278318_s1 & RE1-silencing transcription factor \\
\hline SOD1 & Bt03215423_g1 & Superoxide dismutase 1 , soluble \\
\hline SOD2 & Bt03244551_m1 & Superoxide dismutase 2 , mitochondrial \\
\hline$T X N$ & Bt03222879_m1 & Thioredoxin \\
\hline TXNRD1 & Bt03215471_m1 & Thioredoxin reductase 1 \\
\hline XBP1 & Bt03227621_g1 & X-Box Binding Protein 1 \\
\hline ACTB $^{* *}$ & PA5-16914 & Actin beta \\
\hline GAPDH** & Bt03210912_g1 & Glyceraldehyde-3-phosphate dehydrogenase \\
\hline PPIA** & Bt03224617_g1 & Peptidylprolyl Isomerase A \\
\hline
\end{tabular}

* Thermo Fisher Scientific; ${ }^{* *}$ housekeepings

For mRNA expression analysis, the prepared sample solution consisted of $2.25 \mu \mathrm{L}$ CDNA (preamplified products), $2.5 \mu \mathrm{L}$ TaqMan Universal PCR Master Mix (2X, Applied Biosystems), and $0.25 \mu \mathrm{L} 20 \mathrm{X}$ GE Sample Loading Reagent (Fluidigm); and the assay solution consisted of $2.5 \mu \mathrm{L}$ of 20X TaqMan Gene Expression Assay (Applied Biosystems) and $2.5 \mu \mathrm{L}$ of 2X Assay Loading Reagent (Fluidigm). The 96.96 Dynamic Array ${ }^{\mathrm{TM}}$ Integrated Fluidic Circuits 
(Fluidigm) chip was used for data collection. After priming, the chip was loaded with $5 \mu \mathrm{L}$ of each assay solution and $5 \mu \mathrm{L}$ of each sample solution. The qPCR thermal cycling was performed using Biomark HD System and TaqMan GE 96x96 Standard protocol, as follows: one stage of Thermal Mix $\left(50^{\circ} \mathrm{C}\right.$ for $2 \mathrm{~min}, 70^{\circ} \mathrm{C}$ for $20 \mathrm{~min}$, and $25^{\circ} \mathrm{C}$ for $\left.10 \mathrm{~min}\right)$; a Hot Start stage $\left(50^{\circ} \mathrm{C}\right.$ for $2 \mathrm{~min}$ and $95^{\circ} \mathrm{C}$ for $\left.10 \mathrm{~min}\right)$; and 40 cycles of denaturation $\left(95^{\circ} \mathrm{C}\right.$ for $\left.15 \mathrm{~s}\right)$, primer annealing, and extension $\left(60^{\circ} \mathrm{C}\right.$ for $\left.60 \mathrm{~s}\right)$. To identify the differences in transcript levels between blastocysts cultured under high and low oxygen tension, raw $\mathrm{Ct}$ values were normalized to the geometrical mean of three internal controls (ACTB, GAPDH, and PPIA;

Table 2). Normalized Cts were transformed to $2^{-\Delta C t}$ to obtain the relative expression value. Expression levels were determined in eight biological replicates.

\section{MicroRNA expression}

The level of bta-miR-210 was investigated by RT-qPCR. Total RNA from three different routines of pools of 10 blastocysts was used for cDNA reverse transcription preparation using Mix from miScriptII RT Kit (Qiagen, Venlo, Limburg, Netherlands) following the manufacturer's instructions. Reactions of $10 \mu \mathrm{L}$ were carried out with approximately 100 ng total RNA, $2 \mu \mathrm{L} 5 \mathrm{x}$ Hiflex buffer, $2 \mu \mathrm{L}$ 10x Nucleic Mix, $1 \mu \mathrm{L}$ reverse transcriptase, and water at $37^{\circ} \mathrm{C}$ for $60 \mathrm{~min}$, followed by $5 \mathrm{~min}$ at $95^{\circ} \mathrm{C}$.

Real time qPCR reactions were performed with 1,2 ng of the resulting CDNA using SYBR Green PCR Master Mix (\#1020722) and sequence-specific forward (Table 3) and reserve universal primers (Qiagen, Venlo, Limburg, Netherlands). The PCR conditions were as follows: $95^{\circ} \mathrm{C}$ for $15 \mathrm{~min}$; and 45 cycles of $94^{\circ} \mathrm{C}$ for $15 \mathrm{~s}, 55^{\circ} \mathrm{C}$ for $30 \mathrm{~s}$, and $70^{\circ} \mathrm{C}$ for $30 \mathrm{~s}$. PCR was carried out using the QuantStudio6 Flex system (Applied Biosystems, Foster City, CA, USA). Melt curve analyses confirmed the amplification of specific cDNA products. Samples with three or more melt curves were discarded. To identify differences in miRNA levels in blastocysts cultured under high or low oxygen tension, raw $\mathrm{Ct}$ values were normalized by the geometrical mean of three internal controls (RNU43 snoRNA, Hm/Ms/Rt U1 snRNA, and btamiR-99b; Table 2). Normalized Cts were transformed to $2^{-\Delta C t}$ to obtain the relative expression value. Expression levels were determined in three biological replicates. 
Table 2. Forward sequence-specific primers used for determining the relative expression of bovine miRNAs. Housekeeping small non-coding RNAs used for normalization are indicated $(*)$.

\begin{tabular}{lc}
\hline \multicolumn{1}{c}{ miRnA } & Sequence \\
\hline bta-miR-210 & 5' ACTGTGCGTGTGACAGCGGCTGA 3' \\
RNU43 snoRNA* & 5' CTTATTGACGGGCGGACAGAAAC 3' \\
Hm/Ms/Rt U1 snRNA* & 5' CGACTGCATAATTTGTGGTAGTGG 3' \\
bta-miR-99b* & 5' CACCCGTAGAACCGACCTTGCG 3' \\
\hline
\end{tabular}

Global DNA methylation levels

Global DNA methylation was determined by immunofluorescence to detect $5 \mathrm{mC}$ in blastocysts developed under high or low oxygen tension. Twelve blastocysts grown under high oxygen tension and nine grown under low oxygen tension were fixed in $4 \%$ paraformaldehyde for $20 \mathrm{~min}$ and stored in PBS at $4^{\circ} \mathrm{C}$ for future analysis. Embryos were permeabilized with $0.5 \%$ saponin in PBS incubated for $10 \mathrm{~min}$ at room temperature. DNA denaturation process was achieved by exposing samples to $4 \mathrm{~N} \mathrm{HCl}$ for $12 \mathrm{~min}$, and neutralization by $100 \mathrm{mM}$ Tris $\mathrm{HCl}$ solution for $20 \mathrm{~min}$. Embryos were blocked in PBS solution with $1 \% \mathrm{BSA}$ and $0.3 \mathrm{M}$ glycine for 1 hour. After blocking, samples were incubated with primary antibody for 5-methylcytidine (1:500, \#SC56615, Santa Cruz Biotechnology, Santa Cruz, CA, USA) overnight at $4^{\circ} \mathrm{C}$. The following morning, samples were washed three times in PBS and incubated with the secondary antibody, anti-mouse IgG (1:500, \#A11029, Applied Biosystems, Foster City, CA, USA) 1 hour at room temperature. Fluorescence was evaluated by confocal microscopy, Leica SP5 (Leica Microsystems, Wetzlar, WZ, Germany), using a 40X oil immersion objective. Samples were excited with HeNe 543 laser, using the emission gate between 590 to $630 \mathrm{~nm}$. A total of five Z-stack images per embryo were acquired and five blastomeres per image (25 blastomers/embryo) were used for analysis with ImageJ $(\mathrm{NIH}$; http://rsb.info.nih.gov/ij/) to measure f. i.

\section{Statistical data analysis}

Comparisons between high and low oxygen tension were made by two-tailed Student's T-test following two-sample and homoscedastic parameters. Levene's test was used to test homoscedasticity. Data were log-transformed for ROS and global DNA 
methylation analysis. All analyses were performed using SAS 9.3 Software (SAS Institute), and statistical significance was assumed if $p \leq 0.05$ unless otherwise indicated.

\section{Results}

In vitro development of bovine embryos under high and low oxygen tension

Embryos grown in vitro under high and low oxygen tension resulted in similar cleavage and blastocyst rates on day 3 and day 7 of embryonic development, respectively. These data were acquired over 23 routines of in vitro embryo production. Cleavage rates were $83.23 \%$ and $82.92 \%$ for high and low oxygen tension, respectively, and the blastocyst rates were $27.24 \%$ and $23.96 \%$ for high and low oxygen tension, respectively (Table 3 ).

Table 3. Cleavage and blastocysts rates during in vitro production of bovine embryos under high (20\%) and low (5\%) oxygen tensions.

\begin{tabular}{lccccc}
\hline No & Nc & $\begin{array}{c}\text { Cleavage Rate } \\
\text { (mean } \pm \text { SD) }\end{array}$ & Nb & $\begin{array}{c}\text { Blastocyst Rate } \\
\text { (mean } \pm \text { SD) }\end{array}$ \\
\hline High $\mathbf{O}_{2}$ & 1,908 & 1,591 & $83.23 \% \pm 4.23$ & 485 & $27.24 \% \pm 10.99$ \\
Low O & 1,872 & 1,557 & $82.92 \% \pm 6.31$ & 422 & $23.96 \% \pm 9.36$ \\
\hline TOTAL & 3,780 & 3,148 & - & 907 & - \\
\hline $\begin{array}{l}\text { No= Number of oocytes; } \\
\text { deviation }\end{array}$
\end{tabular}

ROS levels

To evaluate ROS levels, we collected blastocysts exposed to high and low oxygen tension over the course of seven days in culture. We observed significantly higher levels of ROS in embryos cultured under high tension $(1.057 \pm 0.136$ fluorescence intensity [f.i.]) compared to those cultured at low oxygen tension (0.945 $\pm 0.181 \mathrm{f}$.i.; Figure 1$)$. 

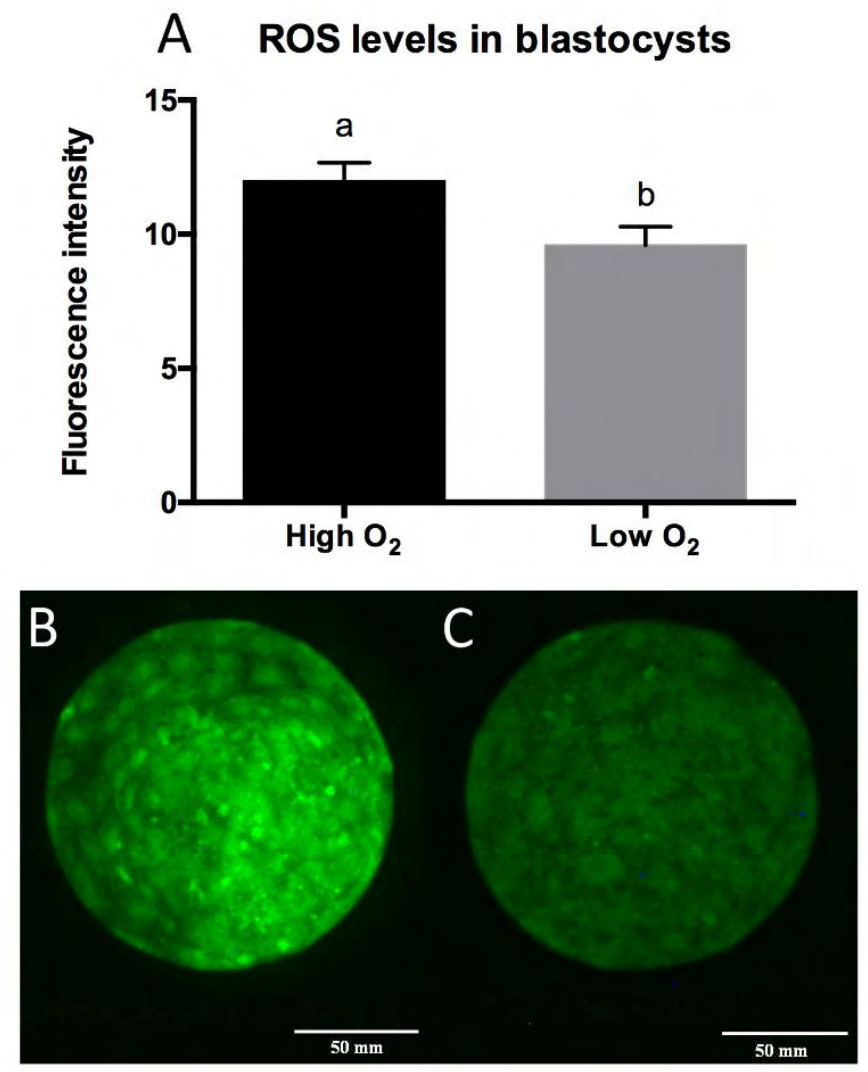

Figure 1. Reactive oxygen species (ROS) levels. (A) ROS levels in bovine blastocysts produced in vitro under high $(20 \%)$ and low $(5 \%)$ oxygen tensions. Bars represent the group average and error bars represent the standard error of the mean. Bars with different letters above them are statistically different $(p \leq 0.05)$. Representative photomicrographs of a blastocyst cultured under high (B) and low (C) oxygen tensions stained with CellROX Green (Molecular Probes) for intracellular ROS analysis. Embryos of photomicrographs was analyze by epifluorescence microscopy at $488 \mathrm{~nm}$ and using $40 \mathrm{X}$ objective.

mRNA levels in blastocysts exposed to high and low oxygen tension

We investigated the effects of oxygen tension on blastocyst transcript levels of twelve genes associated with oxidative stress responses (Figure 2A) and ten genes associated with cellular stress responses (Figure $2 \mathrm{~B}$ ). The expression of ten (CAT, GLRX2, HSP9OAA1, KEAP1, NRF2, PRDX1, PRDX3, SOD1, TXN, and TXNRD1) out of the 22 genes analyzed was higher $(p \leq 0.05)$ in embryos cultured at high oxygen tension compared to low oxygen tension (Figure 2A and 2B; Supplementary Table S1). 
Additionally, we analyzed the effect of oxidative stress on the expression levels of nine mRNAs related to epigenetic remodeling (Figure 3). We found that seven genes (DNMT3A, H2AFZ, H3F3B, HDAC2, MORF4L2, PAF1, and REST) were upregulated in embryos cultured at high oxygen tension compared to those grown at low oxygen tension (Figure 3; Supplementary Table S1).
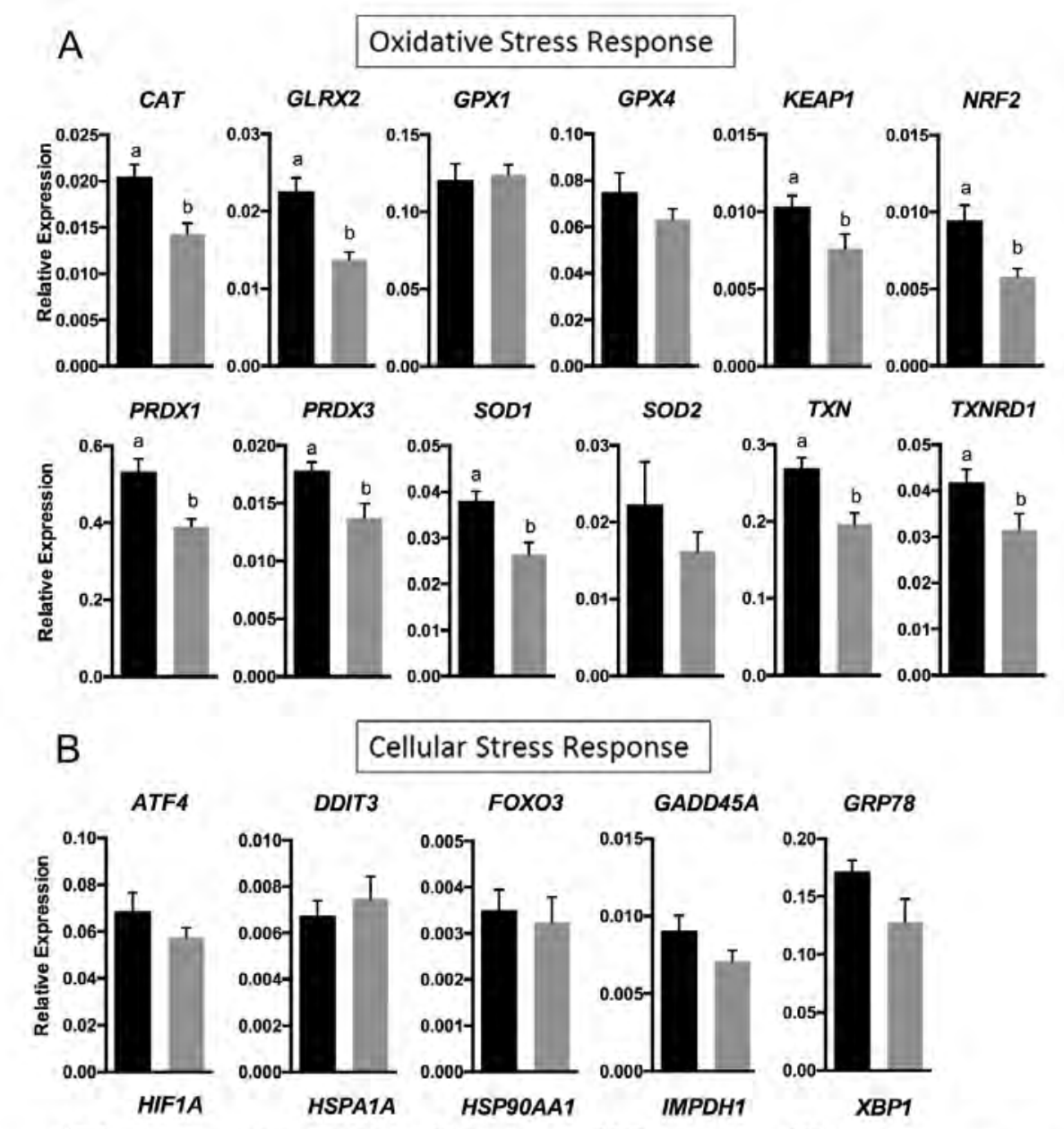

Cellular Stress Response
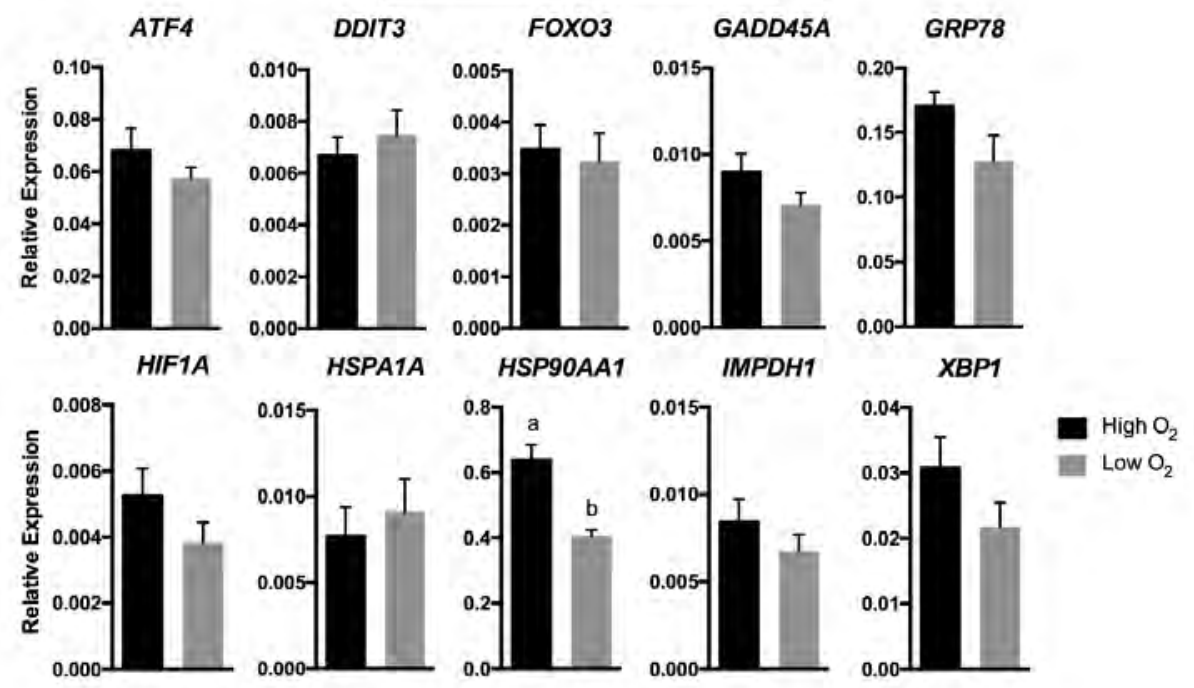

Figure 2. Relative levels of transcripts associated with the oxidative stress response $(A)$ and cellular stress response (B). Relative expression of 22 genes in bovine blastocysts produced in vitro under high (20\%) and low (5\%) oxygen tension. Bars represent the group average for eight biological replicates. Error bars represent the standard error of the mean. Bars with different letters above them are statistically different $(p \leq 0.05)$. 


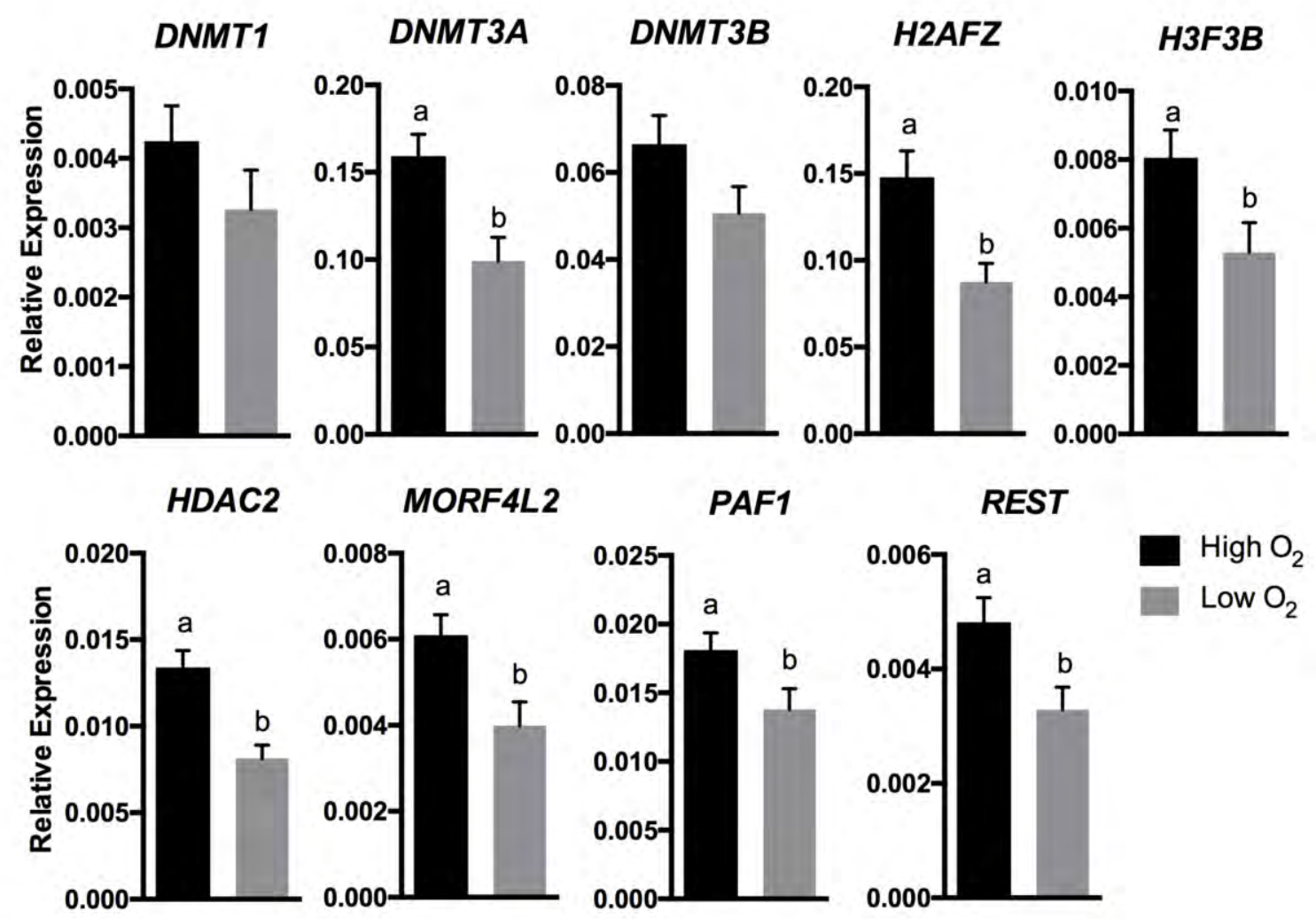

Figure 3. Relative levels of transcripts associated with epigenetic remodeling. Relative expression of nine genes in bovine blastocysts produced in vitro under high (20\%) and low (5\%) oxygen tension. Bars represent the group average for eight biological replicates. Error bars represent the standard error of the mean. Bars with different letters above them are statistically different $(p \leq 0.05)$.

miRNA-210 level in blastocysts cultured in high and low oxygen tension

The effect of high and low oxygen tension on miRNA-210 expression levels was examined in bovine blastocysts. The bta-miR-210 was downregulated $(p \leq 0.05)$ in embryos cultured at high oxygen tension $(0.003161 \pm 0.000335)$ compared to low oxygen tension (0.005046 $\pm 0.000839 ;$ Figure 4). 


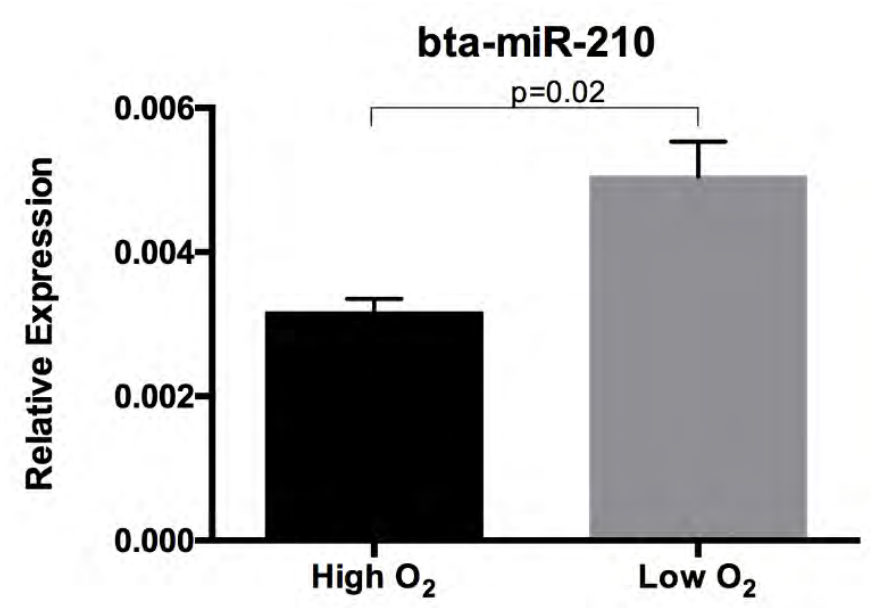

Figure 4. Relative levels of microRNA expression. Relative expression bta-miR-210 in bovine blastocysts produced in vitro under high (20\%) and low (5\%) oxygen tension. Bars represent the group average for three biological replicates. Error bars represent the standard error of the mean. Brackets indicate differences between groups considering the informed $p$-value.

Global DNA methylation analysis

The global levels of DNA methylation were determined in bovine blastocysts using an antibody against 5-methylcytosine $(5 \mathrm{mC})$. The global DNA methylation levels were different between blastocysts cultured in high and low oxygen tension. Embryos cultured at high oxygen tension demonstrated higher DNA methylation levels (22.86 \pm 9.69 f.i.) compared to low oxygen tension (19.49 \pm 9.08 f.i.; Figure 5). 


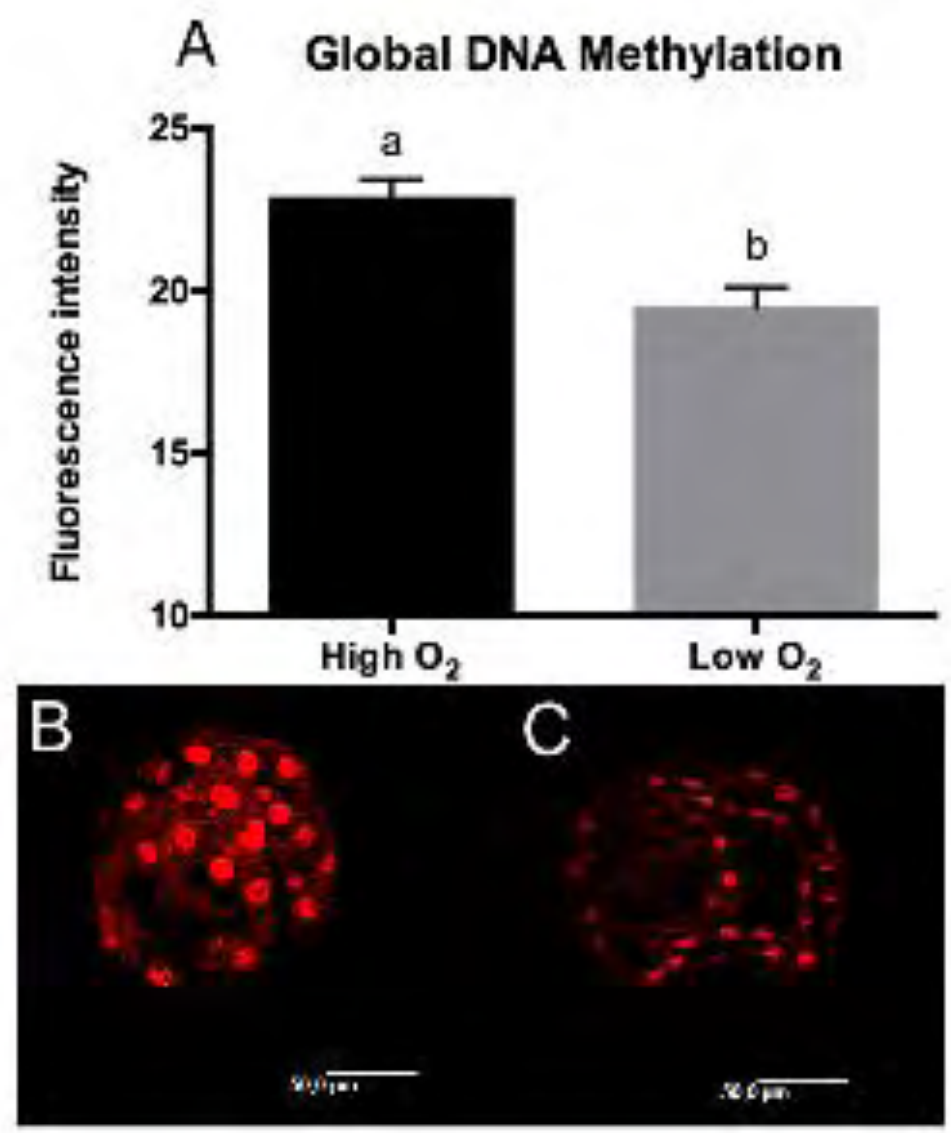

Figure 5. Global DNA methylation levels. (A) Levels of global DNA methylation determined by confocal microscopy and image analysis in bovine blastocysts produced in vitro under high $(20 \%)$ and low (5\%) oxygen tension. Bars represent the group average and error bars represent the standard error of the mean. Bars with different letters above them are statistically different $(p \leq 0.05)$. Representative photomicrographs of bovine embryos cultured in high (B) and low (C) oxygen tension immunostained for 5-methylcytosine antibody (\#SC56615). Embryos of photomicrographs was analyze by confocal microscopy using the emission gate between 590 to $630 \mathrm{~nm}$ and $40 \mathrm{X}$ objective with oil.

\section{Discussion}

Present study aimed to identified the changes induced by oxidative stress condition during in vitro early embryo development. For this purpose the embryos were produced in vitro and developed in different atmospheres. Bovine embryos were cultured at high (20\%) or low (5\%) oxygen tension. Cleavage and blastocyst rates following exposure to these two atmospheres were similar between groups (Table 1). This is consistent with previous studies 
that found similar cleavage and blastocyst rates after in vitro culture of embryos grown under different oxygen tensions. ${ }^{21,25}$ In addition, reduced pregnancy rates of embryos cultured in high oxygen tension have been reported, ${ }^{4,5}$ suggesting that high oxygen tension has detrimental effects that arise later in development. Our next goal was to determine if the high oxygen tension was able to generate an oxidative stress condition. For that we evaluated the formation of ROS, an indicative of oxidative stress. ${ }^{3}$ We found that high oxygen tension promotes an increase in ROS levels in the blastocysts (Figure 1), likely leading to increased cellular damage. Excessive ROS levels are related to poor embryo quality and delayed embryo development due to oxidative stress damage. ${ }^{2}$ Our results demonstrate that ROS level variations due to the gaseous atmosphere do not lead to noticeable differences in embryo developmental rates. However, as has been reported, ${ }^{3}$ embryos produced under higher oxygen tension are more prone to further detrimental consequences on development.

To determine whether molecular consequences of oxidative stress could be detected as early as the blastocyst stage, we measured the expression of genes involved in the oxidative stress response. Interestingly, nine (CAT, GLRX2, KEAP1, NRF2, PDRX1, PRDX3, SOD1, TXN, and TXNRD1) out of the twelve genes (also including GPX1, GPX4, and SOD2) had higher expression under high oxygen tension compared to low oxygen tension (Figure 2A). These results clearly indicate that ROS scavenging systems or other antioxidant responses are activated in blastocysts with increased ROS levels. For example, CAT converts $\mathrm{H}_{2} \mathrm{O}_{2}$ into water, ${ }^{1}$ SOD1 catalyzes a dissolution reaction to remove ROS, $^{26}$ PRDX1 and PRDX3 are thioredoxin-dependent peroxide reductases that reduce the intracellular concentrations of $\mathrm{H}_{2} \mathrm{O}_{2},{ }^{27}$ TXN is a disulfide reductase that reduces ROS levels, ${ }^{28,29}$ and KEAP1 and NRF2 are involved in the transcriptional activation of genes that improve the expression of antioxidant enzymes. ${ }^{30}$ GLRX2 is a member of the glutaredoxin family proteins that maintain cellular thiol homeostasis. ${ }^{31}$ Thiol molecules are responsible for glutathione (GSH) synthesis through the $\gamma$-glutamyl-cysteine cycle. GSH is a non-enzymatic embryo antioxidant that removes excess ROS by reducing peroxides and hydroperoxides in inactive products. ${ }^{32,33}$ On the other hand, overexpression of GLRX2 can effectively protect TXN from oxidation, preserving its function in the mitochondrial oxidative stress response. ${ }^{34}$ Therefore, although there were no effects on the rate of blastocyst development, blastocysts grown under high and low oxygen 
tension have molecular differences characterized by the upregulation of antioxidant systems.

The high levels of oxygen under which the embryos developed activate oxidative stress responses in the resulting blastocysts, as elucidated by upregulation of antioxidant pathways. To test if other cellular stress responses are also activated in these embryos, we assessed the expression of genes associated with the endoplasmic reticulum (ER) stress response (ATF4, DDIT3, GRP78, HSPA1A, and XBP1), with DNA damage repair and DNA/RNA metabolism (GADD45A, HSP9OAA1, and IMPDH1), apoptosis (FOXO3), and hypoxia (HIF1A). Only HSP9OAA1 mRNA levels differed between embryos produced under high and low oxygen tension (Figure 2B). HSP90AA1 belongs to the HSP90 family of molecular chaperones. The HSP9O proteins modulate DNA repair machinery in response to DNA damage. ${ }^{35-37}$ Thus, the most likely reason for the increase in HSP9OAA1 expression in blastocysts derived from high oxygen culture conditions relies on the HSP90-induced activation of DNA repair. The increase in ROS levels in these blastocysts, a well-known trigger of DNA damage, supports this assumption. Hence, there is no evidence that the cellular insults generated by high oxygen tension result in ER stress response activation, FOXO-induced apoptosis, or hypoxiainduced gene transcription activation. On the other hand, the results support that HSP9Oinduced DNA damage repair may occur.

Reproductive biotechnologies, such as in vitro fertilization (IVF), generate changes in DNA methylation dynamics during development. ${ }^{38}$ In view of this, we investigated the expression levels of genes involved in epigenetic remodeling (DNMT1, DNMT3A, DNMT3B, H2AFZ, H3F3B, HDAC2, MORF4L2, PAF1, and REST) (Figure 3). We found that the transcripts of two histone genes, $H 2 A F Z$ and $H 3 F 3 B$, are upregulated in high oxygen tension conditions compared to low. In addition, the mRNA of MORF4L2, a gene that participates in the histone acetyltransferase complex, was upregulated under high oxygen tension. Similarly, HDAC2 (a histone deacetylating agent), REST (mediates deacetylation and demethylation of some histone sites), and PAF1 were also found to be upregulated under high oxygen tension. PAF1 is involved in histone methylation, and PAF1 expression is important to allow proper cellular differentiation as demonstrated in mice. ${ }^{39}$ DNMT3A transcripts were also increased in embryos grown under high oxygen tension compared to low tension. DNMT3A performs de novo methylation preferentially in the methylation islands (CpGs), an essential process involved in establishment of embryonic methylation levels. ${ }^{40}$ Therefore, these results 
indicate that intense epigenetic remodeling occurs in response to high oxygen tension during early embryo development in cattle.

In view of the reports of changes in miRNA expression induced by oxidative stress during culture of different cell types, ${ }^{22,23}$ we investigated the expression of miR-210 to different atmosphere condition. Our results demonstrate that miR-210 is downregulated in embryos cultured under high oxygen tension. miR-210 serves as a marker of hypoxia. ${ }^{23}$ In addition, miR-210 plays a pivotal role in regulating mitochondrial activity, and consequently ROS production. ${ }^{41}$ Specifically, miR-210 targets intermediate genes of oxidative metabolism in mitochondria, reducing oxidative phosphorylation and ROS formation. ${ }^{41}$ Accordingly, embryos produced under low oxygen tension have lower ROS levels and higher bta-miR-210 expression. The expression of miR-210 is controlled by transcription factors and by methylation in the promoter $\mathrm{CpG}$ island. In particular, miR-210 transcription is regulated by HIF1A, ${ }^{42}$ the expression of which was not affected by oxygen tension in our study. Additionally, miR-210 expression is directly controlled by DNA methylation in its promoter region. $^{43}$ Therefore, the increase in DNA methyltransferase $3 \mathrm{~A}$ and in global DNA methylation, as demonstrated in our study for embryos produced under high oxygen tension, may lead to methylation of the miR-210 gene and reduced expression. Thus, our results are consistent with increased ROS production under high oxygen tension, reduced bta-miR-210 expression, and a probable increase in methylation of bta-miR-210 methylation islands.

In order to identify DNA methylation level modifications in bovine blastocysts grown under high and low oxygen tension, we determined the global levels of $5 \mathrm{mC}$ by immunofluorescence and confocal imaging. The global DNA methylation levels increased in embryos cultured in high oxygen tension compared to low oxygen tension. The increased DNA methylation levels are likely an indirect effect of the oxidative stress induced in the embryo. Cellular oxidative stress, ROS accumulation, and methylation level changes have already been reported by others. ${ }^{19,44}$ Overexpression of DNMT1 under oxidative stress is thought to be responsible for increased methylation by preventing proper demethylation during early embryonic reprogramming. ${ }^{22,45}$ We did not observe a difference in DNMT1 expression in blastocysts cultured in high and low oxygen tension. However, we did demonstrate that oxidative stress deregulates the expression of epigenetic enzymes involved in de novo methylation (DNMT3A) and histone modification (HDAC2, MORF4L2, 
PAF1, and REST), which could ultimately explain the observed increase in global DNA methylation.

In conclusion, we found that high oxygen tension during in vitro bovine embryo production increases ROS levels compared to low oxygen tension in the resulting blastocysts. The high ROS levels indicate the presence of oxidative stress, which is accompanied by increased expression of genes related to antioxidant responses, decreased expression of btamiR-210, and the recruitment of DNA-repair machinery. Several transcripts of epigenetic writers and erasers are upregulated in blastocysts produced under oxidative stress conditions, suggesting a global epigenetic disturbance. This is supported by an increase in global DNA methylation levels in the corresponding embryos. Therefore, while developmental rates of embryos cultured under high and low oxygen tensions are similar, molecular changes arise as early as the preimplantation stage. The intricate relationship between the molecular mechanisms involved in embryo competence acquisition and reprogramming under oxidative stress, as well as the long-term repercussions, are still not completely understood.

\section{Acknowledgements}

The authors are thankful to CRV Lagoa that kindly donated the semen for bovine embryo in vitro production.

\section{Funding}

This work was supported by the Sao Paulo Research Foundation (FAPESP - grants 2014/21042-6 2014/21034-3, 2014/22887-0, 2013/08135-2 and 2012/50533-2). The funders had no role in study design, data collection and analysis, decision to publish, or preparation of the manuscript.

\section{Declaration of Conflicting Interests}

The authors declare that they have no conflict of interest. 


\section{References}

1. Harvey MB, Arcellana-Panlilio MY, Zhang X, Schultz GA, Watson AJ. Expression of genes encoding antioxidant enzymes in preimplantation mouse and cow embryos and primary bovine oviduct cultures employed for embryo coculture. Biol Reprod. 1995;53:532-540.

2. Amin A, Gad A, Salilew-Wondim D, et al. Bovine embryo survival under oxidative-stress conditions is associated with activity of the NRF2-mediated oxidative-stress-response pathway. Mol Reprod Dev. 2014;81:497-513.

3. Yoon S, Choi S, Sim J, et al. Developmental competence of bovine early embryos depends on the coupled. Biol Reprod. 2014;90:1-10.

4. Dumoulin JCM, Meijers CJJ, Bras M, Coonen E, Geraedts PM, Evers JLH. Effect of oxygen concentration on human in-vitro fertilization and embryo culture. Hum Reprod. 1999;14:465-469.

5. Bontekoe S, Mantikou E, van Wely M, Seshadri S, Repping S, Mastenbroek S. Low oxygen concentrations for embryo culture in assisted reproductive technologies. Cochrane Database Syst Rev. 2012;7:1-41.

6. Agarwal A, Saleh RA, Bedaiwy MA. Role of reactive oxygen species in the pathophysiology of human reproduction. Fertil Steril. 2003;79:829-843.

7. Harvey AJ. The role of oxygen in ruminant preimplantation embryo development and metabolism. Anim Reprod Sci. 2007;98:113-128.

8. Rocha-Frigoni NAS, Leão BCS, Nogueira E, Accorsi MF, Mingoti GZ. Reduced levels of intracellular reactive oxygen species and apoptotic status are not correlated with increases in cryotolerance of bovine embryos produced in vitro in the presence of antioxidants. Reprod Fertil Dev. 2014;26:797805.

9. Fischer B, Bavister BD. Oxygen tension in the oviduct and uterus of rhesus monkeys, hamsters and rabbits. J Reprod Fertil. 1993;99:673-679.

10. Mann MRW, Bartolomei MS. Epigenetic reprogramming in the mammalian embryo: struggle of the clones. Genome Biol. 2002;3:1-4.

11. Reik W, Dean W, Walter J. Epigenetic Reprogramming in Mammalian Development. Science. 2001;293:1089-1093.

12. Nakamura $T$, Liu $Y$, Nakashima $H$, et al. PGC7 binds histone H3K9me2 to protect against conversion of $5 \mathrm{mC}$ to $5 \mathrm{hmC}$ in early embryos. Nature. 2012;486:415-419.

13. Graf A, Krebs S, Zakhartchenko V, Schwalb B, Blum H, Wolf E. Fine mapping of genome activation in bovine embryos by RNA sequencing. PNAS. 2014;111:4139-4144.

14. Bird A. DNA methylation patterns and epigenetic memory. Genes Dev. 2002;16:6-21. 
15. Hirasawa $\mathrm{R}$, Chiba $\mathrm{H}$, Kaneda $\mathrm{M}$, et al. Maternal and zygotic Dnmt1 are necessary and sufficient for the maintenance of DNA methylation imprints during preimplantation development. Genes Dev. 2008;22:1607-1616.

16. Okano M, Bell DW, Haber DA, Li E. DNA methyltransferases Dnmt3a and Dnmt3b are essential for de novo methylation and mammalian development. Cell. 1999;99:247-257.

17. Uysal F, Akkoyunlu G, Ozturk S. Dynamic expression of DNA methyltransferases (DNMTs) in oocytes and early embryos. Biochimie. 2015;116:103-113.

18. Watanabe D, Sato T, Amano T, et al. Stage-and cell-specific expression of Dnmt3a and Dnmt3b during embryogenesis. Mech Dev. 2002;118:187-190.

19. Li W, Goossens K, Poucke MV, et al. High oxygen tension increases global methylation in bovine 4cell embryos and blastocysts but does not affect general retrotransposon expression. Reprod Fertil Dev. 2014;28:948-959.

20. Rizos D, Lonergan P, Boland MP, et al. Analysis of differential messenger RNA expression between bovine blastocysts produced in different culture systems: implications for blastocyst quality. Biol Reprod. 2002;66:589-595.

21. Harvey AJ, Kind KL, Pantaleon M, Armstrong DT, Thompson JG. Oxygen-regulated gene expression in bovine blastocysts. Biol Reprod. 2004;71:1108-1119.

22. He J, $X u Q$, Jing $Y$, et al. Reactive oxygen species regulate ERBB2 and ERBB3 expression via miR-199a/125b and DNA methylation. EMBO Reports. 2012;13:1116-1122.

23. Kulshreshtha R, Ferracin M, Wojcik SE, et al. A microRNA signature of hypoxia. Mol Cell Biol. 2007;27:1859-1867.

24. Wydooghe E, Vandaele L, Heras $S$, et al. Autocrine embryotropins revisited: how do embryos communicate with each other in vitro when cultured in groups? Biol Rev Camb Philos Soc. 2015;92:1-16.

25. Gaspar RC, Arnold DR, Corrêa CAP, et al. Oxygen tension affects histone remodeling of in vitroproduced embryos in a bovine model. Theriogenology. 2015;83:1408-1415.

26. Halliwell B, Gutteridge JMC. Reactive species can pose special problems needing special solutions: some examples. In: Halliwell B, Gutteridge JMC. Free Radicals in Biology and Medicine. Oxford: Oxford University Press; 2015:354-410.

27. Leyens G, Knoops B, Donnay I. Expression of peroxiredoxins in bovine oocytes and embryos produced in vitro. Mol Reprod Dev. 2004;69:243-251.

28. Matsui M, Oshima M, Oshima H, et al. Early embryonic lethality caused by targeted disruption of the mouse thioredoxin gene. Dev Biol. 1996;178:179-185.

29. Bing $Y Z$, Hirao $Y$, Takenouchi N, et al. Effects of thioredoxin on the preimplantation development of bovine embryos. Theriogenology. 2003;59:863-873. 
30. Zhang DD. Mechanistic studies of the Nrf2-Keap1 signaling pathway. Drug Metab Rev. 2006;38:769-789.

31. Gladyshev VN, Liu A, Novoselov SV, et al. Identification and characterization of a new mammalian glutaredoxin (thioltransferase), Grx2. J Biol Chem. 2001;276:30374-30380.

32. De Matos DG, Furnus CC, Moses DF, Martinez AG, Matkovic M. Stimulation of Glutathione Synthesis of In Vitro Matured Bovine Oocytes and-ItsEffect on Embryo Development and Freezability. Mol Reprod Dev. 1996;45:451-457.

33. Gasparrini B, Sayoud H, Neglia G, De Matos DG, Donnay I, Zicarelli L. Glutathione synthesis during in vitro maturation of buffalo (Bubalus bubalis) oocytes: effects of cysteamine on embryo development. Theriogenology. 2003;60:943-952.

34. Zhang $\mathrm{H}, \mathrm{Du} Y$, Zhang $\mathrm{X}$, Lu J, Holmgren A. Glutaredoxin 2 reduces both thioredoxin 2 and thioredoxin 1 and protects cells from apoptosis induced by auranofin and 4-hydroxynonenal. Antioxid Redox Signal. 2014;21:669-681.

35. Kaplan KB, Li R. A prescription for 'stress' - the role of Hsp90 in genome stability and cellular adaptation. Trends Cell Biol. 2012;22:576-583.

36. Fang $Q$, Inanc $B$, Schamus $S$, et al. HSP90 regulates DNA repair via the interaction between XRCC1 and DNA polymerase $\beta$. Nat Commun. 2014;26:5513-5553.

37. Zuehlke AD, Beebe K, Neckers L, Prince T. Regulation and function of the human HSP90AA1 gene. Gene. 2015;570: 8-16.

38. Wrenzycki C, Niemann H. Epigenetic reprogramming in early embryonic development: effects of in-vitro production and somatic nuclear transfer. Reprod Biomed Online. 2003;7:649-656.

39. Ding L, Paszkowski-Rogacz M, Nitzsche A, et al. A genome-scale RNAi screen for Oct4 modulators defines a role of the Paf1 complex for embryonic stem cell identity. Cell stem cell. 2009;4:403-415.

40. Okano M, Xie S, Li E. Cloning and characterization of a family of novel mammalian DNA (cytosine5) methyltransferases. Nat Genet. 1998;19: 219-220.

41. Magenta A, Greco S, Gaetano C, Martelli F. Oxidative Stress and MicroRNAs in Vascular Diseases. Int J Mol Sci. 2013;14: 17319-17346.

42. Chan SY, Loscalzo J. MicroRNA-210: a unique and pleiotropic hypoxamir. Cell Cycle. 2010;9:107283.

43. Xiong $L$, Wang $F$, Huang $X$, et al. DNA demethylation regulates the expression of miR-210 in neural progenitor cells subjected to hypoxia. FEBS J. 2012;279:4318-4326.

44. Yamanaka K, Kaneda M, Inaba Y, et al. DNA methylation analysis on satellite I region in blastocysts obtained from somatic cell cloned cattle. Anim Sci J. 2011;82:523-530.

45. Biniszkiewicz D, Gribnau J, Ramsahoye B, et al. Dnmt1 overexpression causes genomic hypermethylation, loss of imprinting, and embryonic lethality. Mol Cell Biol. 2002;22:2124-2135. 
Supplementary Table S1. Relative expression of 31 mRNAs related with oxidative stress responses, cellular stress responses and epigenetic remodeling in eight biological replicates of bovine blastocysts cultured under high (20\%) or low (5\%) oxygen tensions.

\begin{tabular}{l|cc|cc}
\hline \multicolumn{2}{c}{ High $\mathrm{O}_{2}$} & \multicolumn{2}{c}{ Low $\mathrm{O}_{2}$} \\
\hline \multicolumn{1}{c}{ Genes } & Mean & SD & Mean & SD \\
\hline ATF4 & 0.0684 & 0.0235 & 0.0575 & 0.0119 \\
CAT & $0.0204^{\mathrm{a}}$ & 0.0040 & $0.0143^{\mathrm{b}}$ & 0.0032 \\
DDIT3 & 0.0067 & 0.0019 & 0.0075 & 0.0027 \\
DNMT1 & 0.0042 & 0.0015 & 0.0033 & 0.0016 \\
DNMT3A & $0.1587^{\mathrm{a}}$ & 0.0368 & $0.0992^{\mathrm{b}}$ & 0.0381 \\
DNMT3B & 0.0663 & 0.0193 & 0.0506 & 0.0174 \\
FOXO3 & 0.0035 & 0.0013 & 0.0032 & 0.0015 \\
GADD45A & 0.0090 & 0.0028 & 0.0071 & 0.0019 \\
GLRX2 & $0.0225^{\mathrm{a}}$ & 0.0051 & $0.0138^{\mathrm{b}}$ & 0.0026 \\
GPX1 & 0.1205 & 0.0302 & 0.1243 & 0.0176 \\
GPX4 & 0.0747 & 0.0241 & 0.0631 & 0.0132 \\
GRP78 & 0.1711 & 0.0283 & 0.1278 & 0.0565 \\
H2AFZ & $0.1475^{\mathrm{a}}$ & 0.0440 & $0.0876^{\mathrm{b}}$ & 0.0303 \\
H3F3B & $0.0080^{\mathrm{a}}$ & 0.0024 & $0.0053^{\mathrm{b}}$ & 0.0025 \\
HDAC2 & $0.0133^{\mathrm{a}}$ & 0.0030 & $0.0081^{\mathrm{b}}$ & 0.0021 \\
HIF1A & 0.0053 & 0.0022 & 0.0038 & 0.0017 \\
HSP9OAA1 & $0.6412^{\mathrm{a}}$ & 0.1272 & $0.4061^{\mathrm{b}}$ & 0.0510 \\
HSPA1A & 0.0078 & 0.0046 & 0.0091 & 0.0054 \\
IMPDH1 & 0.0085 & 0.0035 & 0.0067 & 0.0028 \\
KEAP1 & $0.0103^{\mathrm{a}}$ & 0.0020 & $0.0076^{\mathrm{b}}$ & 0.0027 \\
MORF4L2 & $0.0061^{\mathrm{a}}$ & 0.0014 & $0.0040^{\mathrm{b}}$ & 0.0016 \\
NRF2 & $0.0094^{\mathrm{a}}$ & 0.0029 & $0.0058^{\mathrm{b}}$ & 0.0015 \\
PAF1 & $0.0181^{\mathrm{a}}$ & 0.0037 & $0.0138^{\mathrm{b}}$ & 0.0043 \\
PRDX1 & $0.5321^{\mathrm{a}}$ & 0.0967 & $0.3912^{\mathrm{b}}$ & 0.0559 \\
PRDX3 & $0.0178^{\mathrm{a}}$ & 0.0023 & $0.0137^{\mathrm{b}}$ & 0.0035 \\
REST & $0.0048^{\mathrm{a}}$ & 0.0012 & $0.0033^{\mathrm{b}}$ & 0.0011 \\
SOD1 & $0.0380^{\mathrm{a}}$ & 0.0061 & $0.0264^{\mathrm{b}}$ & 0.0074 \\
SOD2 & 0.0222 & 0.0160 & 0.0162 & 0.0070 \\
TXN & $0.2684^{\mathrm{a}}$ & 0.0408 & $0.1961^{\mathrm{b}}$ & 0.0425 \\
TXNRD1 & $0.0418^{\mathrm{a}}$ & 0.0080 & $0.0315^{\mathrm{b}}$ & 0.0099 \\
XBP1 & 0.0310 & 0.0128 & 0.0218 & 0.0104 \\
\hline SD = Standard deviation & & & \\
Different letters within lines indicate & difference & $\mathrm{p} \leq 0,05)$.
\end{tabular}

